\title{
Chiral Bifunctional Phosphine Ligand Enables Gold-Catalyzed Asymmetric Isomerization and Cyclization of Propargyl Sulfonamide into Chiral 3- Pyrroline
}

\author{
Xinpeng Cheng and Liming Zhang*
}

Department of Chemistry and Biochemistry, University of California, Santa Barbara, California 93106, United States; E-mail: zhang@chem.ucsb.edu

\begin{tabular}{|l|c|}
\hline General Information & S2 \\
\hline Synthesis of Compounds 1 & S3 \\
\hline Synthesis of Compounds 2 & S38 \\
\hline Applications & S52 \\
\hline X-ray Structure of cis-2a & S56 \\
\hline References & S58 \\
\hline HPLC Spectrum & S59 \\
\hline${ }^{1}$ H, ${ }^{13}$ C, ${ }^{19}$ F and 2D NMR Spectrum & S65 \\
\hline
\end{tabular}




\section{General Information}

Ethyl acetate (ACS grade), hexanes (ACS grade), dichloromethane (ACS grade) were purchased from Fisher Scientific and used without further purification. ACS grade 1,2-dichloroethane was purchased from Acros Organics and used directly. Commercially available reagents were used without further purification. Reactions were monitored by thin-layer chromatography (TLC) using Silicycle precoated silica gel plates. Flash column chromatography was performed over Silicycle silica gel (230-400 mesh). ${ }^{1} \mathrm{H}$ NMR and ${ }^{13} \mathrm{C}$ NMR spectra were recorded on a Varian $400 \mathrm{MHz}$, $500 \mathrm{MHz}$ and $600 \mathrm{MHz}$ spectrometers using residue solvent peaks as internal standards $\left(\mathrm{CDCl}_{3}\right.$, ${ }^{1} \mathrm{H}: 7.26 \mathrm{ppm} ;{ }^{13} \mathrm{C}: 77.00 \mathrm{ppm} . \mathrm{CD}_{2} \mathrm{Cl}_{2},{ }^{1} \mathrm{H}: 5.32 \mathrm{ppm} ;{ }^{13} \mathrm{C}: 53.84 \mathrm{ppm}$ ) (multiplicity: s = singlet, $\mathrm{d}=$ doublet, $\mathrm{t}=$ triplet, $\mathrm{q}=$ quadruplet, quint $=$ quintuplet, sext $=$ sextuplet, sept $=$ septuplet, oct $=$ octuplet, non $=$ nonuplet, $\mathrm{m}=$ multiplet). ${ }^{31} \mathrm{P}$ NMR spectra were recorded on an Agilent $400 \mathrm{MHz}$ spectrometer calibrated by phosphoric acid peak $\left(\mathrm{H}_{3} \mathrm{PO}_{4},{ }^{31} \mathrm{P}: 0.00 \mathrm{ppm}\right) .{ }^{19} \mathrm{~F}$ NMR spectra were recorded on an Agilent $400 \mathrm{MHz}$ spectrometer calibrated by trifluoroacetic acid peak $\left(\mathrm{CF}_{3} \mathrm{COOH}\right.$, ${ }^{19} \mathrm{~F}$ : $\left.-76.55 \mathrm{ppm}\right)$. Mass spectra were recorded with Waters micro mass ZQ detector using the electrospray and time of flight. Kappa apex II diffractometer was used for crystal measurement.

$(S)-\mathbf{L} 1 \mathrm{AuCl}{ }^{1},(R)-\mathbf{L} \mathbf{A} \mathrm{AuCl}^{1},(R)-\mathbf{L} \mathbf{2} \mathrm{AuCl}^{2}$, and $\mathbf{L} \mathbf{3} \mathrm{AuCl}^{3}$ were synthesized according to our previously published work. 


\section{Synthesis of Compounds 1}

$N$-Sulfinyl imines $\mathbf{S 1}$ were synthesized from the condensation ${ }^{4-5}$ of aldehyde/ketone with chiral tert-butylsulfinamide.

\section{General Procedure A:}

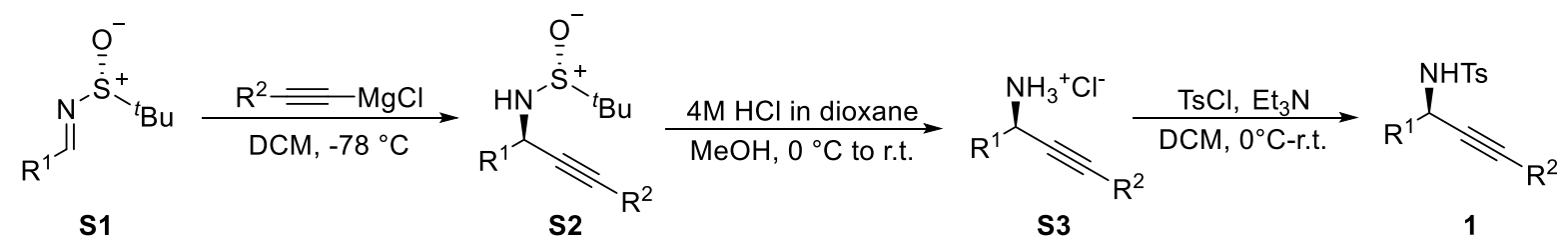

Compounds 1 was synthesized according to a modified literature procedure ${ }^{6}$.

Preparation of Alkynyl Grignard Reagents:

$$
\mathrm{R}^{2}=\mathrm{H} \underset{\mathrm{THF}, 0^{\circ} \mathrm{C}-\text { r.t., } 1 \mathrm{~h}}{\stackrel{i \mathrm{PrMCl}(2.0 \mathrm{M} \text { in } \mathrm{THF}}{\longrightarrow}} \mathrm{R}^{2} \equiv \mathrm{MgCl}
$$

To a solution of terminal alkynes ( $22 \mathrm{mmol}, 2.2$ equiv.) in $\mathrm{THF}(3 \mathrm{~mL})$ at $0{ }^{\circ} \mathrm{C}, 2 \mathrm{M} i \operatorname{Pr} \mathrm{MgCl}$ in THF (10 mL, $20 \mathrm{mmol}, 2.0$ equiv.) was added slowly, and gas evolution was observed during the process. The resulting solution was allowed to warm to room temperature and stirred for $60 \mathrm{~min}$ to afford the alkynyl Grignard solution.

Preparation of Compound $\mathbf{S 2}$ :

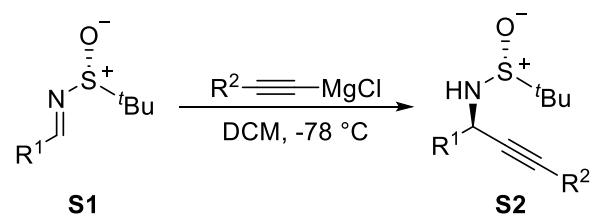

The freshly prepared alkynyl Grignard solution was slowly added into a solution of $N$-sulfinyl imine $\mathbf{S 1}$ (10 mmol, 1.0 equiv.) in $\mathrm{CH}_{2} \mathrm{Cl}_{2}(40 \mathrm{~mL})$ via cannula at $-78{ }^{\circ} \mathrm{C}$ under argon protection. The resulting solution was stirred at $-78{ }^{\circ} \mathrm{C}$ for $2 \mathrm{~h}$, then gradually warmed to room temperature and stirred overnight. The reaction was quenched by saturated $\mathrm{NH}_{4} \mathrm{Cl}$ solution, followed by extraction with EtOAc three times. The combined organic layer was washed with brine, dried over $\mathrm{Na}_{2} \mathrm{SO}_{4}$, and the combined organic layer was concentrated under reduced pressure. The residue was purified by silica gel flash column chromatography eluting with EtOAc/hexane to separate the diastereomers. 
Preparation of Compound $\mathbf{S 3}$

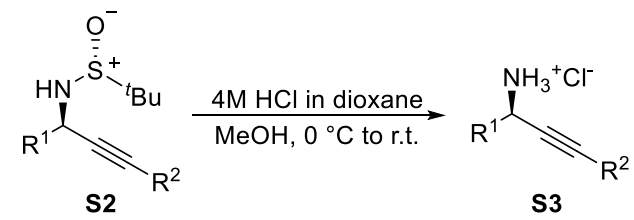

4M HCl solution in dioxane ( $4 \mathrm{mmol}, 1 \mathrm{~mL}, 4.0$ equiv.) was added into a solution of $\mathbf{S 2}$ ( $1 \mathrm{mmol})$ in $\mathrm{MeOH}(5 \mathrm{~mL})$. The reaction mixture was stirred at room temperature for $30 \mathrm{~min}$. The solvent was removed under reduced pressure to afford crude product S3, which was directly used in the next step without further purification.

Synthesis of Compound 1

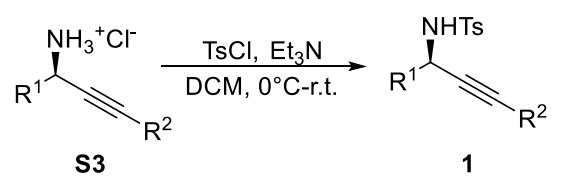

Crude product $\mathbf{S 3}(1 \mathrm{mmol})$ was dissolved in $5 \mathrm{~mL} \mathrm{CH}_{2} \mathrm{Cl}_{2}$ at $0{ }^{\circ} \mathrm{C}$, followed by the addition of $\mathrm{Et}_{3} \mathrm{~N}$ (0.42 mL, $3 \mathrm{mmol}, 3$ equiv.) and $\mathrm{TsCl}$ (229 mg, $1.2 \mathrm{mmol}, 1.2$ equiv.). The resulting mixture was allowed to warm to room temperature and stirred overnight. The reaction was quenched with saturated $\mathrm{NH}_{4} \mathrm{Cl}$ solution, and extracted by $\mathrm{CH}_{2} \mathrm{Cl}_{2}$ three times. The combined organic layer was washed with brine, dried over $\mathrm{Na}_{2} \mathrm{SO}_{4}$, and concentrated under reduced pressure. The residue was purified by silica gel flash column chromatography eluting with EtOAc/hexane to afford a lightyellow solid. The product was further purified by recrystallization from hexane to afford a white needle compound $\mathbf{1}$.

(R)-4-Methyl- $N$-(oct-3-yn-2-yl)benzenesulfonamide (1a)

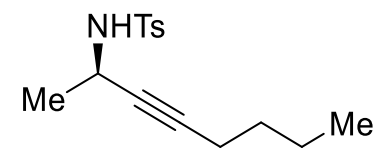

$1 \mathbf{a}$

Compound 1a was synthesized according to General Procedure A. 


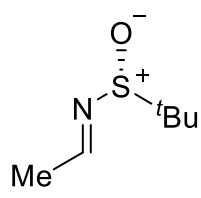

s1

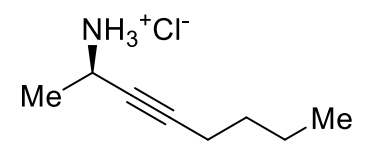

S3a

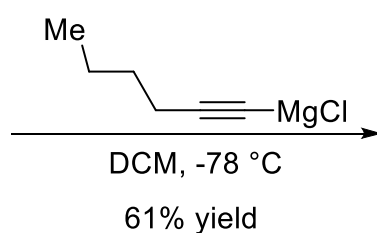

$61 \%$ yield

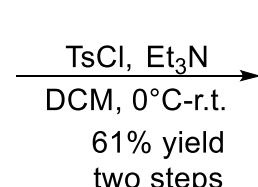

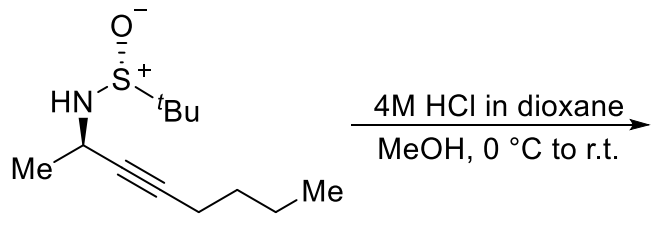

S2a

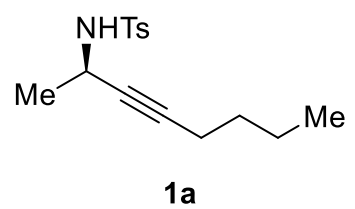

To a solution of 1-hexyne (4.36 mL, $38 \mathrm{mmol}, 2.2$ equiv.) in $\mathrm{THF}(5 \mathrm{~mL})$ at $0{ }^{\circ} \mathrm{C}, 2 \mathrm{M} i \operatorname{Pr} \mathrm{MgCl}$ in THF (17.3 mL, $34.5 \mathrm{mmol}, 2.0$ equiv.) was added slowly. The resulting solution was allowed to warm to room temperature and stirred for $60 \mathrm{~min}$ to afford the 1-hexynyl magnesium chloride solution.

The freshly prepared 1-hexynyl magnesium chloride solution was slowly added into a solution of $N$-sulfinyl imine $\mathbf{S 1}$ (2.53 g, $17.2 \mathrm{mmol}, 1.0$ equiv.) in $\mathrm{CH}_{2} \mathrm{Cl}_{2}(70 \mathrm{~mL})$ via cannula at $-78^{\circ} \mathrm{C}$ under argon protection. The resulting solution was stirred at $-78{ }^{\circ} \mathrm{C}$ for $2 \mathrm{~h}$, then gradually warmed to room temperature and stirred overnight. The reaction was quenched by saturated $\mathrm{NH}_{4} \mathrm{Cl}$ solution, followed by extraction with EtOAc three times. The combined organic layer was washed with brine, dried over $\mathrm{Na}_{2} \mathrm{SO}_{4}$, and the combined organic layer was concentrated under reduced pressure. The residue was purified by silica gel flash column chromatography (hexane/EtOAc $=3 / 1-2 / 1$ ) to afford S2a (2.41 g, $10.5 \mathrm{mmol}, 61 \%$ yield) as a colorless oil.

4M HCl solution in dioxane ( $4 \mathrm{mmol}, 1 \mathrm{~mL}, 4.0$ equiv.) was added into a solution of $\mathbf{S 2 a}$ (229.5 $\mathrm{mg}, 1 \mathrm{mmol})$ in $\mathrm{MeOH}(5 \mathrm{~mL})$. The reaction mixture was stirred at room temperature for $30 \mathrm{~min}$. The solvent was removed under reduced pressure to afford crude product S3a, which was directly used in the next step without further purification. Crude product $\mathbf{S 3 a}$ was dissolved in $5 \mathrm{~mL} \mathrm{CH}_{2} \mathrm{Cl}_{2}$ at $0{ }^{\circ} \mathrm{C}$, followed by the addition of $\mathrm{Et}_{3} \mathrm{~N}(0.42 \mathrm{~mL}, 3 \mathrm{mmol}, 3$ equiv. $)$ and $\mathrm{TsCl}(229 \mathrm{mg}, 1.2 \mathrm{mmol}$, 1.2 equiv.). The resulting mixture was allowed to warm to room temperature and stirred overnight. The reaction was quenched with saturated $\mathrm{NH}_{4} \mathrm{Cl}$ solution and extracted by $\mathrm{CH}_{2} \mathrm{Cl}_{2}$ three times. The combined organic layer was washed with brine, dried over $\mathrm{Na}_{2} \mathrm{SO}_{4}$, and concentrated under reduced pressure. The residue was purified by silica gel flash column chromatography 
(hexane/EtOAc $=10 / 1)$ to afford a light-yellow solid. The product was further purified by recrystallization from hexane to afford $1 \mathbf{a}(170.2 \mathrm{mg}, 0.61 \mathrm{mmol})$ as a white needle.

${ }^{1}$ H NMR (600 MHz, CDCl $) \delta 7.77(\mathrm{~d}, J=8.3 \mathrm{~Hz}, 2 \mathrm{H}), 7.29(\mathrm{~d}, J=8.0 \mathrm{~Hz}, 2 \mathrm{H}), 4.52(\mathrm{~d}, J=8.9$ $\mathrm{Hz}, 1 \mathrm{H}), 4.15(\mathrm{dqt}, J=8.9,6.9,2.1 \mathrm{~Hz}, 1 \mathrm{H}), 2.42(\mathrm{~s}, 3 \mathrm{H}), 1.92-1.86(\mathrm{~m}, 2 \mathrm{H}), 1.37$ (d, $J=6.9 \mathrm{~Hz}$, 3H), $1.28-1.19$ (m, 4H), $0.88-0.81$ (m, 3H). ${ }^{13} \mathbf{C}$ NMR (126 MHz, CDCl3) $\delta$ 143.2, 137.6, 129.4, 127.4, 84.3, 79.1, 41.7, 30.4, 24.0, 21.8, 21.5, 18.0, 13.5. HRMS (ESI) $m / z:[\mathrm{M}+\mathrm{Na}]^{+}$calcd for $\mathrm{C}_{15} \mathrm{H}_{21} \mathrm{NO}_{2} \mathrm{SNa}$ 302.1191; Found $\mathrm{m} / z$ 302.1198. 99.8\% e e HPLC (IC, Hexane/iPrOH = 90/10, flow rate $=1.0 \mathrm{~mL} / \mathrm{min}, \lambda=202 \mathrm{~nm}$ ) $t_{R}=19.13 \mathrm{~min}$ (major), $t_{R}=15.55 \mathrm{~min}$ (minor).

\section{(R)-4-Methyl- $N$-(6-phenylhex-3-yn-2-yl)benzenesulfonamide (1b)}

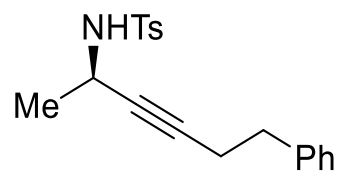

$1 b$

Compound $\mathbf{1 b}$ was synthesized according to General Procedure A.

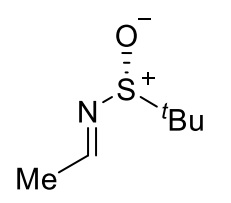

S1
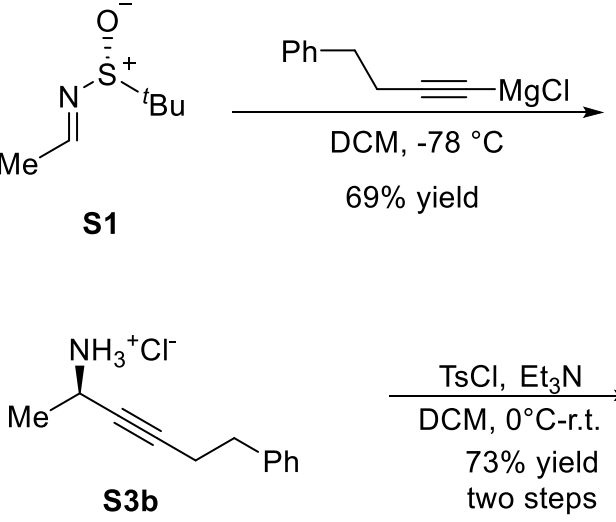
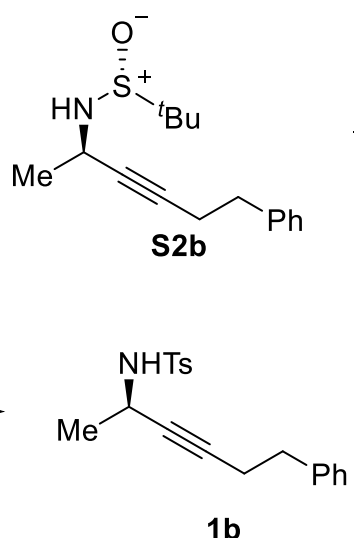

To a solution of 4-phenyl-1-butyne $(1.55 \mathrm{~mL}, 11 \mathrm{mmol}, 2.2$ equiv. $)$ in THF $(1.5 \mathrm{~mL})$ at $0{ }^{\circ} \mathrm{C}, 2 \mathrm{M}$ $i \operatorname{Pr} \mathrm{MgCl}$ in THF (5 mL, $10 \mathrm{mmol}, 2.0$ equiv.) was added slowly. The resulting solution was allowed to warm to room temperature and stirred for $60 \mathrm{~min}$ to afford the 4-phenyl-1-butynyl magnesium chloride solution.

The freshly prepared 4-phenyl-1-butynyl magnesium chloride solution was slowly added into a solution of $N$-sulfinyl imine $\mathbf{S 1}$ (736.2 $\mathrm{mg}, 5 \mathrm{mmol}, 1.0$ equiv.) in $\mathrm{CH}_{2} \mathrm{Cl}_{2}(20 \mathrm{~mL})$ via cannula at 
$-78{ }^{\circ} \mathrm{C}$ under argon protection. The resulting solution was stirred at $-78{ }^{\circ} \mathrm{C}$ for $2 \mathrm{~h}$, then gradually warmed to room temperature and stirred overnight. The reaction was quenched by saturated $\mathrm{NH}_{4} \mathrm{Cl}$ solution, followed by extraction with EtOAc three times. The combined organic layer was washed with brine, dried over $\mathrm{Na}_{2} \mathrm{SO}_{4}$, and the combined organic layer was concentrated under reduced pressure. The residue was purified by silica gel flash column chromatography (hexane/EtOAc = 3/1-2/1) to afford S2b (951 mg, $3.43 \mathrm{mmol}, 69 \%$ yield) as a colorless oil.

4M HCl solution in dioxane (13.6 mmol, $3.4 \mathrm{~mL}, 4.0$ equiv.) was added into a solution of $\mathbf{S 2 b}$ (951 mg, $3.43 \mathrm{mmol})$ in $\mathrm{MeOH}(17 \mathrm{~mL})$. The reaction mixture was stirred at room temperature for $30 \mathrm{~min}$. The solvent was removed under reduced pressure to afford crude product $\mathbf{S 3 b}$, which was directly used in the next step without further purification. Crude product $\mathbf{S 3 b}$ was dissolved in 15 $\mathrm{mL} \mathrm{CH}_{2} \mathrm{Cl}_{2}$ at $0{ }^{\circ} \mathrm{C}$, followed by the addition of $\mathrm{Et}_{3} \mathrm{~N}$ (2.41 mL, $17 \mathrm{mmol}, 5$ equiv.) and $\mathrm{TsCl}(785$ $\mathrm{mg}, 4.11 \mathrm{mmol}, 1.2$ equiv.). The resulting mixture was allowed to warm to room temperature and stirred overnight. The reaction was quenched with saturated $\mathrm{NH}_{4} \mathrm{Cl}$ solution and extracted by $\mathrm{CH}_{2} \mathrm{Cl}_{2}$ three times. The combined organic layer was washed with brine, dried over $\mathrm{Na}_{2} \mathrm{SO}_{4}$, and concentrated under reduced pressure. The residue was purified by silica gel flash column chromatography (hexane/EtOAc $=10 / 1)$ to afford a light-yellow solid. The product was further purified by recrystallization from hexane to afford $\mathbf{1 b}(821.5 \mathrm{mg}, 2.51 \mathrm{mmol}, 74 \%$ yield $)$ as a white needle.

${ }^{1}$ H NMR (600 MHz, CDCl $) \delta 7.75(\mathrm{~d}, J=8.3 \mathrm{~Hz}, 2 \mathrm{H}), 7.32-7.24$ (m, 4H), $7.24-7.18$ (m, 1H), $7.10(\mathrm{~d}, J=8.4 \mathrm{~Hz}, 2 \mathrm{H}), 4.59(\mathrm{~d}, J=8.6 \mathrm{~Hz}, 1 \mathrm{H}), 4.14(\mathrm{ddt}, J=8.8,6.8,2.0 \mathrm{~Hz}, 1 \mathrm{H}), 2.56(\mathrm{t}, J=$ $7.6 \mathrm{~Hz}, 2 \mathrm{H}), 2.40(\mathrm{~s}, 3 \mathrm{H}), 2.17(\mathrm{tt}, J=7.6,1.8 \mathrm{~Hz}, 2 \mathrm{H}), 1.36(\mathrm{~d}, J=6.9 \mathrm{~Hz}, 3 \mathrm{H}) .{ }^{13} \mathrm{C}$ NMR (101 MHz, CDCl $) \delta 143.3,140.4,137.4,129.4,128.3,128.3,127.4,126.3,83.5,79.9,41.6,34.7,23.7$, 21.5, 20.6. HRMS (ESI) $m / z:[\mathrm{M}+\mathrm{Na}]^{+}$calcd for $\mathrm{C}_{19} \mathrm{H}_{21} \mathrm{NO}_{2} \mathrm{SNa} 350.1191$; Found $m / z$ 350.1184. (R)-4-Methyl-N-(6-methylhept-3-yn-2-yl)benzenesulfonamide (1c)

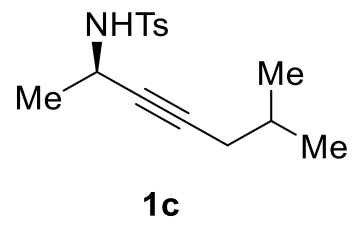

Compound 1c was synthesized according to General Procedure A. 


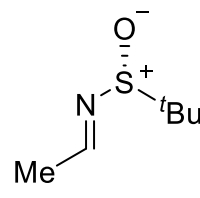

S1

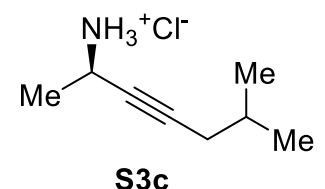

S3c

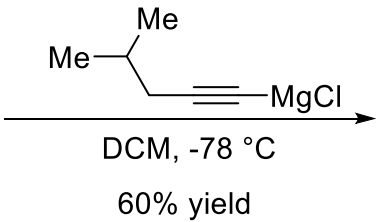

$60 \%$ yield

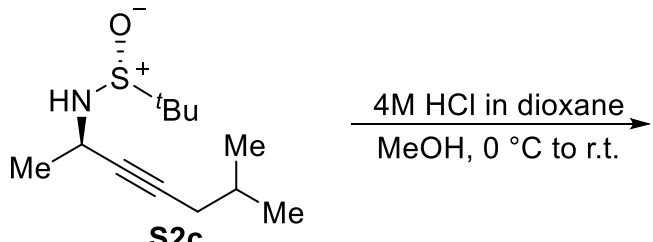

S2c

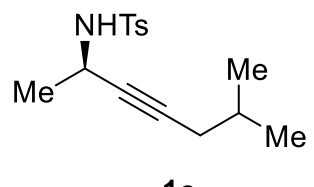

1c

To a solution of 4-methyl-1-pentyne $\left(1.29 \mathrm{~mL}, 11 \mathrm{mmol}, 2.2\right.$ equiv.) in THF $(1.5 \mathrm{~mL})$ at $0{ }^{\circ} \mathrm{C}, 2 \mathrm{M}$ $i \operatorname{Pr} \mathrm{MgCl}$ in THF (5 mL, $10 \mathrm{mmol}, 2.0$ equiv.) was added slowly. The resulting solution was allowed to warm to room temperature and stirred for $60 \mathrm{~min}$ to afford the 4-methyl-1-pentynyl magnesium chloride solution.

The freshly prepared 4-methyl-1-pentynyl magnesium chloride solution was slowly added into a solution of $N$-sulfinyl imine $\mathbf{S 1}$ (736.2 mg, $5 \mathrm{mmol}, 1.0$ equiv.) in $\mathrm{CH}_{2} \mathrm{Cl}_{2}$ (20 mL) via cannula at $-78{ }^{\circ} \mathrm{C}$ under argon protection. The resulting solution was stirred at $-78{ }^{\circ} \mathrm{C}$ for $2 \mathrm{~h}$, then gradually warmed to room temperature and stirred overnight. The reaction was quenched by saturated $\mathrm{NH}_{4} \mathrm{Cl}$ solution, followed by extraction with EtOAc three times. The combined organic layer was washed with brine, dried over $\mathrm{Na}_{2} \mathrm{SO}_{4}$, and the combined organic layer was concentrated under reduced pressure. The residue was purified by silica gel flash column chromatography (hexane/EtOAc $=$ 3/1) to afford S2c (687.4 $\mathrm{mg}, 3.00 \mathrm{mmol}, 60 \%$ yield) as a colorless oil.

4M HCl solution in dioxane (12.0 mmol, $3.0 \mathrm{~mL}, 4.0$ equiv.) was added into a solution of S2c (687.4 mg, $3.00 \mathrm{mmol})$ in $\mathrm{MeOH}(15 \mathrm{~mL})$. The reaction mixture was stirred at room temperature for $30 \mathrm{~min}$. The solvent was removed under reduced pressure to afford crude product $\mathbf{S 3 c}$, which was directly used in the next step without further purification. Crude product S3c was dissolved in $15 \mathrm{~mL} \mathrm{CH}_{2} \mathrm{Cl}_{2}$ at $0{ }^{\circ} \mathrm{C}$, followed by the addition of $\mathrm{Et}_{3} \mathrm{~N}$ (2.11 mL, $15 \mathrm{mmol}, 5$ equiv.) and TsCl (686.3 $\mathrm{mg}, 3.60 \mathrm{mmol}, 1.2$ equiv.). The resulting mixture was allowed to warm to room temperature and stirred overnight. The reaction was quenched with saturated $\mathrm{NH}_{4} \mathrm{Cl}$ solution and extracted by $\mathrm{CH}_{2} \mathrm{Cl}_{2}$ three times. The combined organic layer was washed with brine, dried over $\mathrm{Na}_{2} \mathrm{SO}_{4}$, and concentrated under reduced pressure. The residue was purified by silica gel flash column chromatography (hexane/EtOAc $=10 / 1$ ) to afford a light-yellow solid. The product was 
further purified by recrystallization from hexane to afford $1 \mathrm{c}(520.2 \mathrm{mg}, 1.86 \mathrm{mmol}, 62 \%$ yield) as a white needle.

${ }^{1}$ H NMR (500 MHz, CDCl $) \delta 7.77(\mathrm{~d}, J=8.3 \mathrm{~Hz}, 2 \mathrm{H}), 7.28(\mathrm{~d}, J=8.0 \mathrm{~Hz}, 2 \mathrm{H}), 4.61(\mathrm{~d}, J=8.7$ $\mathrm{Hz}, 1 \mathrm{H}), 4.16(\mathrm{dqt}, J=8.9,6.9,2.1 \mathrm{~Hz}, 1 \mathrm{H}), 2.41(\mathrm{~s}, 3 \mathrm{H}), 1.78(\mathrm{dd}, J=6.6,2.1 \mathrm{~Hz}, 2 \mathrm{H}), 1.54$ (non, $J=6.7 \mathrm{~Hz}, 1 \mathrm{H}), 1.38(\mathrm{~d}, J=6.9 \mathrm{~Hz}, 3 \mathrm{H}), 0.80(\mathrm{~d}, J=6.7 \mathrm{~Hz}, 6 \mathrm{H}) .{ }^{13} \mathbf{C} \mathbf{~ N M R}(\mathbf{1 2 6} \mathbf{M H z}, \mathbf{C D C l})$ $\delta 143.2,137.5,129.4,127.4,83.2,80.0,41.7,27.7,27.5,24.0,21.8,21.5$. HRMS (ESI) $\mathrm{m} / \mathrm{z}$ : $[\mathrm{M}+\mathrm{Na}]^{+}$calcd for $\mathrm{C}_{15} \mathrm{H}_{21} \mathrm{NO}_{2} \mathrm{SNa}$ 302.1191; Found $\mathrm{m} / z$ 350.1192.

(R)-N-(5-cyclohexylpent-3-yn-2-yl)-4-Methylbenzenesulfonamide (1d)

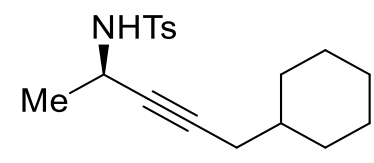

$1 d$

Compound 1d was synthesized according to General Procedure A.

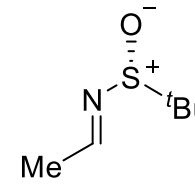

S1

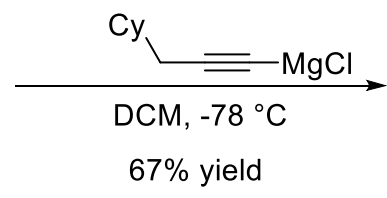<smiles>C[C@H](N)C#CC[AlH2]</smiles>

S3d

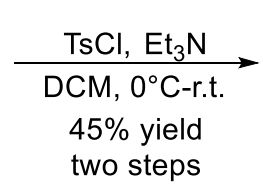

two steps
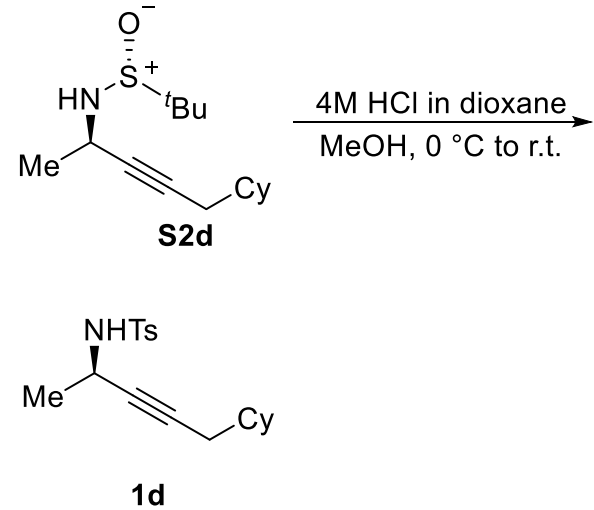

To a solution of 3-cyclohexyl-1-propyne $(1.60 \mathrm{~mL}, 11 \mathrm{mmol}, 2.2$ equiv. $)$ in THF $(1.5 \mathrm{~mL})$ at $0{ }^{\circ} \mathrm{C}$, $2 \mathrm{M} i \operatorname{Pr} \mathrm{MgCl}$ in THF (5 mL, $10 \mathrm{mmol}, 2.0$ equiv.) was added slowly. The resulting solution was allowed to warm to room temperature and stirred for $60 \mathrm{~min}$ to afford the 3-cyclohexyl-1-propynyl magnesium chloride solution.

The freshly prepared 3-cyclohexyl-1-propynyl magnesium chloride solution was slowly added into a solution of $N$-sulfinyl imine $\mathbf{S 1}$ (736.2 $\mathrm{mg}, 5 \mathrm{mmol}, 1.0$ equiv.) in $\mathrm{CH}_{2} \mathrm{Cl}_{2}(20 \mathrm{~mL})$ via cannula at $-78{ }^{\circ} \mathrm{C}$ under argon protection. The resulting solution was stirred at $-78{ }^{\circ} \mathrm{C}$ for $2 \mathrm{~h}$, then gradually warmed to room temperature and stirred overnight. The reaction was quenched by saturated $\mathrm{NH}_{4} \mathrm{Cl}$ 
solution, followed by extraction with EtOAc three times. The combined organic layer was washed with brine, dried over $\mathrm{Na}_{2} \mathrm{SO}_{4}$, and the combined organic layer was concentrated under reduced pressure. The residue was purified by silica gel flash column chromatography (hexane/EtOAc = 3/1) to afford $\mathbf{S 2 d}$ (904.1 $\mathrm{mg}, 3.36 \mathrm{mmol}, 67 \%$ yield) as a colorless oil.

4M HCl solution in dioxane (11.2 mmol, $2.8 \mathrm{~mL}, 4.0$ equiv.) was added into a solution of $\mathbf{S 2 d}$ (754.5 mg, $2.80 \mathrm{mmol})$ in $\mathrm{MeOH}(14 \mathrm{~mL})$. The reaction mixture was stirred at room temperature for $30 \mathrm{~min}$. The solvent was removed under reduced pressure to afford crude product S3d, which was directly used in the next step without further purification. Crude product S3d was dissolved in $15 \mathrm{~mL} \mathrm{CH}_{2} \mathrm{Cl}_{2}$ at $0{ }^{\circ} \mathrm{C}$, followed by the addition of $\mathrm{Et}_{3} \mathrm{~N}(1.20 \mathrm{~mL}, 8.6 \mathrm{mmol}, 3$ equiv. $)$ and $\mathrm{TsCl}$ (640.5 mg, $3.36 \mathrm{mmol}, 1.2$ equiv.). The resulting mixture was allowed to warm to room temperature and stirred overnight. The reaction was quenched with saturated $\mathrm{NH}_{4} \mathrm{Cl}$ solution and extracted by $\mathrm{CH}_{2} \mathrm{Cl}_{2}$ three times. The combined organic layer was washed with brine, dried over $\mathrm{Na}_{2} \mathrm{SO}_{4}$, and concentrated under reduced pressure. The residue was purified by silica gel flash column chromatography (hexane/EtOAc $=10 / 1$ ) to afford a light-yellow solid. The product was further purified by recrystallization from hexane to afford $\mathbf{1 d}(399.0 \mathrm{mg}, 1.25 \mathrm{mmol}, 45 \%$ yield $)$ as a white needle.

${ }^{1}$ H NMR (600 MHz, CDCl 3$) \delta 7.77(\mathrm{~d}, J=8.3 \mathrm{~Hz}, 2 \mathrm{H}), 7.29(\mathrm{~d}, J=8.0 \mathrm{~Hz}, 2 \mathrm{H}), 4.58(\mathrm{~d}, J=8.6$ $\mathrm{Hz}, 1 \mathrm{H}), 4.16(\mathrm{dqt}, J=8.9,6.9,2.1 \mathrm{~Hz}, 1 \mathrm{H}), 2.42$ (s, 3H), $1.78(\mathrm{dd}, J=6.7,2.1 \mathrm{~Hz}, 2 \mathrm{H}), 1.70-$ $1.56(\mathrm{~m}, 5 \mathrm{H}), 1.38(\mathrm{~d}, J=6.9 \mathrm{~Hz}, 3 \mathrm{H}), 1.23-1.12(\mathrm{~m}, 3 \mathrm{H}), 1.06(\mathrm{qt}, J=12.8,3.4 \mathrm{~Hz}, 1 \mathrm{H}), 0.79$ (qd, $J=12.5,3.3 \mathrm{~Hz}, 2 \mathrm{H}) .{ }^{13} \mathbf{C}$ NMR (101 MHz, CDCl3) $\delta 143.2,137.5,129.4,127.4,83.2,79.9$, $41.7,36.9,32.5,26.2,26.1,26.0,24.0,21.5$. HRMS (ESI) $m / z:[\mathrm{M}+\mathrm{Na}]^{+}$calcd for $\mathrm{C}_{18} \mathrm{H}_{25} \mathrm{NO}_{2} \mathrm{SNa}$ ) 342.1504; Found $m / z$ 342.1508. 99.3\% ee; HPLC (IC, Hexane/iPrOH $=90 / 10$, flow rate $=1.0$ $\mathrm{mL} / \mathrm{min}, \lambda=205 \mathrm{~nm}$ ) $t_{\mathrm{R}}=23.57 \mathrm{~min}$ (major), $t_{\mathrm{R}}=18.45 \mathrm{~min}$ (minor)

\section{(R)- $N$-(7-chlorohept-3-yn-2-yl)-4-Methylbenzenesulfonamide (1e)}

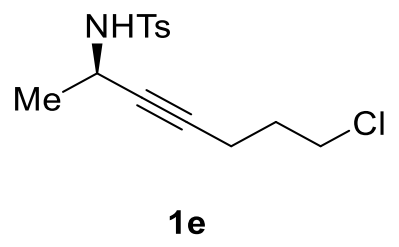

Compound 1e was synthesized according to General Procedure A. 


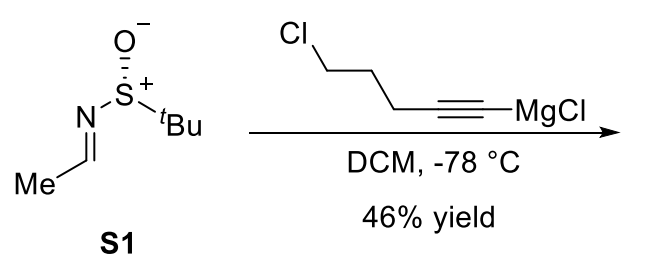

S1

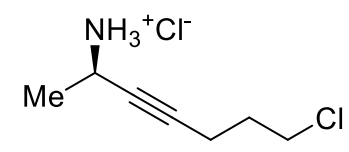

S3e

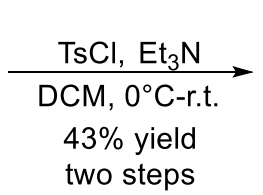

two steps
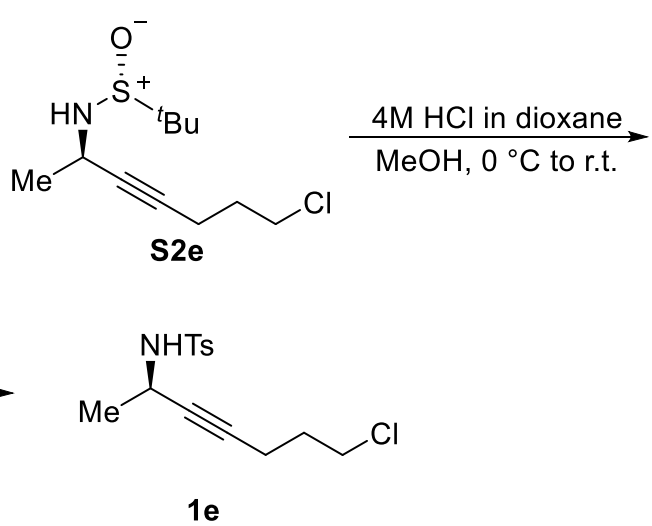

To a solution of 5-chloro-1-pentyne $\left(1.16 \mathrm{~mL}, 11 \mathrm{mmol}, 2.2\right.$ equiv.) in THF $(1.5 \mathrm{~mL})$ at $0{ }^{\circ} \mathrm{C}, 2 \mathrm{M}$ $i \operatorname{Pr} \mathrm{MgCl}$ in THF (5 mL, $10 \mathrm{mmol}, 2.0$ equiv.) was added slowly. The resulting solution was allowed to warm to room temperature and stirred for $60 \mathrm{~min}$ to afford the 5-chloro-1-pentynyl magnesium chloride solution.

The freshly prepared 5-chloro-1-pentynyl magnesium chloride solution was slowly added into a solution of $N$-sulfinyl imine $\mathbf{S 1}$ (736.2 mg, $5 \mathrm{mmol}, 1.0$ equiv.) in $\mathrm{CH}_{2} \mathrm{Cl}_{2}$ (20 mL) via cannula at $-78{ }^{\circ} \mathrm{C}$ under argon protection. The resulting solution was stirred at $-78{ }^{\circ} \mathrm{C}$ for $2 \mathrm{~h}$, then gradually warmed to room temperature and stirred overnight. The reaction was quenched by saturated $\mathrm{NH}_{4} \mathrm{Cl}$ solution, followed by extraction with EtOAc three times. The combined organic layer was washed with brine, dried over $\mathrm{Na}_{2} \mathrm{SO}_{4}$, and the combined organic layer was concentrated under reduced pressure. The residue was purified by silica gel flash column chromatography (hexane/EtOAc $=$ 3/1) to afford $\mathbf{S 2 e}$ (580.7 $\mathrm{mg}, 2.32 \mathrm{mmol}, 46 \%$ yield) as a colorless oil.

4M HCl solution in dioxane (9.2 mmol, $2.3 \mathrm{~mL}, 4.0$ equiv.) was added into a solution of $\mathbf{S 2 e}$ (580.7 $\mathrm{mg}, 2.32 \mathrm{mmol})$ in $\mathrm{MeOH}(12 \mathrm{~mL})$. The reaction mixture was stirred at room temperature for 30 min. The solvent was removed under reduced pressure to afford crude product $\mathbf{S 3 e}$, which was directly used in the next step without further purification. Crude product S3e was dissolved in 15 $\mathrm{mL} \mathrm{CH}_{2} \mathrm{Cl}_{2}$ at $0{ }^{\circ} \mathrm{C}$, followed by the addition of $\mathrm{Et}_{3} \mathrm{~N}$ (1.62 mL, $11.6 \mathrm{mmol}, 5$ equiv.) and $\mathrm{TsCl}$ (442.0 mg, $2.32 \mathrm{mmol}, 1.0$ equiv.). The resulting mixture was allowed to warm to room temperature and stirred overnight. The reaction was quenched with saturated $\mathrm{NH}_{4} \mathrm{Cl}$ solution and extracted by $\mathrm{CH}_{2} \mathrm{Cl}_{2}$ three times. The combined organic layer was washed with brine, dried over $\mathrm{Na}_{2} \mathrm{SO}_{4}$, and concentrated under reduced pressure. The residue was purified by silica gel flash column chromatography (hexane/EtOAc $=10 / 1$ ) to afford a light-yellow solid. The product was 
further purified by recrystallization from hexane to afford 1e (294.7 $\mathrm{mg}, 0.99 \mathrm{mmol}, 43 \%$ yield) as a white needle.

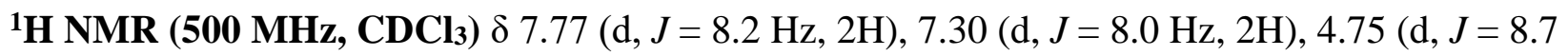
$\mathrm{Hz}, 1 \mathrm{H}), 4.15(\mathrm{dqt}, J=8.8,6.8,2.1 \mathrm{~Hz}, 1 \mathrm{H}), 3.41(\mathrm{t}, J=6.4 \mathrm{~Hz}, 2 \mathrm{H}), 2.42(\mathrm{~s}, 3 \mathrm{H}), 2.08(\mathrm{td}, J=$ 6.9, 2.1 Hz, 2H), 1.69 (p, $J=6.6 \mathrm{~Hz}, 2 \mathrm{H}), 1.37(\mathrm{~d}, J=6.9 \mathrm{~Hz}, 3 \mathrm{H}) .{ }^{13} \mathbf{C}$ NMR (126 MHz, CDCl$)$ $\delta 143.4,137.5,129.5,127.4,82.2,80.2,43.4,41.5,31.0,23.7,21.5,15.8$. HRMS (ESI) $m / z$ : $[\mathrm{M}+\mathrm{Na}]^{+}$calcd for $\mathrm{C}_{14} \mathrm{H}_{18} \mathrm{ClNO}_{2} \mathrm{SNa} 322.0645$; Found $\mathrm{m} / \mathrm{z} 322.0644$.

(R)-N-(6-((tert-butyldiphenylsilyl)oxy)hex-3-yn-2-yl)-4-Methylbenzenesulfonamide (1f)

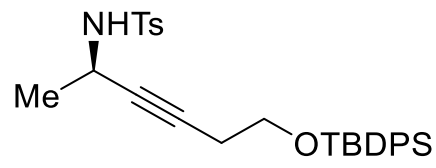

$1 f$

Compound 1f was synthesized according to General Procedure A and a modified literature procedure $^{7}$.

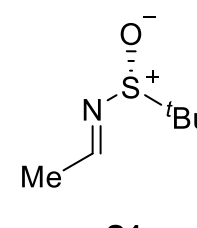

S1
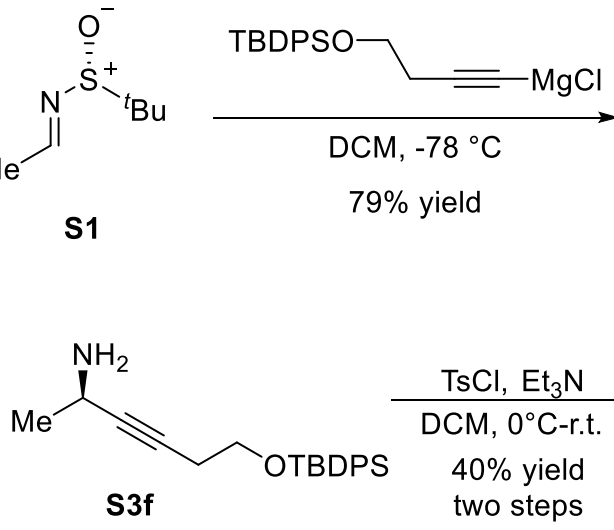
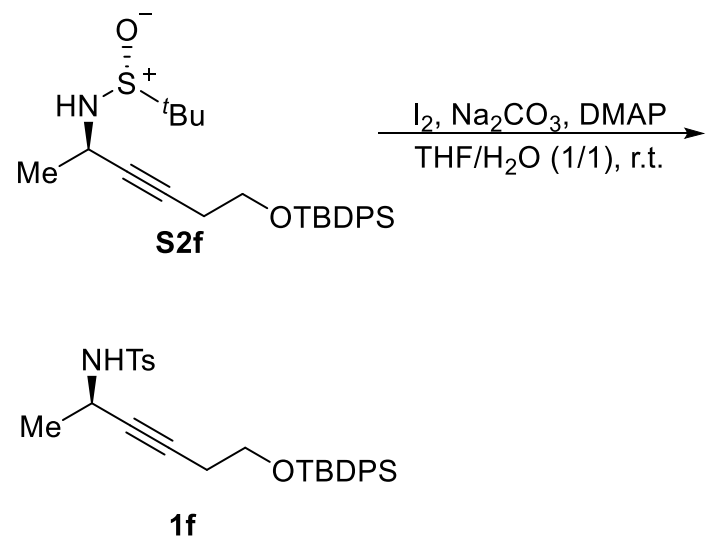

To a solution of tert-butyl(3-butynyloxy)diphenylsilane (3.39 g, $11 \mathrm{mmol}, 2.2$ equiv.) in THF (1.5 $\mathrm{mL}$ ) at $0{ }^{\circ} \mathrm{C}, 2 \mathrm{M} i \operatorname{Pr} \mathrm{MgCl}$ in THF (5 mL, $10 \mathrm{mmol}, 2.0$ equiv.) was added slowly. The resulting solution was allowed to warm to room temperature and stirred for $60 \mathrm{~min}$ to afford the alkynyl magnesium chloride solution. 
The freshly prepared alkynyl magnesium chloride solution was slowly added into a solution of $N$ sulfinyl imine $\mathbf{S 1}$ (736.2 mg, $5 \mathrm{mmol}, 1.0$ equiv.) in $\mathrm{CH}_{2} \mathrm{Cl}_{2}(20 \mathrm{~mL})$ via cannula at $-78{ }^{\circ} \mathrm{C}$ under argon protection. The resulting solution was stirred at $-78{ }^{\circ} \mathrm{C}$ for $2 \mathrm{~h}$, then gradually warmed to room temperature and stirred overnight. The reaction was quenched by saturated $\mathrm{NH}_{4} \mathrm{Cl}$ solution, followed by extraction with EtOAc three times. The combined organic layer was washed with brine, dried over $\mathrm{Na}_{2} \mathrm{SO}_{4}$, and the combined organic layer was concentrated under reduced pressure. The residue was purified by silica gel flash column chromatography (hexane/EtOAc $=3 / 1$ ) to afford S2f (1.8075 mg, $3.97 \mathrm{mmol}, 79 \%$ yield) as a colorless oil.

To a solution of $\mathbf{S 2 f}(1.5659 \mathrm{~g}, 3.1 \mathrm{mmol})$ in $\mathrm{THF} / \mathrm{H}_{2} \mathrm{O}(1: 1,60 \mathrm{~mL})$ was added $\mathrm{Na}_{2} \mathrm{CO}_{3}(996 \mathrm{mg}$, $3.9 \mathrm{mmol})$ and DMAP $(75.7 \mathrm{mg}, 0.62 \mathrm{mmol})$. The reaction mixture was stirred for $5 \mathrm{~min}$ at room temperature before the addition of $\mathrm{I}_{2}(1.9670 \mathrm{~g}, 7.75 \mathrm{mmol})$ under an argon atmosphere. The resulting mixture was then stirred at room temperature under argon for $24 \mathrm{~h}$. After consuming starting materials, the reaction was quenched by water and aqueous sodium thiosulphate at room temperature. The mixture was extracted with ethyl acetate three times. The combined organic phases were dried over $\mathrm{Na}_{2} \mathrm{SO}_{4}$, and concentrated under reduced pressure. Crude product $\mathbf{S 3 f}$ was dissolved in $18 \mathrm{~mL} \mathrm{CH}_{2} \mathrm{Cl}_{2}$ at $0{ }^{\circ} \mathrm{C}$, followed by the addition of $\mathrm{Et}_{3} \mathrm{~N}$ (2.50 mL, $17.9 \mathrm{mmol}, 5.8$ equiv.) and $\mathrm{TsCl}$ (686.3 mg, $2.32 \mathrm{mmol}, 1.16$ equiv.). The resulting mixture was allowed to warm to room temperature and stirred overnight. The reaction was quenched with saturated $\mathrm{NH}_{4} \mathrm{Cl}$ solution and extracted by $\mathrm{CH}_{2} \mathrm{Cl}_{2}$ three times. The combined organic layer was washed with brine, dried over $\mathrm{Na}_{2} \mathrm{SO}_{4}$, and concentrated under reduced pressure. The residue was purified by silica gel flash column chromatography (hexane/EtOAc $=10 / 1$ ) to afford a light-yellow solid. The product was further purified by recrystallization from hexane to afford $\mathbf{1 f}$ as a yellow oil (628.2 $\mathrm{mg}, 1.24 \mathrm{mmol}, 40 \%$ yield).

${ }^{1} \mathbf{H}$ NMR (600 MHz, CDCl 3$) \delta 7.71(\mathrm{~d}, J=8.3 \mathrm{~Hz}, 2 \mathrm{H}), 7.64(\mathrm{dt}, J=8.1,1.4 \mathrm{~Hz}, 4 \mathrm{H}), 7.46-7.43$ $(\mathrm{m}, 2 \mathrm{H}), 7.41-7.38(\mathrm{~m}, 4 \mathrm{H}), 7.19(\mathrm{~d}, J=8.0 \mathrm{~Hz}, 2 \mathrm{H}), 4.46(\mathrm{~d}, J=8.7 \mathrm{~Hz}, 1 \mathrm{H}), 4.12$ (ddt, $J=8.8$, $6.9,2.0 \mathrm{~Hz}, 1 \mathrm{H}), 3.53(\mathrm{t}, J=7.0 \mathrm{~Hz}, 2 \mathrm{H}), 2.33(\mathrm{~s}, 3 \mathrm{H}), 2.16(\mathrm{td}, J=7.0,2.0,2 \mathrm{H}), 1.35(\mathrm{~d}, J=6.9$ $\mathrm{Hz}, 3 \mathrm{H}), 1.03$ (s, 9H). ${ }^{13} \mathbf{C}$ NMR (101 MHz, CDCl3) $\delta 143.3,137.3,135.5,133.4,129.7,129.3$, 127.7, 127.4 81.2, 80.1, 62.0, 41.6, 26.7, 23.7, 22.5, 21.4, 19.2. HRMS (ESI) $m / z:[\mathrm{M}+\mathrm{Na}]^{+}$calcd for $\mathrm{C}_{29} \mathrm{H}_{35} \mathrm{NO}_{3} \mathrm{SSiNa} 528.2004$; Found $m / z$ 528.1998.

(R)-N-(7-(1,3-dioxoisoindolin-2-yl)hept-3-yn-2-yl)-4-Methylbenzenesulfonamide (1g) 
<smiles>CC(C)O[Na]</smiles>

To a solution of 1 e $(600 \mathrm{mg}, 2 \mathrm{mmol})$ in DMF (10 mL), $\mathrm{K}_{2} \mathrm{CO}_{3}(1.11 \mathrm{~g}, 8 \mathrm{mmol}), \mathrm{KI}$ (33.2 mg, $0.2 \mathrm{mmol})$ and phthalimide $(588.5 \mathrm{mg}, 4 \mathrm{mmol})$ were added. The resulting mixture was heated to $60{ }^{\circ} \mathrm{C}$ using a oil bath for $12 \mathrm{~h}$. After completion, the reaction was quenched by adding water at room temperature. The mixture was extracted with ethyl acetate three times and dried over $\mathrm{Na}_{2} \mathrm{SO}_{4}$. The solvent was removed under reduced pressure, and the resulting oil was purified by column chromatography (hexane/EtOAc $=2 / 1)$ to afford $1 \mathrm{~g}(546.7 \mathrm{mg}, 67 \%)$ as a white solid.

${ }^{1}$ H NMR (600 MHz, CDCl3) $\delta 7.97-7.78$ (m, 2H), 7.82 - 7.64 (m, 4H), $7.44-7.22$ (m, 2H), $4.77(\mathrm{~d}, J=8.8 \mathrm{~Hz}, 1 \mathrm{H}), 4.08-3.98(\mathrm{~m}, 1 \mathrm{H}), 3.72-3.41(\mathrm{~m}, 2 \mathrm{H}), 2.39(\mathrm{~s}, 3 \mathrm{H}), 2.03-1.83(\mathrm{~m}$, 2H), $1.77-1.58(\mathrm{~m}, 2 \mathrm{H}), 1.31(\mathrm{~d}, J=6.9 \mathrm{~Hz}, 3 \mathrm{H}) .{ }^{\mathbf{1 3}} \mathbf{C} \mathbf{N M R}\left(\mathbf{1 5 1} \mathbf{M H z}, \mathbf{C D C l}_{3}\right) \delta 168.3,143.2$, 137.4, 134.1, 132.0, 129.4, 127.4, 123.2, 82.7, 80.2, 41.6, 36.8, 26.7, 23.8, 21.4, 16.0. HRMS (ESI) $m / z:[\mathrm{M}+\mathrm{Na}]^{+}$calcd for $\mathrm{C}_{22} \mathrm{H}_{22} \mathrm{~N}_{2} \mathrm{O}_{4} \mathrm{SNa}$ ) 433.1198; Found $m / z 433.1192$.

(R)-4-Methyl- $N$-(8-methylnon-5-yn-4-yl)benzenesulfonamide (1h)<smiles>CCCC(C#CCC(C)C)NC(C)C</smiles>

Compound $\mathbf{1 h}$ was synthesized according to General Procedure A.<smiles>CCCC=N[S+]([O-])Br</smiles>

S1h

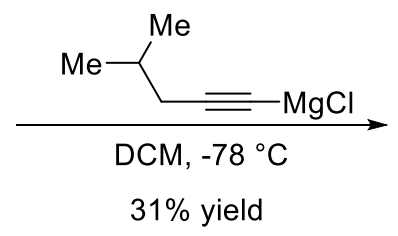<smiles>CCCC([NH3+])C#CCC(C)C</smiles><smiles>CCCC(C#CCC(C)C)N[S+]([O-])Br</smiles><smiles>CCCC(C#CCC(C)C)NS(C)(=O)=O</smiles>

$\underset{\mathrm{MeOH}, 0^{\circ} \mathrm{C} \text { to r.t. }}{\stackrel{4 \mathrm{M} \mathrm{HCl} \text { in dioxane }}{\longrightarrow}}$

$1 \mathrm{~h}$ 
To a solution of 4-methyl-1-pentyne (1.29 mL, $11 \mathrm{mmol}, 2.2$ equiv.) in THF $(1.5 \mathrm{~mL})$ at $0{ }^{\circ} \mathrm{C}, 2 \mathrm{M}$ $i P r \mathrm{MgCl}$ in THF (5 mL, $10 \mathrm{mmol}, 2.0$ equiv.) was added slowly. The resulting solution was allowed to warm to room temperature and stirred for $60 \mathrm{~min}$ to afford the 4-methyl-1-pentynyl magnesium chloride solution.

The freshly prepared 4-methyl-1-pentynyl magnesium chloride solution was slowly added into a solution of $N$-sulfinyl imine $\mathbf{S 1 h}\left(876.0 \mathrm{mg}, 5 \mathrm{mmol}, 1.0\right.$ equiv.) in $\mathrm{CH}_{2} \mathrm{Cl}_{2}(20 \mathrm{~mL})$ via cannula at $-78{ }^{\circ} \mathrm{C}$ under argon protection. The resulting solution was stirred at $-78{ }^{\circ} \mathrm{C}$ for $2 \mathrm{~h}$, then gradually warmed to room temperature and stirred overnight. The reaction was quenched by saturated $\mathrm{NH}_{4} \mathrm{Cl}$ solution, followed by extraction with EtOAc three times. The combined organic layer was washed with brine, dried over $\mathrm{Na}_{2} \mathrm{SO}_{4}$, and the combined organic layer was concentrated under reduced pressure. The residue was purified by silica gel flash column chromatography (hexane/EtOAc = 4/1) to afford S2h (401.1 mg, $1.56 \mathrm{mmol}, 31 \%$ yield) as a colorless oil.

$4 \mathrm{M} \mathrm{HCl}$ solution in dioxane $(6.4 \mathrm{mmol}, 1.6 \mathrm{~mL}, 4.0$ equiv.) was added into a solution of $\mathbf{S 2 h}$ (401.1 mg, $1.56 \mathrm{mmol})$ in $\mathrm{MeOH}(8 \mathrm{~mL})$. The reaction mixture was stirred at room temperature for $30 \mathrm{~min}$. The solvent was removed under reduced pressure to afford crude product $\mathbf{S 3 h}$, which was directly used in the next step without further purification. Crude product $\mathbf{S 3 h}$ was dissolved in $7 \mathrm{~mL} \mathrm{CH}_{2} \mathrm{Cl}_{2}$ at $0{ }^{\circ} \mathrm{C}$, followed by the addition of $\mathrm{Et}_{3} \mathrm{~N}$ (1.09 mL, $7.8 \mathrm{mmol}, 5$ equiv.) and $\mathrm{TsCl}$ (297.4 mg, $1.56 \mathrm{mmol}, 1.0$ equiv.). The resulting mixture was allowed to warm to room temperature and stirred overnight. The reaction was quenched with saturated $\mathrm{NH}_{4} \mathrm{Cl}$ solution and extracted by $\mathrm{CH}_{2} \mathrm{Cl}_{2}$ three times. The combined organic layer was washed with brine, dried over $\mathrm{Na}_{2} \mathrm{SO}_{4}$, and concentrated under reduced pressure. The residue was purified by silica gel flash column chromatography (hexane/EtOAc $=10 / 1)$ to afford a light-yellow solid. The product was further purified by recrystallization from hexane to afford $\mathbf{1 h}(200.8 \mathrm{mg}, 0.65 \mathrm{mmol}, 42 \%$ yield $)$ as a white needle.

${ }^{1} \mathbf{H}$ NMR (600 MHz, CDCl $) \delta 7.77(\mathrm{~d}, J=8.0 \mathrm{~Hz}, 2 \mathrm{H}), 7.28(\mathrm{~d}, J=7.9 \mathrm{~Hz}, 2 \mathrm{H}), 4.47$ (d, $J=9.1$ Hz, 1H), $4.09-3.99(\mathrm{~m}, 1 \mathrm{H}), 2.41(\mathrm{~s}, 3 \mathrm{H}), 1.78(\mathrm{dd}, J=6.5,2.1 \mathrm{~Hz}, 2 \mathrm{H}), 1.68-1.49$ (m, 3H), $1.44(\mathrm{~h}, J=7.4 \mathrm{~Hz}, 2 \mathrm{H}), 0.90(\mathrm{t}, J=7.3 \mathrm{~Hz}, 3 \mathrm{H}), 0.79$ (d, $J=6.7 \mathrm{~Hz}, 6 \mathrm{H}) .{ }^{13} \mathbf{C}$ NMR (101 MHz, CDCl3) $\delta 143.2,137.5,129.4,127.4,83.8,79.0,45.8,39.2,27.7,27.5,21.8,21.5,18.7,13.4$. HRMS (ESI) $m / z:[\mathrm{M}+\mathrm{Na}]^{+}$calcd for $\mathrm{C}_{17} \mathrm{H}_{25} \mathrm{NO}_{2} \mathrm{SNa} 330.1504$; Found $m / z$ 330.1506.

(R)-N-(2,7-dimethyloct-4-yn-3-yl)-4-Methylbenzenesulfonamide (1i) 


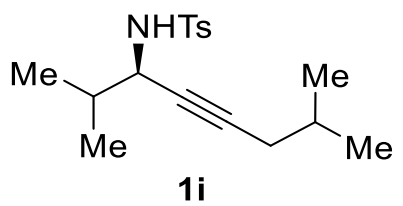

Compound 1i was synthesized according to General Procedure A.

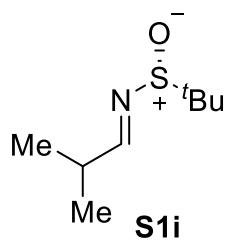

S1i

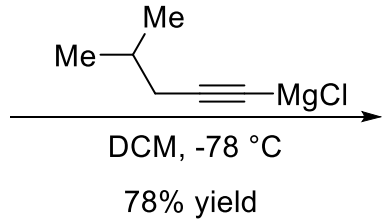

$78 \%$ yield

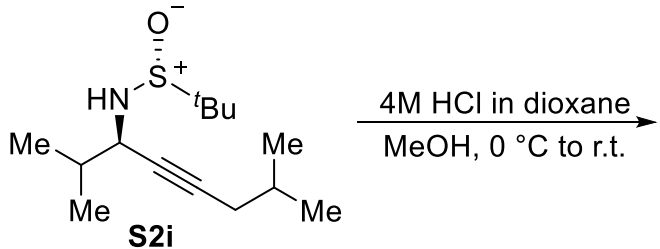

S2i<smiles>CC(C)CC#C[C@@H]([NH3+])C(C)C</smiles>

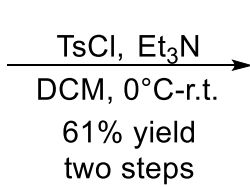<smiles>CC(C)CC#C[C@@H](N)C(C)C</smiles>

$1 \mathrm{i}$

To a solution of 4-methyl-1-pentyne (1.29 mL, $11 \mathrm{mmol}, 2.2$ equiv.) in THF $(1.5 \mathrm{~mL})$ at $0{ }^{\circ} \mathrm{C}, 2 \mathrm{M}$ $i P r \mathrm{MgCl}$ in THF (5 mL, $10 \mathrm{mmol}, 2.0$ equiv.) was added slowly. The resulting solution was allowed to warm to room temperature and stirred for $60 \mathrm{~min}$ to afford the 4-methyl-1-pentynyl magnesium chloride solution.

The freshly prepared 4-methyl-1-pentynyl magnesium chloride solution was slowly added into a solution of $N$-sulfinyl imine $\mathbf{S 1 i}\left(876.0 \mathrm{mg}, 5 \mathrm{mmol}, 1.0\right.$ equiv.) in $\mathrm{CH}_{2} \mathrm{Cl}_{2}(20 \mathrm{~mL})$ via cannula at $-78^{\circ} \mathrm{C}$ under argon protection. The resulting solution was stirred at $-78{ }^{\circ} \mathrm{C}$ for $2 \mathrm{~h}$, then gradually warmed to room temperature and stirred overnight. The reaction was quenched by saturated $\mathrm{NH}_{4} \mathrm{Cl}$ solution, followed by extraction with EtOAc three times. The combined organic layer was washed with brine, dried over $\mathrm{Na}_{2} \mathrm{SO}_{4}$, and the combined organic layer was concentrated under reduced pressure. The residue was purified by silica gel flash column chromatography (hexane/EtOAc $=$ 3/1) to afford S2i (1.0013 g, $3.89 \mathrm{mmol}, 78 \%$ yield) as a colorless oil.

4M HCl solution in dioxane (15.6 mmol, $3.9 \mathrm{~mL}, 4.0$ equiv.) was added into a solution of $\mathbf{S 2 i}$ $(1.0013 \mathrm{~g}, 3.89 \mathrm{mmol})$ in $\mathrm{MeOH}(19 \mathrm{~mL})$. The reaction mixture was stirred at room temperature for $30 \mathrm{~min}$. The solvent was removed under reduced pressure to afford crude product $\mathbf{S 3 i}$, which was directly used in the next step without further purification. Crude product S3i was dissolved in $20 \mathrm{~mL} \mathrm{CH}_{2} \mathrm{Cl}_{2}$ at $0{ }^{\circ} \mathrm{C}$, followed by the addition of $\mathrm{Et}_{3} \mathrm{~N}(2.73 \mathrm{~mL}, 19.5 \mathrm{mmol}, 5$ equiv. $)$ and $\mathrm{TsCl}$ 
(741.6 mg, $3.89 \mathrm{mmol}, 1.0$ equiv.). The resulting mixture was allowed to warm to room temperature and stirred overnight. The reaction was quenched with saturated $\mathrm{NH}_{4} \mathrm{Cl}$ solution and extracted by $\mathrm{CH}_{2} \mathrm{Cl}_{2}$ three times. The combined organic layer was washed with brine, dried over $\mathrm{Na}_{2} \mathrm{SO}_{4}$, and concentrated under reduced pressure. The residue was purified by silica gel flash column chromatography (hexane/EtOAc $=10 / 1)$ to afford a light-yellow solid. The product was further purified by recrystallization from hexane to afford $\mathbf{1 i}(724.7 \mathrm{mg}, 2.36 \mathrm{mmol}, 61 \%$ yield) as a white needle.

${ }^{1} \mathbf{H}$ NMR (500 MHz, CDCl 3$) \delta 7.77(\mathrm{~d}, J=8.1 \mathrm{~Hz}, 2 \mathrm{H}), 7.28(\mathrm{~d}, J=7.9 \mathrm{~Hz}, 2 \mathrm{H}), 4.52(\mathrm{~d}, J=9.4$ $\mathrm{Hz}, 1 \mathrm{H}), 3.95-3.81(\mathrm{~m}, 1 \mathrm{H}), 2.41(\mathrm{~s}, 3 \mathrm{H}), 1.91-1.83(\mathrm{~m}, 1 \mathrm{H}), 1.78(\mathrm{dd}, J=6.4,2.2 \mathrm{~Hz}, 2 \mathrm{H})$, 1.54 (non, $J=6.6 \mathrm{~Hz}, 1 \mathrm{H}), 0.95(\mathrm{~d}, J=6.7 \mathrm{~Hz}, 6 \mathrm{H}), 0.80(\mathrm{~d}, J=6.7 \mathrm{~Hz}, 6 \mathrm{H}) .{ }^{13} \mathrm{C} \mathrm{NMR}(\mathbf{1 0 1} \mathbf{M H z}$, $\left.\mathbf{C D C l}_{3}\right) \delta 143.2,137.5,129.4,127.4,84.6,77.4,51.9,33.9,27.7,27.5,21.8,21.5,18.7,17.5$. HRMS (ESI) $m / z:[\mathrm{M}+\mathrm{Na}]^{+}$calcd for $\mathrm{C}_{17} \mathrm{H}_{25} \mathrm{NO}_{2} \mathrm{SNa} 330.1504$; Found $m / z 330.1508$.

\section{(R)-N-(1-cyclopropyl-5-methylhex-2-yn-1-yl)-4-Methylbenzenesulfonamide (1j)}

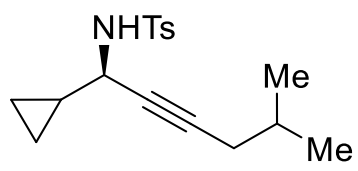

$1 \mathrm{j}$

Compound $\mathbf{1 j}$ was synthesized according to General Procedure A.

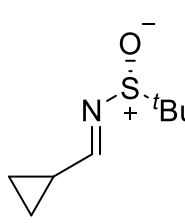

s1j
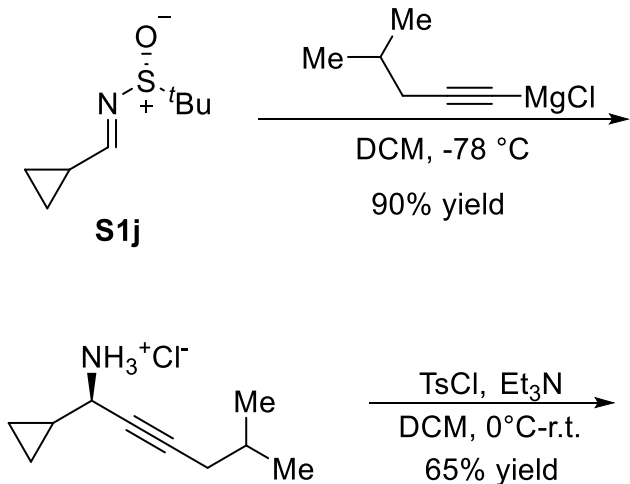

S3j

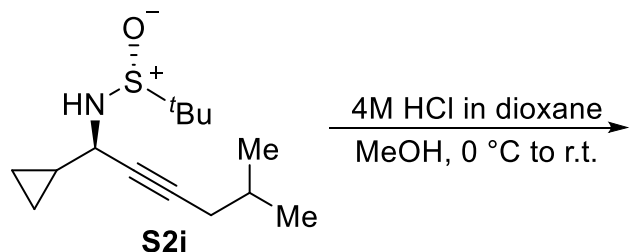

S2j

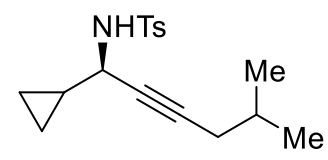

1j

To a solution of 4-methyl-1-pentyne (1.29 mL, $11 \mathrm{mmol}, 2.2$ equiv.) in THF $(1.5 \mathrm{~mL})$ at $0{ }^{\circ} \mathrm{C}, 2 \mathrm{M}$ iPr $\mathrm{MgCl}$ in THF ( $5 \mathrm{~mL}, 10 \mathrm{mmol}, 2.0$ equiv.) was added slowly. The resulting solution was 
allowed to warm to room temperature and stirred for $60 \mathrm{~min}$ to afford the 4-methyl-1-pentynyl magnesium chloride solution.

The freshly prepared 4-methyl-1-pentynyl magnesium chloride solution was slowly added into a solution of $N$-sulfinyl imine $\mathbf{S 1 j}$ (866.3 mg, $5 \mathrm{mmol}, 1.0$ equiv.) in $\mathrm{CH}_{2} \mathrm{Cl}_{2}(20 \mathrm{~mL}$ ) via cannula at $-78{ }^{\circ} \mathrm{C}$ under argon protection. The resulting solution was stirred at $-78{ }^{\circ} \mathrm{C}$ for $2 \mathrm{~h}$, then gradually warmed to room temperature and stirred overnight. The reaction was quenched by saturated $\mathrm{NH}_{4} \mathrm{Cl}$ solution, followed by extraction with EtOAc three times. The combined organic layer was washed with brine, dried over $\mathrm{Na}_{2} \mathrm{SO}_{4}$, and the combined organic layer was concentrated under reduced pressure. The residue was purified by silica gel flash column chromatography (hexane/EtOAc = 3/1) to afford $\mathbf{S 2 \mathbf { j }}$ (1.1424 g, $4.47 \mathrm{mmol}, 90 \%$ yield) as a colorless oil.

4M HCl solution in dioxane (18.0 mmol, $4.5 \mathrm{~mL}, 4.0$ equiv.) was added into a solution of $\mathbf{S} 2 \mathbf{j}$ $(1.1424 \mathrm{~g}, 4.47 \mathrm{mmol})$ in $\mathrm{MeOH}(22 \mathrm{~mL})$. The reaction mixture was stirred at room temperature for $30 \mathrm{~min}$. The solvent was removed under reduced pressure to afford crude product $\mathbf{S 3 \mathbf { j }}$, which was directly used in the next step without further purification. Crude product $\mathbf{S 3 \mathbf { j }}$ was dissolved in $20 \mathrm{~mL} \mathrm{CH}_{2} \mathrm{Cl}_{2}$ at $0{ }^{\circ} \mathrm{C}$, followed by the addition of $\mathrm{Et}_{3} \mathrm{~N}$ (3.1 mL, $22.3 \mathrm{mmol}, 5$ equiv.) and TsCl (852.2 $\mathrm{mg}, 4.47 \mathrm{mmol}, 1.0$ equiv.). The resulting mixture was allowed to warm to room temperature and stirred overnight. The reaction was quenched with saturated $\mathrm{NH}_{4} \mathrm{Cl}$ solution and extracted by $\mathrm{CH}_{2} \mathrm{Cl}_{2}$ three times. The combined organic layer was washed with brine, dried over $\mathrm{Na}_{2} \mathrm{SO}_{4}$, and concentrated under reduced pressure. The residue was purified by silica gel flash column chromatography (hexane/EtOAc $=10 / 1$ ) to afford a light-yellow solid. The product was further purified by recrystallization from hexane to afford $\mathbf{1 j}$ (882.9 $\mathrm{mg}, 2.89 \mathrm{mmol}, 65 \%$ yield) as a white needle.

${ }^{1}$ H NMR (500 MHz, CDCl 3$) \delta 7.77(\mathrm{~d}, J=8.3 \mathrm{~Hz}, 2 \mathrm{H}), 7.27(\mathrm{~d}, J=7.9 \mathrm{~Hz}, 2 \mathrm{H}), 4.71(\mathrm{~d}, J=8.8$ $\mathrm{Hz}, 1 \mathrm{H}), 4.20-4.13(\mathrm{~m}, 1 \mathrm{H}), 2.41(\mathrm{~s}, 3 \mathrm{H}), 1.76(\mathrm{dt}, J=6.3,2.0 \mathrm{~Hz}, 2 \mathrm{H}), 1.54$ (non, $J=6.6 \mathrm{~Hz}$, 1H), $1.17-1.07(\mathrm{~m}, 1 \mathrm{H}), 0.79(\mathrm{~d}, J=6.6 \mathrm{~Hz}, 6 \mathrm{H}) 0.50-0.35(\mathrm{~m}, 4 \mathrm{H}) .{ }^{13} \mathrm{C}$ NMR (101 MHz, $\left.\mathbf{C D C l}_{3}\right) \delta 143.1,137.7,129.4,127.3,84.4,76.0,49.0,27.6,27.5,21.8,21.5,15.7,2.9,1.4$. HRMS (ESI) $m / z:[\mathrm{M}+\mathrm{Na}]^{+}$calcd for $\mathrm{C}_{17} \mathrm{H}_{23} \mathrm{NO}_{2} \mathrm{SNa} 328.1347$; Found $\mathrm{m} / z$ 328.1352.

\section{(R)-4-Methyl-N-(2,2,7-trimethyloct-4-yn-3-yl)benzenesulfonamide (1k)}




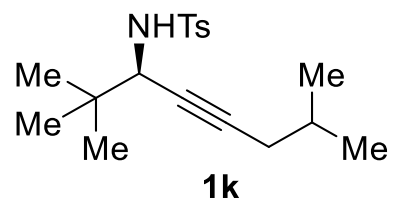

Compound 1k was synthesized according to General Procedure A.
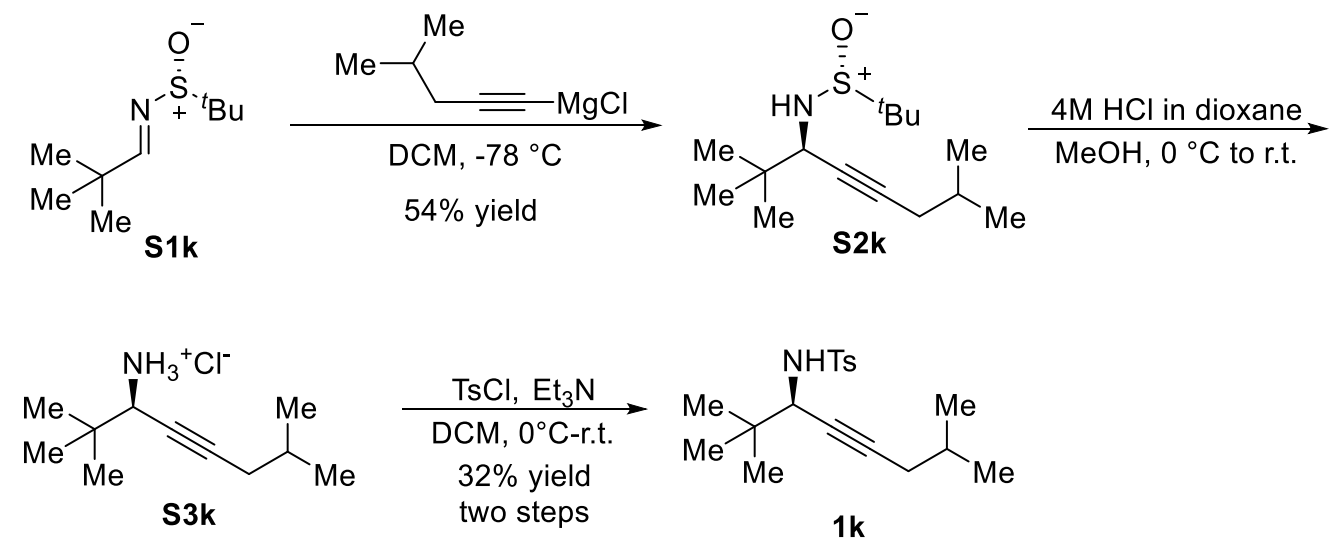

To a solution of 4-methyl-1-pentyne (1.94 mL, $16.5 \mathrm{mmol}, 3.3$ equiv.) in THF (2.5 mL) at $0{ }^{\circ} \mathrm{C}$, $2 \mathrm{M} i \operatorname{Pr} \mathrm{MgCl}$ in THF (7.5 mL, $15 \mathrm{mmol}, 3.0$ equiv.) was added slowly. The resulting solution was allowed to warm to room temperature and stirred for $60 \mathrm{~min}$ to afford the 4-methyl-1-pentynyl magnesium chloride solution.

The freshly prepared 4-methyl-1-pentynyl magnesium chloride solution was slowly added into a solution of $N$-sulfinyl imine S1k (946.5 mg, $5 \mathrm{mmol}, 1.0$ equiv.) in $\mathrm{CH}_{2} \mathrm{Cl}_{2}(20 \mathrm{~mL})$ via cannula at $-78{ }^{\circ} \mathrm{C}$ under argon protection. The resulting solution was stirred at $-78{ }^{\circ} \mathrm{C}$ for $2 \mathrm{~h}$, then gradually warmed to room temperature and stirred overnight. The reaction was quenched by saturated $\mathrm{NH}_{4} \mathrm{Cl}$ solution, followed by extraction with EtOAc three times. The combined organic layer was washed with brine, dried over $\mathrm{Na}_{2} \mathrm{SO}_{4}$, and the combined organic layer was concentrated under reduced pressure. The residue was purified by silica gel flash column chromatography (hexane/EtOAc $=$ 3/1) to afford S2k (725.7 $\mathrm{mg}, 2.68 \mathrm{mmol}, 54 \%$ yield) as a colorless oil.

4M HCl solution in dioxane (11.2 mmol, $2.8 \mathrm{~mL}, 4.0$ equiv.) was added into a solution of S2k (725.7 $\mathrm{mg}, 2.68 \mathrm{mmol})$ in $\mathrm{MeOH}(15 \mathrm{~mL})$. The reaction mixture was stirred at room temperature for $30 \mathrm{~min}$. The solvent was removed under reduced pressure to afford crude product $\mathbf{S 3 k}$, which was directly used in the next step without further purification. Crude product S3k was dissolved in $14 \mathrm{~mL} \mathrm{CH}_{2} \mathrm{Cl}_{2}$ at $0{ }^{\circ} \mathrm{C}$, followed by the addition of $\mathrm{Et}_{3} \mathrm{~N}$ (1.97 mL, $13.4 \mathrm{mmol}, 5$ equiv.) and 
$\mathrm{TsCl}$ (613.1 mg, $3.89 \mathrm{mmol}, 1.2$ equiv.). The resulting mixture was allowed to warm to room temperature and stirred overnight. The reaction was quenched with saturated $\mathrm{NH}_{4} \mathrm{Cl}$ solution and extracted by $\mathrm{CH}_{2} \mathrm{Cl}_{2}$ three times. The combined organic layer was washed with brine, dried over $\mathrm{Na}_{2} \mathrm{SO}_{4}$, and concentrated under reduced pressure. The residue was purified by silica gel flash column chromatography (hexane/EtOAc $=10 / 1$ ) to afford a light-yellow solid. The product was further purified by recrystallization from hexane to afford $\mathbf{1 k}(272.0 \mathrm{mg}, 0.85 \mathrm{mmol}, 32 \%$ yield $)$ as a white needle.

${ }^{1}$ H NMR (600 MHz, CDCl $) \delta 7.76(\mathrm{~d}, J=8.3 \mathrm{~Hz}, 2 \mathrm{H}), 7.28(\mathrm{~d}, J=8.0 \mathrm{~Hz}, 2 \mathrm{H}), 4.38(\mathrm{~d}, J=10.2$ $\mathrm{Hz}, 1 \mathrm{H}), 3.70(\mathrm{dt}, J=10.3,2.1 \mathrm{~Hz}, 1 \mathrm{H}), 2.41$ (s, 3H), 1.74 (dd, $J=6.5,2.1 \mathrm{~Hz}, 2 \mathrm{H}), 1.52$ (non, $J$ $=6.7 \mathrm{~Hz}, 1 \mathrm{H}), 0.97(\mathrm{~s}, 9 \mathrm{H}), 0.78(\mathrm{~d}, J=6.7 \mathrm{~Hz}, 6 \mathrm{H}) .{ }^{13} \mathbf{C}$ NMR (101 MHz, CDCl $) \delta 143.1,137.4$, 129.4, 127.5, 84.5, 77.8, 55.8, 35.6, 27.7, 27.5, 25.9, 21.82, 21.80, 21.5. HRMS (ESI) $\mathrm{m} / z$ : $[\mathrm{M}+\mathrm{Na}]^{+}$calcd for $\mathrm{C}_{18} \mathrm{H}_{27} \mathrm{NO}_{2} \mathrm{SNa} 344.1660$; Found $\mathrm{m} / z$ 344.1652.

(R)-4-Methyl- $N$-(5-methyl-1-phenylhex-2-yn-1-yl)benzenesulfonamide (11)

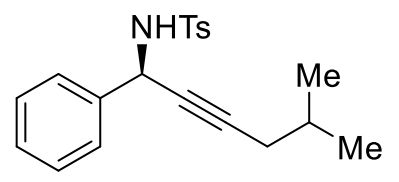

1 I

Compound 11 was synthesized according to General Procedure A.

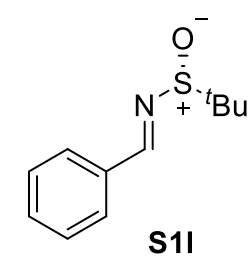

S1I

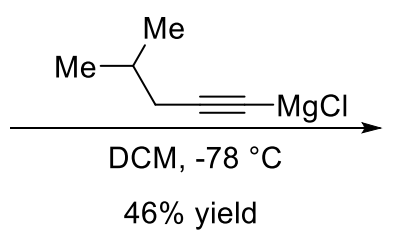

$46 \%$ yield

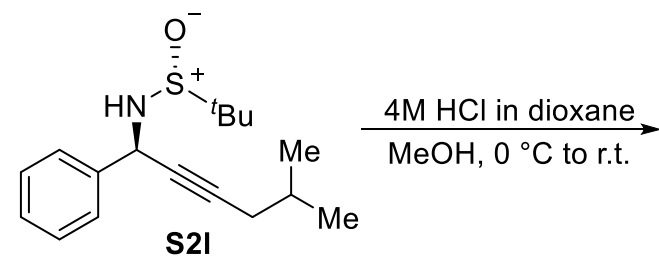

S2I

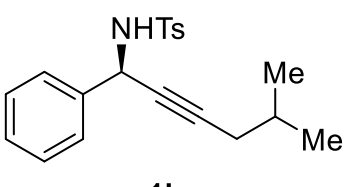

11

To a solution of 4-methyl-1-pentyne (1.94 mL, $16.5 \mathrm{mmol}, 3.3$ equiv.) in THF $(2.5 \mathrm{~mL})$ at $0{ }^{\circ} \mathrm{C}$, 2M $i P r \mathrm{MgCl}$ in THF (7.5 mL, $15 \mathrm{mmol}, 3.0$ equiv.) was added slowly. The resulting solution was 
allowed to warm to room temperature and stirred for $60 \mathrm{~min}$ to afford the 4-methyl-1-pentynyl magnesium chloride solution.

The freshly prepared 4-methyl-1-pentynyl magnesium chloride solution was slowly added into a solution of $N$-sulfinyl imine $\mathbf{S 1 l}$ (1.0465 g, $5 \mathrm{mmol}, 1.0$ equiv.) in $\mathrm{CH}_{2} \mathrm{Cl}_{2}$ (25 mL) via cannula at $-78{ }^{\circ} \mathrm{C}$ under argon protection. The resulting solution was stirred at $-78{ }^{\circ} \mathrm{C}$ for $2 \mathrm{~h}$, then gradually warmed to room temperature and stirred overnight. The reaction was quenched by saturated $\mathrm{NH}_{4} \mathrm{Cl}$ solution, followed by extraction with EtOAc three times. The combined organic layer was washed with brine, dried over $\mathrm{Na}_{2} \mathrm{SO}_{4}$, and the combined organic layer was concentrated under reduced pressure. The residue was purified by silica gel flash column chromatography (hexane/EtOAc = 3/1) to afford $\mathbf{S 2 l}$ (708.6 $\mathrm{mg}, 2.30 \mathrm{mmol}, 46 \%$ yield) as a colorless oil.

4M HCl solution in dioxane (9.2 mmol, $2.30 \mathrm{~mL}, 4.0$ equiv.) was added into a solution of $\mathbf{S 2 l}$ (708.6 mg, $2.30 \mathrm{mmol})$ in $\mathrm{MeOH}(12 \mathrm{~mL})$. The reaction mixture was stirred at room temperature for $30 \mathrm{~min}$. The solvent was removed under reduced pressure to afford crude product $\mathbf{S 3 I}$, which was directly used in the next step without further purification. Crude product S3I was dissolved in $12 \mathrm{~mL} \mathrm{CH}_{2} \mathrm{Cl}_{2}$ at $0{ }^{\circ} \mathrm{C}$, followed by the addition of $\mathrm{Et}_{3} \mathrm{~N}$ (1.62 mL, $11.5 \mathrm{mmol}, 5$ equiv.) and TsCl (526.2 $\mathrm{mg}, 2.76 \mathrm{mmol}, 1.2$ equiv.). The resulting mixture was allowed to warm to room temperature and stirred overnight. The reaction was quenched with saturated $\mathrm{NH}_{4} \mathrm{Cl}$ solution and extracted by $\mathrm{CH}_{2} \mathrm{Cl}_{2}$ three times. The combined organic layer was washed with brine, dried over $\mathrm{Na}_{2} \mathrm{SO}_{4}$, and concentrated under reduced pressure. The residue was purified by silica gel flash column chromatography (hexane/EtOAc $=10 / 1$ ) to afford a light-yellow solid. The product was further purified by recrystallization from hexane to afford $\mathbf{1 1}(615.9 \mathrm{mg}, 1.8 \mathrm{mmol}, 78 \%$ yield $)$ as a white needle.

${ }^{1} \mathbf{H}$ NMR (600 MHz, CDCl 3$) \delta 7.77(\mathrm{~d}, J=8.2 \mathrm{~Hz}, 2 \mathrm{H}), 7.47(\mathrm{~d}, J=7.2 \mathrm{~Hz}, 2 \mathrm{H}), 7.37-7.23(\mathrm{~m}$, $5 \mathrm{H}), 5.31(\mathrm{dt}, J=8.9,2.2 \mathrm{~Hz}, 1 \mathrm{H}), 4.83(\mathrm{~d}, J=8.8 \mathrm{~Hz}, 1 \mathrm{H}), 2.42(\mathrm{~s}, 3 \mathrm{H}), 1.87(\mathrm{dd}, J=6.6,2.1 \mathrm{~Hz}$, 2H), $1.67-1.54(\mathrm{~m}, 1 \mathrm{H}), 0.84(\mathrm{~d}, J=6.7 \mathrm{~Hz}, 6 \mathrm{H}) .{ }^{13} \mathbf{C}$ NMR (101 MHz, CDCl 3$) \delta 143.3,138.2$, $137.5,129.4,128.5,128.2,127.4,127.2,86.4,77.5,49.4,27.72,27.70,21.9,21.5$. HRMS (ESI) $m / z:[\mathrm{M}+\mathrm{Na}]^{+}$calcd for $\mathrm{C}_{20} \mathrm{H}_{23} \mathrm{NO}_{2} \mathrm{SNa} 364.1347$; Found $m / z$ 364.1353.

(R)-N-(1-(4-methoxyphenyl)-5-methylhex-2-yn-1-yl)-4-Methylbenzenesulfonamide (1m) 


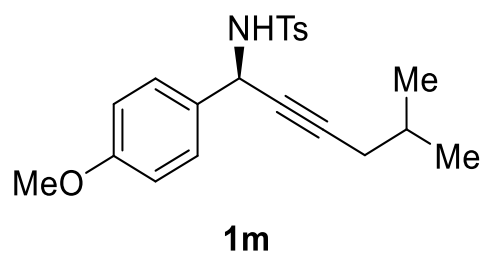

Compound 1m was synthesized according to General Procedure A.
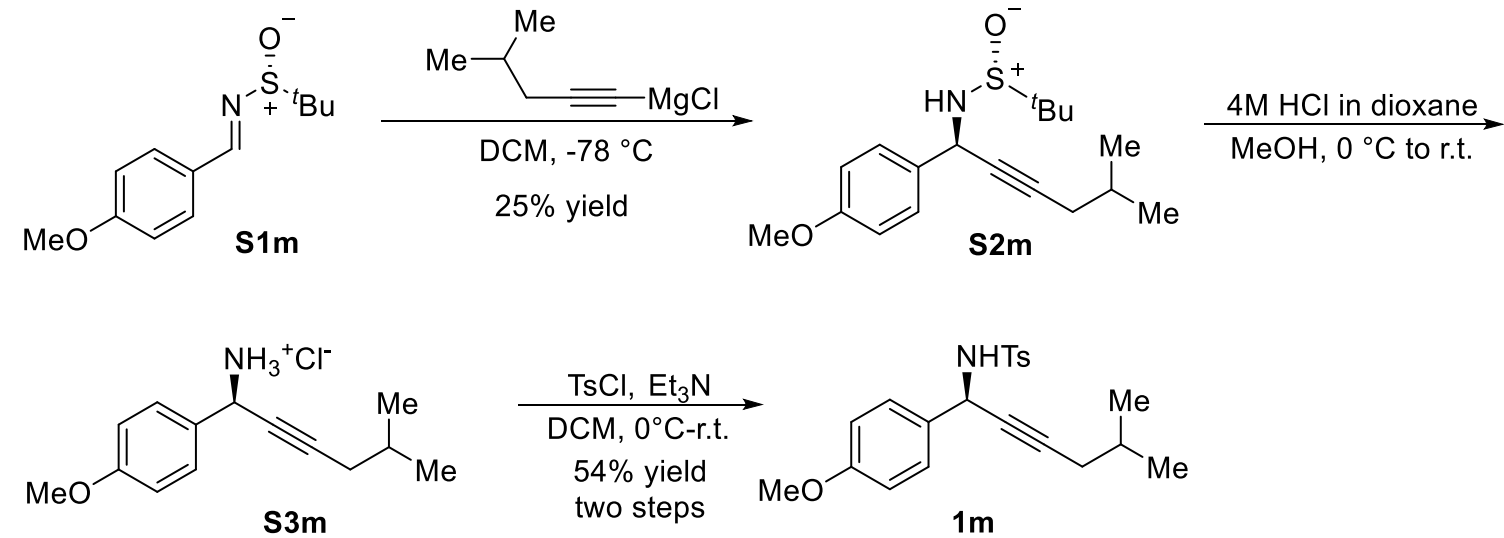

To a solution of 4-methyl-1-pentyne $(1.29 \mathrm{~mL}, 11 \mathrm{mmol}, 2.2$ equiv. $)$ in $\mathrm{THF}(1.5 \mathrm{~mL})$ at $0{ }^{\circ} \mathrm{C}, 2 \mathrm{M}$ $i P r \mathrm{MgCl}$ in THF (5.0 mL, $10 \mathrm{mmol}, 2.0$ equiv.) was added slowly. The resulting solution was allowed to warm to room temperature and stirred for $60 \mathrm{~min}$ to afford the 4-methyl-1-pentynyl magnesium chloride solution.

The freshly prepared 4-methyl-1-pentynyl magnesium chloride solution was slowly added into a solution of $N$-sulfinyl imine $\mathbf{S 1 m}$ (1.1965 mg, $5 \mathrm{mmol}$, 1.0 equiv.) in $\mathrm{CH}_{2} \mathrm{Cl}_{2}(20 \mathrm{~mL})$ via cannula at $-78{ }^{\circ} \mathrm{C}$ under argon protection. The resulting solution was stirred at $-78{ }^{\circ} \mathrm{C}$ for $2 \mathrm{~h}$, then gradually warmed to room temperature and stirred overnight. The reaction was quenched by saturated $\mathrm{NH}_{4} \mathrm{Cl}$ solution, followed by extraction with EtOAc three times. The combined organic layer was washed with brine, dried over $\mathrm{Na}_{2} \mathrm{SO}_{4}$, and the combined organic layer was concentrated under reduced pressure. The residue was purified by silica gel flash column chromatography (hexane/EtOAc $=$ 3/1) to afford $\mathbf{S 2 m}$ (405.4 $\mathrm{mg}, 1.26 \mathrm{mmol}, 25 \%$ yield) as a colorless oil.

4M HCl solution in dioxane (5.2 mmol, $1.3 \mathrm{~mL}, 4.0$ equiv.) was added into a solution of $\mathbf{S 2 m}$ (405.4 mg, $1.26 \mathrm{mmol})$ in $\mathrm{MeOH}(7 \mathrm{~mL})$. The reaction mixture was stirred at room temperature for $30 \mathrm{~min}$. The solvent was removed under reduced pressure to afford crude product $\mathbf{S 3 m}$, which was directly used in the next step without further purification. Crude product $\mathbf{S 3 m}$ was dissolved 
in $7 \mathrm{~mL} \mathrm{CH}_{2} \mathrm{Cl}_{2}$ at $0{ }^{\circ} \mathrm{C}$, followed by the addition of $\mathrm{Et}_{3} \mathrm{~N}(0.92 \mathrm{~mL}, 6.30 \mathrm{mmol}, 5$ equiv. $)$ and $\mathrm{TsCl}$ (240.2 $\mathrm{mg}, 1.26 \mathrm{mmol}, 1.2$ equiv.). The resulting mixture was allowed to warm to room temperature and stirred overnight. The reaction was quenched with saturated $\mathrm{NH}_{4} \mathrm{Cl}$ solution and extracted by $\mathrm{CH}_{2} \mathrm{Cl}_{2}$ three times. The combined organic layer was washed with brine, dried over $\mathrm{Na}_{2} \mathrm{SO}_{4}$, and concentrated under reduced pressure. The residue was purified by silica gel flash column chromatography (hexane/EtOAc $=10 / 1)$ to afford a light-yellow solid. The product was further purified by recrystallization from hexane to afford $\mathbf{1 m}(253.0 \mathrm{mg}, 0.68 \mathrm{mmol}, 54 \%$ yield $)$ as a white needle.

${ }^{1}$ H NMR (600 MHz, CDCl 3$) \delta 7.76(\mathrm{~d}, J=8.0 \mathrm{~Hz}, 2 \mathrm{H}), 7.38(\mathrm{~d}, J=8.4 \mathrm{~Hz}, 2 \mathrm{H}), 7.28(\mathrm{~d}, J=8.0$ $\mathrm{Hz}, 2 \mathrm{H}), 6.83(\mathrm{~d}, J=8.4 \mathrm{~Hz}, 2 \mathrm{H}), 5.30-5.23(\mathrm{~m}, 1 \mathrm{H}), 4.76(\mathrm{~d}, J=8.7 \mathrm{~Hz}, 1 \mathrm{H}), 3.79$ (s, 3H), 2.42 (s, 3H), $1.87(\mathrm{dd}, J=6.7,2.2 \mathrm{~Hz}, 2 \mathrm{H}), 1.65-1.55(\mathrm{~m}, 1 \mathrm{H}), 0.84$ (d, $J=6.7 \mathrm{~Hz}, 6 \mathrm{H}) .{ }^{13} \mathbf{C}$ NMR (151 MHz, CDCl3) $\delta$ 159.5, 143.2, 137.6, 130.3, 129.4, 128.5, 127.4, 113.8, 86.2, 76.8, 55.3, 49.0, 27.74, 27.72, 21.9, 21.5. HRMS (ESI) $m / z:[\mathrm{M}+\mathrm{Na}]^{+}$calcd for $\mathrm{C}_{21} \mathrm{H}_{25} \mathrm{NO}_{3} \mathrm{SNa}$ 394.1453; Found $m / z 394.1459$.

\section{(R)-4-Methyl-N-(5-methyl-1-(4-(trifluoromethyl)phenyl)hex-2-yn-1-yl)benzenesulfonamide}

(1n)

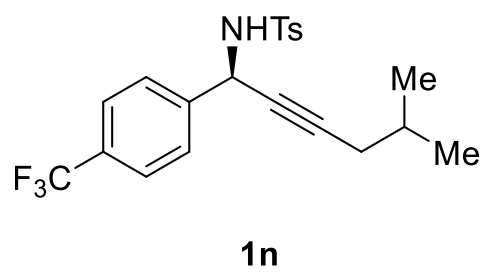

Compound 1n was synthesized according to General Procedure A.<smiles>[O-]S(=[Se])N=Cc1ccc(C(F)(F)F)cc1</smiles><smiles></smiles>
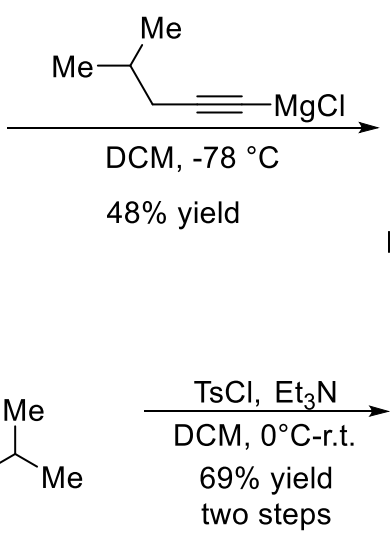

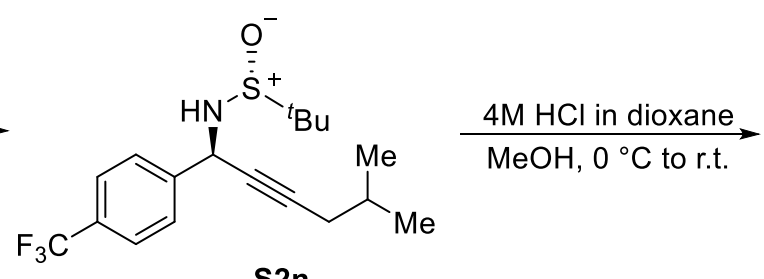

S2n<smiles>CC(C)CC#C[C@H](NC(C)C)c1ccc(C(F)(F)F)cc1</smiles> 
To a solution of 4-methyl-1-pentyne (1.94 mL, $16.5 \mathrm{mmol}, 3.3$ equiv.) in THF $(2.5 \mathrm{~mL})$ at $0{ }^{\circ} \mathrm{C}$, 2M iPr $\mathrm{MgCl}$ in THF (7.5 mL, $15 \mathrm{mmol}, 3.0$ equiv.) was added slowly. The resulting solution was allowed to warm to room temperature and stirred for $60 \mathrm{~min}$ to afford the 4-methyl-1-pentynyl magnesium chloride solution.

The freshly prepared 4-methyl-1-pentynyl magnesium chloride solution was slowly added into a solution of $N$-sulfinyl imine S1n (1.3865 mg, $5 \mathrm{mmol}, 1.0$ equiv.) in $\mathrm{CH}_{2} \mathrm{Cl}_{2}$ (25 mL) via cannula at $-78{ }^{\circ} \mathrm{C}$ under argon protection. The resulting solution was stirred at $-78{ }^{\circ} \mathrm{C}$ for $2 \mathrm{~h}$, then gradually warmed to room temperature and stirred overnight. The reaction was quenched by saturated $\mathrm{NH}_{4} \mathrm{Cl}$ solution, followed by extraction with EtOAc three times. The combined organic layer was washed with brine, dried over $\mathrm{Na}_{2} \mathrm{SO}_{4}$, and the combined organic layer was concentrated under reduced pressure. The residue was purified by silica gel flash column chromatography (hexane/EtOAc = 3/1) to afford S2n (861.5 mg, $2.40 \mathrm{mmol}, 48 \%$ yield) as a colorless oil.

4M HCl solution in dioxane (9.6 mmol, $2.4 \mathrm{~mL}, 4.0$ equiv.) was added into a solution of $\mathbf{S 2 n}$ $(861.5 \mathrm{mg}, 2.40 \mathrm{mmol})$ in $\mathrm{MeOH}(12 \mathrm{~mL})$. The reaction mixture was stirred at room temperature for $30 \mathrm{~min}$. The solvent was removed under reduced pressure to afford crude product $\mathbf{S 3 n}$, which was directly used in the next step without further purification. Crude product S3n was dissolved in $12 \mathrm{~mL} \mathrm{CH} \mathrm{Cl}_{2}$ at $0{ }^{\circ} \mathrm{C}$, followed by the addition of $\mathrm{Et}_{3} \mathrm{~N}$ (1.69 mL, $12.0 \mathrm{mmol}, 5$ equiv.) and $\mathrm{TsCl}$ (549.1 mg, $2.76 \mathrm{mmol}, 1.2$ equiv.). The resulting mixture was allowed to warm to room temperature and stirred overnight. The reaction was quenched with saturated $\mathrm{NH}_{4} \mathrm{Cl}$ solution and extracted by $\mathrm{CH}_{2} \mathrm{Cl}_{2}$ three times. The combined organic layer was washed with brine, dried over $\mathrm{Na}_{2} \mathrm{SO}_{4}$, and concentrated under reduced pressure. The residue was purified by silica gel flash column chromatography (hexane/EtOAc $=10 / 1$ ) to afford a light-yellow solid. The product was further purified by recrystallization from hexane to afford 1n $(677.7 \mathrm{mg}, 1.66 \mathrm{mmol}, 69 \%$ yield $)$ as a white needle.

${ }^{1}$ H NMR (600 MHz, CDCl 3$) \delta 7.72(\mathrm{~d}, J=8.2 \mathrm{~Hz}, 2 \mathrm{H}), 7.58(\mathrm{~d}, J=8.2 \mathrm{~Hz}, 2 \mathrm{H}), 7.54(\mathrm{~d}, J=8.3$ $\mathrm{Hz}, 2 \mathrm{H}), 7.26(\mathrm{~d}, J=8.2 \mathrm{~Hz}, 2 \mathrm{H}), 5.34(\mathrm{dt}, J=8.8,2.2 \mathrm{~Hz}, 1 \mathrm{H}), 5.00(\mathrm{~d}, J=8.7 \mathrm{~Hz}, 1 \mathrm{H}), 2.41$ (s, $3 \mathrm{H}), 1.90(\mathrm{dd}, J=6.5,2.2 \mathrm{~Hz}, 2 \mathrm{H}), 1.67-1.57(\mathrm{~m}, 1 \mathrm{H}), 0.84(\mathrm{~d}, J=6.7 \mathrm{~Hz}, 6 \mathrm{H}) .{ }^{13} \mathbf{C}$ NMR (101 MHz, CDCl3) $\delta 143.5,142.2(\mathrm{q}, J=1.5 \mathrm{~Hz}), 137.2,130.3(\mathrm{q}, J=32.4 \mathrm{~Hz}), 129.5,127.6,127.3$, $125.4(\mathrm{q}, J=3.8 \mathrm{~Hz}), 123.9(\mathrm{q}, J=272.1 \mathrm{~Hz}), 87.1,76.8,49.1,27.6,27.6,21.8,21.4 .{ }^{19} \mathbf{F}$ NMR 
(376 MHz, CDCl 3 ) $\delta$-63.49. HRMS (ESI) $m / z:[\mathrm{M}+\mathrm{Na}]^{+}$calcd for $\mathrm{C}_{21} \mathrm{H}_{22} \mathrm{~F}_{3} \mathrm{NO}_{2} \mathrm{SNa} 432.1221$;

Found $m / z 432.1227$.

(S)-N-(1-(furan-2-yl)-5-methylhex-2-yn-1-yl)-4-Methylbenzenesulfonamide (10)

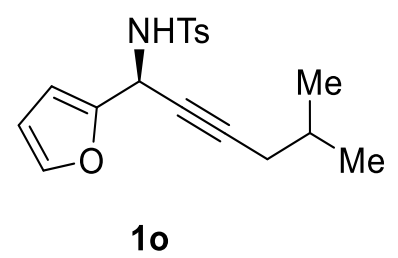

Compound 1o was synthesized according to General Procedure A.
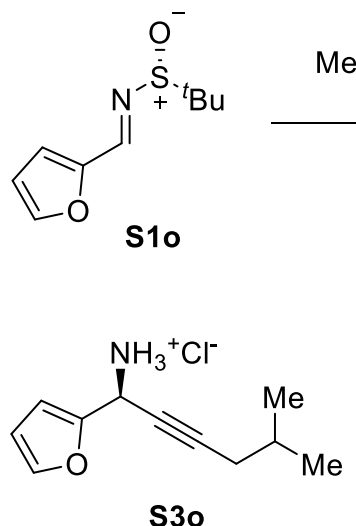
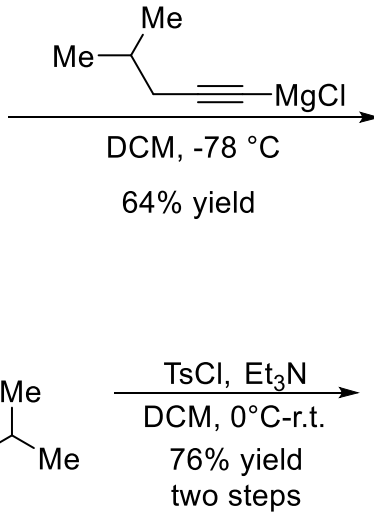
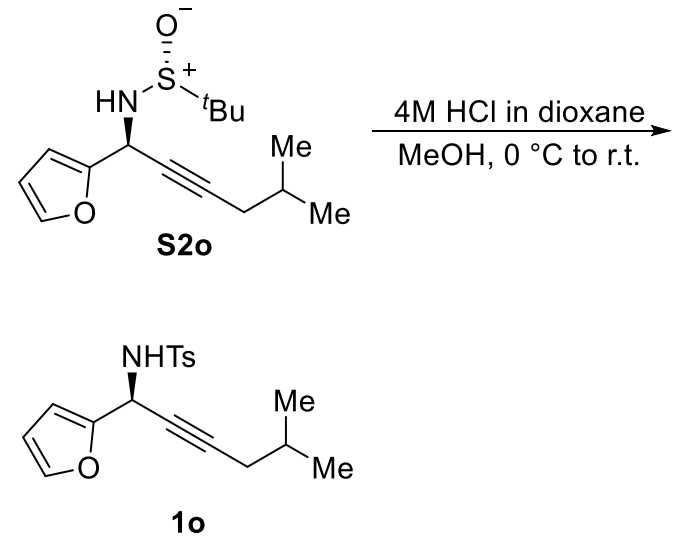

To a solution of 4-methyl-1-pentyne (1.94 mL, $16.5 \mathrm{mmol}, 3.3$ equiv.) in THF $(2.5 \mathrm{~mL})$ at $0{ }^{\circ} \mathrm{C}$, 2M iPr MgCl in THF (7.5 mL, 15 mmol, 3.0 equiv.) was added slowly. The resulting solution was allowed to warm to room temperature and stirred for 60 min to afford the 4-methyl-1-pentynyl magnesium chloride solution.

The freshly prepared 4-methyl-1-pentynyl magnesium chloride solution was slowly added into a solution of $N$-sulfinyl imine $\mathbf{S 1 o}\left(996.4 \mathrm{mg}, 5 \mathrm{mmol}, 1.0\right.$ equiv.) in $\mathrm{CH}_{2} \mathrm{Cl}_{2}(20 \mathrm{~mL}$ ) via cannula at $-78{ }^{\circ} \mathrm{C}$ under argon protection. The resulting solution was stirred at $-78{ }^{\circ} \mathrm{C}$ for $2 \mathrm{~h}$, then gradually warmed to room temperature and stirred overnight. The reaction was quenched by saturated $\mathrm{NH}_{4} \mathrm{Cl}$ solution, followed by extraction with EtOAc three times. The combined organic layer was washed with brine, dried over $\mathrm{Na}_{2} \mathrm{SO}_{4}$, and the combined organic layer was concentrated under reduced pressure. The residue was purified by silica gel flash column chromatography (hexane/EtOAc = 3/1) to afford S2o (895.2 $\mathrm{mg}, 3.18 \mathrm{mmol}, 64 \%$ yield) as a colorless oil. 
4M HCl solution in dioxane (12.8 mmol, $3.2 \mathrm{~mL}, 4.0$ equiv.) was added into a solution of $\mathbf{S 2 0}$ $(895.2 \mathrm{mg}, 3.18 \mathrm{mmol})$ in $\mathrm{MeOH}(15 \mathrm{~mL})$. The reaction mixture was stirred at room temperature for $30 \mathrm{~min}$. The solvent was removed under reduced pressure to afford crude product $\mathbf{S 3 o}$, which was directly used in the next step without further purification. Crude product $\mathbf{S 3 0}$ was dissolved in $16 \mathrm{~mL} \mathrm{CH}_{2} \mathrm{Cl}_{2}$ at $0{ }^{\circ} \mathrm{C}$, followed by the addition of $\mathrm{Et}_{3} \mathrm{~N}(2.23 \mathrm{~mL}, 15.9 \mathrm{mmol}, 5$ equiv.) and $\mathrm{TsCl}$ (727.0 mg, $3.81 \mathrm{mmol}, 1.2$ equiv.). The resulting mixture was allowed to warm to room temperature and stirred overnight. The reaction was quenched with saturated $\mathrm{NH}_{4} \mathrm{Cl}$ solution and extracted by $\mathrm{CH}_{2} \mathrm{Cl}_{2}$ three times. The combined organic layer was washed with brine, dried over $\mathrm{Na}_{2} \mathrm{SO}_{4}$, and concentrated under reduced pressure. The residue was purified by silica gel flash column chromatography (hexane/EtOAc $=5 / 1$ ) to afford a light-yellow solid. The product was further purified by recrystallization from hexane to afford 10 ( $803.6 \mathrm{mg}, 2.42 \mathrm{mmol}, 76 \%$ yield) as a white needle.

${ }^{1} \mathbf{H}$ NMR (600 MHz, CDCl 3$) \delta 7.75(\mathrm{~d}, J=8.2 \mathrm{~Hz}, 2 \mathrm{H}), 7.29(\mathrm{~d}, J=1.8 \mathrm{~Hz}, 1 \mathrm{H}), 7.27(\mathrm{~d}, J=8.3$ $\mathrm{Hz}, 2 \mathrm{H}), 6.29(\mathrm{~d}, J=3.2 \mathrm{~Hz}, 1 \mathrm{H}), 6.25(\mathrm{dd}, J=3.3,1.9 \mathrm{~Hz}, 1 \mathrm{H}), 5.35(\mathrm{dt}, J=8.7,2.2 \mathrm{~Hz}, 1 \mathrm{H})$, $4.89(\mathrm{~d}, J=8.7 \mathrm{~Hz}, 1 \mathrm{H}), 2.41$ (s, 3H), 1.89 (dd, $J=6.5,2.2 \mathrm{~Hz}, 2 \mathrm{H}), 1.63$ (non, $J=6.7 \mathrm{~Hz}, 1 \mathrm{H}$ ), $0.85(\mathrm{~d}, J=6.7 \mathrm{~Hz}, 6 \mathrm{H}) .{ }^{13} \mathbf{C}$ NMR (101 MHz, CDCl$) ~ \delta ~ 150.3,143.3,142.9,137.4,129.4,127.3$, 110.3, 108.0, 85.3, 75.5, 43.7, 27.7, 27.6, 21.9, 21.5. HRMS (ESI) $\mathrm{m} / \mathrm{z}:[\mathrm{M}+\mathrm{Na}]^{+}$calcd for $\mathrm{C}_{18} \mathrm{H}_{21} \mathrm{NO}_{3} \mathrm{SNa}$ 354.1140; Found $m / z$ 354.1151.

\section{(S)-4-Methyl- $N$-(5-methyl-1-(thiophen-2-yl)hex-2-yn-1-yl)benzenesulfonamide (1p)}

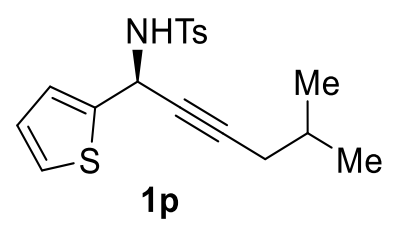

Compound 1p was synthesized according to General Procedure A. 

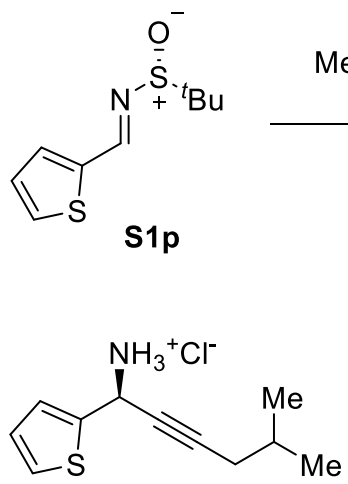

S3p
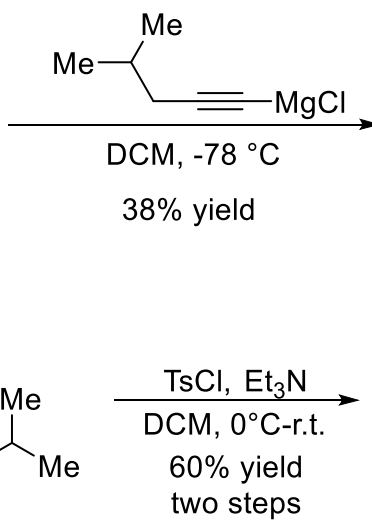
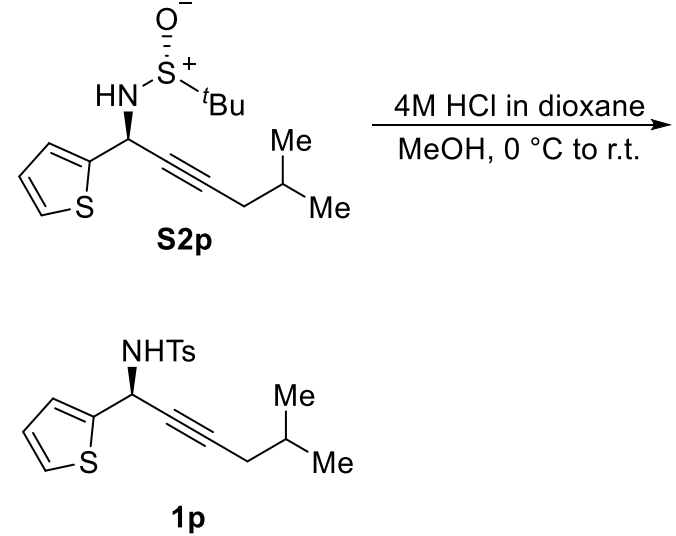

To a solution of 4-methyl-1-pentyne $(1.29 \mathrm{~mL}, 11 \mathrm{mmol}, 4.4$ equiv. $)$ in THF $(1.5 \mathrm{~mL})$ at $0{ }^{\circ} \mathrm{C}, 2 \mathrm{M}$ $i \operatorname{Pr} \mathrm{MgCl}$ in THF (5.0 mL, $10 \mathrm{mmol}, 4.0$ equiv.) was added slowly. The resulting solution was allowed to warm to room temperature and stirred for $60 \mathrm{~min}$ to afford the 4-methyl-1-pentynyl magnesium chloride solution.

The freshly prepared 4-methyl-1-pentynyl magnesium chloride solution was slowly added into a solution of $N$-sulfinyl imine $\mathbf{S 1 p}$ (538 mg, $2.5 \mathrm{mmol}, 1.0$ equiv.) in $\mathrm{CH}_{2} \mathrm{Cl}_{2}$ (25 mL) via cannula at $-78{ }^{\circ} \mathrm{C}$ under argon protection. The resulting solution was stirred at $-78{ }^{\circ} \mathrm{C}$ for $2 \mathrm{~h}$, then gradually warmed to room temperature and stirred overnight. The reaction was quenched by saturated $\mathrm{NH}_{4} \mathrm{Cl}$ solution, followed by extraction with EtOAc three times. The combined organic layer was washed with brine, dried over $\mathrm{Na}_{2} \mathrm{SO}_{4}$, and the combined organic layer was concentrated under reduced pressure. The residue was purified by silica gel flash column chromatography (hexane/EtOAc $=$ 3/1) to afford S2p (280.5 mg, $0.94 \mathrm{mmol}, 38 \%$ yield) as a colorless oil.

4M HCl solution in dioxane (3.76 mmol, $0.94 \mathrm{~mL}, 4.0$ equiv.) was added into a solution of $\mathbf{S 2 p}$ (280.5 mg, $0.94 \mathrm{mmol})$ in $\mathrm{MeOH}(5 \mathrm{~mL})$. The reaction mixture was stirred at room temperature for $30 \mathrm{~min}$. The solvent was removed under reduced pressure to afford crude product $\mathbf{S 3} \mathbf{p}$, which was directly used in the next step without further purification. Crude product S3p was dissolved in $5 \mathrm{~mL} \mathrm{CH}_{2} \mathrm{Cl}_{2}$ at $0{ }^{\circ} \mathrm{C}$, followed by the addition of $\mathrm{Et}_{3} \mathrm{~N}(0.70 \mathrm{~mL}, 4.70 \mathrm{mmol}, 5$ equiv. $)$ and $\mathrm{TsCl}$ (229.0 mg, $1.20 \mathrm{mmol}, 1.2$ equiv.). The resulting mixture was allowed to warm to room temperature and stirred overnight. The reaction was quenched with saturated $\mathrm{NH}_{4} \mathrm{Cl}$ solution and extracted by $\mathrm{CH}_{2} \mathrm{Cl}_{2}$ three times. The combined organic layer was washed with brine, dried over $\mathrm{Na}_{2} \mathrm{SO}_{4}$, and concentrated under reduced pressure. The residue was purified by silica gel flash column chromatography (hexane/EtOAc $=5 / 1$ ) to afford a light-yellow solid. The product was 
further purified by recrystallization from hexane to afford $1 \mathbf{p}(196.2 \mathrm{mg}, 0.56 \mathrm{mmol}, 60 \%$ yield) as a white needle.

${ }^{1}$ H NMR $\left(600 \mathrm{MHz}, \mathbf{C D C l}_{3}\right) \delta 7.71(\mathrm{~d}, J=8.3 \mathrm{~Hz}, 2 \mathrm{H}), 7.22(\mathrm{~d}, J=8.0 \mathrm{~Hz}, 2 \mathrm{H}), 7.15(\mathrm{dd}, J=$ $5.1,1.3 \mathrm{~Hz}, 1 \mathrm{H}), 7.01(\mathrm{dt}, J=3.6,1.2 \mathrm{~Hz}, 1 \mathrm{H}), 6.84(\mathrm{dd}, J=5.1,3.6 \mathrm{~Hz}, 1 \mathrm{H}), 5.44(\mathrm{dtd}, J=9.0$, $2.1,1.1 \mathrm{~Hz}, 1 \mathrm{H}), 4.83(\mathrm{~d}, J=9.0 \mathrm{~Hz}, 1 \mathrm{H}), 2.36(\mathrm{~s}, 3 \mathrm{H}), 1.81(\mathrm{dt}, J=6.4,2.0 \mathrm{~Hz}, 2 \mathrm{H}), 1.56$ (non, $J$ $=6.6 \mathrm{~Hz}, 1 \mathrm{H}), 0.79(\mathrm{~d}, J=6.7 \mathrm{~Hz}, 6 \mathrm{H}) .{ }^{13} \mathbf{C} \mathbf{N M R}\left(\mathbf{1 0 1} \mathbf{~ M H z}, \mathbf{C D C l}_{3}\right) \delta 143.4,142.5,137.4,129.5$, $127.4,126.8,126.1,126.0,85.7,77.4,45.4,27.7,27.6,21.9,21.5$. HRMS (ESI) $\mathrm{m} / z:[\mathrm{M}+\mathrm{Na}]^{+}$ calcd for $\mathrm{C}_{18} \mathrm{H}_{21} \mathrm{NO}_{2} \mathrm{~S}_{2} \mathrm{Na} 370.0912$; Found $m / z 370.0917$.

(S)-4-Methyl- $N$-(5-methyl-1-(1-tosyl-1H-indol-3-yl)hex-2-yn-1-yl)benzenesulfonamide (1q)

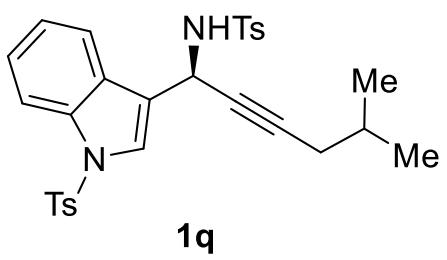

Compound 1q was synthesized according to General Procedure A.
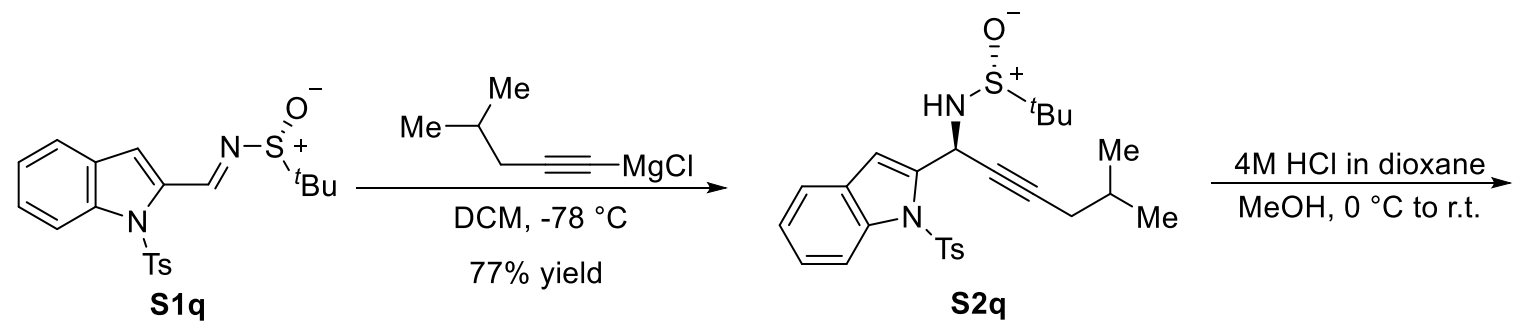

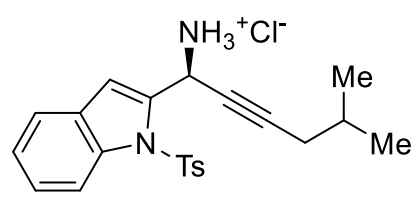

s3q

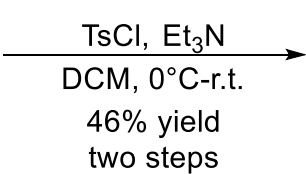

two steps

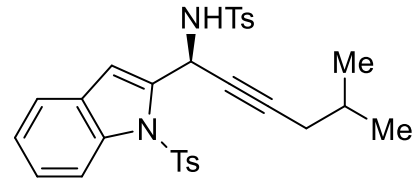

$1 q$

To a solution of 4-methyl-1-pentyne (1.94 mL, $16.5 \mathrm{mmol}, 3.3$ equiv. $)$ in THF $(2.5 \mathrm{~mL})$ at $0{ }^{\circ} \mathrm{C}$, $2 \mathrm{M} i \operatorname{Pr} \mathrm{MgCl}$ in THF (7.5 mL, $15 \mathrm{mmol}, 3.0$ equiv.) was added slowly. The resulting solution was allowed to warm to room temperature and stirred for $60 \mathrm{~min}$ to afford the 4-methyl-1-pentynyl magnesium chloride solution.

The freshly prepared 4-methyl-1-pentynyl magnesium chloride solution was slowly added into a solution of $N$-sulfinyl imine $\mathbf{S 1 q}\left(2.0126 \mathrm{~g}, 5.0 \mathrm{mmol}, 1.0\right.$ equiv.) in $\mathrm{CH}_{2} \mathrm{Cl}_{2}(25 \mathrm{~mL})$ via cannula 
at $-78{ }^{\circ} \mathrm{C}$ under argon protection. The resulting solution was stirred at $-78{ }^{\circ} \mathrm{C}$ for $2 \mathrm{~h}$, then gradually warmed to room temperature and stirred overnight. The reaction was quenched by saturated $\mathrm{NH}_{4} \mathrm{Cl}$ solution, followed by extraction with EtOAc three times. The combined organic layer was washed with brine, dried over $\mathrm{Na}_{2} \mathrm{SO}_{4}$, and the combined organic layer was concentrated under reduced pressure. The residue was purified by silica gel flash column chromatography (hexane/EtOAc $=$ 1/1) to afford $\mathbf{S 2 q}$ (1.8803 g, $3.87 \mathrm{mmol}, 77 \%$ yield) as a colorless oil.

4M HCl solution in dioxane (16 mmol, $4.0 \mathrm{~mL}, 4.0$ equiv.) was added into a solution of $\mathbf{S 2 q}$ $(1.8803 \mathrm{~g}, 3.87 \mathrm{mmol})$ in $\mathrm{MeOH}(20 \mathrm{~mL})$. The reaction mixture was stirred at room temperature for $30 \mathrm{~min}$. The solvent was removed under reduced pressure to afford crude product $\mathbf{S 3 q}$, which was directly used in the next step without further purification. Crude product S3q was dissolved in $20 \mathrm{~mL} \mathrm{CH} \mathrm{Cl}_{2}$ at $0{ }^{\circ} \mathrm{C}$, followed by the addition of $\mathrm{Et}_{3} \mathrm{~N}(2.72 \mathrm{~mL}, 19.35 \mathrm{mmol}, 5$ equiv.) and $\mathrm{TsCl}$ (885 mg, $4.64 \mathrm{mmol}, 1.2$ equiv.). The resulting mixture was allowed to warm to room temperature and stirred overnight. The reaction was quenched with saturated $\mathrm{NH}_{4} \mathrm{Cl}$ solution and extracted by $\mathrm{CH}_{2} \mathrm{Cl}_{2}$ three times. The combined organic layer was washed with brine, dried over $\mathrm{Na}_{2} \mathrm{SO}_{4}$, and concentrated under reduced pressure. The residue was purified by silica gel flash column chromatography (hexane/EtOAc $=5 / 1$ ) to afford a light-yellow solid. The product was further purified by recrystallization from hexane to afford 1q (947.8 mg, $1.77 \mathrm{mmol}$, 46\% yield) as a white needle.

${ }^{1}$ H NMR (600 MHz, CDCl 3$) \delta 7.90(\mathrm{~d}, J=8.4 \mathrm{~Hz}, 1 \mathrm{H}), 7.78-7.71(\mathrm{~m}, 5 \mathrm{H}), 7.57$ (s, 1H), 7.33 $7.29(\mathrm{~m}, 1 \mathrm{H}), 7.25-7.20(\mathrm{~m}, 5 \mathrm{H}), 5.53-5.47(\mathrm{~m}, 1 \mathrm{H}), 4.65(\mathrm{~d}, J=9.1 \mathrm{~Hz}, 1 \mathrm{H}), 2.41(\mathrm{~s}, 3 \mathrm{H}), 2.35$ (s, 3H), $1.89-1.84(\mathrm{~m}, 2 \mathrm{H}), 1.56$ (non, $J=6.6 \mathrm{~Hz}, 1 \mathrm{H}), 0.84(\mathrm{~d}, J=6.7 \mathrm{~Hz}, 6 \mathrm{H}) .{ }^{13} \mathrm{C}$ NMR (101 MHz, $\left.\mathbf{C D C l}_{3}\right) \delta 145.1,143.4,137.2,135.4,135.0,129.9,129.4,128.0,127.4,126.8,125.03$, 124.95, 123.4, 120.5, 120.0, 113.4, 85.4, 76.5, 42.6, 27.67, 27.62, 21.91, 21.89, 21.54, 21.47. HRMS (ESI) $m / z:[\mathrm{M}+\mathrm{Na}]^{+}$calcd for $\mathrm{C}_{29} \mathrm{H}_{30} \mathrm{~N}_{2} \mathrm{O}_{4} \mathrm{~S}_{2} \mathrm{Na}$ 557.1545; Found $m / z$ 557.1559.

\section{$(R, E)-4-M e t h y l-N$-(7-methyl-1-phenyloct-1-en-4-yn-3-yl)benzenesulfonamide (1r)}

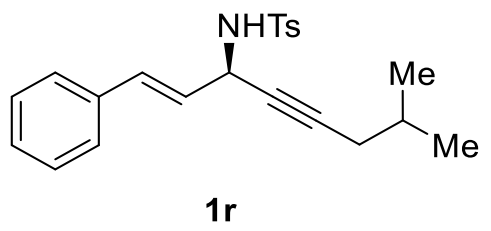

Compound 1r was synthesized according to General Procedure A. 

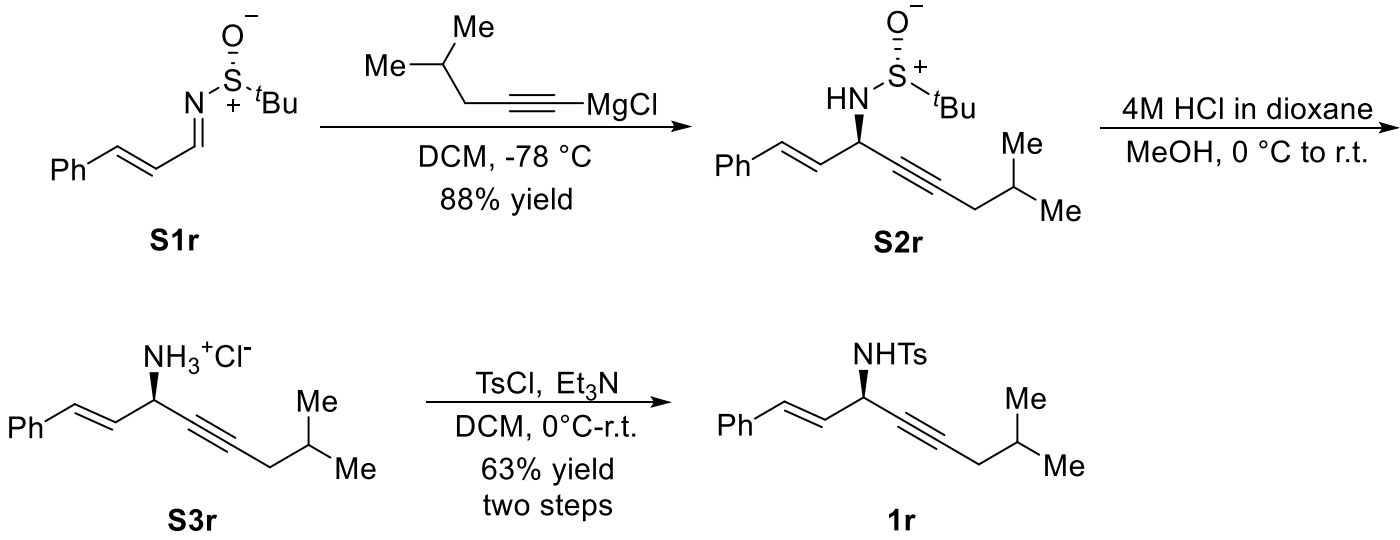

To a solution of 4-methyl-1-pentyne (1.94 mL, $16.5 \mathrm{mmol}, 3.3$ equiv.) in THF $(2.5 \mathrm{~mL})$ at $0{ }^{\circ} \mathrm{C}$, 2M iPr MgCl in THF (7.5 mL, $15 \mathrm{mmol}, 3.0$ equiv.) was added slowly. The resulting solution was allowed to warm to room temperature and stirred for 60 min to afford the 4-methyl-1-pentynyl magnesium chloride solution.

The freshly prepared 4-methyl-1-pentynyl magnesium chloride solution was slowly added into a solution of $N$-sulfinyl imine $\mathbf{S 1 r}\left(1.1767 \mathrm{~g}, 5.0 \mathrm{mmol}, 1.0\right.$ equiv.) in $\mathrm{CH}_{2} \mathrm{Cl}_{2}(20 \mathrm{~mL})$ via cannula at $-78{ }^{\circ} \mathrm{C}$ under argon protection. The resulting solution was stirred at $-78{ }^{\circ} \mathrm{C}$ for $2 \mathrm{~h}$, then gradually warmed to room temperature and stirred overnight. The reaction was quenched by saturated $\mathrm{NH}_{4} \mathrm{Cl}$ solution, followed by extraction with EtOAc three times. The combined organic layer was washed with brine, dried over $\mathrm{Na}_{2} \mathrm{SO}_{4}$, and the combined organic layer was concentrated under reduced pressure. The residue was purified by silica gel flash column chromatography (hexane/EtOAc = 3/1) to afford S2r (1.4027 g, $4.42 \mathrm{mmol}, 88 \%$ yield) as a colorless oil.

4M HCl solution in dioxane (17.6 mmol, $4.4 \mathrm{~mL}, 4.0$ equiv.) was added into a solution of $\mathbf{S 2 r}$ $(1.4027 \mathrm{~g}, 4.42 \mathrm{mmol})$ in $\mathrm{MeOH}(22 \mathrm{~mL})$. The reaction mixture was stirred at room temperature for $30 \mathrm{~min}$. The solvent was removed under reduced pressure to afford crude product $\mathbf{S 3 r}$, which was directly used in the next step without further purification. Crude product S3r was dissolved in $20 \mathrm{~mL} \mathrm{CH}_{2} \mathrm{Cl}_{2}$ at $0{ }^{\circ} \mathrm{C}$, followed by the addition of $\mathrm{Et}_{3} \mathrm{~N}$ (3.1 mL, $22.1 \mathrm{mmol}, 5$ equiv.) and $\mathrm{TsCl}$ (885 mg, $5.30 \mathrm{mmol}, 1.2$ equiv.). The resulting mixture was allowed to warm to room temperature and stirred overnight. The reaction was quenched with saturated $\mathrm{NH}_{4} \mathrm{Cl}$ solution and extracted by $\mathrm{CH}_{2} \mathrm{Cl}_{2}$ three times. The combined organic layer was washed with brine, dried over $\mathrm{Na}_{2} \mathrm{SO}_{4}$, and concentrated under reduced pressure. The residue was purified by silica gel flash column chromatography (hexane/EtOAc $=8 / 1$ ) to afford a light-yellow solid. The product was further 
purified by recrystallization from hexane to afford $1 \mathbf{r}(842.7 \mathrm{mg}, 2.77 \mathrm{mmol}, 63 \%$ yield $)$ as a white needle.

${ }^{1} \mathbf{H}$ NMR $\left(600 \mathbf{M H z} \mathbf{C D C l}_{3}\right) \delta 7.76(\mathrm{~d}, J=8.3 \mathrm{~Hz}, 2 \mathrm{H}), 7.31-7.17(\mathrm{~m}, 7 \mathrm{H}), 6.69(\mathrm{dd}, J=15.7$, $1.7 \mathrm{~Hz}, 1 \mathrm{H}), 6.04(\mathrm{dd}, J=15.7,5.3 \mathrm{~Hz}, 1 \mathrm{H}), 4.90-4.83(\mathrm{~m}, 1 \mathrm{H}), 4.64(\mathrm{~d}, J=8.8 \mathrm{~Hz}, 1 \mathrm{H}), 2.37$ (s, 3H), $1.86(\mathrm{dd}, J=6.9,2.1 \mathrm{~Hz}, 2 \mathrm{H}), 1.60$ (non, $J=6.7 \mathrm{~Hz}, 1 \mathrm{H}), 0.84(\mathrm{~d}, J=6.7 \mathrm{~Hz}, 4 \mathrm{H}) .{ }^{13} \mathrm{C}$ NMR (101 MHz, CDCl3) $\delta 143.4,137.6,135.8,132.4,129.5,128.5,128.1,127.4,126.7,126.0$, 86.4, 76.5, 47.6, 27.71, 27.69, 21.9, 21.5. HRMS (ESI) $\mathrm{m} / z:[\mathrm{M}+\mathrm{Na}]^{+}$calcd for $\mathrm{C}_{22} \mathrm{H}_{25} \mathrm{NO}_{2} \mathrm{SNa}$ 390.1504; Found $m / z 390.1503$.

\section{$N$-(1-(hex-1-yn-1-yl)cyclohexyl)-4-Methylbenzenesulfonamide (1s)}

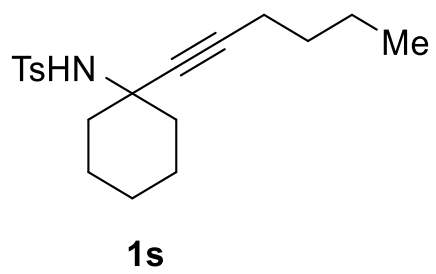

Compound 1s was synthesized according to General Procedure A.<smiles>[O-][SH](=[OH+])=NC1CCCCC1</smiles>

S1s

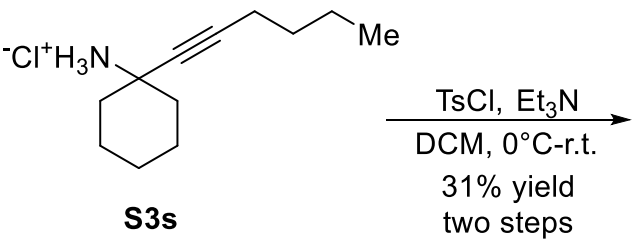

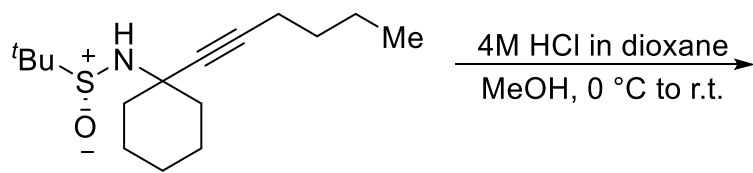

S2s

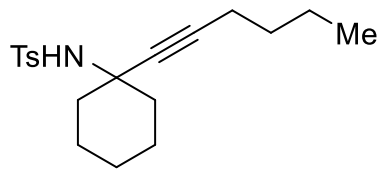

1s

To a solution of 1-hexyne $(0.61 \mathrm{~mL}, 5.28 \mathrm{mmol}, 2.2$ equiv. $)$ in $\mathrm{THF}(1.0 \mathrm{~mL})$ at $0{ }^{\circ} \mathrm{C}, 2 \mathrm{M} i \operatorname{Pr} \mathrm{MgCl}$ in THF (2.4 mL, $4.8 \mathrm{mmol}, 2.0$ equiv.) was added slowly. The resulting solution was allowed to warm to room temperature and stirred for $60 \mathrm{~min}$ to afford the 1-hexynyl magnesium chloride solution.

The freshly prepared 1-hexynyl magnesium chloride solution was slowly added into a solution of $N$-sulfinyl imine S1s (483.2 mg, $2.4 \mathrm{mmol}, 1.0$ equiv.) in $\mathrm{CH}_{2} \mathrm{Cl}_{2}(10 \mathrm{~mL})$ via cannula at $-78{ }^{\circ} \mathrm{C}$ 
under argon protection. The resulting solution was stirred at $-78^{\circ} \mathrm{C}$ for $2 \mathrm{~h}$, then gradually warmed to room temperature and stirred overnight. The reaction was quenched by saturated $\mathrm{NH}_{4} \mathrm{Cl}$ solution, followed by extraction with EtOAc three times. The combined organic layer was washed with brine, dried over $\mathrm{Na}_{2} \mathrm{SO}_{4}$, and the combined organic layer was concentrated under reduced pressure. The residue was purified by silica gel flash column chromatography (hexane/EtOAc $=3 / 1$ ) to afford S2s (453.6 mg, $1.60 \mathrm{mmol}, 67 \%$ yield) as a colorless oil.

4M HCl solution in dioxane $(6.4 \mathrm{mmol}, 1.6 \mathrm{~mL}, 4.0$ equiv.) was added into a solution of $\mathbf{S 2 s}$ (453.6 $\mathrm{mg}, 1.6 \mathrm{mmol})$ in $\mathrm{MeOH}(8 \mathrm{~mL})$. The reaction mixture was stirred at room temperature for $30 \mathrm{~min}$. The solvent was removed under reduced pressure to afford crude product $\mathbf{S 3}$, which was directly used in the next step without further purification. Crude product S3s was dissolved in $10 \mathrm{~mL}$ $\mathrm{CH}_{2} \mathrm{Cl}_{2}$ at $0{ }^{\circ} \mathrm{C}$, followed by the addition of $\mathrm{Et}_{3} \mathrm{~N}$ (1.1 mL, $8 \mathrm{mmol}, 5$ equiv.) and $\mathrm{TsCl}$ (336.0 mg, $1.92 \mathrm{mmol}, 1.2$ equiv.). The resulting mixture was allowed to warm to room temperature and stirred overnight. The reaction was quenched with saturated $\mathrm{NH}_{4} \mathrm{Cl}$ solution and extracted by $\mathrm{CH}_{2} \mathrm{Cl}_{2}$ three times. The combined organic layer was washed with brine, dried over $\mathrm{Na}_{2} \mathrm{SO}_{4}$, and concentrated under reduced pressure. The residue was purified by silica gel flash column chromatography (hexane/EtOAc $=20 / 1-$ hexane/EtOAc $=10 / 1)$ to afford $1 \mathrm{~s}(168.3 \mathrm{mg}, 0.50$ mmol, $31 \%$ yield) as a light-yellow oil.

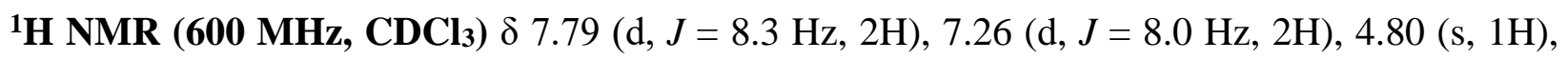
$2.40(\mathrm{~s}, 3 \mathrm{H}), 2.02-1.89(\mathrm{~m}, 2 \mathrm{H}), 1.81(\mathrm{t}, J=6.9 \mathrm{~Hz}, 2 \mathrm{H}), 1.67-1.56(\mathrm{~m}, 4 \mathrm{H}), 1.56-1.48(\mathrm{~m}$, 3H), $1.28-1.13(\mathrm{~m}, 5 \mathrm{H}), 0.84(\mathrm{t}, J=7.0 \mathrm{~Hz}, 3 \mathrm{H}) .{ }^{13} \mathbf{C} \mathbf{N M R}\left(\mathbf{1 2 6} \mathbf{M H z}, \mathbf{C D C l}_{3}\right) \delta 142.6,139.5$, 129.0, 127.6, 86.5, 79.8, 54.7, 39.3, 30.5, 25.0, 22.54, 21.9, 21.4, 18.2, 13.5. HRMS (ESI) $m / z$ : $[\mathrm{M}+\mathrm{Na}]^{+}$calcd for $\mathrm{C}_{19} \mathrm{H}_{27} \mathrm{NO}_{2} \mathrm{SNa} 356.1660$; Found $m / z$ 356.1659.

$N$-(1,1-diphenylhept-2-yn-1-yl)-4-Methylbenzenesulfonamide (1t)

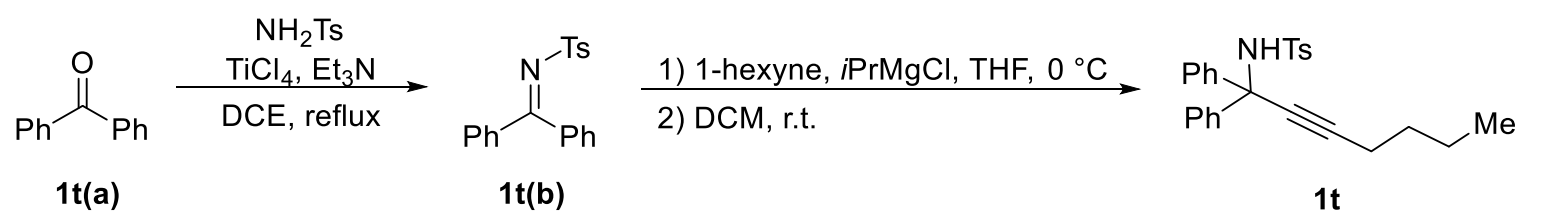

Compound 1t was synthesized according to a literature procedure ${ }^{8}$. White solid, 52\% yield (two steps overall). ${ }^{1} \mathbf{H}$ NMR (400 MHz, $\left.\mathbf{C D C l}_{3}\right) \delta 7.63(\mathrm{~d}, J=8.0 \mathrm{~Hz}, 2 \mathrm{H}), 7.56-7.44$ (m, 4H), 7.34 $-7.15(\mathrm{~m}, 8 \mathrm{H}), 5.35(\mathrm{~s}, 1 \mathrm{H}), 2.42(\mathrm{~s}, 3 \mathrm{H}), 2.05(\mathrm{t}, J=6.8 \mathrm{~Hz}, 2 \mathrm{H}), 1.43-1.27(\mathrm{~m}, 4 \mathrm{H}), 0.88(\mathrm{t}, J$ 
$=7.0 \mathrm{~Hz}, 3 \mathrm{H}) .{ }^{13} \mathbf{C}$ NMR (101 MHz, CDCl 3$) \delta 143.1,142.6,139.1,128.9,128.1,127.7,127.4$, 127.0, 90.0, 79.2, 63.1, 30.3, 22.0, 21.4, 18.5, 13.6. HRMS (ESI) $m / z:[\mathrm{M}+\mathrm{Na}]^{+}$calcd for $\mathrm{C}_{26} \mathrm{H}_{27} \mathrm{NO}_{2} \mathrm{SNa} 417.1762$; Found $m / z$ 417.1755.

4-Methyl-N-(tridec-2-yn-1-yl)benzenesulfonamide (1u)

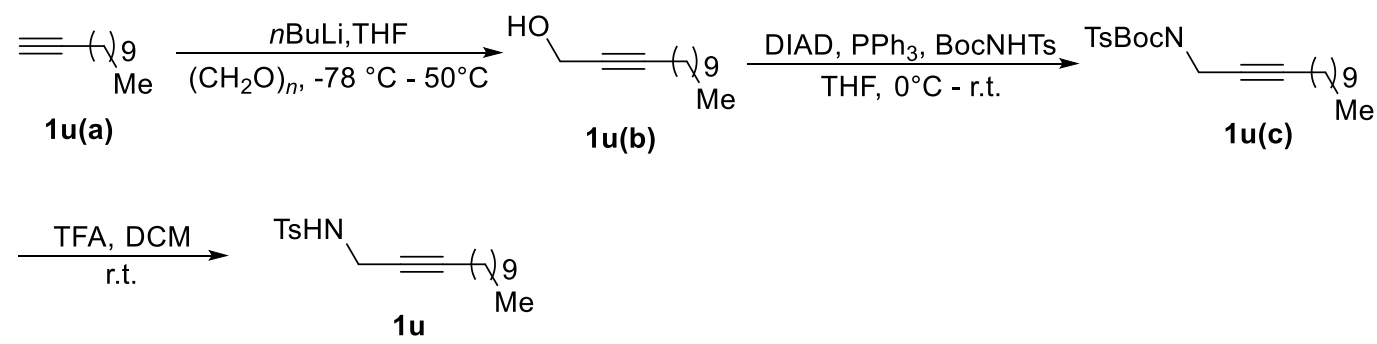

Compound $1 \mathbf{u}$ was synthesized according to a literature procedure ${ }^{9}$. White solid, $65 \%$ yield (three steps overall). ${ }^{1} \mathbf{H}$ NMR (500 MHz, CDCl$) \delta 7.77(\mathrm{~d}, J=8.3 \mathrm{~Hz}, 2 \mathrm{H}), 7.30(\mathrm{~d}, J=7.8 \mathrm{~Hz}, 2 \mathrm{H})$, $4.52(\mathrm{t}, J=6.0 \mathrm{~Hz}, 1 \mathrm{H}), 3.80(\mathrm{dt}, J=6.0,2.3 \mathrm{~Hz}, 2 \mathrm{H}), 2.42(\mathrm{~s}, 3 \mathrm{H}), 1.94(\mathrm{tt}, J=7.1,2.2 \mathrm{~Hz}, 2 \mathrm{H})$, $1.35-1.16(\mathrm{~m}, 16 \mathrm{H}), 0.88(\mathrm{t}, J=7.0 \mathrm{~Hz}, 3 \mathrm{H}) .{ }^{13} \mathbf{C}$ NMR (126 MHz, CDCl3) $\delta 143.5,136.9,129.6$, 127.4 , 85.6, 74.0, 33.5 , 31.9, 29.6, 29.5, 29.3, 29.1, 28.8, 28.3, 22.7 , 21.5, 18.5, 14.1. HRMS (ESI) $m / z:[\mathrm{M}+\mathrm{Na}]^{+}$calcd for $\mathrm{C}_{20} \mathrm{H}_{31} \mathrm{NO}_{2} \mathrm{SNa} 372.1973$; Found $m / z$ 372.1958.

(R)-N-(1-cyclopropylbut-2-yn-1-yl)-4-Methylbenzenesulfonamide (1v)

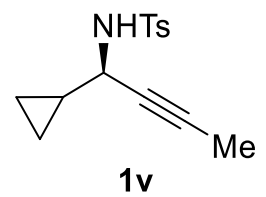

Compound 1v was synthesized according to General Procedure A.

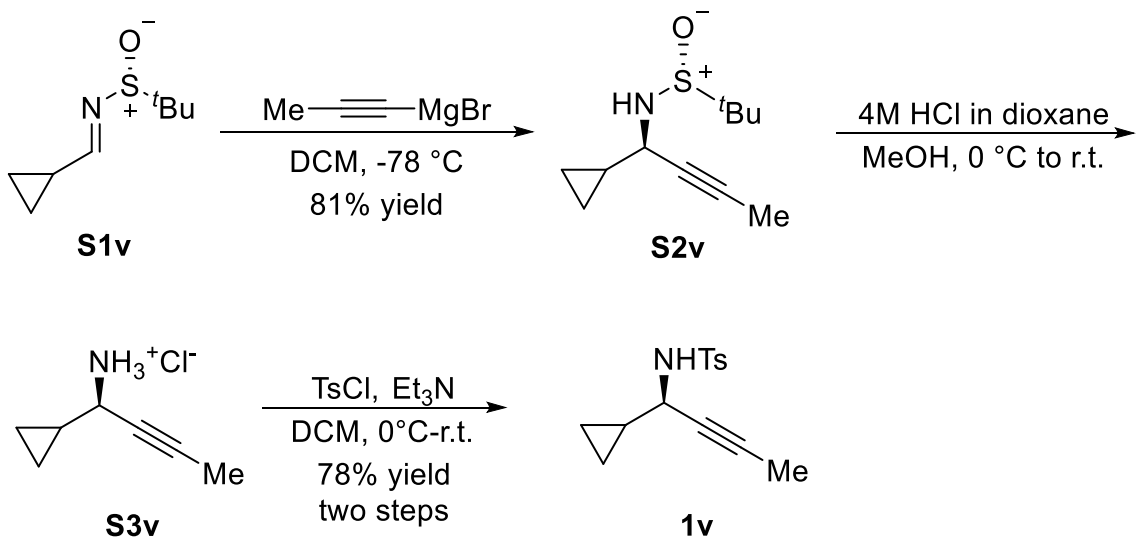


The 1-propynylmagnesium bromide solution (20 mL, $10 \mathrm{mmol}, 0.5 \mathrm{M}$ in THF) was slowly added into a solution of $\mathrm{N}$-sulfinyl imine $\mathbf{S 1 v}\left(866.3 \mathrm{~g}, 5.0 \mathrm{mmol}, 1.0\right.$ equiv.) in $\mathrm{CH}_{2} \mathrm{Cl}_{2}(25 \mathrm{~mL})$ via cannula at $-78^{\circ} \mathrm{C}$ under argon protection. The resulting solution was stirred at $-78{ }^{\circ} \mathrm{C}$ for $2 \mathrm{~h}$, then gradually warmed to room temperature and stirred overnight. The reaction was quenched by saturated $\mathrm{NH}_{4} \mathrm{Cl}$ solution, followed by extraction with EtOAc three times. The combined organic layer was washed with brine, dried over $\mathrm{Na}_{2} \mathrm{SO}_{4}$, and the combined organic layer was concentrated under reduced pressure. The residue was purified by silica gel flash column chromatography (hexane/EtOAc = 3/1) to afford S2v $(868.2 \mathrm{mg}, 4.07 \mathrm{mmol}, 81 \%$ yield) as a colorless oil (diastereomers are inseparable using the column chromatography, causing relatively low ee value for $1 \mathbf{v})$.

4M HCl solution in dioxane (16.0 mmol, $4.0 \mathrm{~mL}, 4.0$ equiv.) was added into a solution of $\mathbf{S 2 v}$ $(868.2 \mathrm{~g}, 4.07 \mathrm{mmol})$ in $\mathrm{MeOH}(20 \mathrm{~mL})$. The reaction mixture was stirred at room temperature for $30 \mathrm{~min}$. The solvent was removed under reduced pressure to afford crude product $\mathbf{S 3 \mathbf { v }}$, which was directly used in the next step without further purification. Crude product $\mathbf{S 3 v}$ was dissolved in 20 $\mathrm{mL} \mathrm{CH}_{2} \mathrm{Cl}_{2}$ at $0{ }^{\circ} \mathrm{C}$, followed by the addition of $\mathrm{Et}_{3} \mathrm{~N}(2.81 \mathrm{~mL}, 20.3 \mathrm{mmol}, 5$ equiv. $)$ and $\mathrm{TsCl}$ (931 mg, $4.88 \mathrm{mmol}, 1.2$ equiv.). The resulting mixture was allowed to warm to room temperature and stirred overnight. The reaction was quenched with saturated $\mathrm{NH}_{4} \mathrm{Cl}$ solution and extracted by $\mathrm{CH}_{2} \mathrm{Cl}_{2}$ three times. The combined organic layer was washed with brine, dried over $\mathrm{Na}_{2} \mathrm{SO}_{4}$, and concentrated under reduced pressure. The residue was purified by silica gel flash column chromatography (hexane/EtOAc $=5 / 1$ ) to afford a light-yellow solid. The product was further purified by recrystallization from hexane to afford $\mathbf{1 v}(838.7 \mathrm{mg}, 3.19 \mathrm{mmol}, 78 \%$ yield $)$ as a white needle.

${ }^{1}$ H NMR (600 MHz, CDCl 3$) \delta 7.78(\mathrm{~d}, J=8.3 \mathrm{~Hz}, 2 \mathrm{H}), 7.29(\mathrm{~d}, J=8.1 \mathrm{~Hz}, 2 \mathrm{H}), 4.70(\mathrm{~d}, J=8.8$ $\mathrm{Hz}, 1 \mathrm{H}), 4.04(\mathrm{ddq}, J=8.3,6.3,2.2 \mathrm{~Hz}, 1 \mathrm{H}), 2.41(\mathrm{~s}, 3 \mathrm{H}), 1.50(\mathrm{~d}, J=2.3 \mathrm{~Hz}, 3 \mathrm{H}), 1.11-1.05$ $(\mathrm{m}, 1 \mathrm{H}), 0.46-0.40(\mathrm{~m}, 2 \mathrm{H}), 0.40-0.34(\mathrm{~m}, 2 \mathrm{H}) .{ }^{13} \mathbf{C} \mathbf{N M R}\left(\mathbf{1 0 1} \mathbf{M H z}, \mathbf{C D C l}_{3}\right) \delta$ 143.2, 137.6, 129.3, 127.4, 81.0, 74.5, 49.1, 21.5, 15.7, 3.2, 3.0, 1.6. HRMS (ESI) $m / z:[\mathrm{M}+\mathrm{Na}]^{+}$calcd for $\mathrm{C}_{14} \mathrm{H}_{17} \mathrm{NO}_{2} \mathrm{SNa}$ 286.0878; Found $m / z$ 286.0878. 90\% e e ; HPLC(IC, Hexane/iPrOH = 90/10, flow rate $=1.0 \mathrm{~mL} / \mathrm{min}, \lambda=200 \mathrm{~nm}) \mathrm{t}_{\mathrm{R}}=32.15 \mathrm{~min}($ major $), \mathrm{t}_{\mathrm{R}}=29.18 \mathrm{~min}($ minor $\left.)\right]$

\section{(R)-4-Methyl- $N$-(1-phenyldodec-3-yn-5-yl)benzenesulfonamide (1w)}




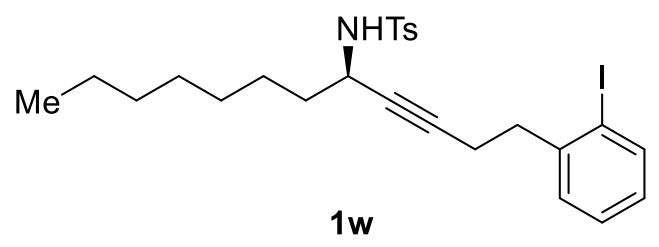

Compound 1w was synthesized according to General Procedure A.
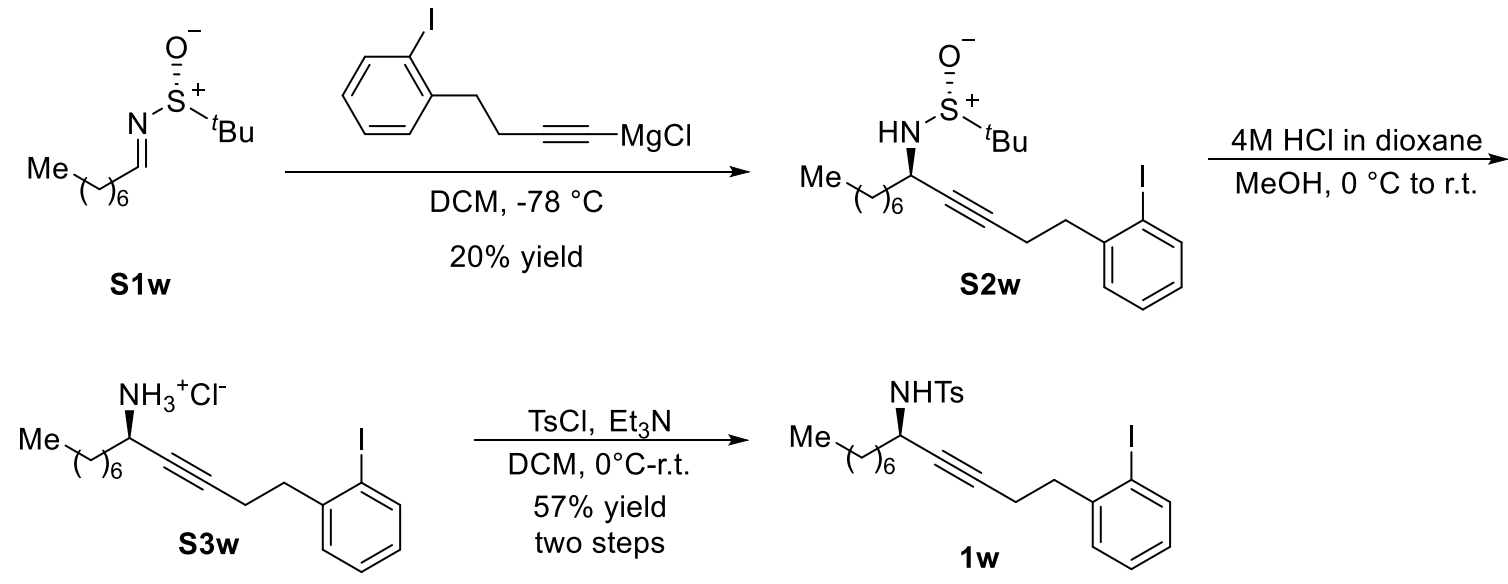

To a solution of 4-(2-iodo-1-phenyl)-1-butyne (5.63 g, $22 \mathrm{mmol}, 2.2$ equiv.) in THF (3.0 mL) at $0{ }^{\circ} \mathrm{C}, 2 \mathrm{M}$ iPrMgCl in THF (10.0 mL, $20 \mathrm{mmol}, 2.0$ equiv.) was added slowly. The resulting solution was allowed to warm to room temperature and stirred for $60 \mathrm{~min}$ to afford the 4-(2-iodo1-phenyl)-1-butynyl magnesium chloride solution.

The freshly prepared 4-(2-iodo-1-phenyl)-1-butynyl magnesium chloride solution was slowly added into a solution of $N$-sulfinyl imine $\mathbf{S 1 w}\left(2.31 \mathrm{~g}, 10 \mathrm{mmol}, 1.0\right.$ equiv.) in $\mathrm{CH}_{2} \mathrm{Cl}_{2}(50 \mathrm{~mL})$ via cannula at $-78{ }^{\circ} \mathrm{C}$ under argon protection. The resulting solution was stirred at $-78{ }^{\circ} \mathrm{C}$ for $2 \mathrm{~h}$, then gradually warmed to room temperature and stirred overnight. The reaction was quenched by saturated $\mathrm{NH}_{4} \mathrm{Cl}$ solution, followed by extraction with EtOAc three times. The combined organic layer was washed with brine, dried over $\mathrm{Na}_{2} \mathrm{SO}_{4}$, and the combined organic layer was concentrated under reduced pressure. The residue was purified by silica gel flash column chromatography (hexane/EtOAc = 3/1-2/1) to afford S2w $(996.5 \mathrm{mg}, 2.04 \mathrm{mmol}, 20 \%$ yield) as a colorless oil.

$2 \mathrm{M} \mathrm{HCl}$ solution in $\mathrm{Et}_{2} \mathrm{O}$ (8 mmol, $4.0 \mathrm{~mL}, 4.0$ equiv.) was added into a solution of $\mathbf{S 2} \mathbf{w}$ (996.5 $\mathrm{mg}, 2.04 \mathrm{mmol})$ in $\mathrm{MeOH}(10 \mathrm{~mL})$. The reaction mixture was stirred at room temperature for 30 min. The solvent was removed under reduced pressure to afford crude product $\mathbf{S 3 w}$, which was directly used in the next step without further purification. Crude product $\mathbf{S 3}$ w was dissolved in 10 
$\mathrm{mL} \mathrm{CH}_{2} \mathrm{Cl}_{2}$ at $0{ }^{\circ} \mathrm{C}$, followed by the addition of $\mathrm{Et}_{3} \mathrm{~N}$ (1.42 mL, $10.0 \mathrm{mmol}, 5$ equiv.) and $\mathrm{TsCl}$ (467 mg, $2.44 \mathrm{mmol}, 1.0$ equiv.). The resulting mixture was allowed to warm to room temperature and stirred overnight. The reaction was quenched with saturated $\mathrm{NH}_{4} \mathrm{Cl}$ solution and extracted by $\mathrm{CH}_{2} \mathrm{Cl}_{2}$ three times. The combined organic layer was washed with brine, dried over $\mathrm{Na}_{2} \mathrm{SO}_{4}$, and concentrated under reduced pressure. The residue was purified by silica gel flash column chromatography (hexane/EtOAc $=10 / 1)$ to afford a light-yellow solid. The product was further purified by recrystallization from hexane to afford $\mathbf{1 w}(631.7 \mathrm{mg}, 1.18 \mathrm{mmol}, 58 \%$ yield $)$ as a white needle.

${ }^{1}$ H NMR (500 MHz, CDCl 3$) \delta 7.81(\mathrm{dd}, J=7.9,1.2 \mathrm{~Hz}, 1 \mathrm{H}), 7.71(\mathrm{~d}, J=8.3 \mathrm{~Hz}, 2 \mathrm{H}), 7.26$ (ddt, $J=5.2,3.6,2.1 \mathrm{~Hz}, 3 \mathrm{H}), 7.12(\mathrm{dd}, J=7.6,1.7 \mathrm{~Hz}, 1 \mathrm{H}), 6.91(\mathrm{td}, J=7.6,1.7 \mathrm{~Hz}, 1 \mathrm{H}), 4.45(\mathrm{~d}, J=$ $9.1 \mathrm{~Hz}, 1 \mathrm{H}), 4.00(\mathrm{dtt}, J=9.0,6.8,2.1 \mathrm{~Hz}, 1 \mathrm{H}), 2.67$ (t, $J=7.4 \mathrm{~Hz}, 2 \mathrm{H}), 2.41(\mathrm{~s}, 3 \mathrm{H}), 2.19$ (tt, $J=$ 7.5, $2.1 \mathrm{~Hz}, 2 \mathrm{H}), 1.63-1.54(\mathrm{~m}, 2 \mathrm{H}), 1.41-1.14(\mathrm{~m}, 10 \mathrm{H}), 0.88(\mathrm{t}, J=7.0 \mathrm{~Hz}, 3 \mathrm{H}) .{ }^{13} \mathbf{C}$ NMR (126 MHz, CDCl $) \delta 143.2,142.7,139.5,137.5,129.8,129.4,128.3,128.2,127.4,100.3,83.4$, 79.4, 46.0, 39.4, 36.9 31.7, 29.1, 28.9, 25.3, 22.6, 21.6, 19.0, 14.1. HRMS (ESI) $m / z:[\mathrm{M}+\mathrm{Na}]^{+}$ calcd for $\mathrm{C}_{25} \mathrm{H}_{32} \mathrm{INO}_{2} \mathrm{SNa} 560.1096$; Found $m / z$ 560.1080.

(R)-4-Methyl- $N$-(1-phenyldodec-3-yn-5-yl)benzenesulfonamide (1x)

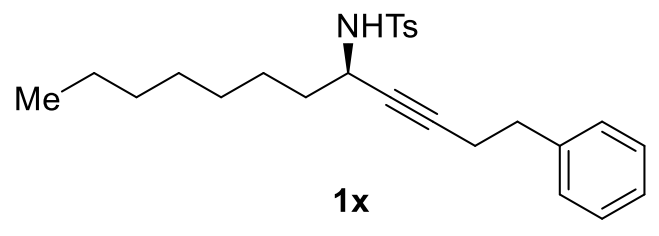

Compound 1x was synthesized according to General Procedure A.

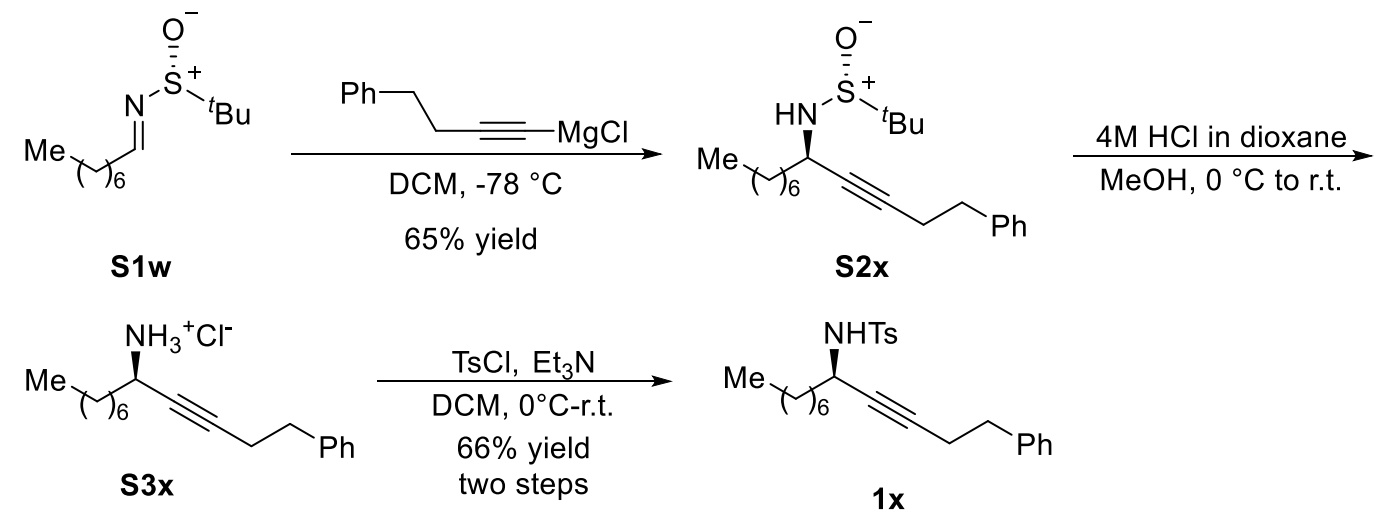


To a solution of 4-phenyl-1-butyne (3.1 mL, $22 \mathrm{mmol}, 2.2$ equiv.) in THF (3.0 mL) at $0{ }^{\circ} \mathrm{C}, 2 \mathrm{M}$ $i P r \mathrm{MgCl}$ in THF (10.0 mL, $20 \mathrm{mmol}, 2.0$ equiv.) was added slowly. The resulting solution was allowed to warm to room temperature and stirred for $60 \mathrm{~min}$ to afford the 4-phenyl-1-butynyl magnesium chloride solution.

The freshly prepared 4-phenyl-1-butynyl magnesium chloride solution was slowly added into a solution of $N$-sulfinyl imine $\mathbf{S 1 w}\left(2.31 \mathrm{~g}, 10 \mathrm{mmol}, 1.0\right.$ equiv.) in $\mathrm{CH}_{2} \mathrm{Cl}_{2}(50 \mathrm{~mL})$ via cannula at $-78{ }^{\circ} \mathrm{C}$ under argon protection. The resulting solution was stirred at $-78{ }^{\circ} \mathrm{C}$ for $2 \mathrm{~h}$, then gradually warmed to room temperature and stirred overnight. The reaction was quenched by saturated $\mathrm{NH}_{4} \mathrm{Cl}$ solution, followed by extraction with EtOAc three times. The combined organic layer was washed with brine, dried over $\mathrm{Na}_{2} \mathrm{SO}_{4}$, and the combined organic layer was concentrated under reduced pressure. The residue was purified by silica gel flash column chromatography (hexane/EtOAc = 3/1-2/1) to afford $\mathbf{S 2 x}$ (2.36 g, $6.53 \mathrm{mmol}, 65 \%$ yield) as a colorless oil.

4M HCl solution in dioxane (26.0 mmol, $6.5 \mathrm{~mL}, 4.0$ equiv.) was added into a solution of $\mathbf{S 2 x}$ $(2.36 \mathrm{~g}, 6.53 \mathrm{mmol})$ in $\mathrm{MeOH}(30 \mathrm{~mL})$. The reaction mixture was stirred at room temperature for $30 \mathrm{~min}$. The solvent was removed under reduced pressure to afford crude product $\mathbf{S 3} \mathbf{x}$, which was directly used in the next step without further purification. Crude product $\mathbf{S 3 x}$ was dissolved in 32 $\mathrm{mL} \mathrm{CH}_{2} \mathrm{Cl}_{2}$ at $0{ }^{\circ} \mathrm{C}$, followed by the addition of $\mathrm{Et}_{3} \mathrm{~N}(4.56 \mathrm{~mL}, 32.7 \mathrm{mmol}, 5$ equiv.) and $\mathrm{TsCl}$ (1.24 g, $6.5 \mathrm{mmol}, 1.0$ equiv.). The resulting mixture was allowed to warm to room temperature and stirred overnight. The reaction was quenched with saturated $\mathrm{NH}_{4} \mathrm{Cl}$ solution and extracted by $\mathrm{CH}_{2} \mathrm{Cl}_{2}$ three times. The combined organic layer was washed with brine, dried over $\mathrm{Na}_{2} \mathrm{SO}_{4}$, and concentrated under reduced pressure. The residue was purified by silica gel flash column chromatography (hexane/EtOAc $=7 / 1$ ) to afford a light-yellow solid. The product was further purified by recrystallization from hexane to afford $\mathbf{1 x}(1.76 \mathrm{~g}, 4.28 \mathrm{mmol}, 66 \%$ yield $)$ as a white needle.

${ }^{1}$ H NMR (500 MHz, CDCl 3$) \delta 7.74(\mathrm{~d}, J=8.0 \mathrm{~Hz}, 2 \mathrm{H}), 7.31-7.23(\mathrm{~m}, 4 \mathrm{H}), 7.23-7.17$ (m, 1H), $7.09(\mathrm{~d}, J=7.4 \mathrm{~Hz}, 2 \mathrm{H}), 4.55(\mathrm{~d}, J=9.0 \mathrm{~Hz}, 1 \mathrm{H}), 4.00(\mathrm{dt}, J=9.0,6.6 \mathrm{~Hz}, 1 \mathrm{H}), 2.55(\mathrm{t}, J=7.5$ $\mathrm{Hz}, 2 \mathrm{H}), 2.40$ (s, 3H), $2.17(\mathrm{tt}, J=7.6,2.0 \mathrm{~Hz}, 2 \mathrm{H}), 1.65-1.51(\mathrm{~m}, 2 \mathrm{H}), 1.42-1.12(\mathrm{~m}, 10 \mathrm{H})$, $0.88(\mathrm{t}, J=7.0 \mathrm{~Hz}, 3 \mathrm{H}) .{ }^{13} \mathbf{C}$ NMR (126 MHz, CDCl3) $\delta 143.1,140.4,137.6,129.3,128.30,128.28$, 127.4, 126.3, 84.1, 79.1, 46.0, 36.9, 34.7, 31.7, 29.0, 28.9, 25.3, 22.6, 21.5, 20.5, 14.0. HRMS (ESI) $m / z:[\mathrm{M}+\mathrm{Na}]^{+}$calcd for $\mathrm{C}_{25} \mathrm{H}_{33} \mathrm{NO}_{2} \mathrm{SNa}$ 434.2130; Found $\mathrm{m} / z$ 434.2129. 


\section{Synthesis of Compound 2}

\section{General Procedure B:}

To a 1-dram vial were added sequentially $0.2 \mathrm{mmol}$ sulfonamide $\mathbf{1}, 5 \mathrm{~mol} \%(\boldsymbol{S})-\mathbf{L} \mathbf{A u C l}(9.2 \mathrm{mg})$, $10 \mathrm{~mol} \% \mathrm{NaBAr}_{4} \mathrm{~F}_{4}(17.6 \mathrm{mg})$ and $0.4 \mathrm{~mL}$ dry toluene. The reaction was stirred at the indicated temperature using a heating block and monitored by TLC. Upon completion, the reaction mixture was concentrated under reduced pressure. The residue was purified by silica gel flash column chromatography to afford the desired product.

(2R,5S)-2-Methyl-5-propyl-1-tosyl-2,5-dihydro-1H-pyrrole (cis-2a)

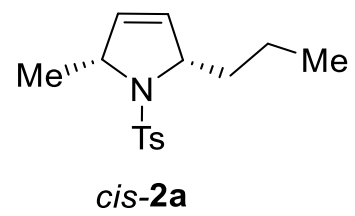

Following the general procedure B, $\mathbf{1 a}(0.2 \mathrm{mmol}, 56.7 \mathrm{mg}), 5 \mathrm{~mol} \%(\boldsymbol{S})-\mathbf{L} 1 \mathrm{AuCl}(9.2 \mathrm{mg}), 10$ $\mathrm{mol} \% \mathrm{NaBAr}_{4}{ }_{4}(17.6 \mathrm{mg})$ and $0.4 \mathrm{~mL}$ dry toluene were stirred at $110{ }^{\circ} \mathrm{C}$ for $14 \mathrm{~h}$. The solvent was removed, and the residue was purified by flash column chromatography (hexane/EtOAc $=15: 1$ ) to afford cis-2a as a white solid (52.7 mg, 93\% yield, d.r. $=97 / 3$ ). Crystals were obtained via slow evaporation of a solution of $\boldsymbol{c i s}-\mathbf{2} \boldsymbol{a}$ in DCM/hexanes (1/1) at room temperature. ${ }^{\mathbf{1}} \mathbf{H}$ NMR (600 MHz, $\left.\mathbf{C D C l}_{3}\right) \delta 7.70(\mathrm{~d}, J=8.3 \mathrm{~Hz}, 2 \mathrm{H}), 7.28(\mathrm{~d}, J=8.4 \mathrm{~Hz}, 2 \mathrm{H}), 5.52(\mathrm{dt}, J=6.2,1.7 \mathrm{~Hz}, 1 \mathrm{H})$, $5.49(\mathrm{dt}, J=6.2,1.8 \mathrm{~Hz}, 1 \mathrm{H}), 4.43-4.38(\mathrm{~m}, 1 \mathrm{H}), 4.38-4.33(\mathrm{~m}, 1 \mathrm{H}), 2.40(\mathrm{~s}, 3 \mathrm{H}), 1.86-1.75$ (m, $1 \mathrm{H}), 1.71-1.59(\mathrm{~m}, 1 \mathrm{H}), 1.50-1.39(\mathrm{~m}, 1 \mathrm{H}), 1.38(\mathrm{~d}, J=6.4 \mathrm{~Hz}, 3 \mathrm{H}), 1.37-1.23(\mathrm{~m}, 1 \mathrm{H})$, $0.94(\mathrm{t}, J=7.3 \mathrm{~Hz}, 3 \mathrm{H}) .{ }^{13} \mathbf{C} \mathbf{~ N M R}\left(\mathbf{1 2 6} \mathbf{~ M H z}, \mathbf{C D C l}_{3}\right) \delta 143.2,134.8,130.3,129.5,128.3,127.4$, $67.8,63.5,39.7,23.6,21.4,18.3,14.0$. These data are consistent with the literature ${ }^{10}$.

(2S,5R)-2-Benzyl-5-methyl-1-tosyl-2,5-dihydro-1H-pyrrole (cis-2b)

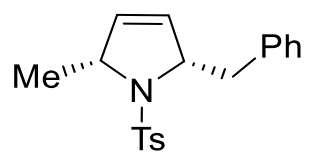

cis-2b

Following the general procedure B, $1 \mathbf{b}(0.2 \mathrm{mmol}, 65.2 \mathrm{mg}), 5 \mathrm{~mol} \%(\boldsymbol{S})-\mathrm{L1AuCl}(9.2 \mathrm{mg}), 10$ $\mathrm{mol} \% \mathrm{NaBAr}_{4}(17.6 \mathrm{mg})$ and $0.4 \mathrm{~mL}$ dry toluene were stirred at $110{ }^{\circ} \mathrm{C}$ for $20 \mathrm{~h}$. The solvent was 
removed, and the residue was purified by flash column chromatography (hexane/EtOAc $=15: 1)$ to afford cis-2b as a white solid $(62.5 \mathrm{mg}, 96 \%$ yield, $d . r .=96 / 4)$.

${ }^{1}$ H NMR (600 MHz, CDCl $) \delta 7.73(\mathrm{~d}, J=8.3 \mathrm{~Hz}, 2 \mathrm{H}), 7.33-7.27$ (m, 4H), 7.25 - 7.19 (m, 3H), $5.47-5.38(\mathrm{~m}, 2 \mathrm{H}), 4.61-4.55(\mathrm{~m}, 1 \mathrm{H}), 4.38-4.32(\mathrm{~m}, 1 \mathrm{H}), 3.25(\mathrm{dd}, J=13.2,3.3 \mathrm{~Hz}, 1 \mathrm{H})$, $2.94(\mathrm{dd}, J=13.1,8.5 \mathrm{~Hz}, 1 \mathrm{H}), 2.41(\mathrm{~s}, 3 \mathrm{H}), 1.04(\mathrm{~d}, J=6.5 \mathrm{~Hz}, 3 \mathrm{H}) .{ }^{\mathbf{1 3}} \mathbf{C} \mathbf{N M R}(\mathbf{1 5 1} \mathbf{M H z}, \mathbf{C D C l})$ $\delta 143.3,137.1,134.7,130.9,130.2,129.6,128.0,127.5,127.4,126.4,69.0,63.8,43.9,23.2,21.4$. HRMS (ESI) $m / z:[\mathrm{M}+\mathrm{Na}]^{+}$calcd for $\mathrm{C}_{19} \mathrm{H}_{21} \mathrm{NO}_{2} \mathrm{SNa} 350.1191$; Found $m / z 350.1184$.

(2S,5R)-2-Isopropyl-5-methyl-1-tosyl-2,5-dihydro-1H-pyrrole (cis-2c)

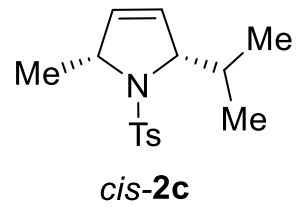

Following the general procedure B, $1 \mathrm{c}(0.2 \mathrm{mmol}, 55.9 \mathrm{mg}), 5 \mathrm{~mol} \%(\boldsymbol{S})-\mathbf{L} \mathbf{A u C l}(9.2 \mathrm{mg}), 10$ mol\% $\mathrm{NaBAr}_{4}(17.6 \mathrm{mg})$ and $0.4 \mathrm{~mL}$ dry toluene were stirred at $110{ }^{\circ} \mathrm{C}$ for $32 \mathrm{~h}$. The solvent was removed, and the residue was purified by flash column chromatography (hexane/EtOAc $=15: 1)$ to afford cis-2c as a white solid (48.5 mg, 87\% yield, d.r. $=98 / 2) .{ }^{1} \mathbf{H}$ NMR $(600 \mathrm{MHz}, \mathbf{C D C l} 3) \delta$ $7.69(\mathrm{~d}, J=8.2 \mathrm{~Hz}, 2 \mathrm{H}), 7.28(\mathrm{~d}, J=8.1 \mathrm{~Hz}, 2 \mathrm{H}), 5.51(\mathrm{dt}, J=6.2,1.8 \mathrm{~Hz}, 1 \mathrm{H}), 5.46(\mathrm{dt}, J=6.3$, $1.7 \mathrm{~Hz}, 1 \mathrm{H}), 4.41-4.35$ (m, 1H), $4.29-4.25$ (m, 1H), 2.40 (s, 3H), $2.21-2.11(\mathrm{~m}, 1 \mathrm{H}), 1.38$ (d, $J=6.5 \mathrm{~Hz}, 3 \mathrm{H}), 0.96(\mathrm{~d}, J=7.1 \mathrm{~Hz}, 3 \mathrm{H}), 0.86(\mathrm{~d}, J=6.8 \mathrm{~Hz}, 3 \mathrm{H}) .{ }^{13} \mathbf{C} \mathbf{N M R}(\mathbf{1 5 1} \mathbf{M H z}, \mathbf{C D C l})$ $\delta 143.2,134.6,131.2,129.6,127.5,124.9,73.6,63.8,32.6,22.9,21.4,19.6,16.6$. HRMS (ESI) $m / z:[\mathrm{M}+\mathrm{Na}]^{+}$calcd for $\mathrm{C}_{15} \mathrm{H}_{21} \mathrm{NO}_{2} \mathrm{SNa} 302.1191$; Found $m / z$ 302.1194.

(2S,5R)-2-Cyclohexyl-5-methyl-1-tosyl-2,5-dihydro-1H-pyrrole (cis-2d)

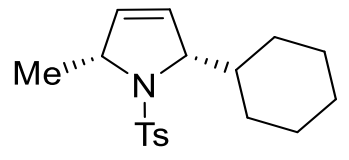

cis-2d

Following the general procedure B, 1 d $(0.2 \mathrm{mmol}, 63.9 \mathrm{mg}), 5 \mathrm{~mol} \%(\boldsymbol{S})-\mathrm{L1AuCl}(9.2 \mathrm{mg}), 10$ $\mathrm{mol} \% \mathrm{NaBAr}_{4}(17.6 \mathrm{mg})$ and $0.4 \mathrm{~mL}$ dry toluene were stirred at $110{ }^{\circ} \mathrm{C}$ for $20 \mathrm{~h}$. The solvent was removed, and the residue was purified by flash column chromatography (hexane/EtOAc $=15: 1$ ) to afford cis-2d as a white solid (58.6 mg, 93\% yield, d.r. $=98 / 2) .{ }^{1} \mathbf{H}$ NMR (600 MHz, CDCl3) 
$\delta 7.68(\mathrm{~d}, J=8.2 \mathrm{~Hz}, 2 \mathrm{H}), 7.27(\mathrm{~d}, J=8.0 \mathrm{~Hz}, 2 \mathrm{H}), 5.53-5.41(\mathrm{~m}, 2 \mathrm{H}), 4.42-4.34(\mathrm{~m}, 1 \mathrm{H}), 4.28$ $-4.23(\mathrm{~m}, 1 \mathrm{H}), 2.39(\mathrm{~s}, 3 \mathrm{H}), 1.85-1.72(\mathrm{~m}, 5 \mathrm{H}), 1.70-1.63(\mathrm{~m}, 1 \mathrm{H}), 1.36(\mathrm{~d}, J=6.5 \mathrm{~Hz}, 3 \mathrm{H})$, $1.32-1.19(\mathrm{~m}, 2 \mathrm{H}), 1.07$ (qt, $J=13.0,3.6 \mathrm{~Hz}, 1 \mathrm{H}), 0.97$ (qd, $J=13.1,3.8 \mathrm{~Hz}, 1 \mathrm{H}), 0.80(\mathrm{qd}, J=$ 12.7, $3.4 \mathrm{~Hz}, 1 \mathrm{H}) .{ }^{13} \mathbf{C}$ NMR (101 MHz, CDCl$) \delta ~ 143.2,134.4,130.7,129.5,127.5,125.8,73.0$, 63.5, 42.6, 30.3, 27.4, 26.5, 26.4, 25.9, 22.8, 21.5. HRMS (ESI) $\mathrm{m} / \mathrm{z}:[\mathrm{M}+\mathrm{Na}]^{+}$calcd for $\mathrm{C}_{18} \mathrm{H}_{25} \mathrm{NO}_{2} \mathrm{SNa}$ 342.1504; Found $\mathrm{m} / z 350.1513$.

(2S,5R)-2-(2-chloroethyl)-5-Methyl-1-tosyl-2,5-dihydro-1H-pyrrole (cis-2e)

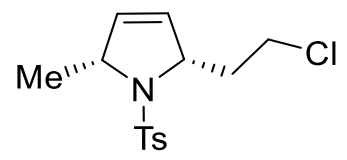

cis-2e

Following the general procedure B, $\mathbf{1 e}(0.2 \mathrm{mmol}, 60.0 \mathrm{mg}), 5 \mathrm{~mol} \%(\boldsymbol{S})-\mathbf{L 1 A u C l}(9.2 \mathrm{mg}), 10$ $\mathrm{mol} \% \mathrm{NaBAr}_{4}{ }_{4}(17.6 \mathrm{mg})$ and $0.4 \mathrm{~mL}$ dry toluene were stirred at $110{ }^{\circ} \mathrm{C}$ for $40 \mathrm{~h}$. The solvent was removed, and the residue was purified by flash column chromatography (hexane/EtOAc $=15: 1$ to hexane/EtOAc $=10 / 1)$ to afford $c i s-2 e$ as a white solid $(31.8 \mathrm{mg}, 53 \%$ yield, $88 \%$ yield based on recovery S.M., d.r. $=98 / 2)$ and recovery starting material 1e $(23.7 \mathrm{mg}) .{ }^{1} \mathbf{H}$ NMR $(600 \mathrm{MHz}$, $\left.\mathbf{C D C l}_{3}\right) \delta 7.70(\mathrm{~d}, J=8.2 \mathrm{~Hz}, 2 \mathrm{H}), 7.29(\mathrm{~d}, J=8.0 \mathrm{~Hz}, 2 \mathrm{H}), 5.58-5.49(\mathrm{~m}, 2 \mathrm{H}), 4.54-4.47(\mathrm{~m}$, $1 \mathrm{H}), 4.45-4.37(\mathrm{~m}, 1 \mathrm{H}), 3.76(\mathrm{dt}, J=11.0,6.9 \mathrm{~Hz}, 1 \mathrm{H}), 3.61(\mathrm{dt}, J=11.0,7.1 \mathrm{~Hz}, 1 \mathrm{H}), 2.41(\mathrm{~s}$, 3H), $2.24-2.12(\mathrm{~m}, 2 \mathrm{H}), 1.39$ (d, $J=6.5 \mathrm{~Hz}, 3 \mathrm{H}) .{ }^{13} \mathbf{C}$ NMR (101 MHz, $\left.\mathbf{C D C l}_{3}\right) \delta$ 143.6, 134.1, 131.2, 129.7, 127.52, 127.50, 65.6, 63.8, 41.2, 40.1, 23.8, 21.5. HRMS (ESI) $\mathrm{m} / z:[\mathrm{M}+\mathrm{Na}]^{+}$calcd for $\mathrm{C}_{14} \mathrm{H}_{18} \mathrm{ClNO}_{2} \mathrm{SNa} 322.0645$; Found $m / 2322.0648$.

(2R,5R)-2-(((tert-butyldiphenylsilyl)oxy)methyl)-5-Methyl-1-tosyl-2,5-dihydro-1H-pyrrole (cis-2f)

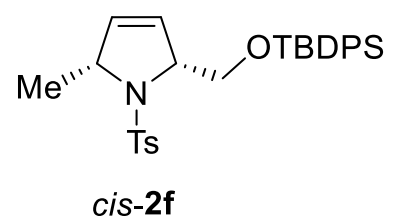

Following the general procedure B, $\mathbf{1 f}(0.2 \mathrm{mmol}, 60.0 \mathrm{mg}), 5 \mathrm{~mol} \%(\boldsymbol{S})-\mathbf{L 1 A u C l}(9.2 \mathrm{mg}), 10$ $\mathrm{mol} \% \mathrm{NaBAr}_{4} \mathrm{~F}_{4}(17.6 \mathrm{mg})$ and $0.4 \mathrm{~mL}$ dry toluene were stirred at $110{ }^{\circ} \mathrm{C}$ for $60 \mathrm{~h}$. The solvent was removed, and the residue was purified by flash column chromatography (hexane/EtOAc $=10: 1$ ) 
to afford cis-2f as a white solid (76.5 mg, 75\% yield, d.r. = 94 / 6). ${ }^{1} \mathbf{H}$ NMR (600 MHz, CDCl $)$ $\delta 7.74-7.58(\mathrm{~m}, 6 \mathrm{H}), 7.48-7.37(\mathrm{~m}, 6 \mathrm{H}), 7.29-7.23(\mathrm{~m}, 2 \mathrm{H}), 5.75-5.70(\mathrm{~m}, 1 \mathrm{H}), 5.62-5.53$ $(\mathrm{m}, 1 \mathrm{H}), 4.46-4.40(\mathrm{~m}, 1 \mathrm{H}), 4.38-4.33(\mathrm{~m}, 1 \mathrm{H}), 4.06(\mathrm{dd}, J=9.9,4.1 \mathrm{~Hz}, 1 \mathrm{H}), 3.68(\mathrm{dd}, J=9.9$, $7.6 \mathrm{~Hz}, 1 \mathrm{H}), 2.40(\mathrm{~s}, 3 \mathrm{H}), 1.37(\mathrm{~d}, J=6.5 \mathrm{~Hz}, 3 \mathrm{H}), 1.08(\mathrm{~s}, 9 \mathrm{H}) .{ }^{\mathbf{1 3}} \mathbf{C}$ NMR (101 MHz, CDCl$) \delta$ 143.3, 135.62, 135.58, 134.5, 133.4, 133.2, 131.4, 129.7, 129.63, 129.59, 127.7, 127.6, 127.4, 127.1, 68.4, 68.2, 63.9, 26.9, 23.7, 21.5, 19.2. HRMS (ESI) $m / z:[\mathrm{M}+\mathrm{Na}]^{+}$calcd for $\mathrm{C}_{29} \mathrm{H}_{35} \mathrm{NO}_{3} \mathrm{SSiNa}$ 528.2004; Found $m / z$ 528.1990.

2-(2-((2S,5R)-5-methyl-1-tosyl-2,5-dihydro-1H-pyrrol-2-yl)ethyl)Isoindoline-1,3-dione (cis2g)

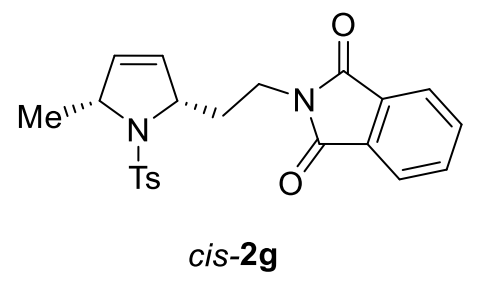

Following the general procedure B, $1 \mathrm{~g}(0.15 \mathrm{mmol}, 61.6 \mathrm{mg}), 5 \mathrm{~mol} \%(\mathrm{~S})-\mathrm{L1AuCl}$ (6.6 $\mathrm{mg}), 10$ mol\% $\mathrm{NaBAr}_{4}(13.2 \mathrm{mg})$ and $0.3 \mathrm{~mL}$ dry toluene were stirred at $110{ }^{\circ} \mathrm{C}$ for $24 \mathrm{~h}$. The solvent was removed, and the residue was purified by flash column chromatography (hexane/EtOAc $=4: 1$ ) to afford cis-2g as a white solid (49.6 mg, 81\% yield, d.r. = $96 / 4) .{ }^{1} \mathbf{H}$ NMR (500 MHz, CDCl3) $\delta$ $7.88-7.82(\mathrm{~m}, 2 \mathrm{H}), 7.74-7.70(\mathrm{~m}, 2 \mathrm{H}), 7.70-7.65(\mathrm{~m}, 2 \mathrm{H}), 7.28-7.23(\mathrm{~m}, 3 \mathrm{H}), 5.61(\mathrm{dt}, J=$ 6.3, 1.9 Hz, 1H), $5.56(\mathrm{dt}, J=6.1,1.9 \mathrm{~Hz}, 1 \mathrm{H}), 4.49-4.41(\mathrm{~m}, 2 \mathrm{H}), 3.87-3.77(\mathrm{~m}, 2 \mathrm{H}), 2.40$ (s, 3H), $2.20-2.13(\mathrm{~m}, 1 \mathrm{H}), 2.07-1.98(\mathrm{~m}, 1 \mathrm{H}), 1.39$ (d, $J=6.5 \mathrm{~Hz}, 3 \mathrm{H}) .{ }^{13} \mathrm{C}$ NMR (126 MHz, CDCl3) $\delta 168.2,143.4,134.6,133.9,132.1,131.4,129.6,127.6,127.5,123.2,65.8,63.7,36.0$, 34.8, 23.6, 21.5. HRMS (ESI) $m / z:[\mathrm{M}+\mathrm{Na}]^{+}$calcd for $\mathrm{C}_{22} \mathrm{H}_{22} \mathrm{~N}_{2} \mathrm{O}_{4} \mathrm{SNa}$ 433.1198; Found $\mathrm{m} / z$ 433.1187.

(2S,5R)-2-Isopropyl-5-propyl-1-tosyl-2,5-dihydro-1H-pyrrole (cis-2h)

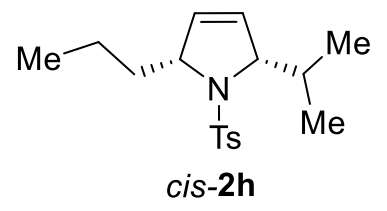


Following the general procedure B, $\mathbf{1 h}(0.2 \mathrm{mmol}, 62.0 \mathrm{mg}), 5 \mathrm{~mol} \%(S)-\mathbf{L} 1 \mathrm{AuCl}(9.2 \mathrm{mg}), 10$ $\operatorname{mol} \% \mathrm{NaBAr}_{4}{ }_{4}(17.6 \mathrm{mg})$ and $0.4 \mathrm{~mL}$ dry toluene were stirred at $110^{\circ} \mathrm{C}$ for $42 \mathrm{~h}$. The solvent was removed, and the residue was purified by flash column chromatography (hexane/EtOAc $=15: 1$ ) to afford cis-2h as a white solid (51.0 mg, 83\% yield, d.r. > 50/1). ${ }^{1} \mathbf{H}$ NMR (600 $\left.\mathbf{~ M H z , ~} \mathbf{C D C l}_{3}\right)$ $\delta 7.67(\mathrm{~d}, J=8.1 \mathrm{~Hz}, 2 \mathrm{H}), 7.27(\mathrm{~d}, J=8.1 \mathrm{~Hz}, 2 \mathrm{H}), 5.64-5.59(\mathrm{~m}, 1 \mathrm{H}), 5.52-5.48(\mathrm{~m}, 1 \mathrm{H}), 4.24$ $-4.19(\mathrm{~m}, 2 \mathrm{H}), 2.39$ (s, 3H), $2.12-2.02(\mathrm{~m}, 1 \mathrm{H}), 1.96-1.88(\mathrm{~m}, 1 \mathrm{H}), 1.56-1.46(\mathrm{~m}, 1 \mathrm{H}), 1.44$ $-1.34(\mathrm{~m}, 2 \mathrm{H}), 0.98(\mathrm{~d}, J=7.0 \mathrm{~Hz}, 3 \mathrm{H}), 0.94(\mathrm{t}, J=7.3 \mathrm{~Hz}, 3 \mathrm{H}), 0.86(\mathrm{~d}, J=6.8 \mathrm{~Hz}, 3 \mathrm{H}) .{ }^{13} \mathbf{C}$ NMR (151 MHz, CDCl3) $\delta 143.2,134.6,129.6,129.5,127.6,125.9,73.5,68.1,39.9,33.2,21.4$, 19.8, 19.4, 17.0, 14.0. HRMS (ESI) $\mathrm{m} / z:[\mathrm{M}+\mathrm{Na}]^{+}$calcd for $\mathrm{C}_{17} \mathrm{H}_{25} \mathrm{NO}_{2} \mathrm{SNa} 330.1504$; Found $\mathrm{m} / \mathrm{z}$ 330.1497.

\section{(2R,5S)-2,5-Diisopropyl-1-tosyl-2,5-dihydro-1H-pyrrole (cis-2i)}

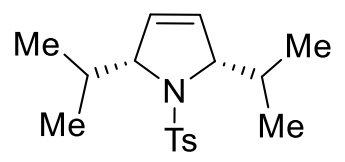

cis-2i

Following the general procedure B, $\mathbf{1 i}(0.2 \mathrm{mmol}, 62.2 \mathrm{mg}), 5 \mathrm{~mol} \%(S)-\mathbf{L} 1 \mathrm{AuCl}(9.2 \mathrm{mg}), 10$ mol\% $\mathrm{NaBAr}_{4}{ }_{4}(17.6 \mathrm{mg})$ and $0.4 \mathrm{~mL}$ dry toluene were stirred at $110{ }^{\circ} \mathrm{C}$ for $48 \mathrm{~h}$. The solvent was removed, and the residue was purified by flash column chromatography (hexane/EtOAc $=15: 1$ ) to afford cis-2i as a white solid (56.3 mg, 90\% yield, d.r. $>50 / 1) .{ }^{1} \mathbf{H}$ NMR (600 $\left.\mathbf{~ M H z , ~} \mathbf{C D C l}_{3}\right) \delta$ $7.65(\mathrm{~d}, J=8.3 \mathrm{~Hz}, 2 \mathrm{H}), 7.25(\mathrm{~d}, J=7.9 \mathrm{~Hz}, 2 \mathrm{H}), 5.60-5.58(\mathrm{~m}, 2 \mathrm{H}), 4.06-4.04(\mathrm{~m}, 1 \mathrm{H}), 4.04$ - 4.03 (m, 1H), 2.39 (s, 3H), 1.87 (oct, $J=6.9 \mathrm{~Hz}, 2 \mathrm{H}), 1.07$ (d, $J=7.0 \mathrm{~Hz}, 6 \mathrm{H}), 0.90$ (d, $J=6.8$ Hz, 6H). ${ }^{13} \mathbf{C}$ NMR (101 MHz, $\left.\mathbf{C D C l}_{3}\right) \delta$ 143.2, 134.4, 129.4, 128.0, 127.9, 74.0, 34.3, 21.5, 20.5, 18.4. HRMS (ESI) $m / z:[\mathrm{M}+\mathrm{Na}]^{+}$calcd for $\mathrm{C}_{17} \mathrm{H}_{25} \mathrm{NO}_{2} \mathrm{SNa} 330.1504$; Found $m / z 330.1511$.

\section{(2R,5S)-2-Cyclopropyl-5-isopropyl-1-tosyl-2,5-dihydro-1H-pyrrole (cis-2j)}

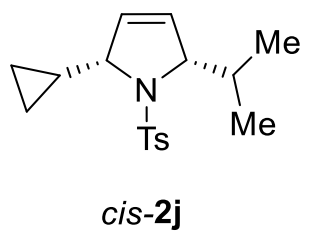

Following the general procedure B, $\mathbf{1 j}(0.2 \mathrm{mmol}, 61.1 \mathrm{mg}), 5 \mathrm{~mol} \%(\boldsymbol{S})-\mathbf{L} \mathbf{A u C l}(9.2 \mathrm{mg}), 10$ mol\% $\mathrm{NaBAr}_{4}{ }_{4}(17.6 \mathrm{mg})$ and $0.4 \mathrm{~mL}$ dry toluene were stirred at $110{ }^{\circ} \mathrm{C}$ for $24 \mathrm{~h}$. The solvent was 
removed, and the residue was purified by flash column chromatography (hexane/EtOAc $=15: 1$ ) to afford cis-2j as a white solid (56.3 mg, 91\% yield, d.r. > 50/1). ${ }^{\mathbf{1}} \mathbf{H}$ NMR (600 MHz, CDCl3) $\delta$ $7.66(\mathrm{~d}, J=8.3 \mathrm{~Hz}, 2 \mathrm{H}), 7.25(\mathrm{~d}, J=8.1 \mathrm{~Hz}, 2 \mathrm{H}), 5.54(\mathrm{dt}, J=6.4,1.9 \mathrm{~Hz}, 1 \mathrm{H}), 5.51(\mathrm{dt}, J=6.3$, $2.0 \mathrm{~Hz}, 1 \mathrm{H}), 4.29$ (dq, $J=5.4,1.9 \mathrm{~Hz}, 1 \mathrm{H}), 3.82(\mathrm{dq}, J=7.9,1.9 \mathrm{~Hz}, 1 \mathrm{H}), 2.39$ (s, 3H), $2.17-2.06$ $(\mathrm{m}, 1 \mathrm{H}), 1.08-1.00(\mathrm{~m}, 1 \mathrm{H}), 0.99(\mathrm{~d}, J=7.0 \mathrm{~Hz}, 3 \mathrm{H}), 0.89$ (d, $J=6.8 \mathrm{~Hz}, 3 \mathrm{H}), 0.65-0.58(\mathrm{~m}$, 1H), $0.60-0.53(\mathrm{~m}, 1 \mathrm{H}), 0.53-0.45(\mathrm{~m}, 1 \mathrm{H}), 0.29-0.20(\mathrm{~m}, 1 \mathrm{H}) .{ }^{13} \mathbf{C}$ NMR (101 MHz, CDCl 3$)$ $\delta 143.1,135.1,129.5,129.0,127.5,126.3,73.8,72.2,33.1,21.5,19.8,17.0,16.8,4.3,2.6$. HRMS (ESI) $m / z:[\mathrm{M}+\mathrm{Na}]^{+}$calcd for $\mathrm{C}_{17} \mathrm{H}_{23} \mathrm{NO}_{2} \mathrm{SNa} 328.1347$; Found $m / z$ 328.1337.

(2S,5S)-2-Isopropyl-5-phenyl-1-tosyl-2,5-dihydro-1H-pyrrole (cis-2l)

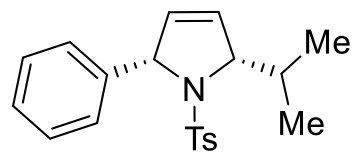

cis-2I

Following the general procedure B, 11 (0.2 mmol, $68.3 \mathrm{mg}), 5 \mathrm{~mol} \%$ (S)-L1AuCl (9.2 mg), 10 $\mathrm{mol} \% \mathrm{NaBAr}_{4}(17.6 \mathrm{mg})$ and $0.4 \mathrm{~mL}$ dry toluene were stirred at $110{ }^{\circ} \mathrm{C}$ for $24 \mathrm{~h}$. The solvent was removed, and the residue was purified by flash column chromatography (hexane/EtOAc $=10: 1$ ) to afford cis-2l as a yellow oil (50.6 mg, 75\% yield, d.r. > 50/1). ${ }^{1} \mathbf{H}$ NMR (600 MHz, CDCl3) $\delta$ $7.63(\mathrm{~d}, J=8.2 \mathrm{~Hz}, 2 \mathrm{H}), 7.44(\mathrm{~d}, J=8.6 \mathrm{~Hz}, 1 \mathrm{H}), 7.35-7.29(\mathrm{~m}, 2 \mathrm{H}), 7.29-7.22(\mathrm{~m}, 3 \mathrm{H}), 5.75$ - $5.69(\mathrm{~m}, 2 \mathrm{H}), 5.52-5.48(\mathrm{~m}, 1 \mathrm{H}), 4.42-4.37(\mathrm{~m}, 1 \mathrm{H}), 2.39(\mathrm{~s}, 3 \mathrm{H}), 2.13-2.03(\mathrm{~m}, 1 \mathrm{H}), 1.02$ $(\mathrm{d}, J=7.0 \mathrm{~Hz}, 3 \mathrm{H}), 0.83$ (d, $J=6.8 \mathrm{~Hz}, 3 \mathrm{H}) .{ }^{13} \mathbf{C}$ NMR (151 MHz, CDCl$) \delta 143.4,140.6,134.9$, 129.5, 129.3, 128.2, 127.7, 127.52, 127.51, 127.1, 73.9, 70.3, 33.0, 21.5, 20.2, 17.5. HRMS (ESI) $m / z:[\mathrm{M}+\mathrm{Na}]^{+}$calcd for $\mathrm{C}_{20} \mathrm{H}_{23} \mathrm{NO}_{2} \mathrm{SNa}$ 364.1347; Found $m / z$ 364.1334.

\section{(2S,5S)-2-Isopropyl-5-(4-methoxyphenyl)-1-tosyl-2,5-dihydro-1H-pyrrole (cis-2m)}

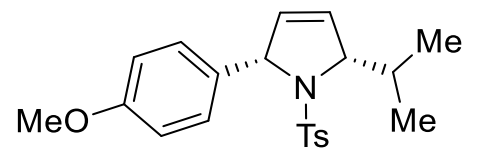

cis-2m

Following the general procedure B, $\mathbf{1 m}(0.2 \mathrm{mmol}, 74.8 \mathrm{mg}), 5 \mathrm{~mol} \%(\boldsymbol{S})-\mathbf{L 1 A u C l}(9.2 \mathrm{mg}), 10$ mol\% $\mathrm{NaBAr}_{4}(17.6 \mathrm{mg})$ and $0.4 \mathrm{~mL}$ dry toluene were stirred at $110{ }^{\circ} \mathrm{C}$ for $48 \mathrm{~h}$. The solvent was removed, and the residue was purified by flash column chromatography (hexane/EtOAc $=10: 1$ ) 
to afford cis-2m as a yellow solid (59.3 mg, 79\% yield, d.r. > 50/1). ${ }^{1} \mathbf{H}$ NMR (600 MHz, CDCl 3$)$ $\delta 7.63(\mathrm{~d}, J=8.2 \mathrm{~Hz}, 2 \mathrm{H}), 7.36(\mathrm{~d}, J=8.7 \mathrm{~Hz}, 2 \mathrm{H}), 7.25(\mathrm{~d}, J=8.1 \mathrm{~Hz}, 3 \mathrm{H}), 6.86(\mathrm{~d}, J=8.7 \mathrm{~Hz}$, $2 \mathrm{H}), 5.72(\mathrm{dt}, J=6.2,1.9 \mathrm{~Hz}, 1 \mathrm{H}), 5.69(\mathrm{dt}, J=6.3,1.9 \mathrm{~Hz}, 1 \mathrm{H}), 5.47(\mathrm{q}, J=2.2 \mathrm{~Hz}, 1 \mathrm{H}), 4.38$ $(\mathrm{dq}, J=4.3,2.0 \mathrm{~Hz}, 1 \mathrm{H}), 3.80(\mathrm{~s}, 3 \mathrm{H}), 2.40(\mathrm{~s}, 3 \mathrm{H}), 2.11-2.03(\mathrm{~m}, 1 \mathrm{H}), 1.01(\mathrm{~d}, J=7.0 \mathrm{~Hz}, 3 \mathrm{H})$, $0.82(\mathrm{~d}, J=6.8 \mathrm{~Hz}, 3 \mathrm{H}) .{ }^{13} \mathbf{C}$ NMR (151 MHz, CDCl3) $\delta$ 159.0, 143.2, 135.1, 132.8, 129.45, 129.39, 129.0, 127.7, 126.9, 113.6, 73.8, 69.8, 55.2, 32.9, 21.5, 20.1, 17.5. HRMS (ESI) $m / z$ : $[\mathrm{M}+\mathrm{Na}]^{+}$calcd for $\mathrm{C}_{21} \mathrm{H}_{25} \mathrm{NO}_{3} \mathrm{SNa}$ 394.1453; Found $m / z$ 394.1454.

(2S,5S)-2-Isopropyl-1-tosyl-5-(4-(trifluoromethyl)phenyl)-2,5-dihydro-1H-pyrrole (cis-2n)

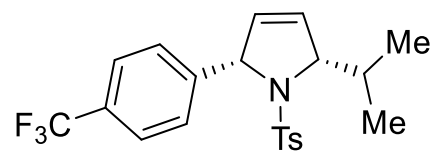

cis-2n

Following the general procedure B, 1 n $(0.2 \mathrm{mmol}, 81.9 \mathrm{mg}), 5 \mathrm{~mol} \%(S)-\mathrm{L} \mathbf{A u C l}(9.2 \mathrm{mg}), 10$ $\mathrm{mol} \% \mathrm{NaBAr}_{4}(17.6 \mathrm{mg})$ and $0.4 \mathrm{~mL}$ dry toluene were stirred at $110{ }^{\circ} \mathrm{C}$ for $48 \mathrm{~h}$. The solvent was removed, and the residue was purified by flash column chromatography (hexane/EtOAc $=10: 1$ ) to afford cis-2n as a yellow solid (60.2 mg, 74\% yield, d.r. > 50/1). ${ }^{1} \mathbf{H}$ NMR (600 MHz, CDCl3) $\delta 7.63(\mathrm{~d}, J=8.2 \mathrm{~Hz}, 2 \mathrm{H}), 7.60-7.52(\mathrm{~m}, 4 \mathrm{H}), 7.25(\mathrm{~d}, J=7.7 \mathrm{~Hz}, 3 \mathrm{H}), 5.74(\mathrm{dt}, J=6.3,2.0 \mathrm{~Hz}$, $1 \mathrm{H}), 5.71(\mathrm{dt}, J=6.3,2.1 \mathrm{~Hz}, 1 \mathrm{H}), 5.51(\mathrm{q}, J=2.2 \mathrm{~Hz}, 1 \mathrm{H}), 4.39(\mathrm{dq}, J=4.4,2.1 \mathrm{~Hz}, 1 \mathrm{H}), 2.39$ (s, 3H), $2.15-2.05(\mathrm{~m}, 1 \mathrm{H}), 1.02(\mathrm{~d}, J=7.0 \mathrm{~Hz}, 3 \mathrm{H}), 0.82(\mathrm{~d}, J=6.8 \mathrm{~Hz}, 3 \mathrm{H}) .{ }^{13} \mathrm{C}$ NMR $(\mathbf{1 0 1}$ MHz, CDCl 3$) \delta 144.6(\mathrm{q}, J=1.5 \mathrm{~Hz}), 143.8,134.3,129.7(\mathrm{q}, J=32.3 \mathrm{~Hz}), 129.6,128.5,127.85$, 127.77, 127.72, 125.2 (q, $J=3.8 \mathrm{~Hz}), 124.1$ (q, $J=272.0 \mathrm{~Hz}), 74.0,69.8,33.0,21.5$, 20.2, 17.5. ${ }^{19}$ F NMR (376 MHz, CDCl $) \delta-61.83$. HRMS (ESI) $m / z:[\mathrm{M}+\mathrm{Na}]^{+}$calcd for $\mathrm{C}_{21} \mathrm{H}_{22} \mathrm{~F}_{3} \mathrm{NO}_{2} \mathrm{SNa}$ 432.1221; Found $\mathrm{m} / \mathrm{z} 432.1208$.

(2S,5S)-2-(furan-2-yl)-5-Isopropyl-1-tosyl-2,5-dihydro-1H-pyrrole (cis-2o)

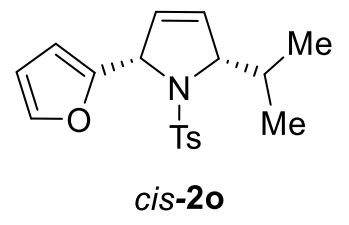

Following the general procedure B, $10(0.2 \mathrm{mmol}, 66.2 \mathrm{mg}), 5 \mathrm{~mol} \%(\boldsymbol{S})$-L1AuCl $(9.2 \mathrm{mg}), 10$ mol\% $\mathrm{NaBAr}_{4}(17.6 \mathrm{mg})$ and $0.4 \mathrm{~mL}$ dry toluene were stirred at $110{ }^{\circ} \mathrm{C}$ for $38 \mathrm{~h}$. The solvent was 
removed, and the residue was purified by flash column chromatography (hexane/EtOAc $=10: 1$ ) to afford cis-2o as an orange oil (29.3 mg, 44\% yield, d.r. = 96/4). ${ }^{\mathbf{1}} \mathbf{H}$ NMR (600 $\left.\mathbf{~ M H z , ~ C D C l} 3\right)$ $\delta 7.64(\mathrm{~d}, J=8.3 \mathrm{~Hz}, 2 \mathrm{H}), 7.33(\mathrm{dd}, J=1.8,0.9 \mathrm{~Hz}, 1 \mathrm{H}), 7.28-7.23(\mathrm{~m}, 2 \mathrm{H}), 6.36-6.25(\mathrm{~m}, 2 \mathrm{H})$, $5.75(\mathrm{dt}, J=6.3,2.1 \mathrm{~Hz}, 1 \mathrm{H}), 5.69(\mathrm{dt}, J=6.3,2.1 \mathrm{~Hz}, 1 \mathrm{H}), 5.54(\mathrm{q}, J=2.2 \mathrm{~Hz}, 1 \mathrm{H}), 4.44(\mathrm{dq}, J$ $=4.4,2.1 \mathrm{~Hz}, 1 \mathrm{H}), 2.40(\mathrm{~s}, 3 \mathrm{H}), 2.16-2.05(\mathrm{~m}, 1 \mathrm{H}), 0.99(\mathrm{~d}, J=7.0 \mathrm{~Hz}, 3 \mathrm{H}), 0.81$ (d, $J=6.8 \mathrm{~Hz}$, 3H). ${ }^{13}$ C NMR (101 MHz, CDCl $) \delta 153.2,143.4,142.1,135.3,129.5,127.9,127.6,126.6,110.4$, 108.2, 73.6, 64.1, 32.8, 21.5, 19.9, 16.8. HRMS (ESI) $m / z:[\mathrm{M}+\mathrm{Na}]^{+}$calcd for $\mathrm{C}_{18} \mathrm{H}_{21} \mathrm{NO}_{3} \mathrm{SNa}$ 354.1140; Found $m / z$ 354.1145.

(2S,5S)-2-Isopropyl-5-(thiophen-2-yl)-1-tosyl-2,5-dihydro-1H-pyrrole (cis-2p)

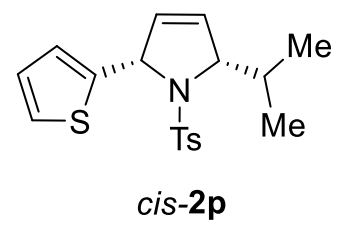

Following the general procedure B, 1 p (0.2 mmol, $69.3 \mathrm{mg}), 5 \mathrm{~mol} \%(\boldsymbol{S})-\mathbf{L 1 A u C l}(9.2 \mathrm{mg}), 10$ $\mathrm{mol} \% \mathrm{NaBAr}_{4}(17.6 \mathrm{mg})$ and $0.4 \mathrm{~mL}$ dry toluene were stirred at $110{ }^{\circ} \mathrm{C}$ for $44 \mathrm{~h}$. The solvent was removed, and the residue was purified by flash column chromatography (hexane/EtOAc $=10: 1$ ) to afford cis-2p as an orange oil (35.0 mg, 50\% yield, d.r. > 50/1). ${ }^{1} \mathbf{H}$ NMR (600 MHz, CDCl3) $\delta 7.64(\mathrm{~d}, J=8.3 \mathrm{~Hz}, 2 \mathrm{H}), 7.27-7.22(\mathrm{~m}, 3 \mathrm{H}), 7.07(\mathrm{dt}, J=3.5,1.0 \mathrm{~Hz}, 1 \mathrm{H}), 6.95(\mathrm{dd}, J=5.1$, $3.5 \mathrm{~Hz}, 1 \mathrm{H}), 5.84-5.70(\mathrm{~m}, 3 \mathrm{H}), 4.45-4.36(\mathrm{~m}, 1 \mathrm{H}), 2.40(\mathrm{~s}, 3 \mathrm{H}), 2.09-2.02(\mathrm{~m}, 1 \mathrm{H}), 1.00(\mathrm{~d}$, $J=7.0 \mathrm{~Hz}, 3 \mathrm{H}), 0.80(\mathrm{~d}, J=6.8 \mathrm{~Hz}, 3 \mathrm{H}) .{ }^{13} \mathbf{C}$ NMR (101 MHz, CDCl $\left.\mathbf{3}\right) \delta 144.7,143.4,135.2$, 129.5, 128.6, 127.65, 127.61, 126.4, 126.2, 125.5, 73.8, 65.8, 32.8, 21.5, 19.9, 17.3. HRMS (ESI) $m / z:[\mathrm{M}+\mathrm{Na}]^{+}$calcd for $\mathrm{C}_{18} \mathrm{H}_{21} \mathrm{NO}_{2} \mathrm{~S}_{2} \mathrm{Na} 370.0912$, found $m / z, 370.0917$.

\section{3-((2S,5S)-5-Isopropyl-1-tosyl-2,5-dihydro-1H-pyrrol-2-yl)-1-tosyl-1H-indole (cis-2q)}

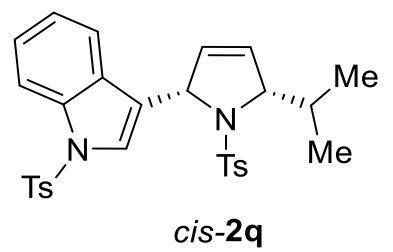

Following the general procedure B, 1q (0.2 mmol, $106.9 \mathrm{mg}), 5 \mathrm{~mol} \%(\boldsymbol{S})-\mathbf{L 1 A u C l}(9.2 \mathrm{mg}), 10$ $\mathrm{mol} \% \mathrm{NaBAr}_{4}(17.6 \mathrm{mg})$ and $0.4 \mathrm{~mL}$ dry toluene were stirred at $110{ }^{\circ} \mathrm{C}$ for $48 \mathrm{~h}$. The solvent was 
removed, and the residue was purified by flash column chromatography (hexane/EtOAc $=6: 1$ ) to afford cis-2q as a yellow solid (99.5 mg, 93\% yield, d.r. > 50/1). $\left.{ }^{1} \mathbf{H} \mathbf{~ N M R ~ ( 6 0 0 ~} \mathbf{M H z}, \mathbf{C D C l}_{3}\right) \delta$ $7.97(\mathrm{~d}, J=8.3 \mathrm{~Hz}, 1 \mathrm{H}), 7.77-7.73(\mathrm{~m}, 3 \mathrm{H}), 7.68(\mathrm{~d}, J=8.3 \mathrm{~Hz}, 2 \mathrm{H}), 7.58(\mathrm{~s}, 1 \mathrm{H}), 7.32-7.29$ (m, 1H), $7.25-7.21(\mathrm{~m}, 3 \mathrm{H}), 7.19(\mathrm{~d}, J=8.2 \mathrm{~Hz}, 2 \mathrm{H}), 5.85(\mathrm{dt}, J=6.2,2.1 \mathrm{~Hz}, 1 \mathrm{H}), 5.74(\mathrm{dt}, J=$ 6.2, $2.1 \mathrm{~Hz}, 1 \mathrm{H}), 5.68-5.63(\mathrm{~m}, 1 \mathrm{H}), 4.37(\mathrm{dq}, J=5.9,2.0 \mathrm{~Hz}, 1 \mathrm{H}), 2.39(\mathrm{~s}, 3 \mathrm{H}), 2.31(\mathrm{~s}, 3 \mathrm{H})$, $2.10-2.02(\mathrm{~m}, 1 \mathrm{H}), 1.01(\mathrm{~d}, J=7.0 \mathrm{~Hz}, 3 \mathrm{H}), 0.87(\mathrm{~d}, J=6.8 \mathrm{~Hz}, 3 \mathrm{H}) .{ }^{13} \mathbf{C}$ NMR $(\mathbf{1 0 1} \mathbf{M H z}$, CDCl3) $\delta 144.8,143.6,135.2,135.0,134.2,129.8,129.6,128.9,127.84,127.78,127.73,126.8$, 125.1, 124.6, 123.2, 123.0, 120.1, 113.6, 73.8, 63.4, 33.4, 21.5, 21.5, 20.2, 17.8. HRMS (ESI) m/z: $[\mathrm{M}+\mathrm{Na}]^{+}$calcd for $\mathrm{C}_{29} \mathrm{H}_{30} \mathrm{~N}_{2} \mathrm{O}_{4} \mathrm{~S}_{2} \mathrm{Na}$ 557.1545; Found $\mathrm{m} / z$ 557.1545.

(2S,5R)-2-Isopropyl-5-((E)-styryl)-1-tosyl-2,5-dihydro-1H-pyrrole (cis-2r)

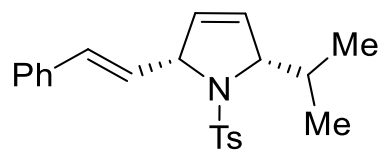

cis-2r

Following the general procedure B, $\mathbf{1 r}(0.2 \mathrm{mmol}, 73.5 \mathrm{mg}), 5 \mathrm{~mol} \%(\boldsymbol{S})$-L1AuCl $(9.2 \mathrm{mg}), 10$ $\mathrm{mol} \% \mathrm{NaBAr}_{4}(17.6 \mathrm{mg})$ and $0.4 \mathrm{~mL}$ dry toluene were stirred at $110{ }^{\circ} \mathrm{C}$ for $72 \mathrm{~h}$. The solvent was removed, and the residue was purified by flash column chromatography (hexane/EtOAc $=10: 1$ ) to afford cis-2r as a yellow solid (39.2 mg, 53\% yield, d.r. > 50/1). ${ }^{1} \mathbf{H}$ NMR (600 MHz, CDCl3) $\delta 7.74(\mathrm{~d}, J=8.2 \mathrm{~Hz}, 2 \mathrm{H}), 7.39-7.21(\mathrm{~m}, 7 \mathrm{H}), 6.52(\mathrm{dd}, J=16.0,1.0 \mathrm{~Hz}, 1 \mathrm{H}), 6.11(\mathrm{dd}, J=15.9$, $7.1 \mathrm{~Hz}, 1 \mathrm{H}), 5.68-5.61(\mathrm{~m}, 2 \mathrm{H}), 5.09-5.01(\mathrm{~m}, 1 \mathrm{H}), 4.45(\mathrm{dq}, J=4.0,1.7 \mathrm{~Hz}, 1 \mathrm{H}), 2.39(\mathrm{~s}, 3 \mathrm{H})$, $2.24-2.14(\mathrm{~m}, 1 \mathrm{H}), 1.01(\mathrm{~d}, J=7.0 \mathrm{~Hz}, 3 \mathrm{H}), 0.85(\mathrm{~d}, J=6.8 \mathrm{~Hz}, 3 \mathrm{H}) .{ }^{13} \mathrm{C}$ NMR (101 MHz, CDCl$\left._{3}\right) \delta 143.4,136.5,135.4,131.6,129.6,129.2,128.7,128.4,127.71,127.67,126.7,126.6$, 73.4, 69.1, 32.6, 21.5, 19.7, 16.8. HRMS (ESI) $m / z:[\mathrm{M}+\mathrm{Na}]^{+}$calcd for $\mathrm{C}_{22} \mathrm{H}_{25} \mathrm{NO}_{2} \mathrm{SNa} 390.1504$; Found $m / z 390.1503$.

(2R,5R)-2-Methyl-5-propyl-1-tosyl-2,5-dihydro-1H-pyrrole (trans-2a)

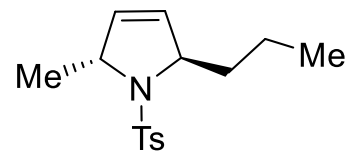

trans-2a 
Following the general procedure B, $\mathbf{1 a}(0.15 \mathrm{mmol}, 41.9 \mathrm{mg}), 5 \mathrm{~mol} \%(\boldsymbol{R})-\mathbf{L} 1 \mathrm{AuCl}(6.6 \mathrm{mg}), 10$ $\mathrm{mol} \% \mathrm{NaBAr}_{4}(13.2 \mathrm{mg})$ and $0.75 \mathrm{~mL}$ dry toluene were stirred at $110{ }^{\circ} \mathrm{C}$ for $72 \mathrm{~h}$. The solvent was removed, and the residue was purified by flash column chromatography (hexane/EtOAc $=$ 10:1) to afford trans-2a as a white solid (38.3 mg, 91\% yield, d.r. $=92 / 8) .{ }^{1} \mathbf{H}$ NMR (600 MHz, CDCl3) $\delta 7.75-7.71(\mathrm{~m}, 2 \mathrm{H}), 7.29-7.23(\mathrm{~m}, 2 \mathrm{H}), 5.62-5.55(\mathrm{~m}, 2 \mathrm{H}), 4.64-4.58(\mathrm{~m}, 2 \mathrm{H}), 2.40$ (s, 3H), $1.94-1.81(\mathrm{~m}, 1 \mathrm{H}), 1.78-1.69(\mathrm{~m}, 1 \mathrm{H}), 1.33(\mathrm{~d}, J=6.1 \mathrm{~Hz}, 3 \mathrm{H}), 1.25-1.14(\mathrm{~m}, 2 \mathrm{H})$, $0.84(\mathrm{t}, J=7.4 \mathrm{~Hz}, 3 \mathrm{H}) .{ }^{\mathbf{1 3}} \mathbf{C}$ NMR (151 MHz, CDCl $\left.\mathbf{3}\right) \delta 142.6,139.6,131.0,129.3,128.1,126.8$, $67.3,63.5,36.5,21.4,21.1,17.5,14.0$.

(2R,5R)-2-Benzyl-5-methyl-1-tosyl-2,5-dihydro-1H-pyrrole (trans-2b)

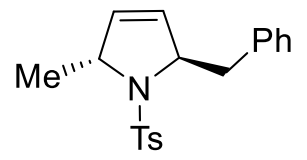

trans-2b

Following the general procedure B, $\mathbf{1 b}(0.15 \mathrm{mmol}, 49.1 \mathrm{mg}), 5 \mathrm{~mol} \%(\boldsymbol{R})-\mathbf{L 1 A u C l}(6.6 \mathrm{mg}), 10$ mol\% $\mathrm{NaBAr}_{4}{ }_{4}(13.2 \mathrm{mg})$ and $0.75 \mathrm{~mL}$ dry toluene were stirred at $110{ }^{\circ} \mathrm{C}$. After $24 \mathrm{~h}, 5 \mathrm{~mol} \%$ $(\boldsymbol{R})-\mathrm{L} 1 \mathrm{AuCl}(6.6 \mathrm{mg})$ and $10 \mathrm{~mol} \% \mathrm{NaBAr}_{4}(13.2 \mathrm{mg})$ were added to the reaction mixture and the reaction was continued for $48 \mathrm{~h}$. After completion, the solvent was removed, and the residue was purified by flash column chromatography (hexane/EtOAc $=15: 1$ ) to afford trans-2b as a colorless oil $(43.6 \mathrm{mg}, 89 \%$ yield, d.r. $=84 / 16) .{ }^{1} \mathbf{H}$ NMR $\left(600 \mathrm{MHz}, \mathbf{C D C l}_{3}\right) \delta 7.84-7.78(\mathrm{~m}$, 2H), $7.34-7.24(\mathrm{~m}, 4 \mathrm{H}), 7.24-7.13(\mathrm{~m}, 3 \mathrm{H}), 5.55-5.46(\mathrm{~m}, 2 \mathrm{H}), 4.79$ (dddt, $J=8.9,5.3,3.5$, $1.6 \mathrm{~Hz}, 1 \mathrm{H}), 4.60-4.46(\mathrm{~m}, 1 \mathrm{H}), 3.57$ (dd, $J=12.8,3.7 \mathrm{~Hz}, 1 \mathrm{H}), 2.76$ (dd, $J=12.8,9.3 \mathrm{~Hz}, 1 \mathrm{H}$ ), $2.42(\mathrm{~s}, 3 \mathrm{H}), 1.30(\mathrm{~d}, J=6.4 \mathrm{~Hz}, 3 \mathrm{H}) .{ }^{13} \mathbf{C}$ NMR (126 MHz, CDCl $) \delta 142.8,139.8,137.6,131.3$, $129.8,129.5,128.2,127.8,126.8,126.4,68.6,63.6,42.0,21.4,20.8$.

(2R,5R)-2-Isopropyl-5-methyl-1-tosyl-2,5-dihydro-1H-pyrrole (trans-2c)

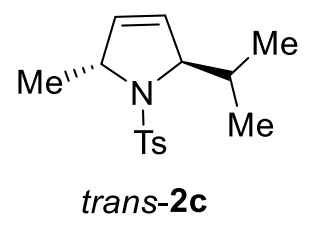

Following the general procedure B, 1c $(0.15 \mathrm{mmol}, 41.9 \mathrm{mg}), 5 \mathrm{~mol} \%(\boldsymbol{R})-\mathbf{L 1 A u C l}(6.6 \mathrm{mg}), 10$ mol\% $\mathrm{NaBAr}_{4} \mathrm{~F}_{4}(13.2 \mathrm{mg})$ and $0.75 \mathrm{~mL}$ dry toluene were stirred at $110{ }^{\circ} \mathrm{C}$. After $24 \mathrm{~h}, 5 \mathrm{~mol} \%$ 
(R)-L1AuCl (6.6 mg) and $10 \mathrm{~mol}^{2} \mathrm{NaBAr}_{4}{ }_{4}(13.2 \mathrm{mg})$ were added to the reaction mixture and the reaction was continued for $48 \mathrm{~h}$. After completion, the solvent was removed, and the residue was purified by flash column chromatography (hexane/EtOAc $=20: 1$ to hexane/EtOAc $=15 / 1$ ) to afford trans-2c as a colorless oil (31.1 mg, 74\% yield, d.r. = 85/15). ${ }^{\mathbf{1}} \mathbf{H}$ NMR (500 MHz, CDCl 3$)$ $\delta 7.72-7.59(\mathrm{~m}, 2 \mathrm{H}), 7.26-7.15(\mathrm{~m}, 2 \mathrm{H}), 5.60(\mathrm{dt}, J=6.5,1.8 \mathrm{~Hz}, 1 \mathrm{H}), 5.51(\mathrm{dt}, J=6.5,1.9 \mathrm{~Hz}$, $1 \mathrm{H}), 4.60-4.53(\mathrm{~m}, 1 \mathrm{H}), 4.47(\mathrm{ddt}, J=5.6,3.7,1.9 \mathrm{~Hz}, 1 \mathrm{H}), 2.65-2.53(\mathrm{~m}, 1 \mathrm{H}), 2.34(\mathrm{~s}, 3 \mathrm{H})$, $1.27(\mathrm{~d}, J=6.4 \mathrm{~Hz}, 3 \mathrm{H}), 0.83(\mathrm{~d}, J=7.1 \mathrm{~Hz}, 3 \mathrm{H}), 0.56(\mathrm{~d}, J=6.7 \mathrm{~Hz}, 3 \mathrm{H}) .{ }^{13} \mathbf{C}$ NMR (126 MHz, $\left.\mathbf{C D C l}_{3}\right) \delta 142.5,139.6,132.7,129.3,126.7,124.2,72.9,64.00,30.7,21.4,21.00,19.4,15.1$.

(2R,5R)-2-Cyclohexyl-5-methyl-1-tosyl-2,5-dihydro-1H-pyrrole (trans-2d)

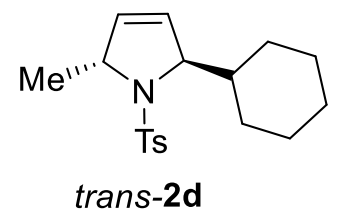

Following the general procedure B, $1 d(0.15 \mathrm{mmol}, 47.9 \mathrm{mg}), 5 \mathrm{~mol} \%(\boldsymbol{R})-\mathbf{L 1 A u C l}(6.6 \mathrm{mg}), 10$ $\operatorname{mol} \% \mathrm{NaBAr}_{4}{ }_{4}(13.2 \mathrm{mg})$ and $0.75 \mathrm{~mL}$ dry toluene were stirred at $110{ }^{\circ} \mathrm{C}$. After $24 \mathrm{~h}, 5 \mathrm{~mol} \%$ (R)-L1AuCl (6.6 mg) and $10 \mathrm{~mol} \% \mathrm{NaBAr}_{4}(13.2 \mathrm{mg})$ were added to the reaction mixture and the reaction was continued for $48 \mathrm{~h}$. After completion, the solvent was removed, and the residue was purified by flash column chromatography (hexane/EtOAc $=20: 1$ to hexane/EtOAc $=15 / 1$ ) to afford trans-2d as a colorless oil (39.0 mg, 81\% yield, d.r. = 85/15). ${ }^{\mathbf{1}} \mathbf{H} \mathbf{~ N M R}(\mathbf{6 0 0} \mathbf{M H z}, \mathbf{C D C l})$ $\delta 7.73(\mathrm{~d}, J=8.3 \mathrm{~Hz}, 2 \mathrm{H}), 7.26(\mathrm{~d}, J=8.0 \mathrm{~Hz}, 2 \mathrm{H}), 5.60(\mathrm{tdd}, J=8.2,6.4,1.6 \mathrm{~Hz}, 2 \mathrm{H}), 4.60-$ $4.48(\mathrm{~m}, 2 \mathrm{H}), 2.40(\mathrm{~s}, 3 \mathrm{H}), 2.30-2.19(\mathrm{~m}, 1 \mathrm{H}), 1.85-1.70(\mathrm{~m}, 2 \mathrm{H}), 1.57-1.50(\mathrm{~m}, 1 \mathrm{H}), 1.36(\mathrm{~d}$, $J=6.3 \mathrm{~Hz}, 3 \mathrm{H}), 1.32-1.22(\mathrm{~m}, 3 \mathrm{H}), 1.06-0.95(\mathrm{~m}, 2 \mathrm{H}), 0.91(\mathrm{qd}, J=12.6,3.6 \mathrm{~Hz}, 1 \mathrm{H}), 0.71$ (qd, $J=12.4,3.6 \mathrm{~Hz}, 1 \mathrm{H}) .{ }^{13} \mathbf{C}$ NMR (126 MHz, CDCl3) $\delta 142.5,139.7,132.1,129.3,126.7$, $125.3,72.6,63.7,40.8,30.2,26.62,26.58,26.1,25.6,21.4,21.2$.

(2R,5R)-2-(2-chloroethyl)-5-Methyl-1-tosyl-2,5-dihydro-1H-pyrrole (trans-2e)

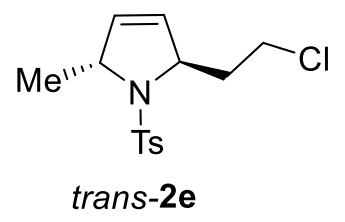


Following the general procedure B, $1 \mathbf{e}(0.15 \mathrm{mmol}, 45.0 \mathrm{mg}), 10 \mathrm{~mol} \%(\boldsymbol{R})-\mathbf{L} \mathbf{A u C l}(13.2 \mathrm{mg})$, $20 \mathrm{~mol} \% \mathrm{NaBAr}_{4}{ }_{4}(26.4 \mathrm{mg})$ and $0.75 \mathrm{~mL}$ dry toluene were stirred at $110{ }^{\circ} \mathrm{C}$ for $72 \mathrm{~h}$. The solvent was removed, and the residue was purified by flash column chromatography (hexane/EtOAc $=$ 10:1) to afford trans-2e as a colorless oil (29.5 $\mathrm{mg}$, 66\% yield, $77 \%$ yield based on recovery, $d . r$. $=86 / 14)$ and recovered $1 \mathbf{e}(6.9 \mathrm{mg}) .{ }^{1} \mathbf{H}$ NMR $(\mathbf{6 0 0} \mathbf{M H z}, \mathbf{C D C l} 3) \delta 7.74(\mathrm{~d}, J=8.3 \mathrm{~Hz}, 2 \mathrm{H}), 7.29$ $(\mathrm{d}, J=7.9 \mathrm{~Hz}, 2 \mathrm{H}), 5.70-5.62(\mathrm{~m}, 2 \mathrm{H}), 4.74-4.61(\mathrm{~m}, 2 \mathrm{H}), 3.52(\mathrm{ddd}, J=10.9,7.9,5.7 \mathrm{~Hz}, 1 \mathrm{H})$, $3.43(\mathrm{dt}, J=10.9,7.6 \mathrm{~Hz}, 1 \mathrm{H}), 2.41(\mathrm{~s}, 3 \mathrm{H}), 2.45-2.33(\mathrm{~m}, 2 \mathrm{H}), 1.32(\mathrm{~d}, J=6.2 \mathrm{~Hz}, 3 \mathrm{H}) .{ }^{13} \mathrm{C}$ NMR (126 MHz, CDCl3) $\delta 143.0,138.8,132.0,129.5,127.0,126.8,65.1,63.7,40.5,37.2,21.4$, 20.6 .

\section{(R)-2-Propyl-1-tosyl-1-azaspiro[4.5]dec-3-ene (2s)}

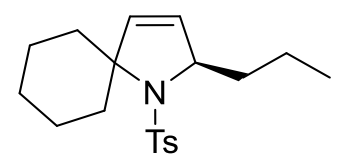

2s

Following the general procedure B, $1 \mathrm{~s}(0.15 \mathrm{mmol}, 50.0 \mathrm{mg}), 5 \mathrm{~mol} \%(\boldsymbol{R})-\mathbf{L} 2 \mathrm{AuCl}(6.6 \mathrm{mg}), 10$ mol\% $\mathrm{NaBAr}_{4}{ }_{4}(13.2 \mathrm{mg})$ and $0.3 \mathrm{~mL}$ dry $\mathrm{PhCF}_{3}$ were stirred at $95{ }^{\circ} \mathrm{C}$ for $48 \mathrm{~h}$. The solvent was removed, and the residue was purified by flash column chromatography (hexane/EtOAc $=10: 1$ ) to afford $2 \mathrm{~s}$ as a colorless oil $(40.8 \mathrm{mg}, 82 \%$ yield, e.r. $=97 / 3) .{ }^{1} \mathbf{H} \mathbf{~ N M R ~}\left(\mathbf{5 0 0} \mathbf{~ M H z}, \mathbf{C D C l}_{3}\right) \delta$ $7.74(\mathrm{~d}, J=8.3 \mathrm{~Hz}, 2 \mathrm{H}), 7.25(\mathrm{~d}, J=8.0 \mathrm{~Hz}, 2 \mathrm{H}), 6.12(\mathrm{dd}, J=6.6,1.7 \mathrm{~Hz}, 1 \mathrm{H}), 5.66(\mathrm{dd}, J=6.6$, $2.1 \mathrm{~Hz}, 1 \mathrm{H}), 4.53-4.46(\mathrm{~m}, 1 \mathrm{H}), 2.53(\mathrm{td}, J=13.1,4.7 \mathrm{~Hz}, 1 \mathrm{H}), 2.40$ (s, 3H), 2.34 (td, $J=13.1$, $4.2 \mathrm{~Hz}, 1 \mathrm{H}), 2.05-1.95(\mathrm{~m}, 1 \mathrm{H}), 1.87-1.79(\mathrm{~m}, 1 \mathrm{H}), 1.77-1.59(\mathrm{~m}, 4 \mathrm{H}), 1.46-1.19(\mathrm{~m}, 6 \mathrm{H})$, $0.91(\mathrm{t}, J=7.3 \mathrm{~Hz}, 3 \mathrm{H}) .{ }^{13} \mathbf{C} \mathbf{N M R}\left(\mathbf{1 2 6} \mathbf{~ M H z}, \mathbf{C D C l}_{3}\right) \delta 142.3,140.09,140.08,131.7,129.2$, 127.2, 127.0, 76.2, 67.7, 40.0, 39.1, 35.4, 25.2, 24.6, 24.5, 21.4, 18.2, 14.0. HRMS (ESI) $\mathrm{m} / \mathrm{z}$ : $[\mathrm{M}+\mathrm{Na}]^{+}$calcd for $\mathrm{C}_{19} \mathrm{H}_{27} \mathrm{NO}_{2} \mathrm{SNa}$ 372.1973; Found $\mathrm{m} / \mathrm{z}$ 372.1983 e.r. $=$ 97/3; HPLC(IC, Hexane $/ \mathrm{PrOH}=90 / 10$, flow rate $=1.0 \mathrm{~mL} / \mathrm{min}, \lambda=200 \mathrm{~nm}) \mathrm{t}_{\mathrm{R}}=13.94$ min $($ major $), \mathrm{t}_{\mathrm{R}}=23.88$ $\min$ (minor).

\section{(S)-2-Nonyl-1-tosyl-2,5-dihydro-1H-pyrrole (2u)}

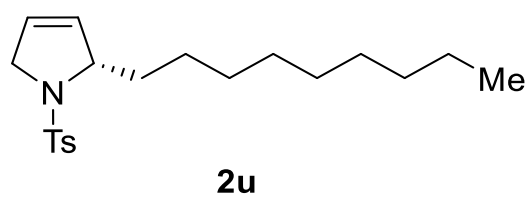


Following the general procedure B, $\mathbf{1 u}(0.15 \mathrm{mmol}, 52.5 \mathrm{mg}), 10 \mathrm{~mol} \%(\boldsymbol{S})-\mathbf{L} 1 \mathrm{AuCl}(9.2 \mathrm{mg}), 20$ mol\% $\mathrm{NaBAr}_{4}{ }_{4}(26.4 \mathrm{mg})$ and $0.3 \mathrm{~mL}$ dry $\mathrm{PhCF}_{3}$ were stirred at $95{ }^{\circ} \mathrm{C}$ for $72 \mathrm{~h}$. The solvent was removed, and the residue was purified by flash column chromatography (hexane/EtOAc $=10: 1$ ) to afford $\mathbf{2 u}$ as a yellow oil (20.0 $\mathrm{mg}, 38 \%$ yield, $83 \%$ yield based on conversion) and recover starting material 1u (28.3 mg). ${ }^{1} \mathbf{H}$ NMR $\left(400 \mathrm{MHz}, \mathbf{C D C l}_{3}\right) \delta 7.70(\mathrm{~d}, J=8.3 \mathrm{~Hz}, 2 \mathrm{H}), 7.29(\mathrm{~d}, J$ $=8.0 \mathrm{~Hz}, 2 \mathrm{H}), 5.62-5.53(\mathrm{~m}, 2 \mathrm{H}), 4.51-4.41(\mathrm{~m}, 1 \mathrm{H}), 4.16-4.05(\mathrm{~m}, 2 \mathrm{H}), 2.41(\mathrm{~s}, 3 \mathrm{H}), 1.82-$ $1.68(\mathrm{~m}, 2 \mathrm{H}), 1.34-1.18(\mathrm{~m}, 15 \mathrm{H}), 0.88(\mathrm{t}, J=6.8 \mathrm{~Hz}, 3 \mathrm{H}) .{ }^{13} \mathbf{C} \mathbf{N M R}\left(\mathbf{1 0 1} \mathbf{~ M H z}, \mathbf{C D C l}_{3}\right) \delta 143.2$, 134.9, 129.8, 129.6, 127.4, 124.5, 67.4, 55.6, 36.1, 31.9, 29.62, 29.57, 29.3, 24.5, 22.7, 21.5, 14.1 . HRMS (ESI) $\mathrm{m} / \mathrm{z}:[\mathrm{M}+\mathrm{Na}]^{+}$calcd for $\mathrm{C}_{20} \mathrm{H}_{31} \mathrm{NO}_{2} \mathrm{SNa} 372.1973$; Found $\mathrm{m} / \mathrm{z}$ 372.1983. e.r. = 94/6; HPLC (IC, Hexane $/ \mathrm{iPrOH}=95 / 5$, flow rate $=1.0 \mathrm{~mL} / \mathrm{min}, \lambda=200 \mathrm{~nm}$ ) $\mathrm{t}_{\mathrm{R}}=33.03 \mathrm{~min}$ (major), $\mathrm{t}_{\mathrm{R}}$ $=31.54 \mathrm{~min}$ (minor).

(R)-2-Cyclopropyl-1-tosyl-2,5-dihydro-1H-pyrrole (2v)

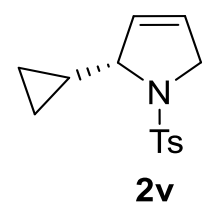

Following the general procedure B, $\mathbf{1 v}(0.2 \mathrm{mmol}, 52.7 \mathrm{mg}), 5 \mathrm{~mol} \% \mathbf{L 3 A u C l}(7.6 \mathrm{mg}), 10 \mathrm{~mol} \%$ $\mathrm{NaBAr}_{4} \mathrm{~F}_{4}(17.6 \mathrm{mg})$ and $0.4 \mathrm{~mL}$ dry toluene were stirred at $110{ }^{\circ} \mathrm{C}$ for $24 \mathrm{~h}$. The solvent was removed, and the residue was purified by flash column chromatography (hexane/EtOAc $=10: 1$ ) to afford $\mathbf{2 v}$ as a white solid (42.2mg, 80\% yield, 90\% ee). $\left.{ }^{1} \mathbf{H} \mathbf{~ N M R ~ ( 6 0 0 ~} \mathbf{M H z}, \mathbf{C D C l}_{3}\right) \delta 7.68$ $(\mathrm{d}, J=8.3 \mathrm{~Hz}, 2 \mathrm{H}), 7.25(\mathrm{~d}, J=7.9 \mathrm{~Hz}, 2 \mathrm{H}), 5.61(\mathrm{dq}, J=6.2,1.8 \mathrm{~Hz}, 1 \mathrm{H}), 5.51(\mathrm{dq}, J=6.3,2.0$ $\mathrm{Hz}, 1 \mathrm{H}), 4.17-4.08$ (m, 3H), 2.38 (s, 3H), $1.06-0.98$ (m, 1H), $0.52-0.47$ (m, 2H), $0.47-0.41$ (m, 1H), $0.31-0.24(\mathrm{~m}, 1 \mathrm{H}) .{ }^{13} \mathbf{C}$ NMR (101 MHz, CDCl $) \delta 143.2,135.5,129.5,128.9,127.3$, 125.2, 70.4, 55.6, 21.4, 16.3, 4.0, 1.6. These data are consistent with the literature ${ }^{10} . \mathbf{9 0 \%} \boldsymbol{e} \boldsymbol{e}$; HPLC(IC, Hexane $/ \mathrm{PrOH}=90 / 10$, flow rate $=1.0 \mathrm{~mL} / \mathrm{min}, \lambda=206 \mathrm{~nm}$ ) $\mathrm{t}_{\mathrm{R}}=41.34 \mathrm{~min}$ (major), $\mathrm{t}_{\mathrm{R}}=53.00 \mathrm{~min}$ (minor).

(2R,5S)-2-Heptyl-5-(2-iodobenzyl)-1-tosyl-2,5-dihydro-1H-pyrrole (cis-2w) 


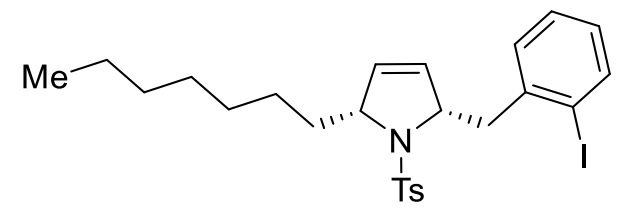

cis-2w

Following the general procedure B, $1 \mathbf{w}(0.2 \mathrm{mmol}, 107.4 \mathrm{mg}), 10 \mathrm{~mol} \%(\boldsymbol{S})-\mathbf{L 1 A u C l}(18.4 \mathrm{mg})$, $20 \mathrm{~mol} \% \mathrm{NaBAr}_{4}{ }_{4}(26.4 \mathrm{mg})$ and $0.4 \mathrm{~mL}$ dry $\mathrm{PhCF}_{3}$ were stirred at $95{ }^{\circ} \mathrm{C}$ for $72 \mathrm{~h}$. The solvent was removed, and the residue was purified by flash column chromatography (hexane/EtOAc = 10:1) to afford cis-2w as a yellow oil (92.1 mg, 86\% yield, d.r.=93/7). ${ }^{\mathbf{1}} \mathbf{H}$ NMR (500 MHz, CDCl$\left._{3}\right) \delta 7.81-7.71(\mathrm{~m}, 1 \mathrm{H}), 7.69(\mathrm{~d}, J=8.3 \mathrm{~Hz}, 2 \mathrm{H}), 7.26-7.18(\mathrm{~m}, 4 \mathrm{H}), 6.84$ (ddd, $J=8.0$, 5.3, 3.8 Hz, 1H), 5.47 (dt, $J=6.3,2.0 \mathrm{~Hz}, 1 \mathrm{H}), 5.38(\mathrm{dt}, J=6.3,2.0 \mathrm{~Hz}, 1 \mathrm{H}), 4.53$ (ddq, $J=8.6$, 5.0, $1.9 \mathrm{~Hz}, 1 \mathrm{H}), 4.29$ (ddq, $J=8.2,3.9,1.9 \mathrm{~Hz}, 1 \mathrm{H}), 3.43(\mathrm{dd}, J=13.2,4.8 \mathrm{~Hz}, 1 \mathrm{H}), 2.96$ (dd, $J$ $=13.1,9.4 \mathrm{~Hz}, 1 \mathrm{H}), 2.33(\mathrm{~s}, 3 \mathrm{H}), 1.77-1.63(\mathrm{~m}, 1 \mathrm{H}), 1.33-1.04(\mathrm{~m}, 11 \mathrm{H}), 0.86-0.79(\mathrm{t}, J=$

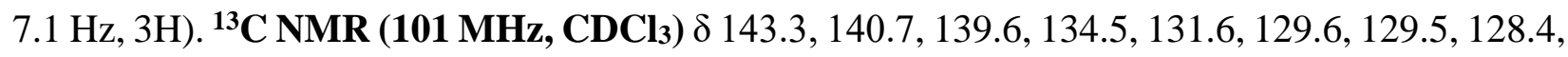
128.1, 127.9, 127.6, 101.0, 48.0, 37.5, 31.8, 29.6, 29.2, 25.4, 22.7, 21.5, 14.1. HRMS (ESI) m/z: $[\mathrm{M}+\mathrm{Na}]^{+}$calcd for $\mathrm{C}_{25} \mathrm{H}_{32} \mathrm{INO}_{2} \mathrm{SNa} 560.1096$; Found $m / z$ 560.1077.

(2S,5R)-2-Benzyl-5-heptyl-1-tosyl-2,5-dihydro-1H-pyrrole (cis-2x)

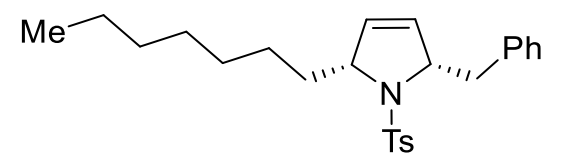

cis-2x

Following the general procedure B, 1x (1.0 mmol, $411.6 \mathrm{mg}), 5 \mathrm{~mol} \%(\mathbf{S})-\mathbf{L 1 A u C l}(46.0 \mathrm{mg}), 10$ mol\% $\mathrm{NaBAr}_{4}(88.0 \mathrm{mg})$ and $2.0 \mathrm{~mL}$ dry toluene were stirred at $110{ }^{\circ} \mathrm{C}$ for $72 \mathrm{~h}$. The solvent was removed, and the residue was purified by flash column chromatography (hexane/EtOAc $=10: 1$ ) to afford cis-2x as a colorless oil (353.6 mg, 86\% yield, d.r. $=93 / 7) .{ }^{1} \mathbf{H}$ NMR (600 MHz, CDCl3) $\delta 7.71(\mathrm{~d}, J=8.3 \mathrm{~Hz}, 2 \mathrm{H}), 7.31-7.26(\mathrm{~m}, 4 \mathrm{H}), 7.23-7.16(\mathrm{~m}, 3 \mathrm{H}), 5.52(\mathrm{dt}, J=6.3,2.0 \mathrm{~Hz}, 1 \mathrm{H})$, $5.44(\mathrm{dt}, J=6.3,2.0 \mathrm{~Hz}, 1 \mathrm{H}), 4.58-4.48(\mathrm{~m}, 1 \mathrm{H}), 4.31-4.23(\mathrm{~m}, 1 \mathrm{H}), 3.30(\mathrm{dd}, J=13.0,3.6 \mathrm{~Hz}$, 1H), $2.83(\mathrm{dd}, J=13.0,9.3 \mathrm{~Hz}, 1 \mathrm{H}), 2.39$ (s, 3H), $1.70-1.63(\mathrm{~m}, 1 \mathrm{H}), 1.39-1.09$ (m, $11 \mathrm{H}), 0.89$ $(\mathrm{t}, J=7.1 \mathrm{~Hz}, 3 \mathrm{H}) .{ }^{13} \mathbf{C} \mathbf{N M R}(\mathbf{1 2 6} \mathbf{M H z}, \mathbf{C D C l}) \delta 143.3,137.4,134.8,130.0,129.6,129.4,128.2$, 128.1, 127.5, 126.5, 69.2, 68.3, 44.1, 37.3, 31.8, 29.5, 29.2, 25.4, 22.6, 21.5, 14.1. HRMS (ESI) $m / z:[\mathrm{M}+\mathrm{Na}]^{+}$calcd for $\mathrm{C}_{25} \mathrm{H}_{33} \mathrm{NO}_{2} \mathrm{SNa} 434.2130$; Found $m / z$ 450.2122. 


\section{Applications}

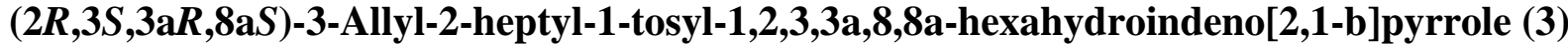

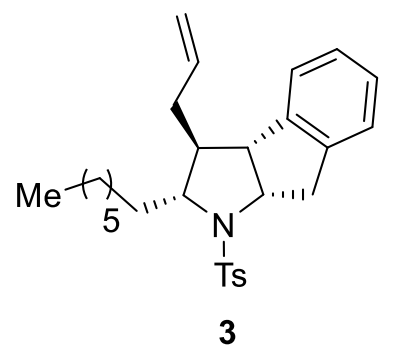

To a solution of the $c i s-\mathbf{2 w}(0.11 \mathrm{mmol}, 52.9 \mathrm{mg})$ in benzene $(1 \mathrm{~mL})$ was added AIBN $(0.022$ mmol, $3.6 \mathrm{mg})$ and allyltributyltin $(0.33 \mathrm{mmol}, 0.11 \mathrm{~mL})$. The reaction was heated to $80{ }^{\circ} \mathrm{C}$ using a metal heating block in a sealed vial for $12 \mathrm{~h}$. The reaction was cooled to room temperature, the solvent evaporated, and the crude product purified by flash chromatography (hexane/EA = 20/1) to afford 3 (31.8 mg, 64\% yield) as a yellow oil. ${ }^{1} \mathbf{H}$ NMR (600 $\left.\mathbf{M H z}, \mathbf{C D C l}_{3}\right) \delta 7.72(\mathrm{~d}, J=8.2$ $\mathrm{Hz}, 2 \mathrm{H}), 7.28$ (d, $J=7.9 \mathrm{~Hz}, 2 \mathrm{H}), 7.16(\mathrm{~d}, J=7.2 \mathrm{~Hz}, 1 \mathrm{H}), 7.14-7.07$ (m, 2H), 7.06 (d, $J=7.2$ $\mathrm{Hz}, 1 \mathrm{H}), 5.49$ (ddt, $J=17.0,10.2,6.8 \mathrm{~Hz}, 1 \mathrm{H}), 4.90$ (d, $J=9.2 \mathrm{~Hz}, 1 \mathrm{fH}), 4.66$ (dq, $J=17.1,1.6$ $\mathrm{Hz}, 1 \mathrm{H}), 4.33(\mathrm{t}, J=6.5 \mathrm{~Hz}, 1 \mathrm{H}), 3.40$ (d, $J=17.2 \mathrm{~Hz}, 1 \mathrm{H}), 3.34(\mathrm{~d}, J=6.9 \mathrm{~Hz}, 1 \mathrm{H}), 3.29$ (dd, $J=$ 10.4, 4.4 Hz, 1H), 3.21 (dd, $J=17.2,6.1 \mathrm{~Hz}, 1 \mathrm{H}), 2.38$ (s, 3H), 2.20 (t, $J=7.7 \mathrm{~Hz}, 1 \mathrm{H}), 1.48-$ $1.43(\mathrm{~m}, 1 \mathrm{H}), 1.35-1.25(\mathrm{~m}, 2 \mathrm{H}), 1.21-1.11(\mathrm{~m}, 3 \mathrm{H}), 1.11-0.90(\mathrm{~m}, 8 \mathrm{H}), 0.78(\mathrm{t}, J=7.3 \mathrm{~Hz}$, 3H). ${ }^{13} \mathbf{C}$ NMR (126 MHz, CDCl 3$) \delta 144.1,143.3,141.4,135.9,135.5,129.6,127.7,127.4,126.7$, 125.3, 123.4, 117.1, 67.1, 64.2, 55.0, 47.3, 41.8, 38.6, 36.8, 31.7, 29.1, 28.9, 26.3, 22.6, 21.5, 14.1. HRMS (ESI) $m / z$ : $[\mathrm{M}+\mathrm{Na}]^{+}$calcd for $\mathrm{C}_{28} \mathrm{H}_{37} \mathrm{NO}_{2} \mathrm{SNa}$ 474.2443; Found $m / z$ 474.2431.

(2R,3S,3aR,8aS)-2-Heptyl-1-tosyl-1,2,3,3a,8,8a-hexahydroindeno[2,1-b]pyrrol-3-ol (4)

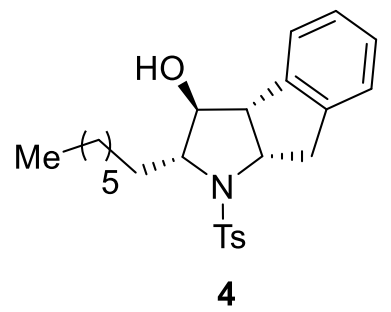

A solution of $c i s-2 w(38.3 \mathrm{mg}, 0.071 \mathrm{mmol})$ in anhydrous toluene $(2.4 \mathrm{~mL})$ was treated with a solution of TEMPO (32 mg, $0.22 \mathrm{mmol})$ in toluene $(0.2 \mathrm{~mL})$ and (TMS $)_{3} \mathrm{SiH}(22 \mu \mathrm{L}, 74 \mu \mathrm{mol})$. The solution was warmed to $80{ }^{\circ} \mathrm{C}$, TEMPO $(2 \times 28 \mathrm{mg}$ in $0.6 \mathrm{~mL}$ toluene $)$ and $(\mathrm{TMS})_{3} \mathrm{SiH}(4 \times$ 
$22 \mu \mathrm{L}$ ) were added in portions over the next $4 \mathrm{~h}$. After $16 \mathrm{~h}$, the reaction mixture was cooled to room temperature, and the solvent was removed under reduced pressure. The crude product was purified via chromatography (hexane/EA $=5 / 1)$ to afford a brown oil $(42.7 \mathrm{mg})$. The brown oil was dissolved in a 3:1 mixture of THF- $\mathrm{H}_{2} \mathrm{O}(0.9 \mathrm{~mL})$ and treated with activated zinc powder (54 $\mathrm{mg}, 0.8 \mathrm{mmol})$ and HOAc $(0.2 \mathrm{~mL})$. The resulting suspension was warmed to $60{ }^{\circ} \mathrm{C}$ with vigorous stirring. After $12 \mathrm{~h}$, additional Zn (54 mg) was added, and the reaction was stirred for $12 \mathrm{~h}$. The zinc power was removed by filtration through Celite and washed with DCM. The solvent was removed under reduced pressure, and the resulting mixture was purified by chromatography (hexane/EA = 4/1) to afford 4 as light brown oil (14.4 mg, 54\% yield). ${ }^{1} \mathbf{H}$ NMR (500 $\left.\mathbf{~ M H z , ~ C D C l}\right)$ $\delta 7.85(\mathrm{~d}, J=8.3 \mathrm{~Hz}, 2 \mathrm{H}), 7.37(\mathrm{~d}, J=8.0 \mathrm{~Hz}, 2 \mathrm{H}), 7.28-7.16(\mathrm{~m}, 4 \mathrm{H}), 4.60(\mathrm{td}, J=6.6,1.2 \mathrm{~Hz}$, 1H), 4.34 (s, 1H), 3.71 (dd, $J=7.0,1.3 \mathrm{~Hz}, 1 \mathrm{H}), 3.63(\mathrm{ddd}, J=9.8,5.6,1.3 \mathrm{~Hz}, 1 \mathrm{H}), 3.42(\mathrm{~d}, J=$ $17.2 \mathrm{~Hz}, 1 \mathrm{H}), 3.33(\mathrm{dd}, J=17.3,6.2 \mathrm{~Hz}, 1 \mathrm{H}), 2.46(\mathrm{~s}, 3 \mathrm{H}), 1.37-1.12(\mathrm{~m}, 12 \mathrm{H}), 0.87$ (t, $J=7.2$ $\mathrm{Hz}, 3 \mathrm{H}) .{ }^{13} \mathrm{C}$ NMR (126 MHz, $\left.\mathbf{C D C l}_{3}\right) \delta$ 143.6, 141.8, 140.6, 135.2, 129.6, 127.9, 127.8, 126.9, 125.6, 123.8, 78.7, 77.3, 71.3, 63.6, 58.9, 41.8, 34.6, 31.6, 29.0, 28.8, 26.2, 22.6, 21.6, 14.1.

HRMS (ESI) $m / z:$ : $[\mathrm{M}+\mathrm{Na}]^{+}$calcd for $\mathrm{C}_{25} \mathrm{H}_{33} \mathrm{NO}_{3} \mathrm{SNa} 450.2079$; Found $m / z$ 450.2067.

\section{$(2 S, 4 R, 5 R)$-2-Benzyl-4-heptyl-3-tosyl-6-oxa-3-azabicyclo[3.1.0]hexane (5)}

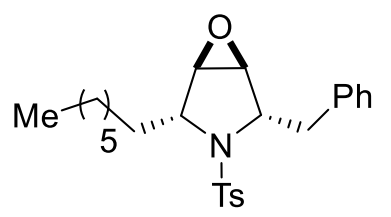

5

To a solution of cis-2x (138.1 mg, $0.34 \mathrm{mmol})$ in $3 \mathrm{~mL}$ DCM was added $m$ CPBA (70\%, 2 equiv., $165 \mathrm{mg}$ ) and the reaction mixture was stirred at room temperature for $24 \mathrm{~h}$. Upon completion, the reaction was diluted with $\mathrm{DCM}$ and wash with $\mathrm{NaHCO}_{3}$ and brine. The organic layer was dried over $\mathrm{Na}_{2} \mathrm{SO}_{4}$, and the solvent was removed under reduced pressure. The crude product was purified via chromatography (hexane/EA = 10/1) to afford 5 as a colorless oil (104.1 mg, 75\% yield). ${ }^{\mathbf{1}} \mathbf{H}$ NMR (600 MHz, CDCl3) $\delta 7.59(\mathrm{~d}, J=8.3 \mathrm{~Hz}, 2 \mathrm{H}), 7.25(\mathrm{~d}, J=7.6 \mathrm{~Hz}, 2 \mathrm{H}), 7.23-7.18(\mathrm{~m}, 5 \mathrm{H})$, $3.89(\mathrm{dd}, J=10.6,3.8 \mathrm{~Hz}, 1 \mathrm{H}), 3.66(\mathrm{dd}, J=8.8,5.7 \mathrm{~Hz}, 1 \mathrm{H}), 3.28-3.21(\mathrm{~m}, 3 \mathrm{H}), 2.72(\mathrm{dd}, J=$ 13.7, 10.6 Hz, 1H), 2.33 (s, 3H), $1.65-1.57$ (m, 1H), $1.46-1.13(\mathrm{~m}, 12 \mathrm{H}), 0.83$ (t, J = 7.0 Hz, 3H). ${ }^{13}$ C NMR (101 MHz, CDCl3) $\delta 143.4,137.1,135.1,129.5,129.4,128.7,127.7,126.9,62.5$, 
61.6, 58.4, 57.6, 40.8, 34.0, 31.8, 29.5, 29.1, 26.3, 22.6, 21.6, 14.1. HRMS (ESI) $\mathrm{m} / z:[\mathrm{M}+\mathrm{Na}]^{+}$ calcd for $\mathrm{C}_{25} \mathrm{H}_{33} \mathrm{NO}_{3} \mathrm{SNa}$ 450.2079; Found $m / z$ 450.2073.

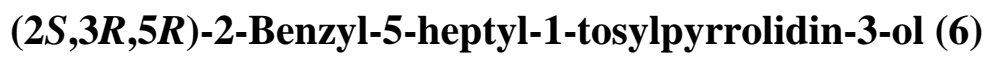

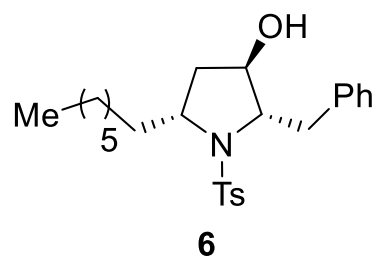

To a solution of $5(187.7 \mathrm{mg}, 0.44 \mathrm{mmol})$ in $5 \mathrm{~mL}$ THF solution under $\mathrm{N}_{2}$ protection with an ethylene glycol/dry ice cooling bath, $\mathrm{LiBHEt}_{3}(1.7 \mathrm{M}, 2.6 \mathrm{ml}, 10$ equiv.) was added slowly, and the reaction was stirred for $18 \mathrm{~h}$. Upon completion, the reaction was quench by slowly adding water and extract with $\mathrm{Et}_{2} \mathrm{O}$ three times. The organic layer was washed with brine and dried over $\mathrm{Na}_{2} \mathrm{SO}_{4}$. The solvent was removed under reduced pressure, and the resulting crude product was purified via chromatography (hexane/EA $=3 / 1)$ to afford $\mathbf{6}$ as a colorless oil $(142.2 \mathrm{mg}, 76 \%$ yield, $r r=84 / 16) .{ }^{1} \mathbf{H}$ NMR $\left(600 \mathrm{MHz}, \mathbf{C D C l}_{3}\right) \delta 7.69(\mathrm{~d}, \mathrm{~J}=8.3 \mathrm{~Hz}, 2 \mathrm{H}), 7.23(\mathrm{td}, \mathrm{J}=7.4,1.7 \mathrm{~Hz}, 4 \mathrm{H})$, $7.18-7.12(\mathrm{~m}, 3 \mathrm{H}), 3.96-3.89$ (m, 1H), $3.68-3.54(\mathrm{~m}, 2 \mathrm{H}), 3.11(\mathrm{dd}, \mathrm{J}=13.7,4.1 \mathrm{~Hz}, 1 \mathrm{H})$, $2.56(\mathrm{dd}, \mathrm{J}=13.7,10.2 \mathrm{~Hz}, 1 \mathrm{H}), 2.34(\mathrm{~d}, \mathrm{~J}=7.3 \mathrm{~Hz}, 3 \mathrm{H}), 2.00-1.89(\mathrm{~m}, 1 \mathrm{H}), 1.80-1.67(\mathrm{~m}$, 1H), $1.67-1.59(\mathrm{~m}, 1 \mathrm{H}), 1.40-1.30(\mathrm{~m}, 1 \mathrm{H}), 1.29-1.08(\mathrm{~m}, 10 \mathrm{H}), 0.83(\mathrm{t}, \mathrm{J}=7.1 \mathrm{~Hz}, 3 \mathrm{H}) .{ }^{13} \mathrm{C}$ NMR (126 MHz, $\left.\mathbf{C D C l}_{3}\right) \delta$ 143.5, 137.7, 134.6, 129.5, 129.5, 128.6, 127.8, 126.7, 72.8, 71.00, 59.8, 42.0, 38.2, 36.9, 31.8, 29.5, 29.2, 25.9, 22.6, 21.5, 14.1. HRMS (ESI) $m / z:[\mathrm{M}+\mathrm{Na}]^{+}$calcd for $\mathrm{C}_{25} \mathrm{H}_{35} \mathrm{NO}_{3} \mathrm{SNa} 452.2235$, found $\mathrm{m} / 2452.2219$.

(2S,5R)-2-Benzyl-5-heptyl-1-tosylpyrrolidin-3-one (7)

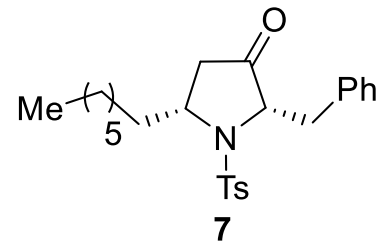

To a solution of 6 (102.2 $\mathrm{mg}, 0.24 \mathrm{mmol})$ in $5 \mathrm{~mL}$ DCM was added Dess-Martin periodinane (407.2 mg, 4.0 equiv.) and the reaction was heated to $40{ }^{\circ} \mathrm{C}$ using a heating block for $24 \mathrm{~h}$. Upon Completion, the reaction was cooled down to room temperature and diluted with DCM. The organic layer was washed with $\mathrm{NaHCO}_{3}$ and brine. The solvent was removed under vacuum and 
the crude product was purified via chromatography (hexane/EA $=10 / 1$ ) to afford 7 as a colorless oil (77.3 mg, 76\%,rr = 84/16). ${ }^{1} \mathbf{H}$ NMR (600 MHz, $\left.\mathbf{C D C l}_{3}\right) \delta 7.72(\mathrm{~d}, J=8.2 \mathrm{~Hz}, 2 \mathrm{H}), 7.32(\mathrm{~d}$, $J=8.2 \mathrm{~Hz}, 2 \mathrm{H}), 7.32-7.17(\mathrm{~m}, 5 \mathrm{H}), 3.97-3.90(\mathrm{~m}, 1 \mathrm{H}), 3.87-3.77(\mathrm{~m}, 1 \mathrm{H}), 3.28-3.19(\mathrm{~m}$, 2H), $2.42(\mathrm{~s}, 3 \mathrm{H}), 2.17-2.06(\mathrm{~m}, 1 \mathrm{H}), 1.80-1.67(\mathrm{~m}, 1 \mathrm{H}), 1.38-0.92(\mathrm{~m}, 11 \mathrm{H}), 0.88(\mathrm{t}, J=7.2$ $\mathrm{Hz}, 3 \mathrm{H}), 0.49-0.35$ (m, 1H). ${ }^{13} \mathbf{C}$ NMR (126 MHz, CDCl $) \delta 211.2,144.1,136.2,134.1,130.9$, 130.00, 128.1, 127.4, 126.8, 65.4, 56.8, 42.2, 37.9, 37.0, 31.7, 29.0, 28.9, 25.8, 22.6, 21.5, 14.0. HRMS (ESI) $m / z:[\mathrm{M}+\mathrm{Na}]^{+}$calcd for $\mathrm{C}_{25} \mathrm{H}_{33} \mathrm{NO}_{3} \mathrm{SNa} 450.2079$; Found $m / z 450.2073$. 


\section{X-ray Structure of cis-2a}

The crystal was obtained by slow evaporation of $\operatorname{cis}-\mathbf{2 a}$ in a mixture of DCM/hexane (1/1) and measured at $200 \mathrm{~K}$ using Kappa apex II diffractometer

Crystallographic data for cis-2a have been deposited at the Cambridge Crystallographic Data Centre, under deposition numbers CCDC 1992021. Copies of the data can be obtained free of charge via www.ccdc.cam.ac.uk/data_request/cif.

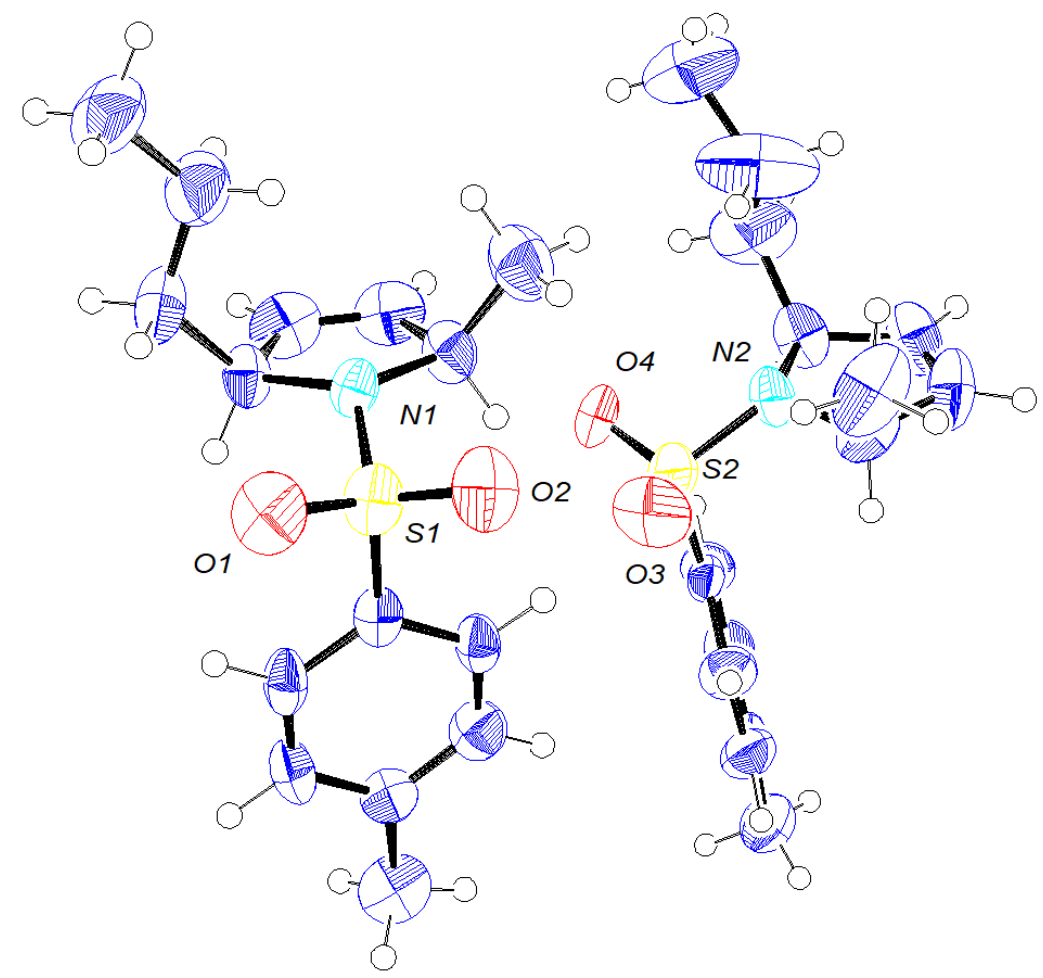

thermal ellipsoids at the $50 \%$ probability level

Bond precision: $\quad \mathrm{C}-\mathrm{C}=0.0156 \mathrm{~A} \quad$ Wavelength $=0.71073$

Cell: $\quad \mathrm{a}=12.239(9) \quad \mathrm{b}=7.458(6) \quad \mathrm{c}=17.042(12)$

$$
\text { alpha }=90 \quad \text { beta }=97.27(2) \quad \text { gamma }=90
$$

Temperature: $200 \mathrm{~K}$

Calculated

Volume

Space group
$1543(2)$

P 21
Reported

$1542.9(19)$

P 21 


\begin{tabular}{|c|c|c|}
\hline Hall group & $\mathrm{P} 2 \mathrm{yb}$ & $\mathrm{P} 2 \mathrm{yb}$ \\
\hline Moiety formula & $\mathrm{C} 15 \mathrm{H} 21 \mathrm{~N} \mathrm{O} 2 \mathrm{~S}$ & $?$ \\
\hline Sum formula & $\mathrm{C} 15 \mathrm{H} 21 \mathrm{~N} \mathrm{O} 2 \mathrm{~S}$ & $\mathrm{C} 15 \mathrm{H} 21 \mathrm{~N} \mathrm{O} 2 \mathrm{~S}$ \\
\hline $\mathrm{Mr}$ & 279.39 & 279.39 \\
\hline Dx,g cm-3 & 1.203 & 1.203 \\
\hline $\mathrm{Z}$ & 4 & 4 \\
\hline $\mathrm{Mu}(\mathrm{mm}-1)$ & 0.208 & 0.208 \\
\hline F000 & 600.0 & 600.0 \\
\hline F000' & 600.73 & \\
\hline $\mathrm{h}, \mathrm{k}, \operatorname{lmax}$ & $14,8,19$ & $14,8,19$ \\
\hline Nref & $5111[2775]$ & 4762 \\
\hline Tmin,Tmax & $0.963,0.990$ & $0.567,0.745$ \\
\hline Tmin' & 0.959 & \\
\hline \multicolumn{3}{|c|}{ Correction method $=\#$ Reported T Limits: Tmin $=0.567$ Tmax $=0.745$} \\
\hline \multicolumn{3}{|c|}{ AbsCorr $=$ MULTI-SCAN } \\
\hline \multicolumn{2}{|c|}{ Data completeness $=1.72 / 0.93$} & \\
\hline \multicolumn{2}{|c|}{$\mathrm{R}($ reflections $)=0.0676(2373)$} & $=0.1554(4762)$ \\
\hline$S=0.965$ & Npar $=349$ & \\
\hline
\end{tabular}

\section{Reference}

1. Cheng, X.; Wang, Z.; Quintanilla, C. D.; Zhang, L., Chiral Bifunctional Phosphine Ligand Enabling Gold-Catalyzed Asymmetric Isomerization of Alkyne to Allene and Asymmetric Synthesis of 2,5-Dihydrofuran. J. Am. Chem. Soc. 2019, 141 (9), 3787-3791. 
2. Li, T.; Cheng, X.; Qian, P.; Zhang, L., Gold-Catalysed Asymmetric Net Addition of Unactivated Propargylic C-H Bonds to Tethered Aldehydes. Nat. Catal. 2021, 4 (2), 164-171.

3. Wang, Z.; Ying, A.; Fan, Z.; Hervieu, C.; Zhang, L., Tertiary Amino Group in Cationic Gold Catalyst: Tethered Frustrated Lewis Pairs That Enable Ligand-Controlled Regiodivergent and Stereoselective Isomerizations of Propargylic Esters. ACS Catal. 2017, 7 (5), 3676-3680.

4. Liu, G.; Cogan, D. A.; Ellman, J. A., Catalytic Asymmetric Synthesis of tertButanesulfinamide. Application to the Asymmetric Synthesis of Amines. J. Am. Chem. Soc. 1997, 119 (41), 9913-9914.

5. Liu, G.; Cogan, D. A.; Owens, T. D.; Tang, T. P.; Ellman, J. A., Synthesis of Enantiomerically Pure N-tert-Butanesulfinyl Imines (tert-Butanesulfinimines) by the Direct Condensation of tert-Butanesulfinamide with Aldehydes and Ketones. J. Org. Chem. 1999, 64 (4), 1278-1284.

6. Chen, B.-L.; Wang, B.; Lin, G.-Q., Highly Diastereoselective Addition of Alkynylmagnesium Chlorides to N-tert-Butanesulfinyl Aldimines: A Practical and General Access to Chiral $\alpha$-Branched Amines. J. Org. Chem. 2010, 75 (3), 941-944.

7. $\quad$ Chen, W.; Ren, J.; Wang, M.; Dang, L.; Shen, X.; Yang, X.; Zhang, H., Iodine Mediated Deprotection of N-tert-Butanesulfinyl Amines: A Functional Group Compatible Method. ChemComm 2014, 50 (47), 6259-6262.

8. $\quad$ Bai, X.-F.; Mu, Q.-C.; Xu, Z.; Yang, K.-F.; Li, L.; Zheng, Z.-J.; Xia, C.-G.; Xu, L.-W., Catalytic Asymmetric Carbonylation of Prochiral Sulfonamides via $\mathrm{C}-\mathrm{H}$ Desymmetrization. ACS Catal. 2019, 9 (2), 1431-1436.

9. García-Rubia, A.; Romero-Revilla, J. A.; Mauleón, P.; Gómez Arrayás, R.; Carretero, J. C., Cu-Catalyzed Silylation of Alkynes: A Traceless 2-Pyridylsulfonyl Controller Allows Access to Either Regioisomer on Demand. J. Am. Chem. Soc. 2015, 137 (21), 6857-6865.

10. Shin, Y. H.; Maheswara, M.; Hwang, J. Y.; Kang, E. J., Copper-Catalyzed Domino Homologation and Cycloisomerization Reactions for 3-Pyrroline Synthesis. Eur. J. Org. Chem. 2014, 2014 (11), 2305-2311.

\section{HPLC Spectrum}




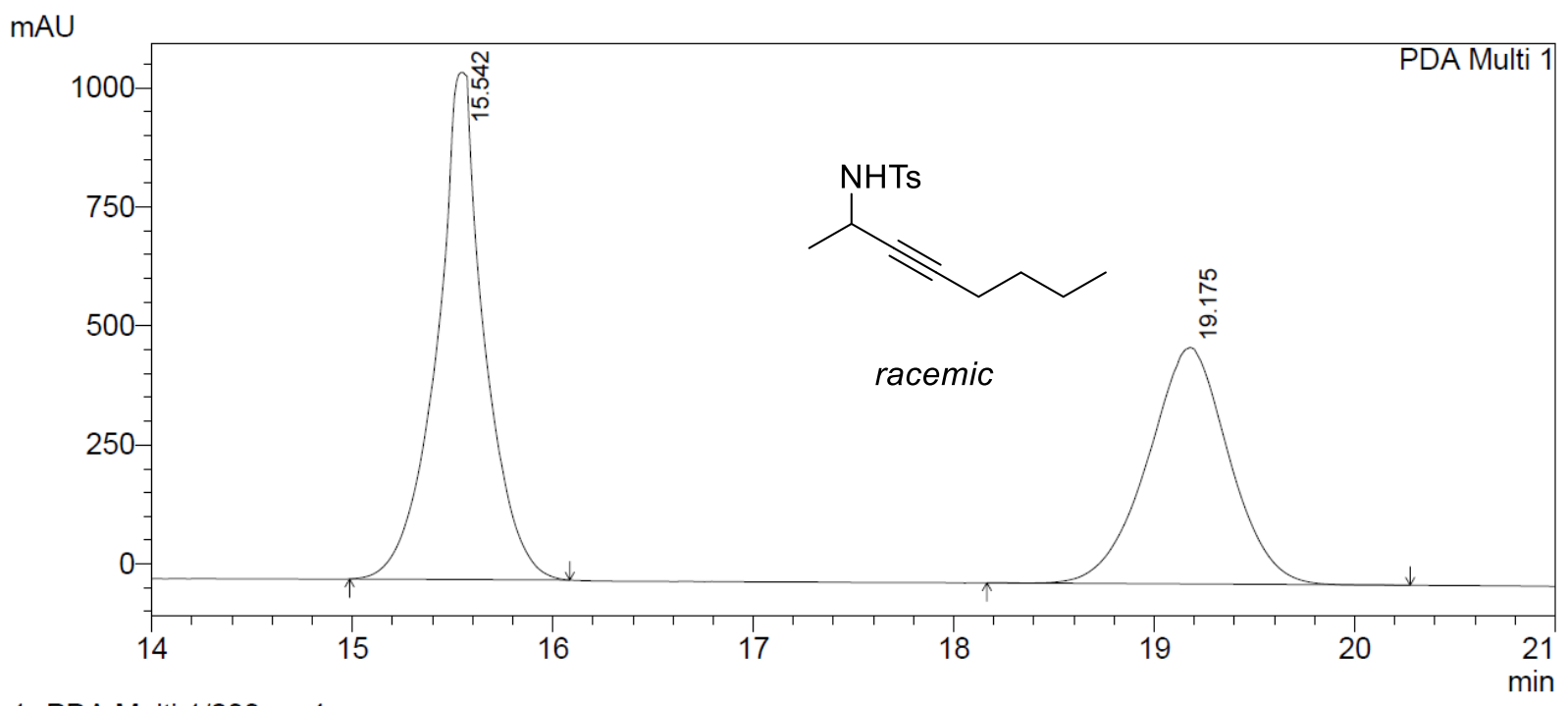

1 PDA Multi 1/200nm 4nm

PeakTable

\begin{tabular}{|r|r|r|r|r|r|}
\hline \multicolumn{1}{|c|}{ Peak\# } & Ret. Time & Area & Height & Area \% & \multicolumn{1}{|c|}{ Height \% } \\
\hline 1 & 15.542 & 17650187 & 1065374 & 55.786 & 68.194 \\
\hline 2 & 19.175 & 13988760 & 496899 & 44.214 & 31.806 \\
\hline Total & & 31638947 & 1562273 & 100.000 & 100.000 \\
\hline
\end{tabular}

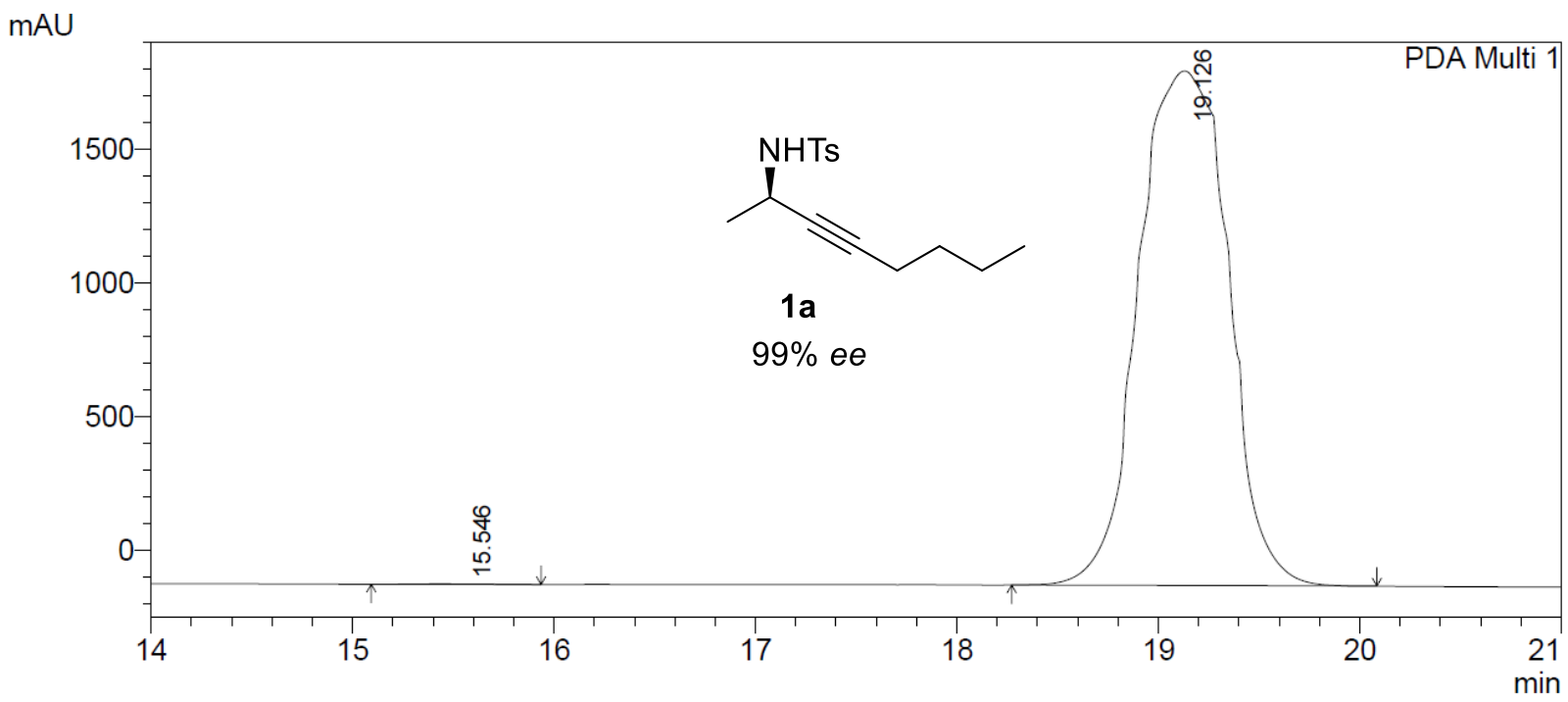

1 PDA Multi 1/202nm 4nm

PeakTable

PDA Ch1 202nm 4nm

\begin{tabular}{|r|r|r|r|r|r|}
\hline \multicolumn{1}{|c|}{ Peak\# } & Ret. Time & \multicolumn{1}{c|}{ Area } & \multicolumn{1}{c|}{ Height } & \multicolumn{1}{|c|}{ Area \% } & \multicolumn{1}{c|}{ Height \% } \\
\hline 1 & 15.546 & 49984 & 2683 & 0.084 & 0.139 \\
\hline 2 & 19.126 & 59461030 & 1925016 & 99.916 & 99.861 \\
\hline Total & & 59511014 & 1927699 & 100.000 & 100.000 \\
\hline
\end{tabular}




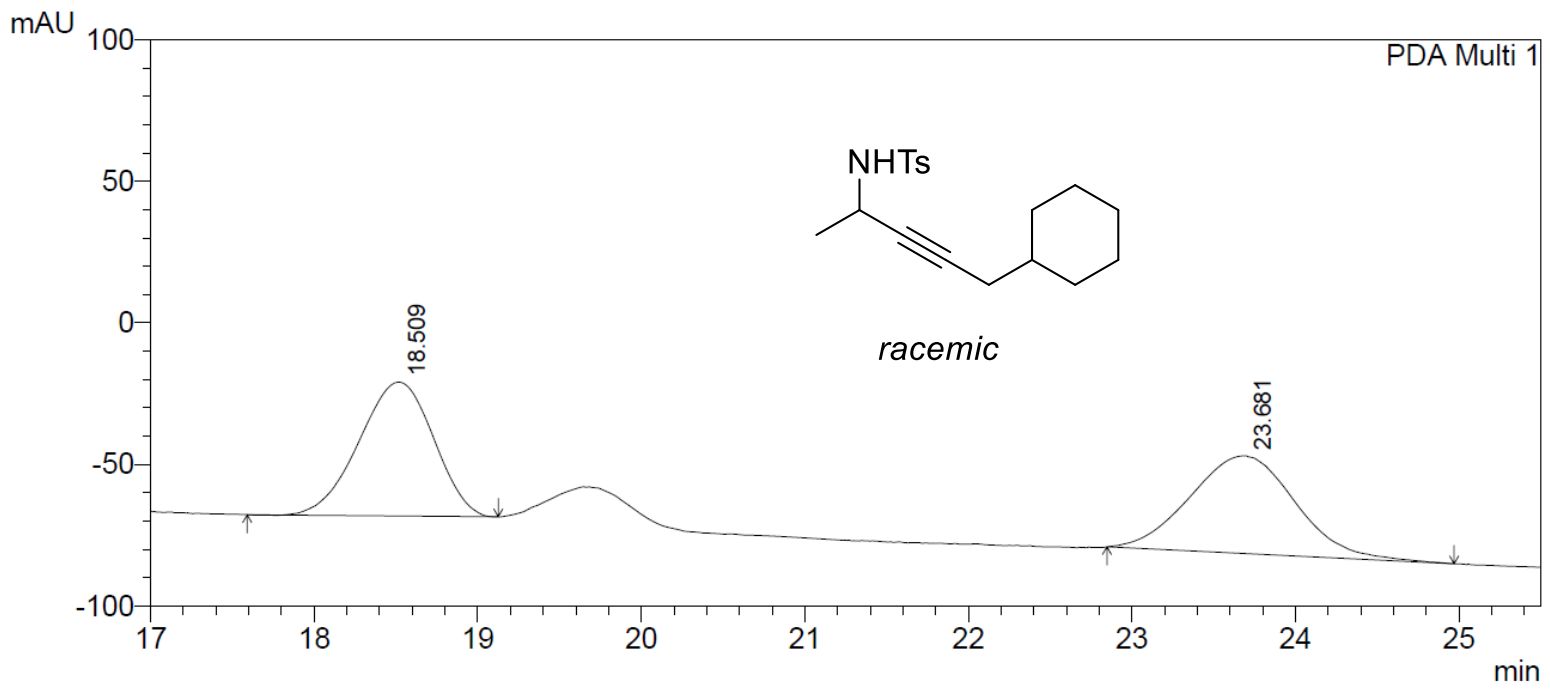

1 PDA Multi $1 / 205 \mathrm{~nm} 4 \mathrm{~nm}$

PeakTable

PDA Ch1 205nm 4nm

\begin{tabular}{|r|r|r|r|r|r|}
\hline \multicolumn{1}{|c|}{ Peak\# } & Ret. Time & \multicolumn{1}{c|}{ Area } & \multicolumn{1}{c|}{ Height } & \multicolumn{1}{c|}{ Area \% } & \multicolumn{1}{c|}{ Height \% } \\
\hline 1 & 18.509 & 1495894 & 47287 & 49.302 & 57.820 \\
\hline 2 & 23.681 & 1538278 & 34496 & 50.698 & 42.180 \\
\hline Total & & 3034172 & 81783 & 100.000 & 100.000 \\
\hline
\end{tabular}

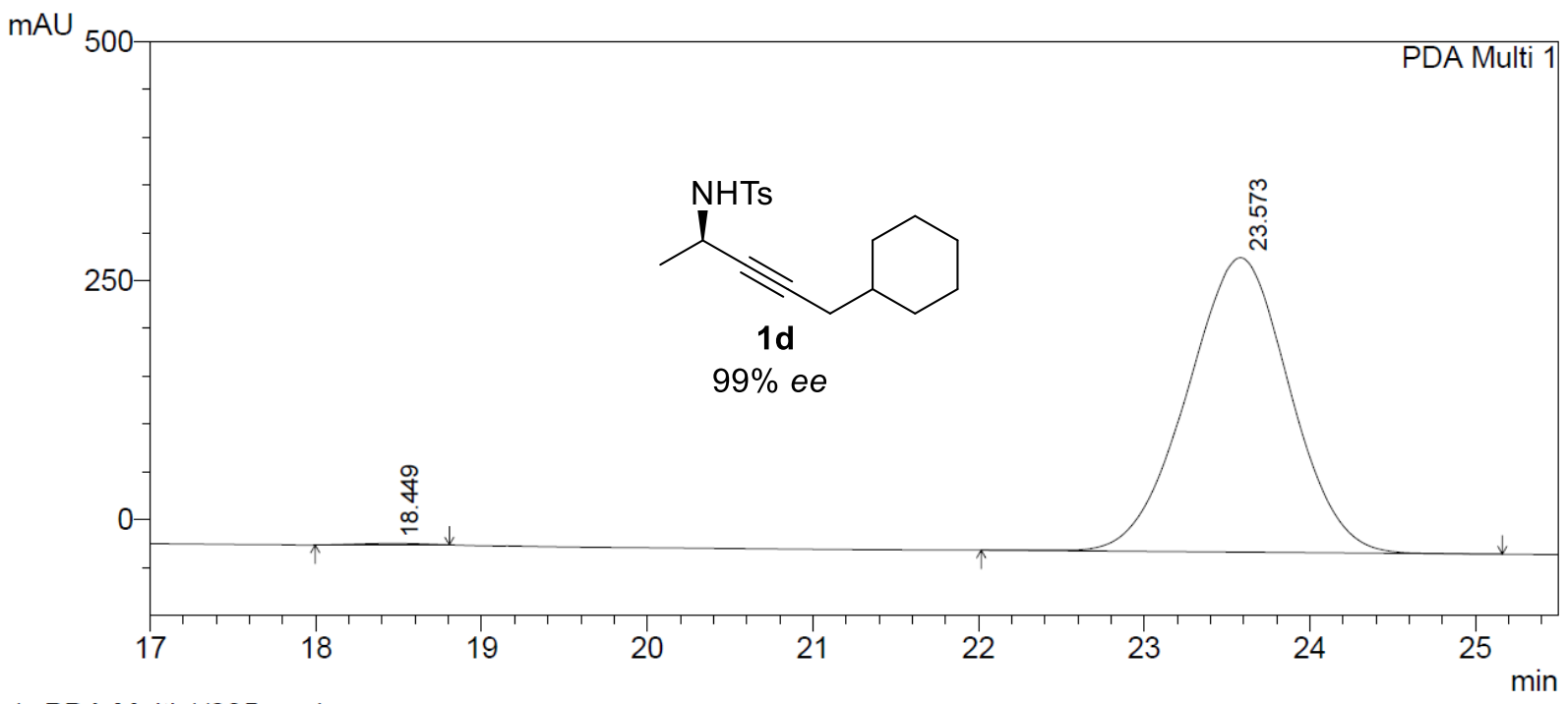

1 PDA Multi 1/205nm 4nm

PDA Ch1 205nm 4nm

PeakTable

\begin{tabular}{|r|r|r|r|r|r|}
\hline \multicolumn{1}{|c|}{ Peak\# } & Ret. Time & \multicolumn{1}{|c|}{ Area } & \multicolumn{1}{|c|}{ Height } & \multicolumn{1}{c|}{ Area \% } & \multicolumn{1}{c|}{ Height \% } \\
\hline 1 & 18.449 & 44453 & 1798 & 0.334 & 0.580 \\
\hline 2 & 23.573 & 13257351 & 308042 & 99.666 & 99.420 \\
\hline Total & & 13301804 & 309840 & 100.000 & 100.000 \\
\hline
\end{tabular}




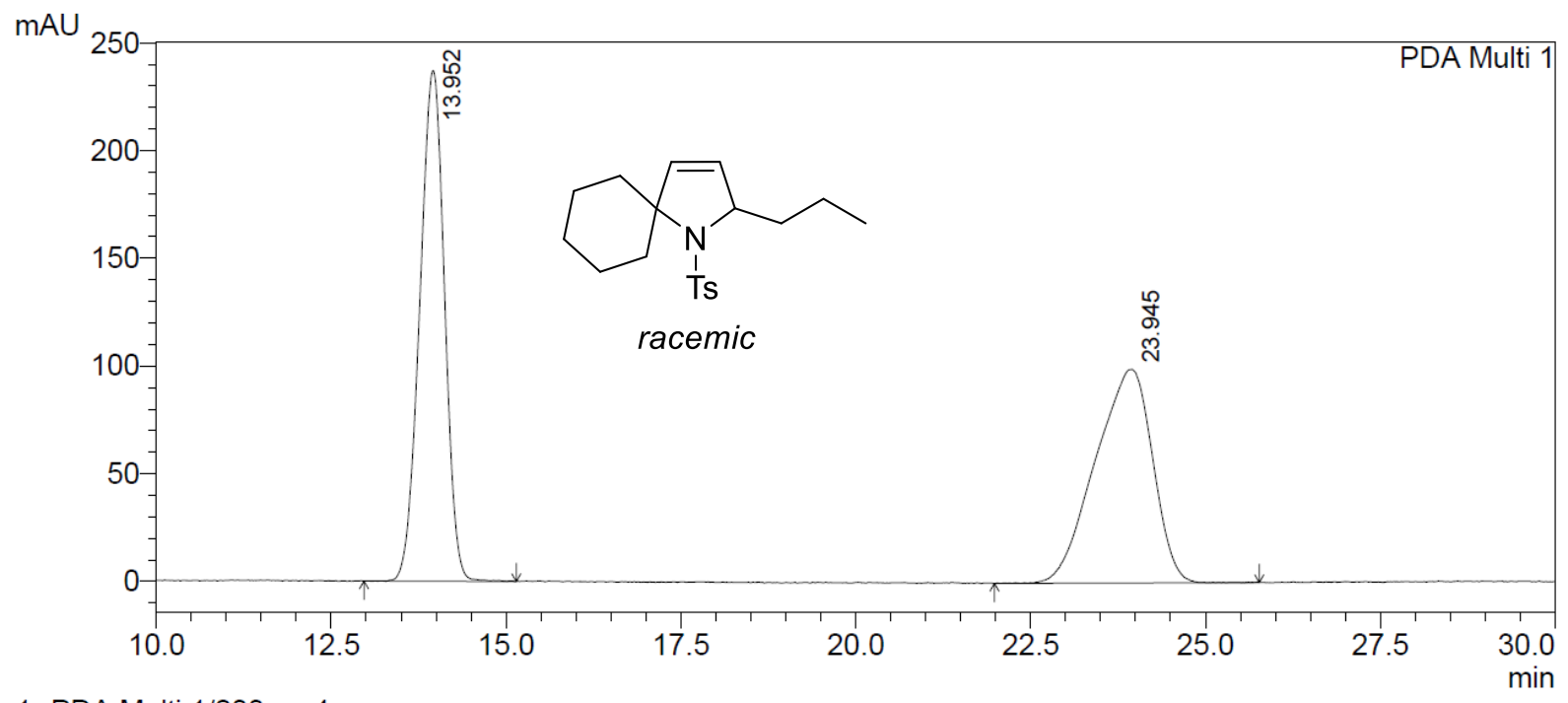

1 PDA Multi 1/200nm 4nm

PeakTable

PDA Ch1 200nm 4nm

\begin{tabular}{|r|r|r|r|r|r|}
\hline \multicolumn{1}{|c|}{ Peak\# } & Ret. Time & \multicolumn{1}{c|}{ Area } & \multicolumn{1}{c|}{ Height } & \multicolumn{1}{c|}{ Area \% } & \multicolumn{1}{c|}{ Height \% } \\
\hline 1 & 13.952 & 5841171 & 237093 & 50.780 & 70.488 \\
\hline 2 & 23.945 & 5661715 & 99266 & 49.220 & 29.512 \\
\hline Total & & 11502886 & 336359 & 100.000 & 100.000 \\
\hline
\end{tabular}

mAU

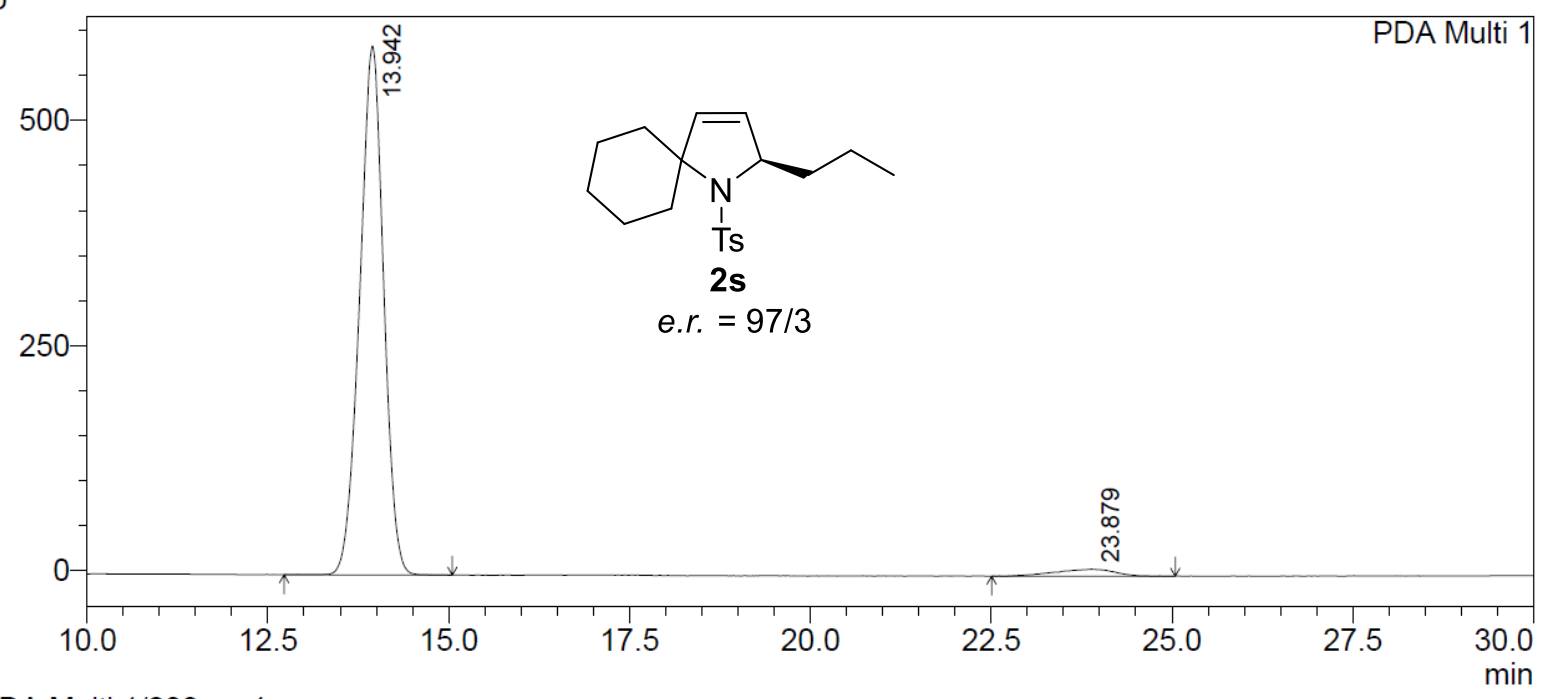

1 PDA Multi 1/200nm 4nm

PeakTable

PDA Ch1 200nm 4nm

\begin{tabular}{|r|r|r|r|r|r|}
\hline \multicolumn{1}{|c|}{ Peak\# } & \multicolumn{1}{|c|}{ Ret. Time } & \multicolumn{1}{c|}{ Area } & \multicolumn{1}{c|}{ Height } & \multicolumn{1}{c|}{ Area \% } & \multicolumn{1}{c|}{ Height \% } \\
\hline 1 & 13.942 & 13517288 & 587138 & 96.884 & 98.706 \\
\hline 2 & 23.879 & 434739 & 7699 & 3.116 & 1.294 \\
\hline Total & & 13952027 & 594837 & 100.000 & 100.000 \\
\hline
\end{tabular}




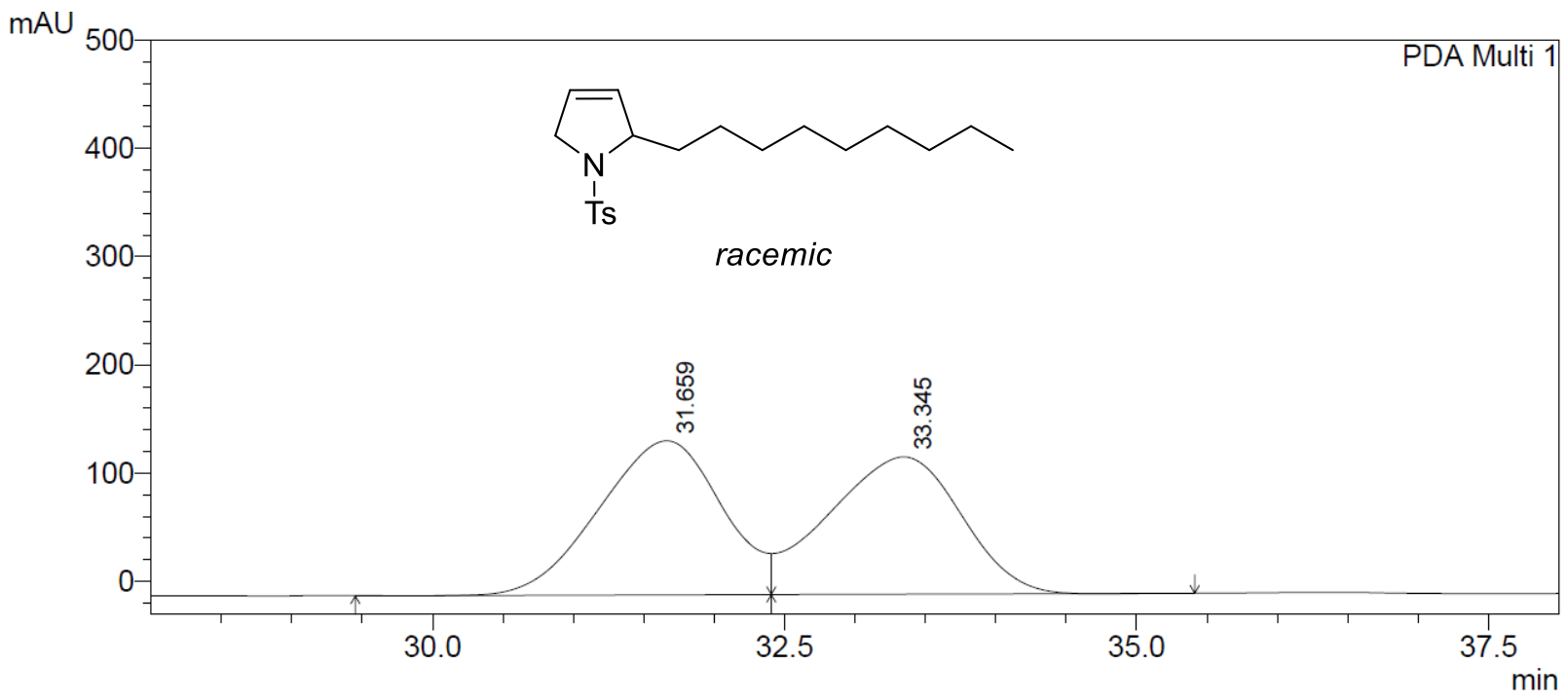

1 PDA Multi 1/200nm 4nm

PDA Ch1 200nm 4nm

\begin{tabular}{|r|r|r|r|r|r|}
\hline Peak\# & Ret. Time & \multicolumn{1}{|c|}{ Area } & \multicolumn{1}{c|}{ Height } & \multicolumn{1}{c|}{ Area \% } & \multicolumn{1}{c|}{ Height \% } \\
\hline 1 & 31.659 & 8655191 & 142373 & 51.048 & 52.883 \\
\hline 2 & 33.345 & 8299796 & 126850 & 48.952 & 47.117 \\
\hline Total & & 16954987 & 269222 & 100.000 & 100.000 \\
\hline
\end{tabular}

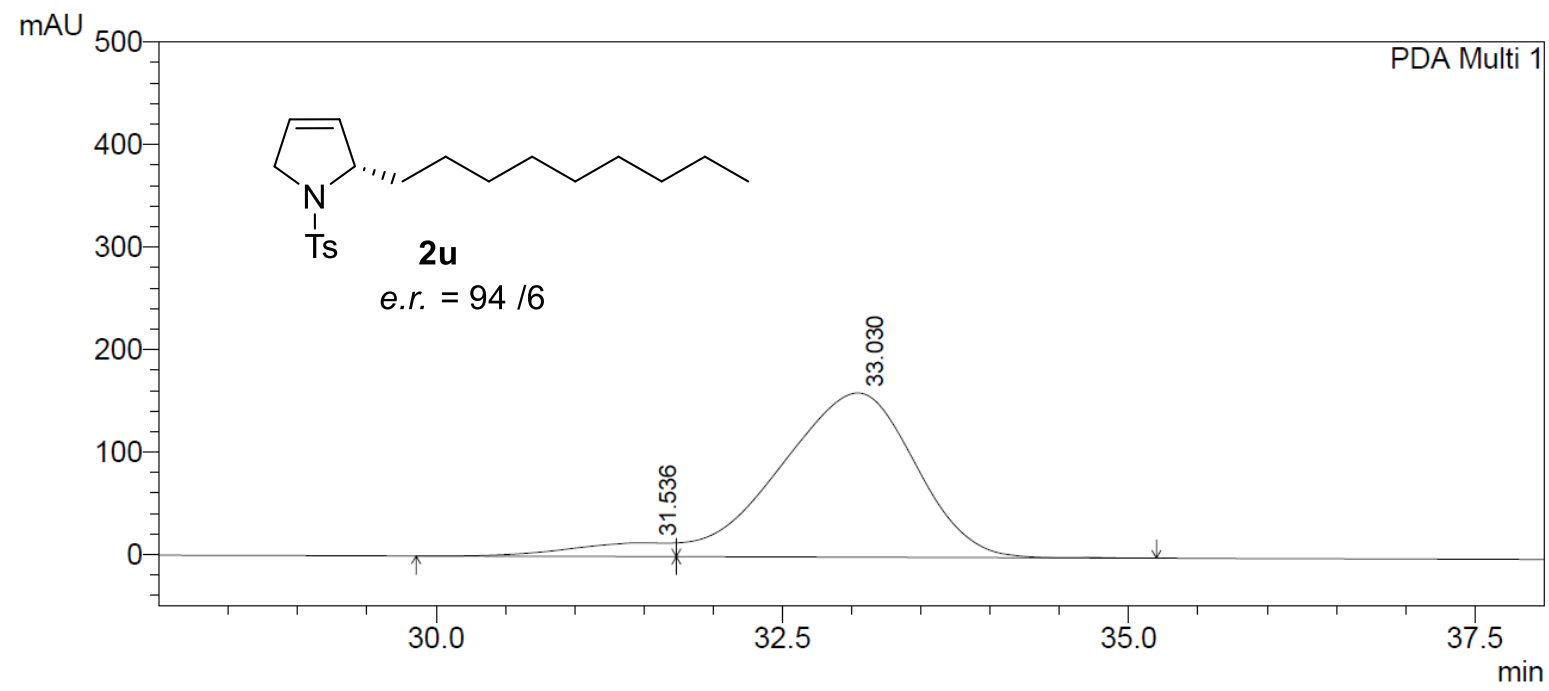

1 PDA Multi 1/200nm 4nm

PeakTable

PDA Ch1 200nm 4nm

\begin{tabular}{|r|r|r|r|r|r|}
\hline \multicolumn{1}{|c|}{ Peak\# } & Ret. Time & \multicolumn{1}{c|}{ Area } & \multicolumn{1}{c|}{ Height } & \multicolumn{1}{c|}{ Area \% } & \multicolumn{1}{c|}{ Height \% } \\
\hline 1 & 31.536 & 675291 & 13513 & 5.870 & 7.775 \\
\hline 2 & 33.030 & 10828057 & 160273 & 94.130 & 92.225 \\
\hline Total & & 11503349 & 173785 & 100.000 & 100.000 \\
\hline
\end{tabular}




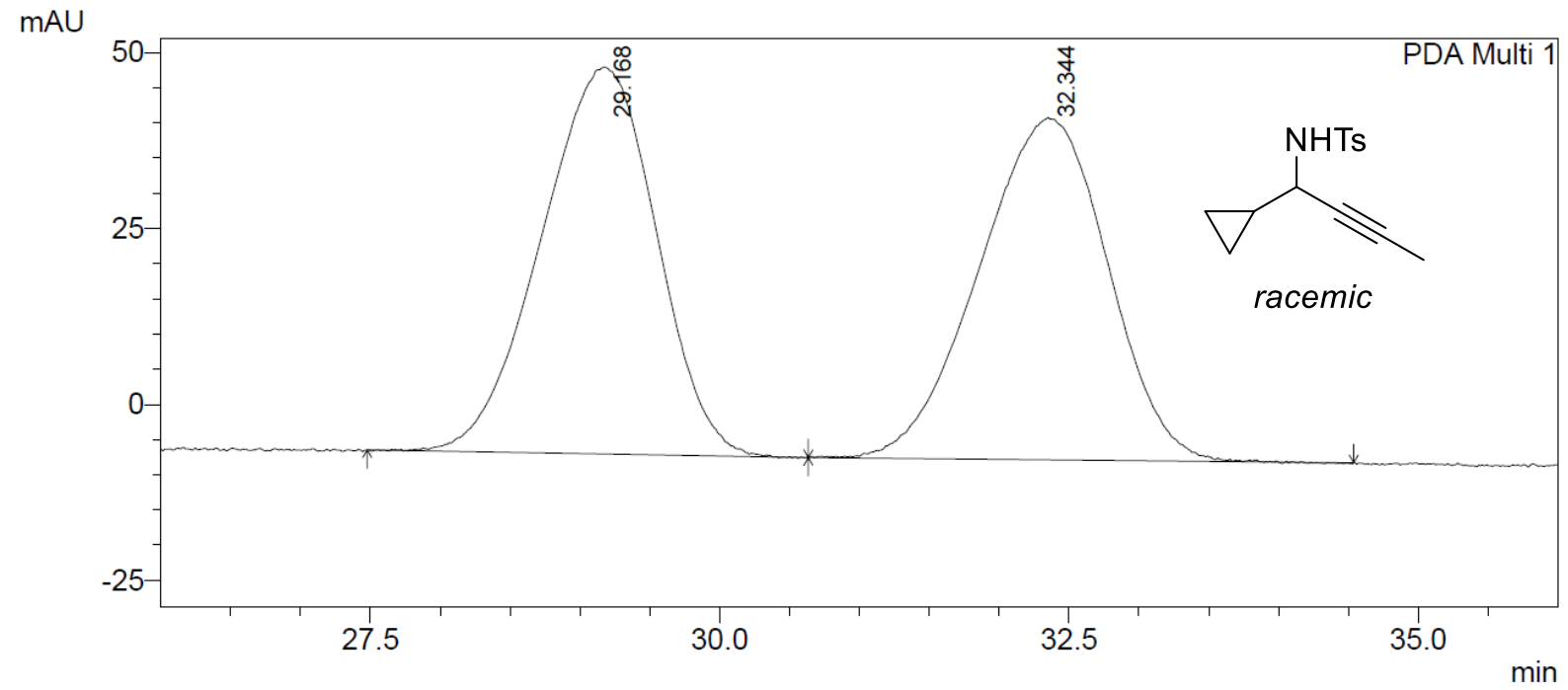

1 PDA Multi 1/200nm 4nm

PDA Ch1 200nm 4nm

\begin{tabular}{|r|r|r|r|r|r|}
\hline \multicolumn{1}{|c|}{ Peak\# } & Ret. Time & \multicolumn{1}{c|}{ Area } & \multicolumn{1}{c|}{ Height } & Area \% & \multicolumn{1}{c|}{ Height \% } \\
\hline 1 & 29.168 & 3148419 & 54995 & 50.296 & 53.070 \\
\hline 2 & 32.344 & 3111368 & 48632 & 49.704 & 46.930 \\
\hline Total & & 6259787 & 103627 & 100.000 & 100.000 \\
\hline
\end{tabular}

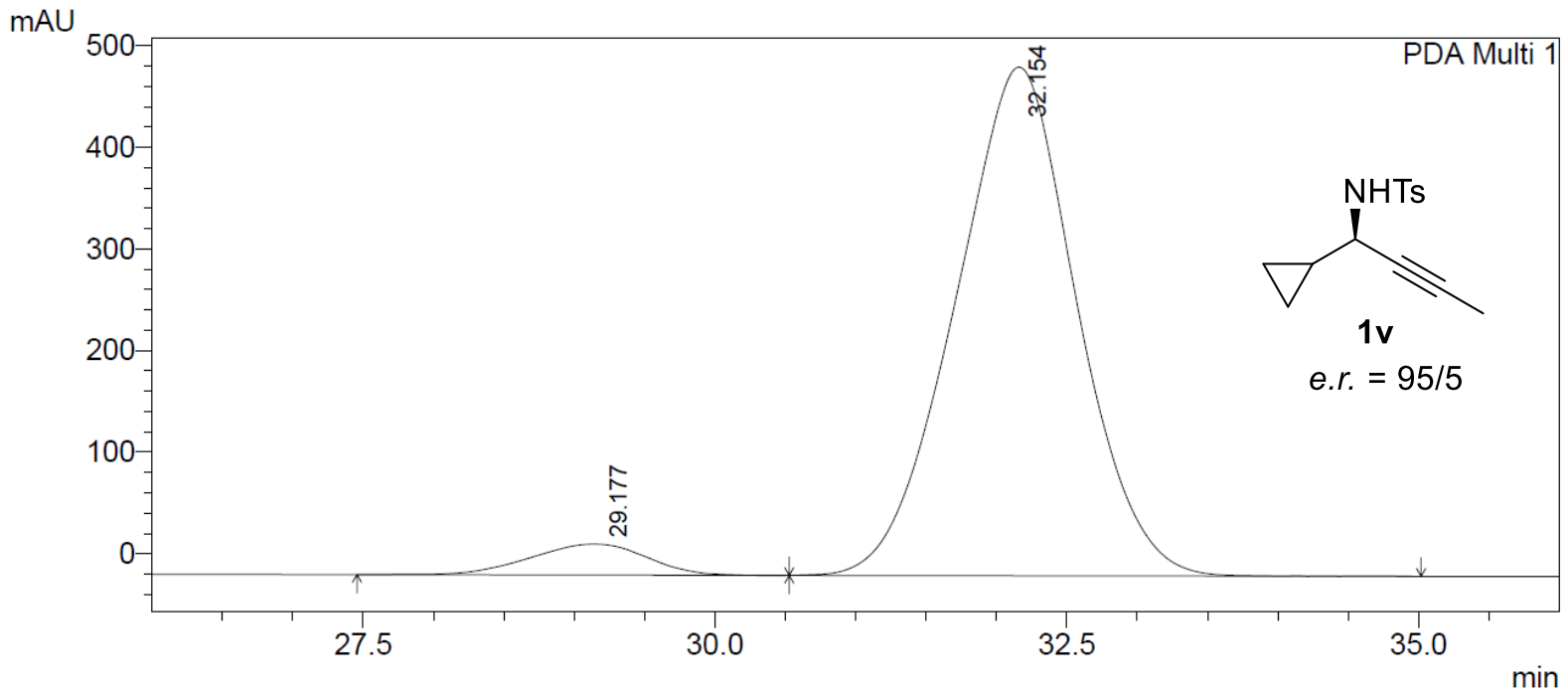

1 PDA Multi 1/200nm 4nm

PeakTable

PDA Ch1 200nm 4nm

\begin{tabular}{|r|r|r|r|r|r|}
\hline Peak\# & Ret. Time & \multicolumn{1}{|c|}{ Area } & \multicolumn{1}{|c|}{ Height } & Area \% & \multicolumn{1}{c|}{ Height \% } \\
\hline 1 & 29.177 & 1738763 & 30620 & 5.501 & 5.763 \\
\hline 2 & 32.154 & 29869655 & 500723 & 94.499 & 94.237 \\
\hline Total & & 31608418 & 531342 & 100.000 & 100.000 \\
\hline
\end{tabular}




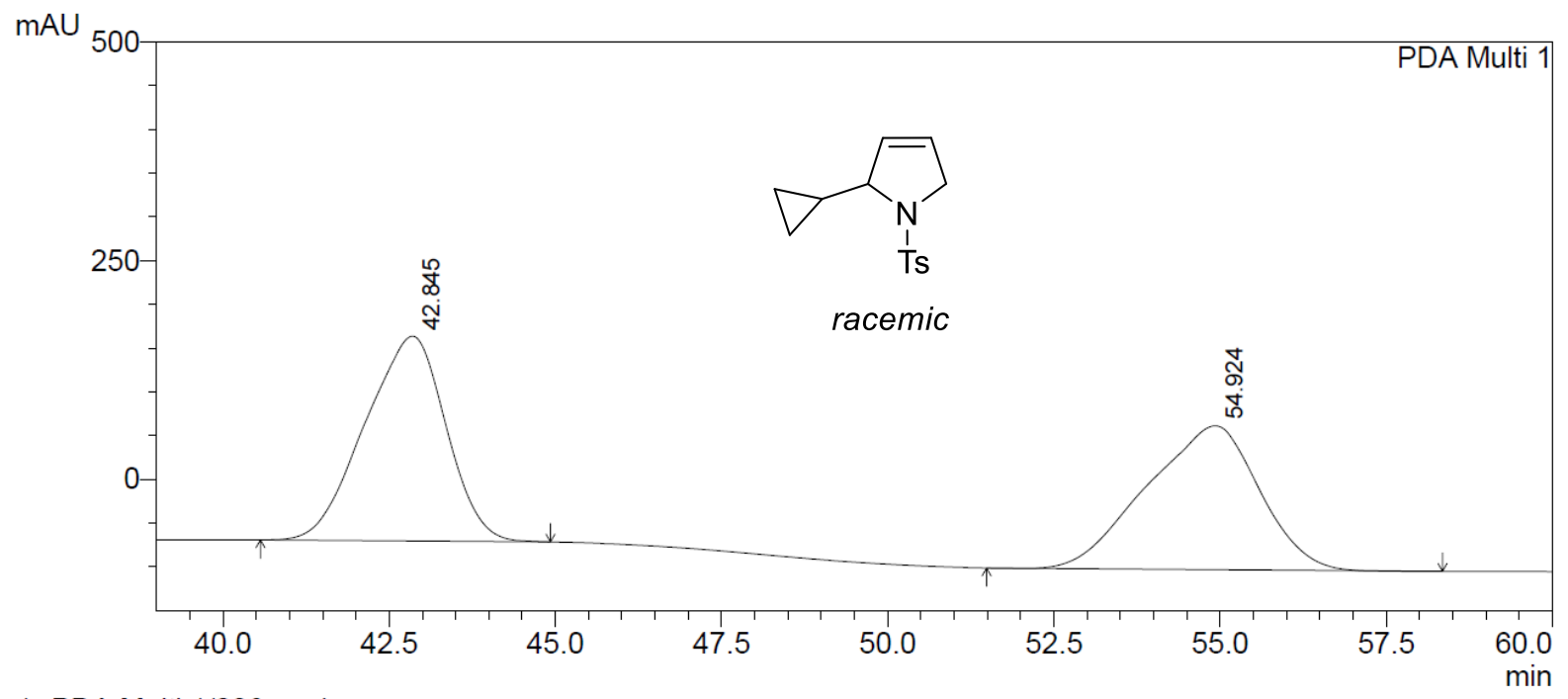

1 PDA Multi 1/206nm 4nm

PDA Ch1 206nm 4nm

PeakTable

\begin{tabular}{|r|r|r|r|r|r|}
\hline Peak\# & Ret. Time & \multicolumn{1}{|c|}{ Area } & Height & Area \% & \multicolumn{1}{c|}{ Height \% } \\
\hline 1 & 42.845 & 19880414 & 234081 & 50.662 & 58.717 \\
\hline 2 & 54.924 & 19360926 & 164576 & 49.338 & 41.283 \\
\hline Total & & 39241340 & 398657 & 100.000 & 100.000 \\
\hline
\end{tabular}

$m A U$

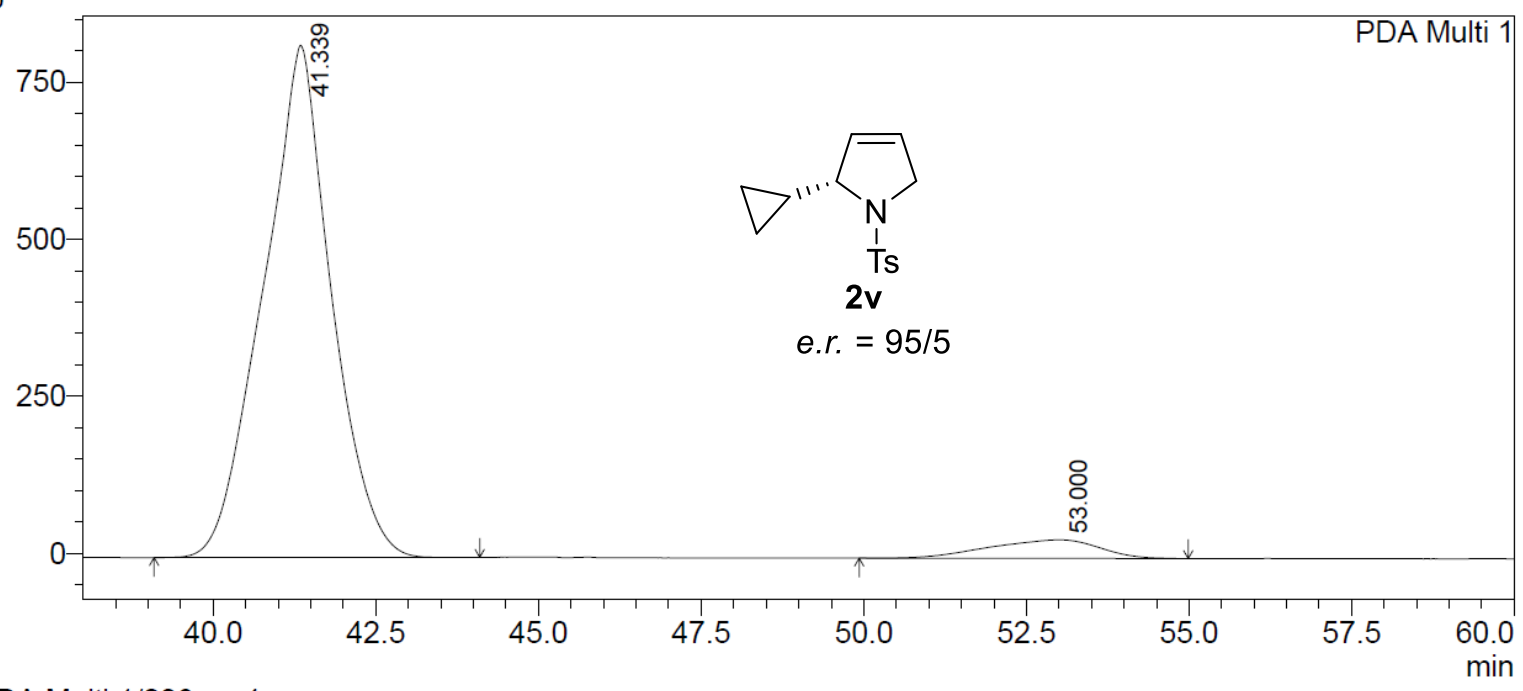

1 PDA Multi 1/206nm 4nm

PDA Ch1 206nm 4nm

PeakTable

\begin{tabular}{|r|r|r|r|r|r|}
\hline \multicolumn{1}{|c|}{ Peak\# } & Ret. Time & \multicolumn{1}{c|}{ Area } & \multicolumn{1}{c|}{ Height } & \multicolumn{1}{c|}{ Area \% } & \multicolumn{1}{c|}{ Height \% } \\
\hline 1 & 41.339 & 59072150 & 814980 & 94.478 & 96.508 \\
\hline 2 & 53.000 & 3452829 & 29489 & 5.522 & 3.492 \\
\hline Total & & 62524979 & 844469 & 100.000 & 100.000 \\
\hline
\end{tabular}




\begin{tabular}{|lr|}
\hline \multicolumn{3}{|c|}{ Parameters } \\
Title & \multicolumn{1}{c|}{ Value } \\
Spectrometer & cxp-3-77-2-H1-2 \\
\hline
\end{tabular}

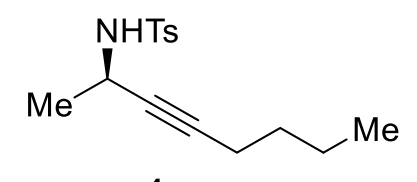

$1 a$

${ }^{1} \mathrm{H} \mathrm{NMR}, 600 \mathrm{MHz}, \mathrm{CDCl}_{3}$

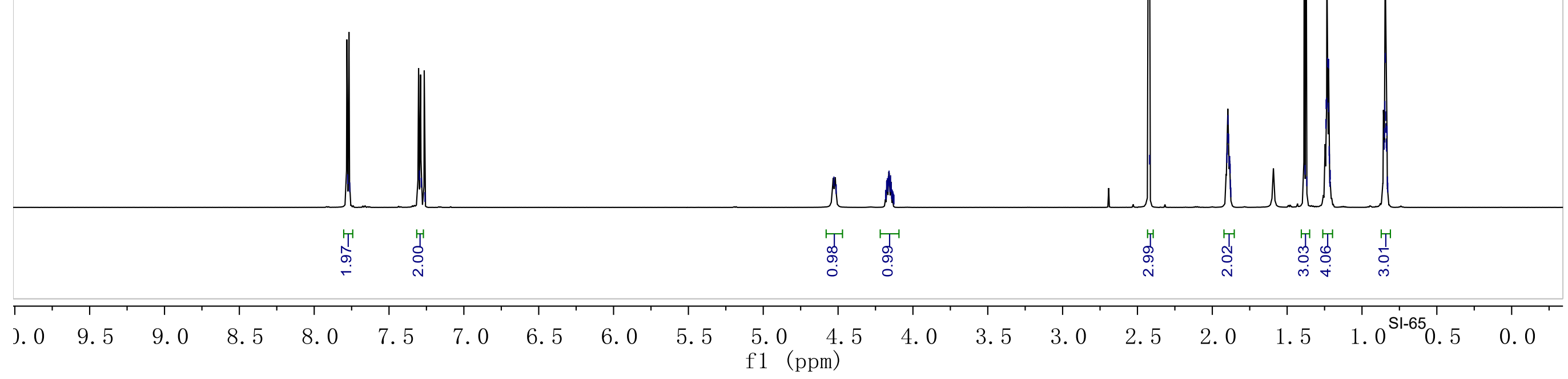




\begin{tabular}{|lr|}
\hline \multicolumn{3}{|c|}{ Parameters } \\
Title & \multicolumn{1}{c|}{ Value } \\
Spectrometer & cxp-3-135-2-p-H1 \\
\hline
\end{tabular}

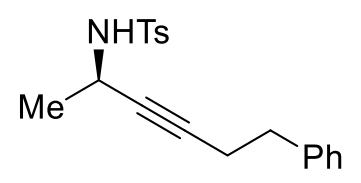

$1 b$

${ }^{1} \mathrm{H} \mathrm{NMR}, 600 \mathrm{MHz}, \mathrm{CDCl}_{3}$

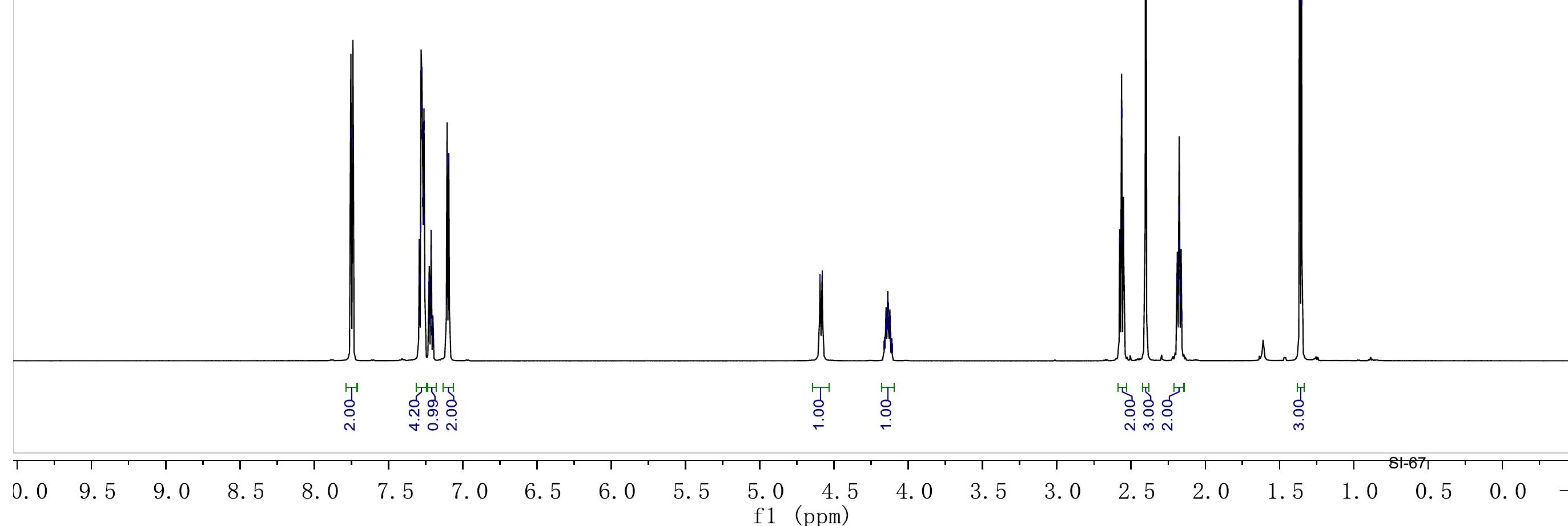




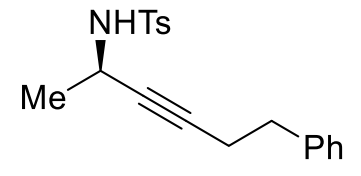

$1 b$

${ }^{13} \mathrm{C} \mathrm{NMR}, 101 \mathrm{MHz}, \mathrm{CDCl}_{3}$

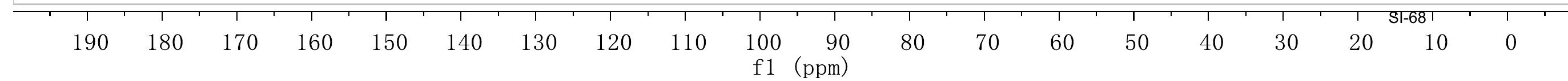




\begin{tabular}{|lr|}
\hline \multicolumn{2}{|c|}{ Parameters } \\
Title & \multicolumn{1}{c|}{ Value } \\
Spectrometer & cxp-3-149-2-p-H1 \\
\hline
\end{tabular}

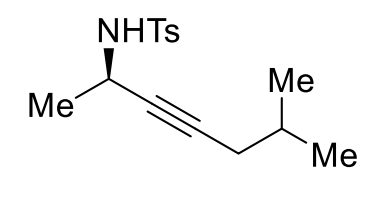

$1 c$

${ }^{1} \mathrm{H}$ NMR, $500 \mathrm{MHz}, \mathrm{CDCl}_{3}$

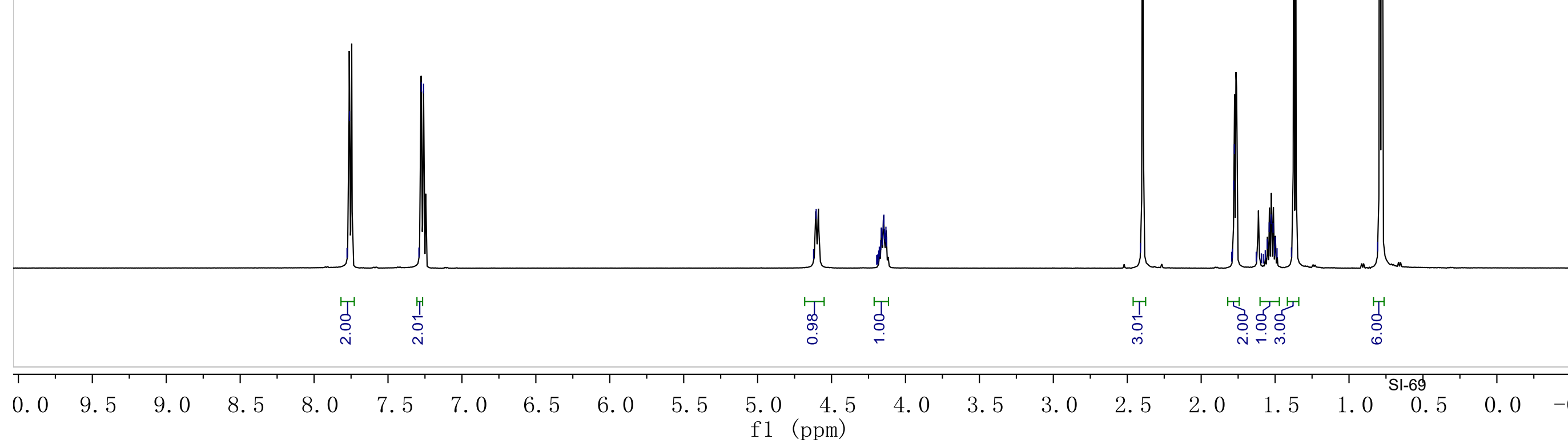




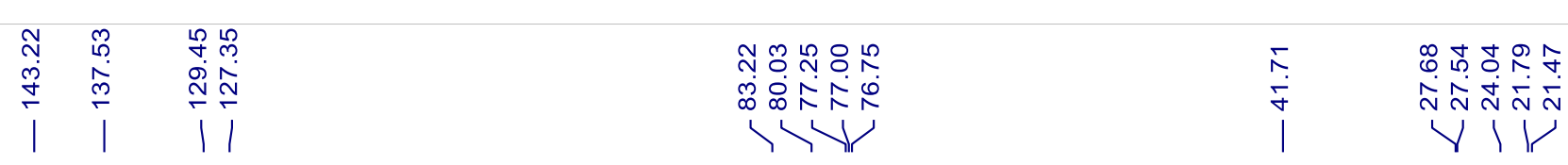

Parameter

Value

Title

cxp-3-149-2-p-C13

Spectrometer Frequency

125.70

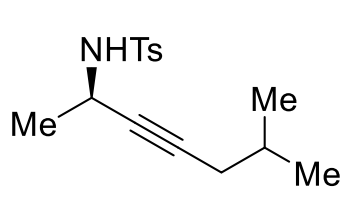

$1 \mathrm{c}$

${ }^{13} \mathrm{C} \mathrm{NMR,} 126 \mathrm{MHz}, \mathrm{CDCl}_{3}$

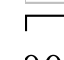

190

180

170

160

150

140

130

120

110

$\begin{array}{rr}100 & 90 \\ \mathrm{f} 1 & (\mathrm{ppm})\end{array}$




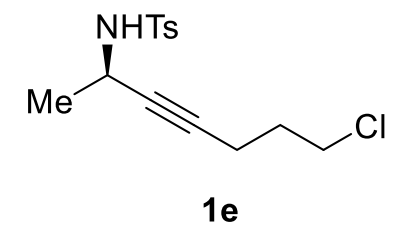

${ }^{1} \mathrm{H} \mathrm{NMR}, 500 \mathrm{MHz}, \mathrm{CDCl}_{3}$

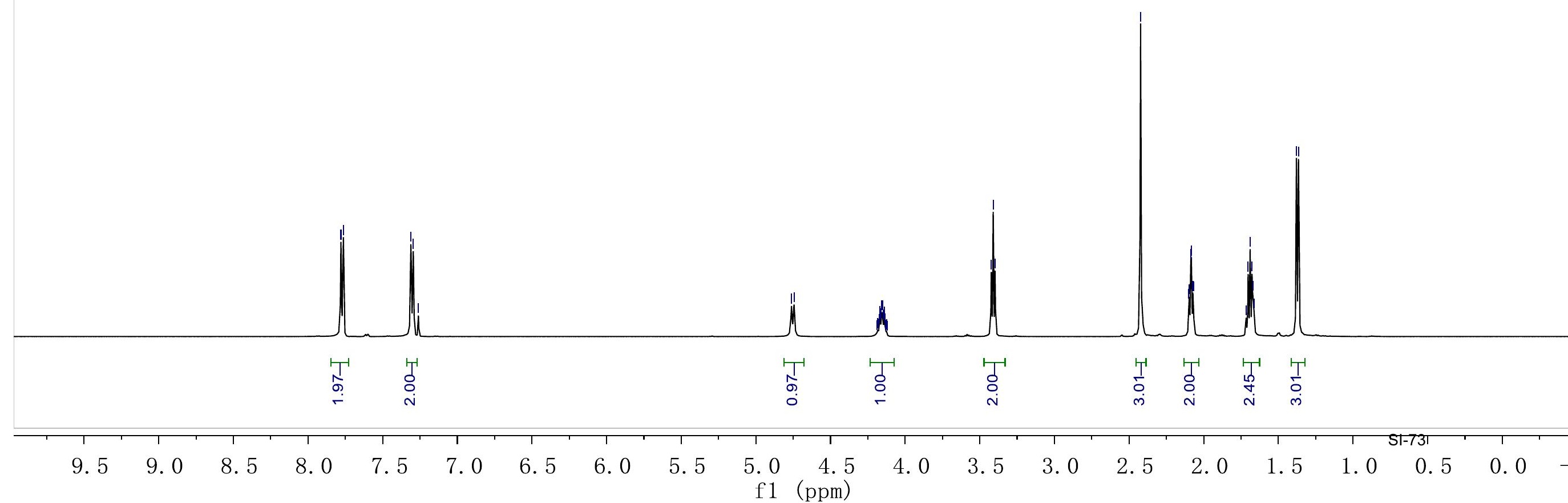



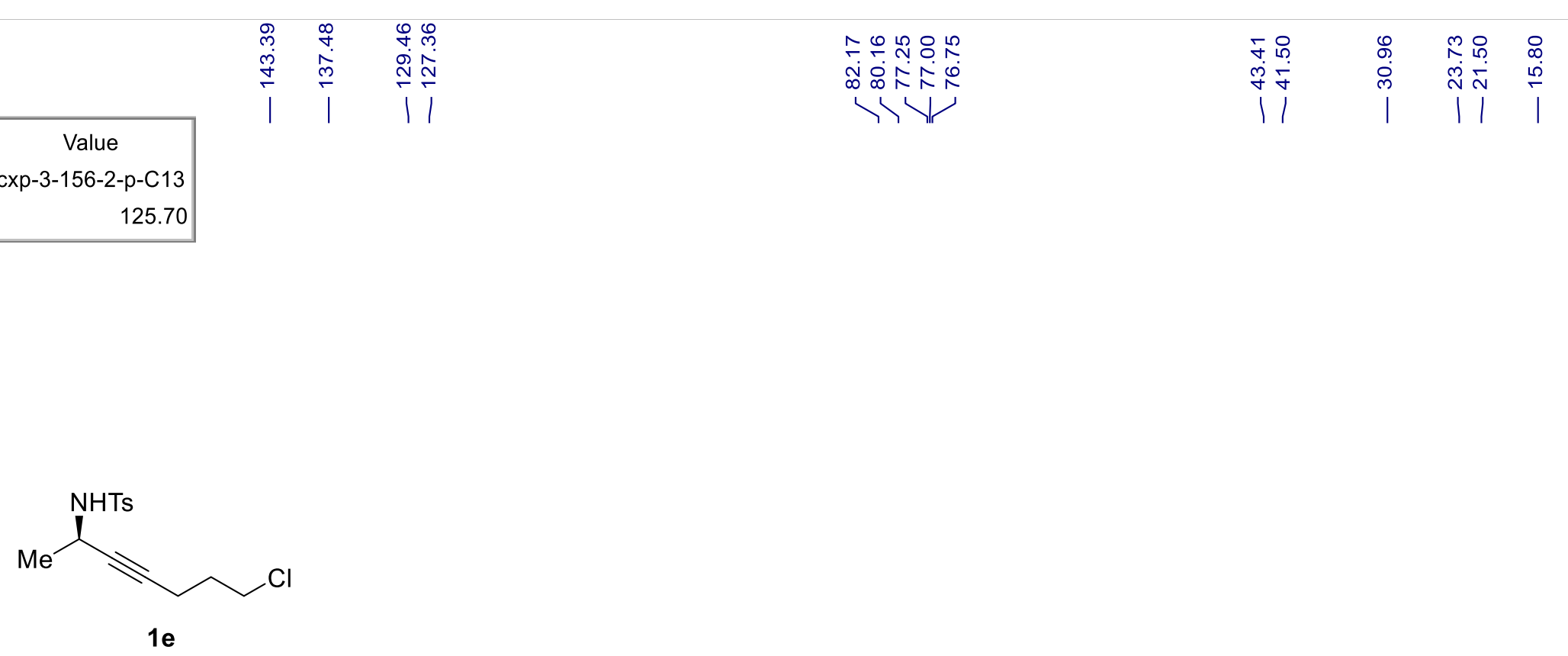

${ }^{13} \mathrm{C} \mathrm{NMR}, 126 \mathrm{MHz}, \mathrm{CDCl}_{3}$

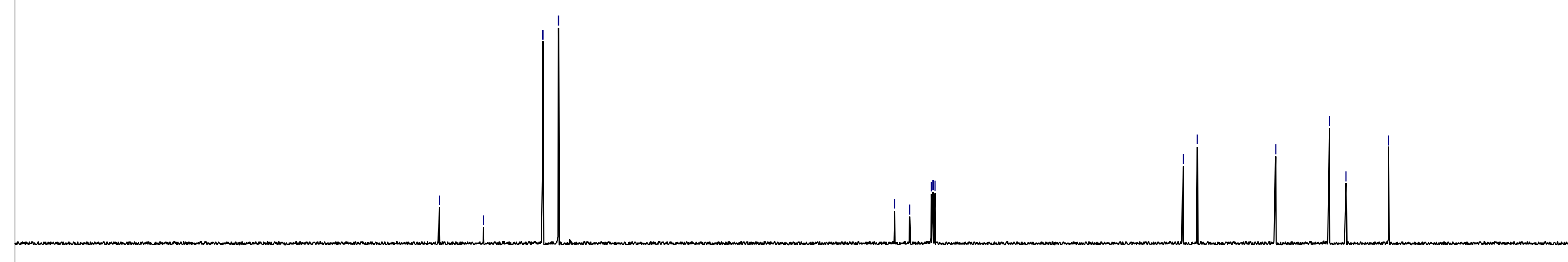

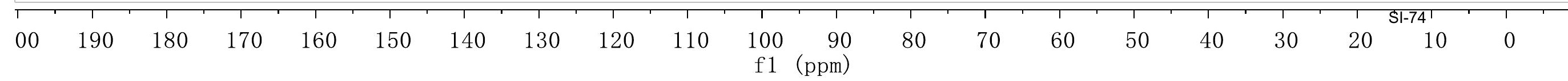




\begin{tabular}{|lrr|}
\hline \multicolumn{3}{|c|}{ Parameters } \\
& Parameter & \multicolumn{1}{c|}{ Value } \\
Title & & cxp-3-190-2-p-H1 \\
Spectrometer Frequency & 599.64 \\
\hline
\end{tabular}

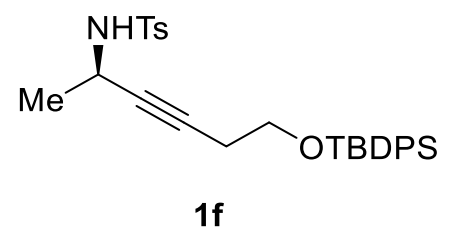

${ }^{1} \mathrm{H} \mathrm{NMR}, 600 \mathrm{MHz}, \mathrm{CDCl}_{3}$

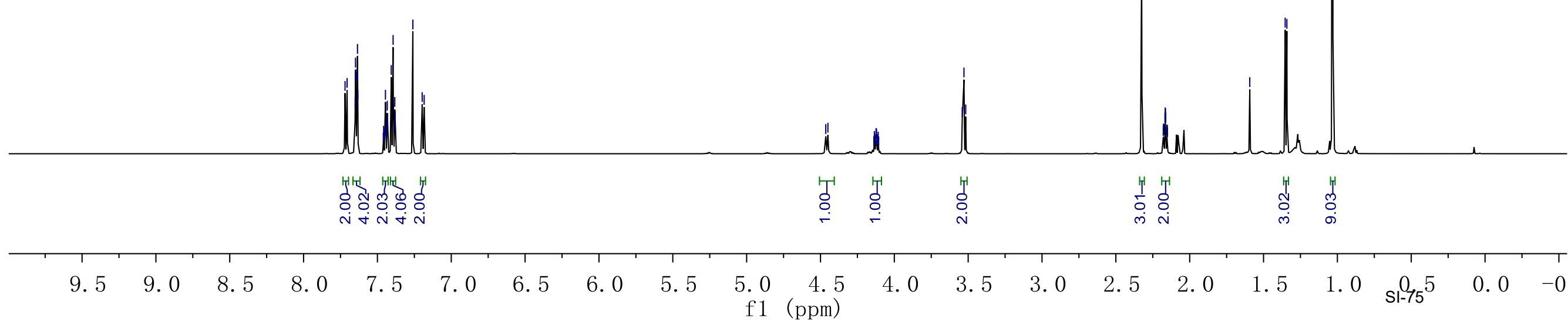


Spectrometer Frequency 100.53

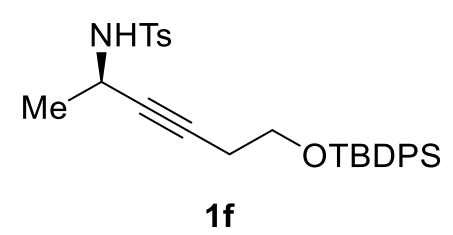

${ }^{13} \mathrm{C}$ NMR, $101 \mathrm{MHz}, \mathrm{CDCl}_{3}$

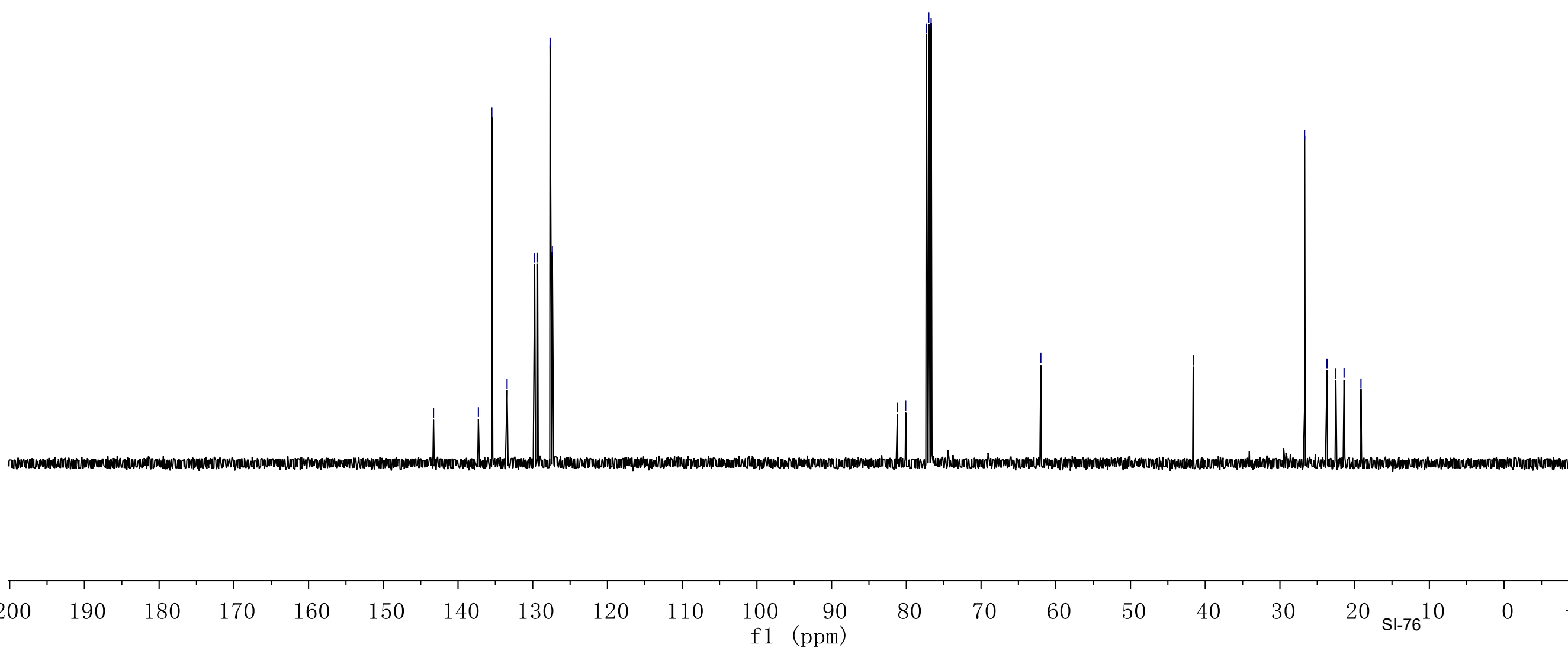




\begin{tabular}{|lr|}
\hline \multicolumn{2}{|c|}{ Parameters } \\
Parameter & \multicolumn{1}{c|}{ Value } \\
Title & cxp-4-134-p-3-C13 \\
Solvent & cdc13 \\
Spectrometer Frequency & 150.79 \\
\hline
\end{tabular}

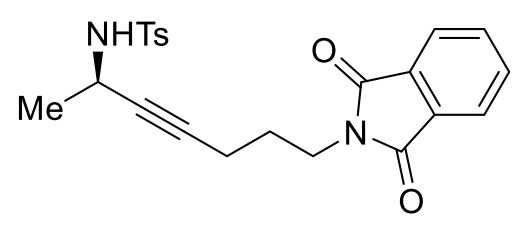

$1 \mathrm{~g}$

${ }^{13} \mathrm{C} \mathrm{NMR}, 151 \mathrm{MHz}, \mathrm{CDCl}_{3}$

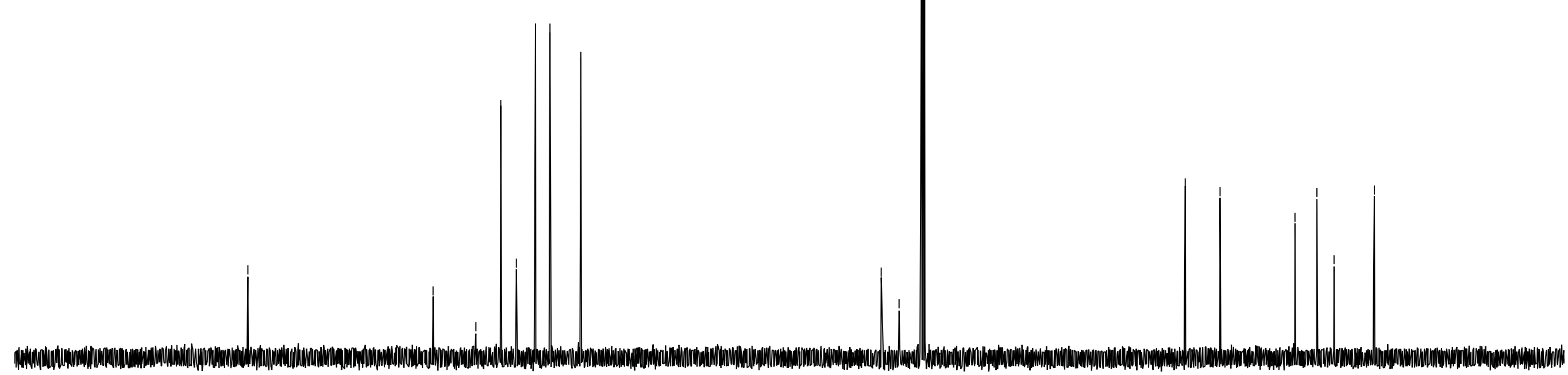




\begin{tabular}{|lr|}
\hline \multicolumn{3}{|c|}{ Parameters } \\
Parameter & \multicolumn{1}{c|}{ Value } \\
Title & cxp-3-210-p-H1 \\
Spectrometer Frequency & 599.64 \\
\hline
\end{tabular}

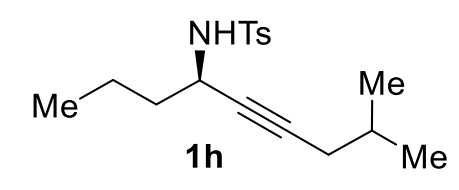

${ }^{1} \mathrm{H}$ NMR, $600 \mathrm{MHz}, \mathrm{CDCl}_{3}$

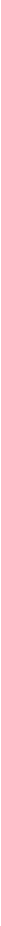




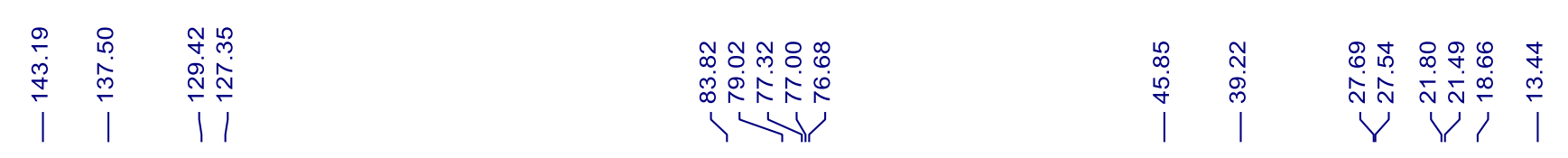

Title cxp-3-210-p-C13

Spectrometer Frequency $\quad 100.53$

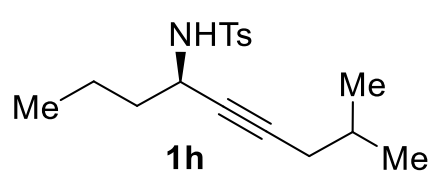

${ }^{13} \mathrm{C} \mathrm{NMR}, 101 \mathrm{MHz}, \mathrm{CDCl}_{3}$

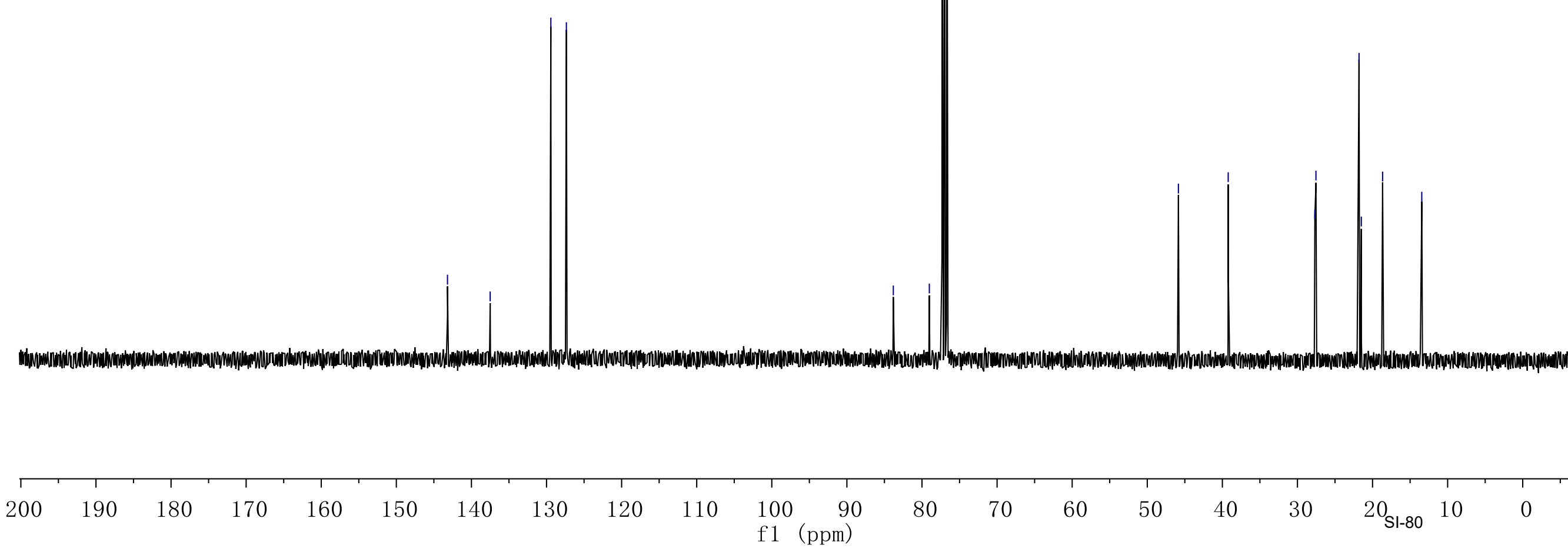




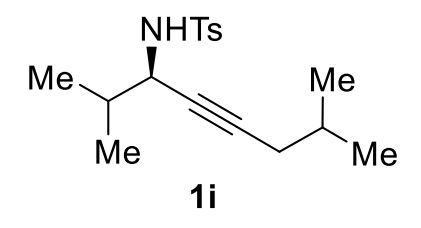

${ }^{1} \mathrm{H}$ NMR, $500 \mathrm{MHz}, \mathrm{CDCl}_{3}$

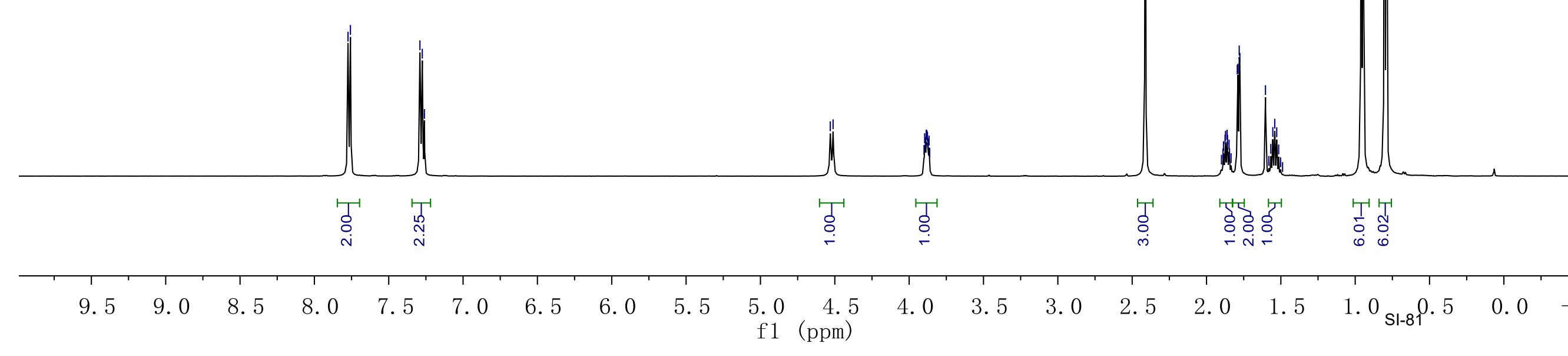




\section{Parameters \\ Parameter}

Title

Spectrometer Frequency

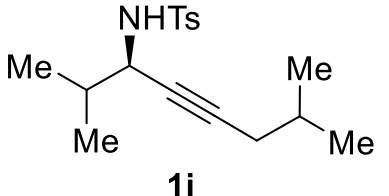

$1 \mathrm{i}$

${ }^{13} \mathrm{C} \mathrm{NMR,} 101 \mathrm{MHz}, \mathrm{CDCl}_{3}$

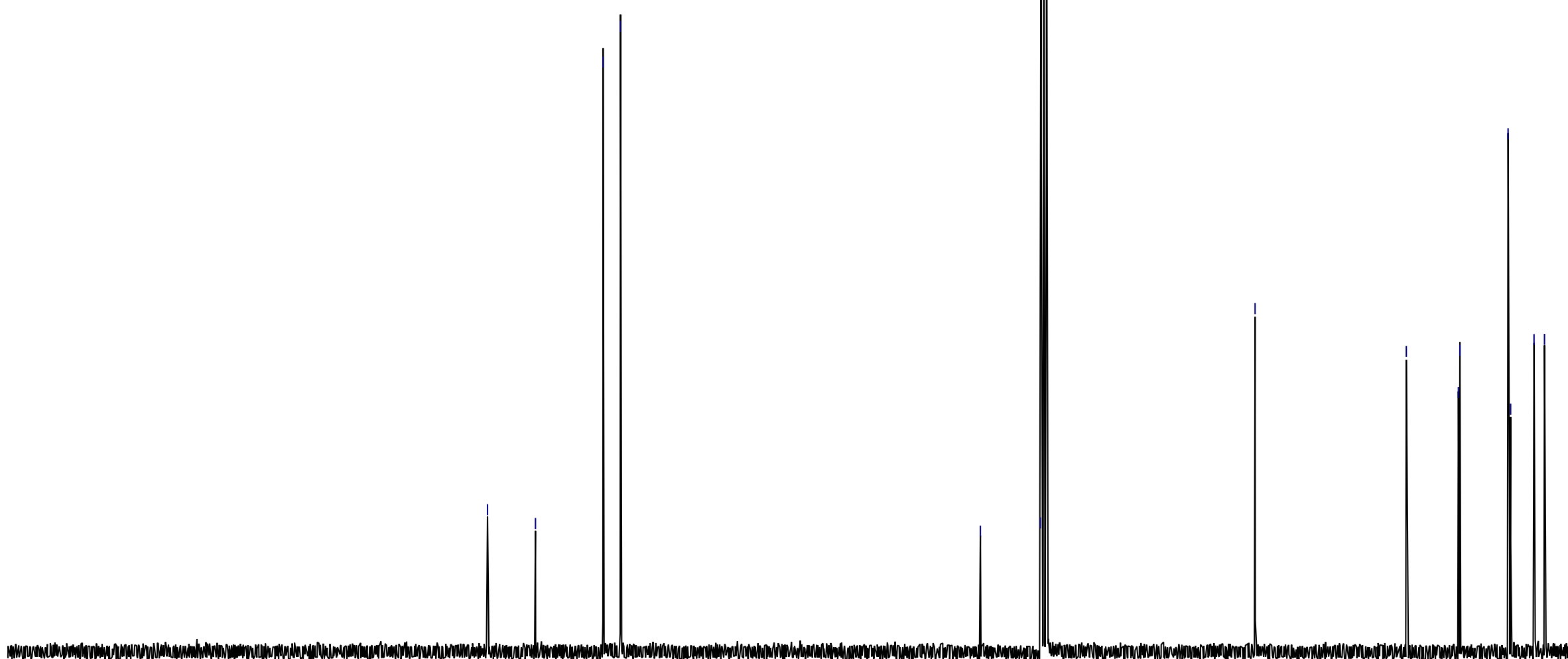

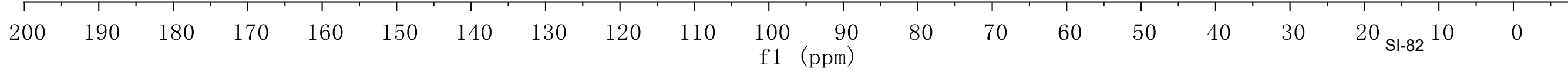




\begin{tabular}{|lr|}
\hline \multicolumn{3}{|c|}{ Parameters } \\
Title & \multicolumn{2}{c|}{ Value } \\
Spectrometer Frequency & cxp-3-207-2-p-H1 \\
\hline
\end{tabular}

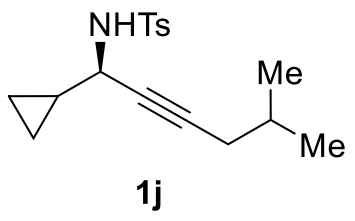

${ }^{1} \mathrm{H}$ NMR, $500 \mathrm{MHz}, \mathrm{CDCl}_{3}$

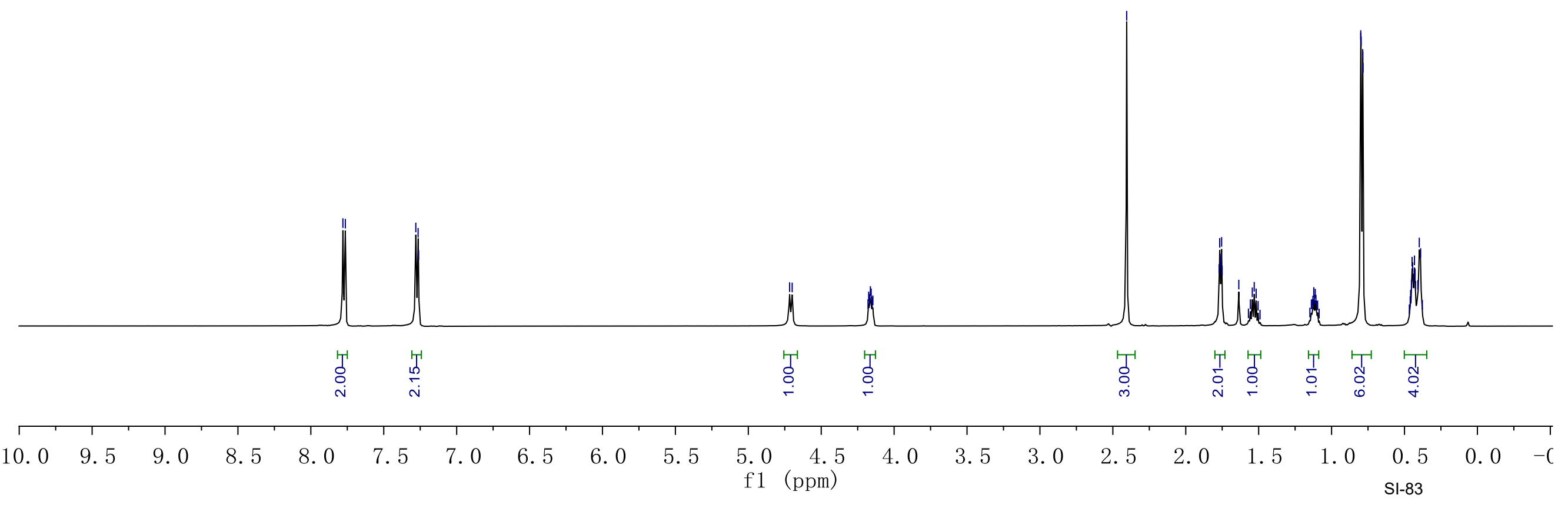




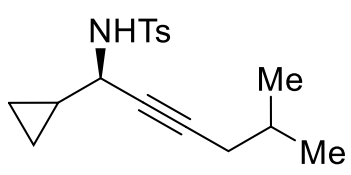

1j

${ }^{13} \mathrm{C} \mathrm{NMR}, 101 \mathrm{MHz}, \mathrm{CDCl}_{3}$

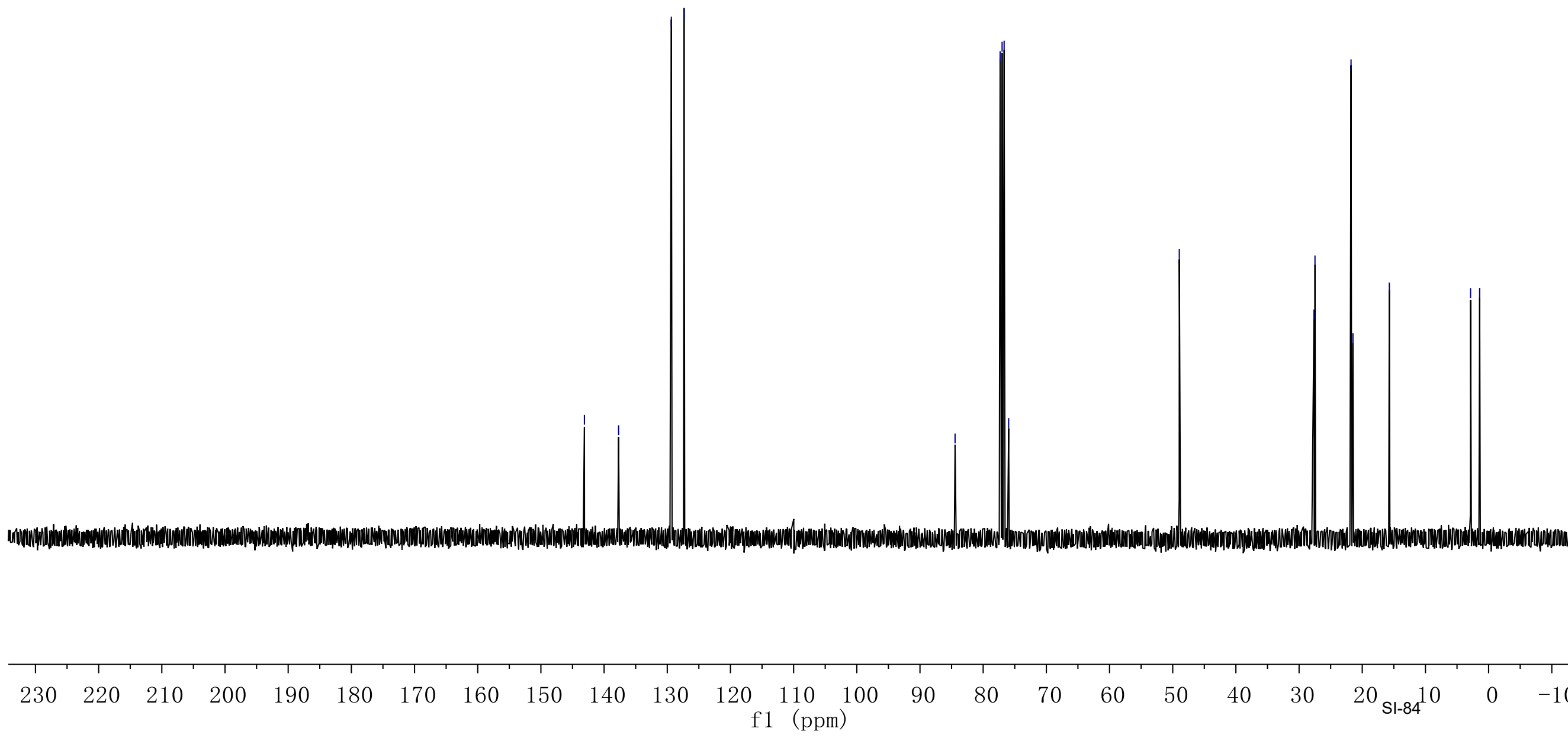




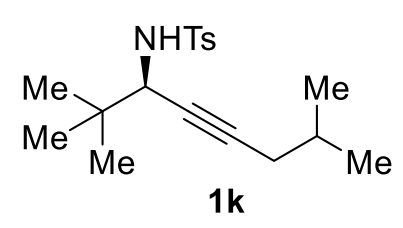

${ }^{1} \mathrm{H} \mathrm{NMR}, 600 \mathrm{MHz}, \mathrm{CDCl}_{3}$

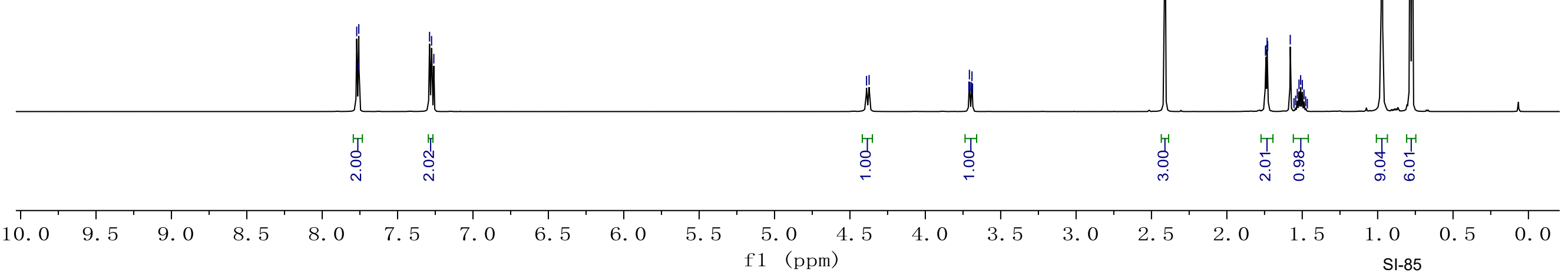




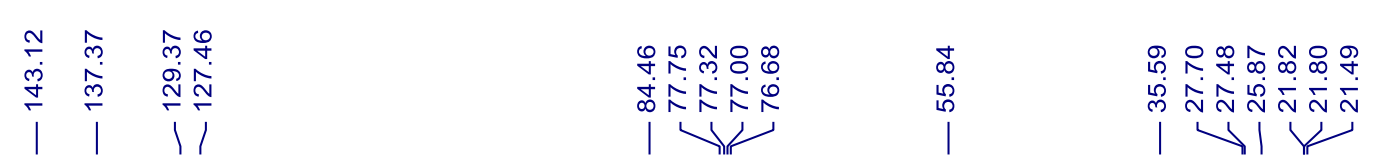

\begin{tabular}{|rr} 
Title $r$ cxp-3-234-2-p-C13 \\
Spectrometer Frequency & 100.53
\end{tabular}
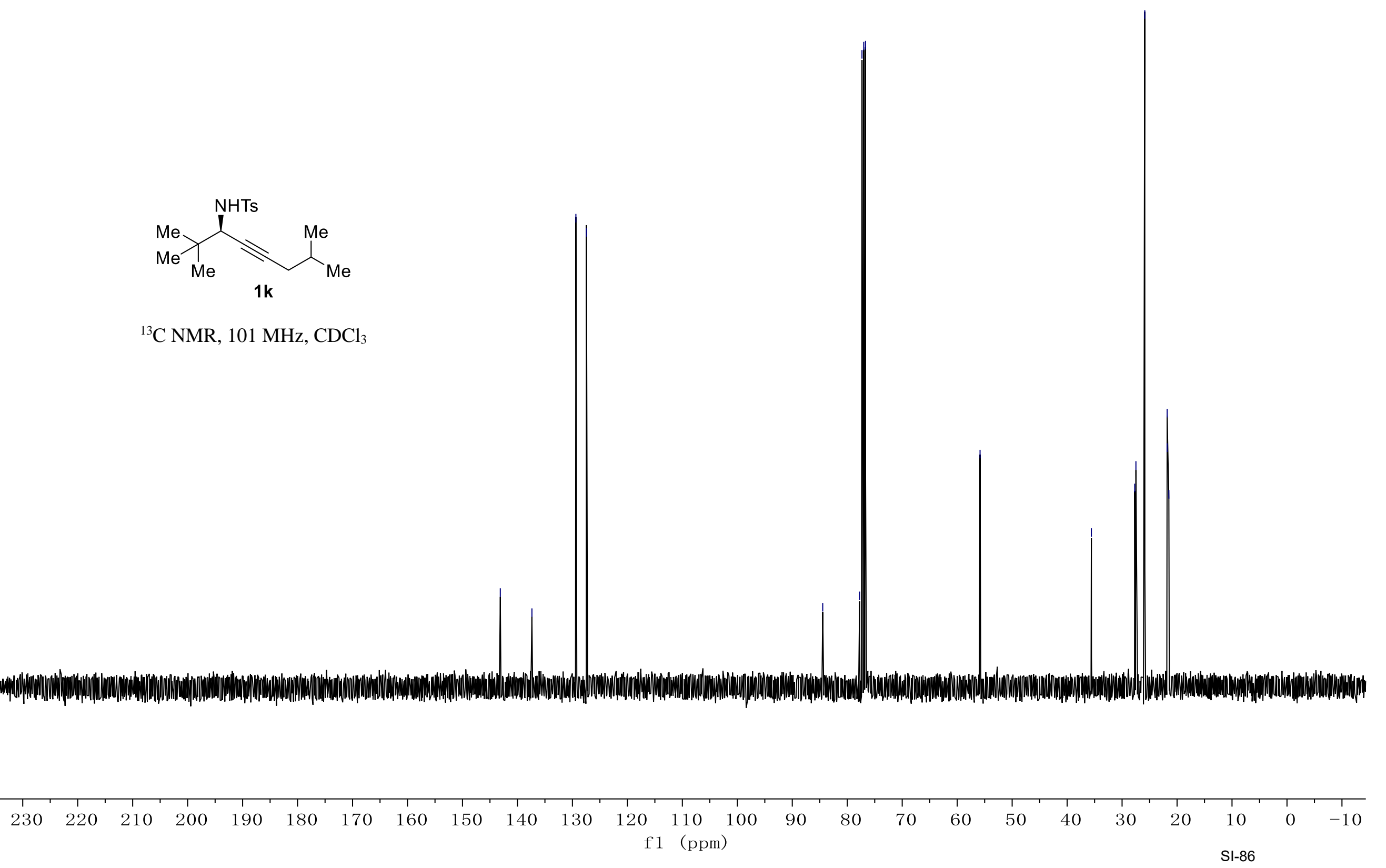


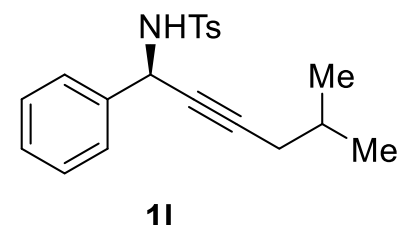

${ }^{1} \mathrm{H} \mathrm{NMR}, 600 \mathrm{MHz}, \mathrm{CDCl}_{3}$

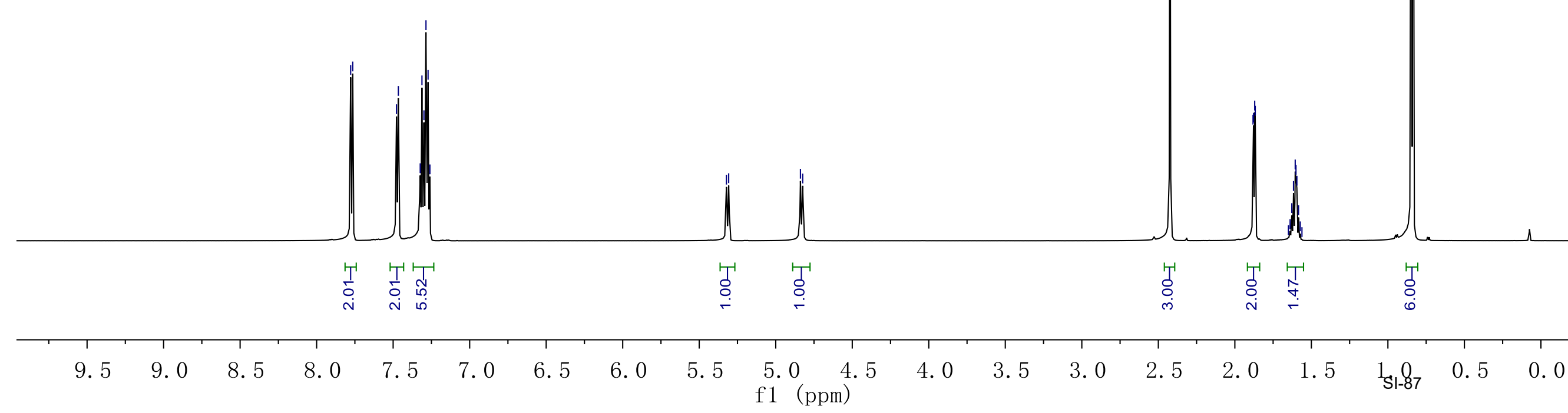


Spectrometer Frequency 100.53

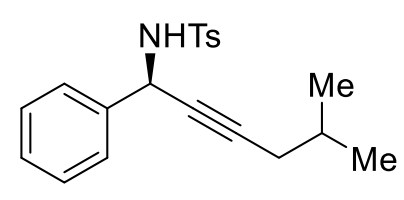

11

${ }^{13} \mathrm{C} \mathrm{NMR,} 101 \mathrm{MHz}, \mathrm{CDCl}_{3}$

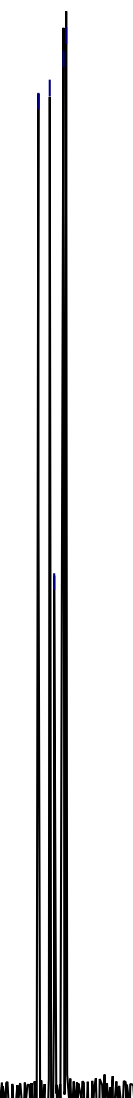




\begin{tabular}{|lr|}
\hline \multicolumn{3}{|c|}{ Parameters } \\
Title & \multicolumn{1}{c|}{ Value } \\
Spectrometer & cxp-3-225-2-p-H1 \\
\hline
\end{tabular}

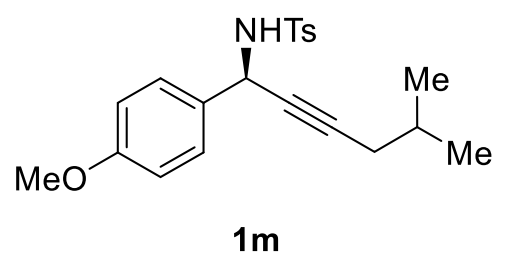

${ }^{1} \mathrm{H} \mathrm{NMR}, 600 \mathrm{MHz}, \mathrm{CDCl}_{3}$

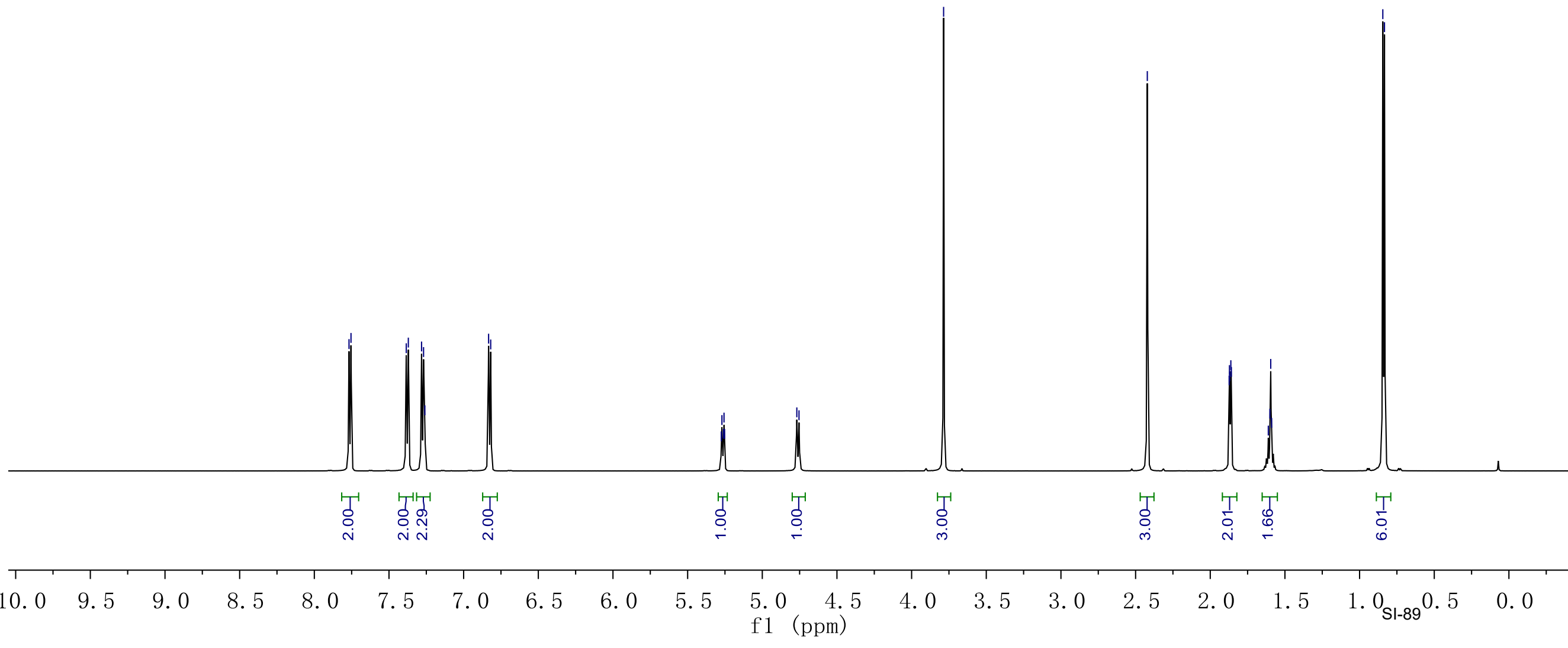




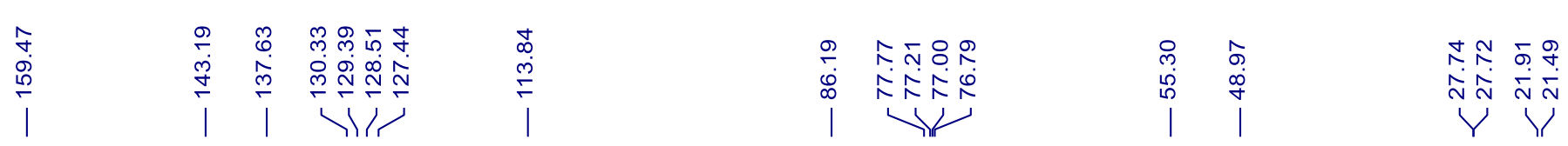

\begin{tabular}{|lrr|}
\hline \multicolumn{3}{|c|}{ Parameters } \\
& Parameter & \multicolumn{1}{c|}{ Value } \\
Title & cxp-3-225-2-p-C13 \\
Spectrometer Frequency & 150.79 \\
\hline
\end{tabular}

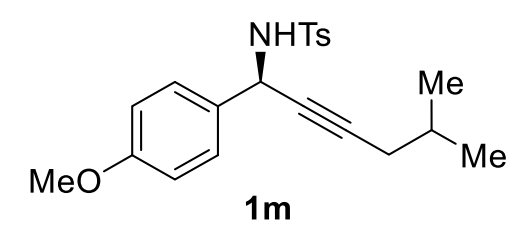

${ }^{13} \mathrm{C} \mathrm{NMR,} 151 \mathrm{MHz}, \mathrm{CDCl}_{3}$

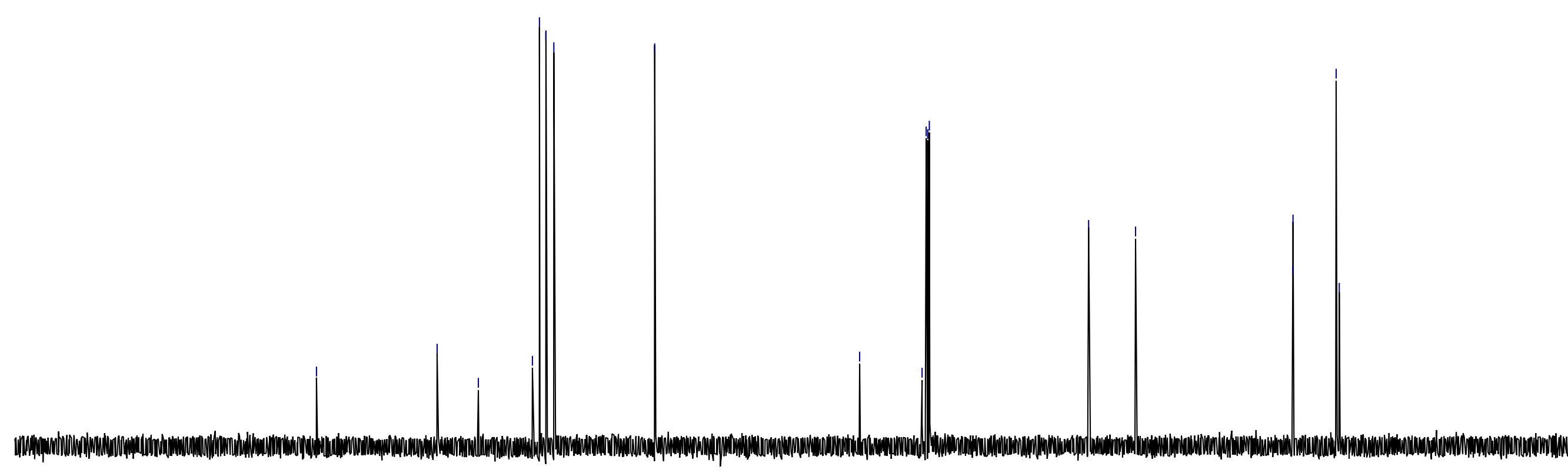

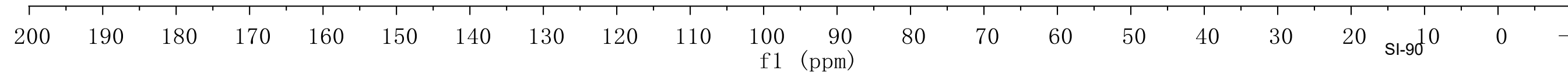




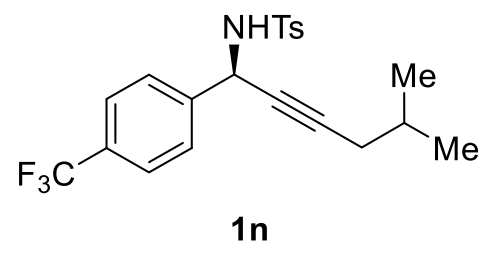

${ }^{1} \mathrm{H} \mathrm{NMR}, 600 \mathrm{MHz}, \mathrm{CDCl}_{3}$

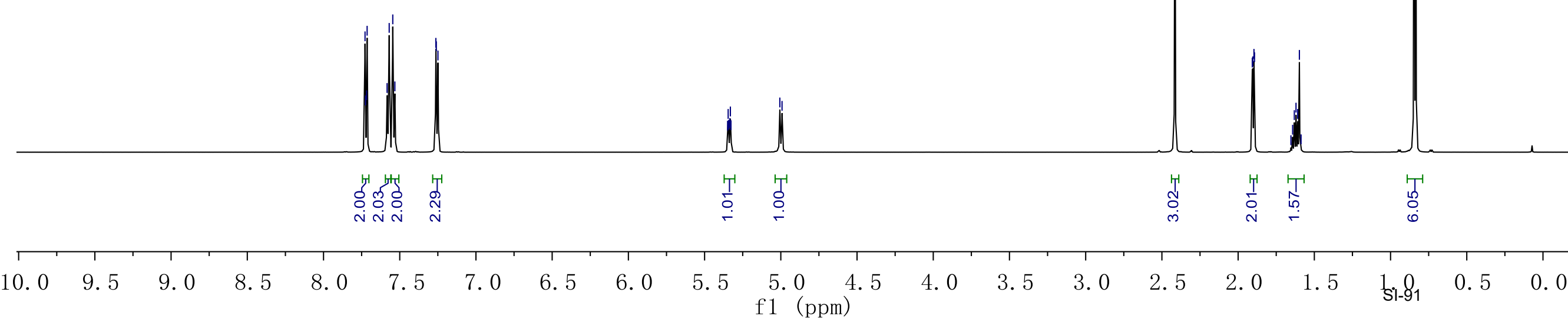


Spectrometer Frequency

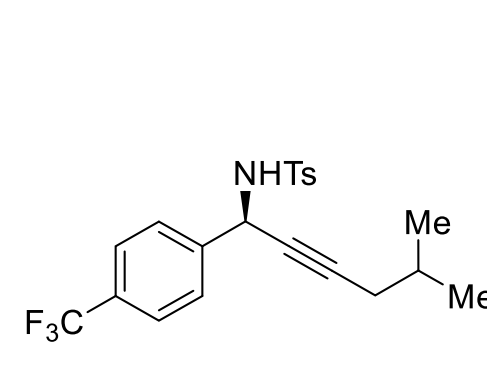

1n

${ }^{13} \mathrm{C}$ NMR, $101 \mathrm{MHz}, \mathrm{CDCl}_{3}$

\begin{tabular}{|c|c|c|c|c|c|c|c|c|c|c|c|c|c|c|c|c|c|c|}
\hline 190 & 180 & 170 & 16 & 150 & 140 & 130 & 120 & 110 & $\begin{array}{r}100 \\
\mathrm{f} 1\end{array}$ & $\begin{array}{c}90 \\
(\mathrm{ppm})\end{array}$ & 80 & 70 & 60 & 50 & 40 & 30 & 20 & $\mathrm{SI}-92^{10}$ \\
\hline
\end{tabular}




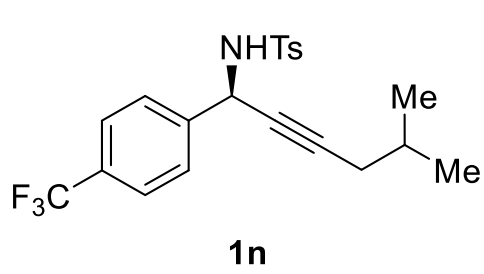

${ }^{19} \mathrm{~F} \mathrm{NMR,} 376 \mathrm{MHz}, \mathrm{CDCl}_{3}$

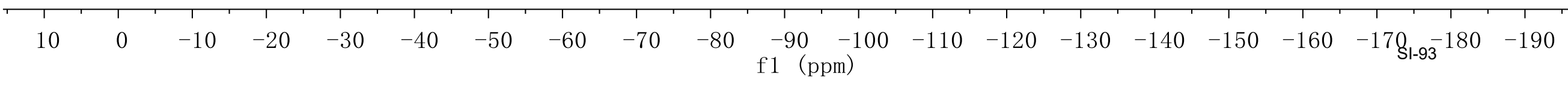




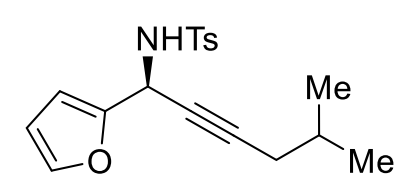

10

${ }^{1} \mathrm{H} \mathrm{NMR}, 600 \mathrm{MHz}, \mathrm{CDCl}_{3}$

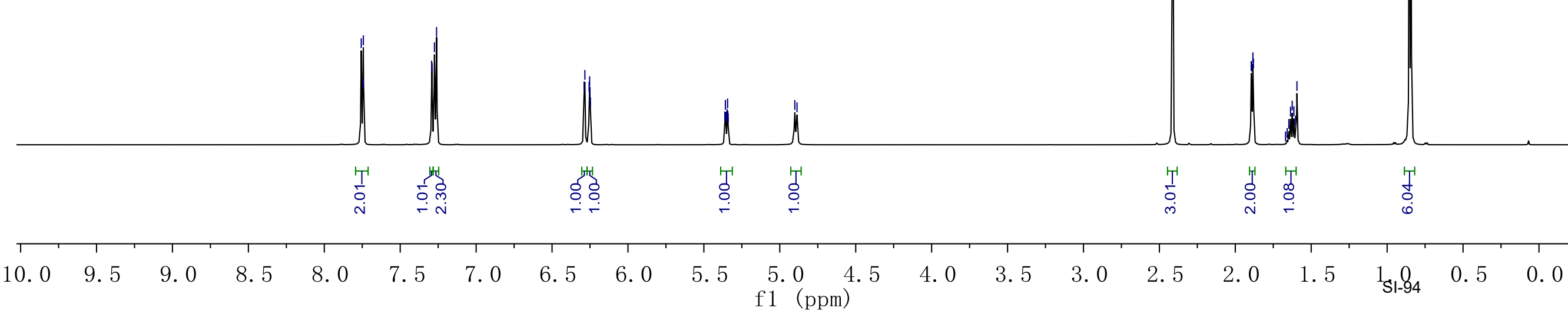




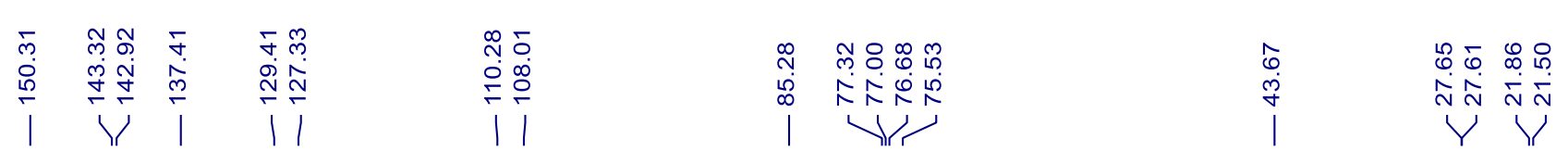

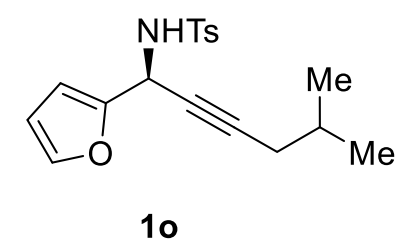

${ }^{13} \mathrm{C}$ NMR, $101 \mathrm{MHz}, \mathrm{CDCl}_{3}$

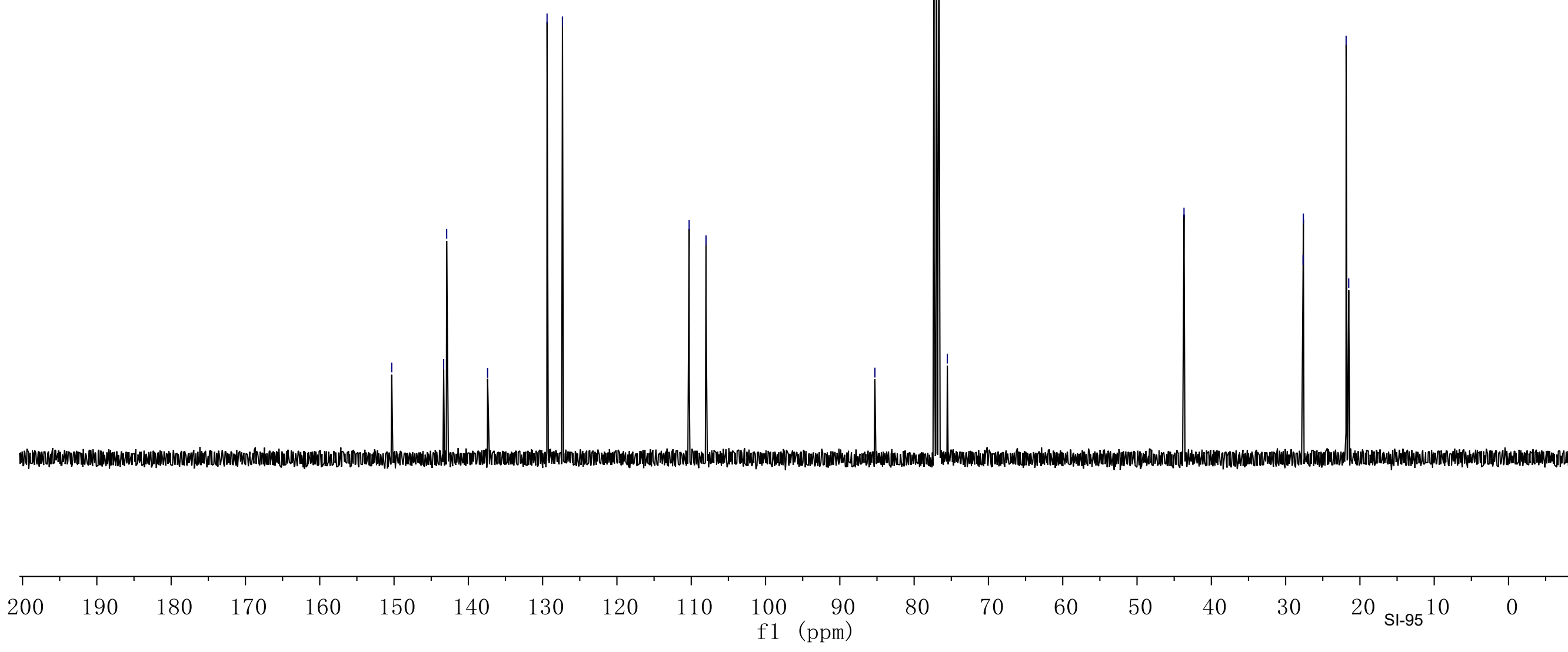




\begin{tabular}{|c|c|}
\hline \multicolumn{2}{|c|}{ Parameters } \\
\hline Parameter & Value \\
\hline Title & cxp-3-259-2-p-H1 \\
\hline Spectrometer Frequen & 599.64 \\
\hline
\end{tabular}

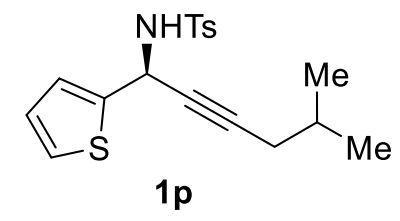

${ }^{1} \mathrm{H} \mathrm{NMR}, 600 \mathrm{MHz}, \mathrm{CDCl}_{3}$

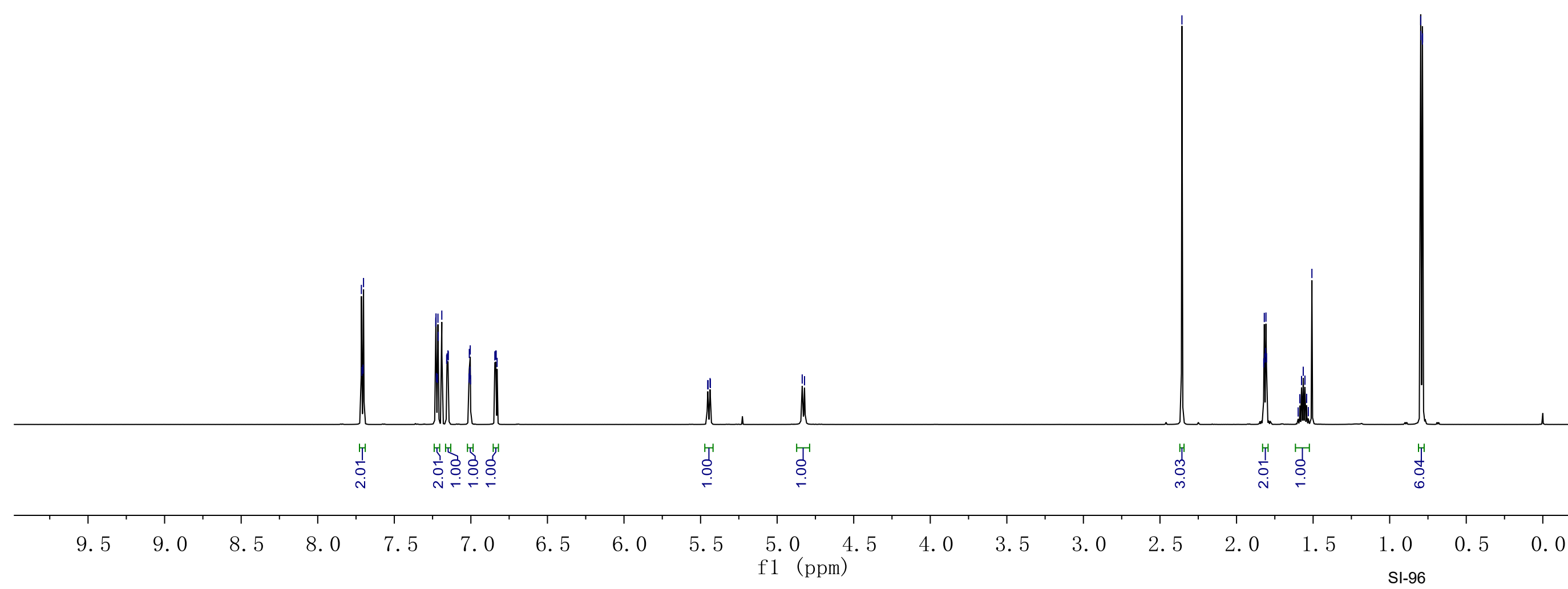




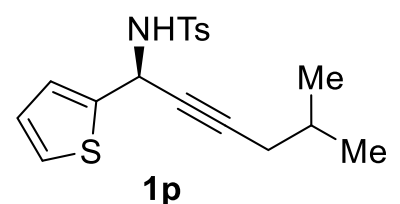

$1 p$

${ }^{13} \mathrm{C} \mathrm{NMR,} 101 \mathrm{MHz}, \mathrm{CDCl}_{3}$
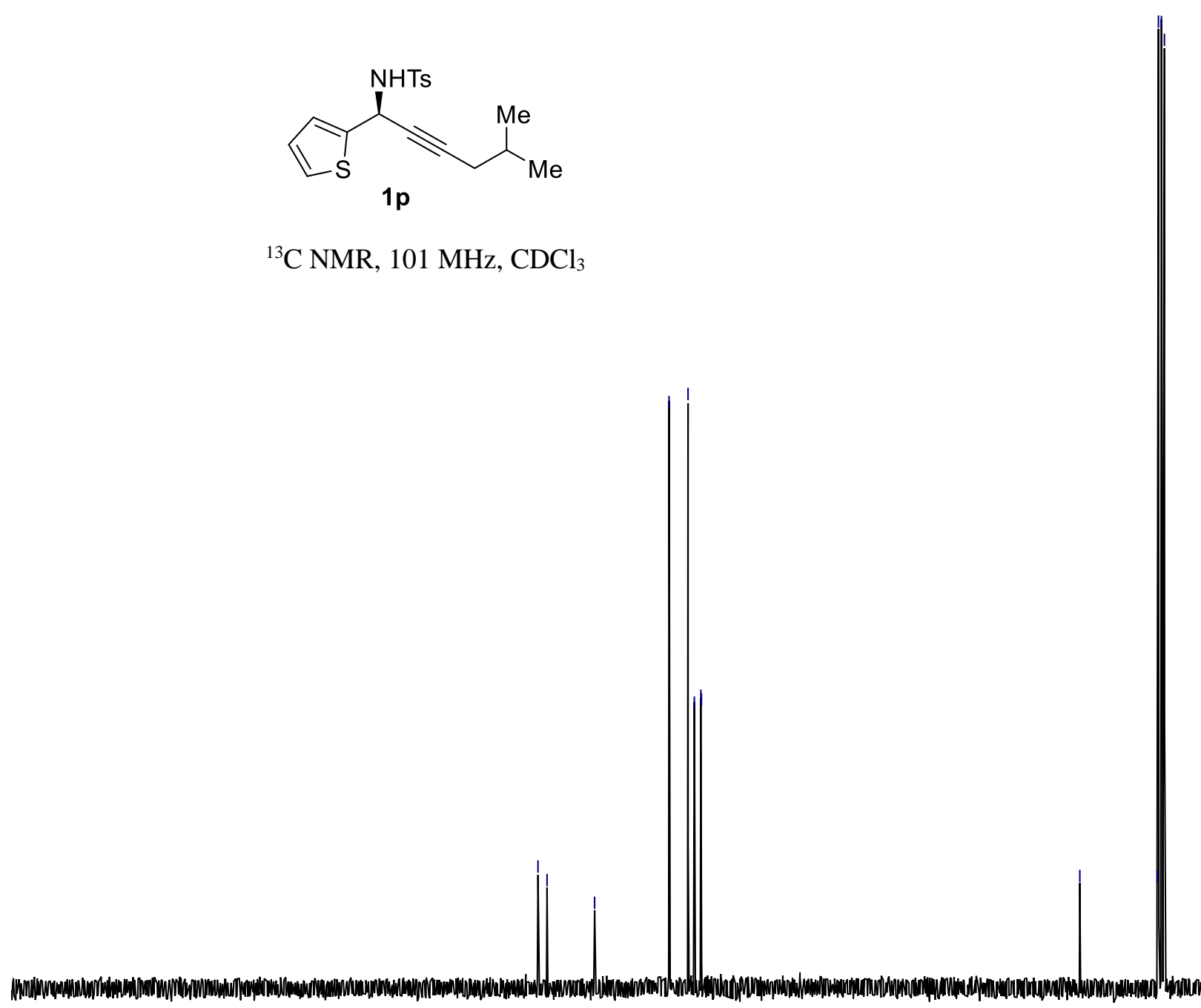

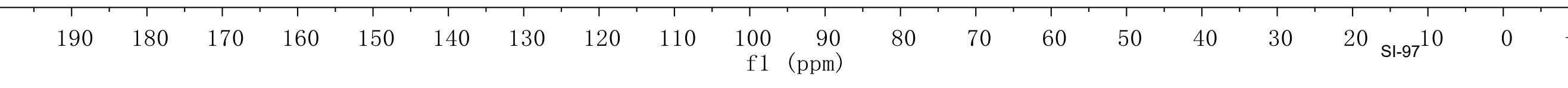




\begin{tabular}{|ll|}
\hline \multicolumn{1}{|c|}{ Parameter } & \multicolumn{1}{c|}{ Value } \\
1 Title & cxp-3-300-2-2 \\
2 Solvent & cdcl3 \\
3 Spectrometer Frequency & 599.64 \\
4 Nucleus & $1 \mathrm{H}$ \\
\hline
\end{tabular}

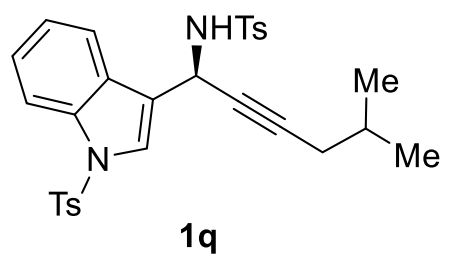

${ }^{1} \mathrm{H}$ NMR, $600 \mathrm{MHz}, \mathrm{CDCl}_{3}$

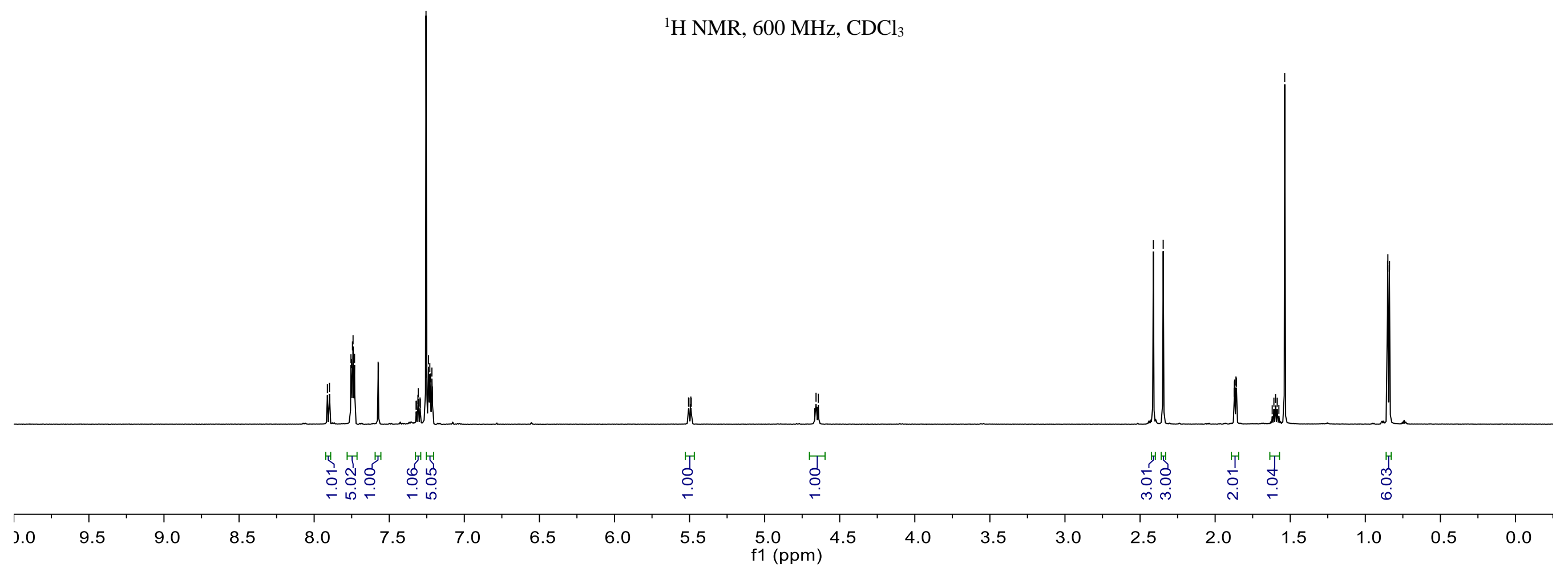


Parameters

Parameter

Title

Value

cxp-3-233-2-p-H1

Spectrometer Frequency $\quad 599.64$

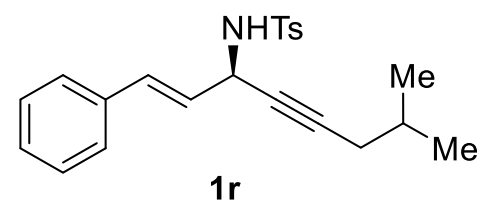

${ }^{1} \mathrm{H} \mathrm{NMR}, 600 \mathrm{MHz}, \mathrm{CDCl}_{3}$

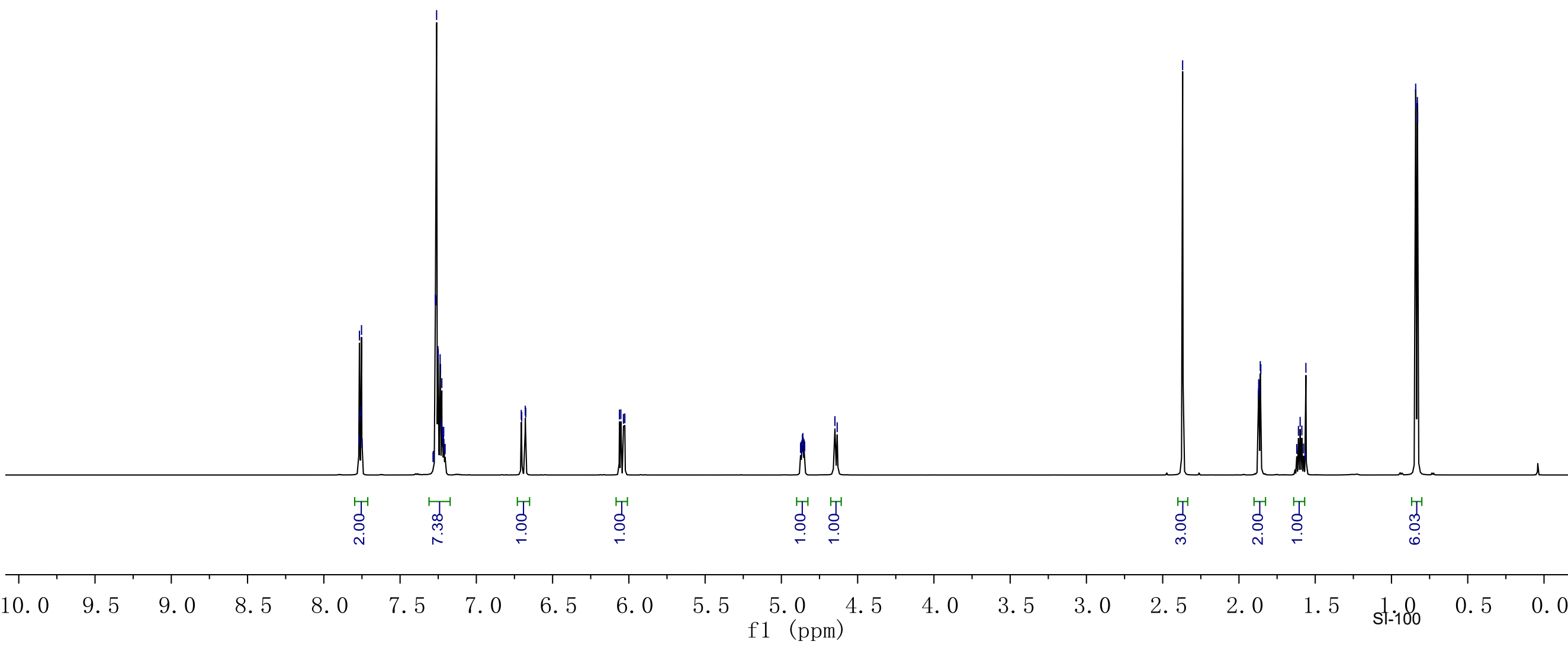


Spectrometer Frequency 100.53

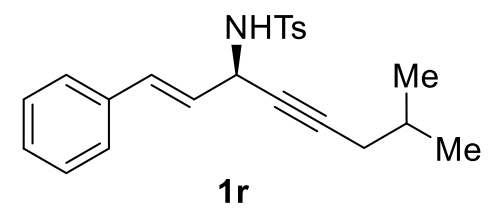

${ }^{13} \mathrm{C}$ NMR, $101 \mathrm{MHz}, \mathrm{CDCl}_{3}$

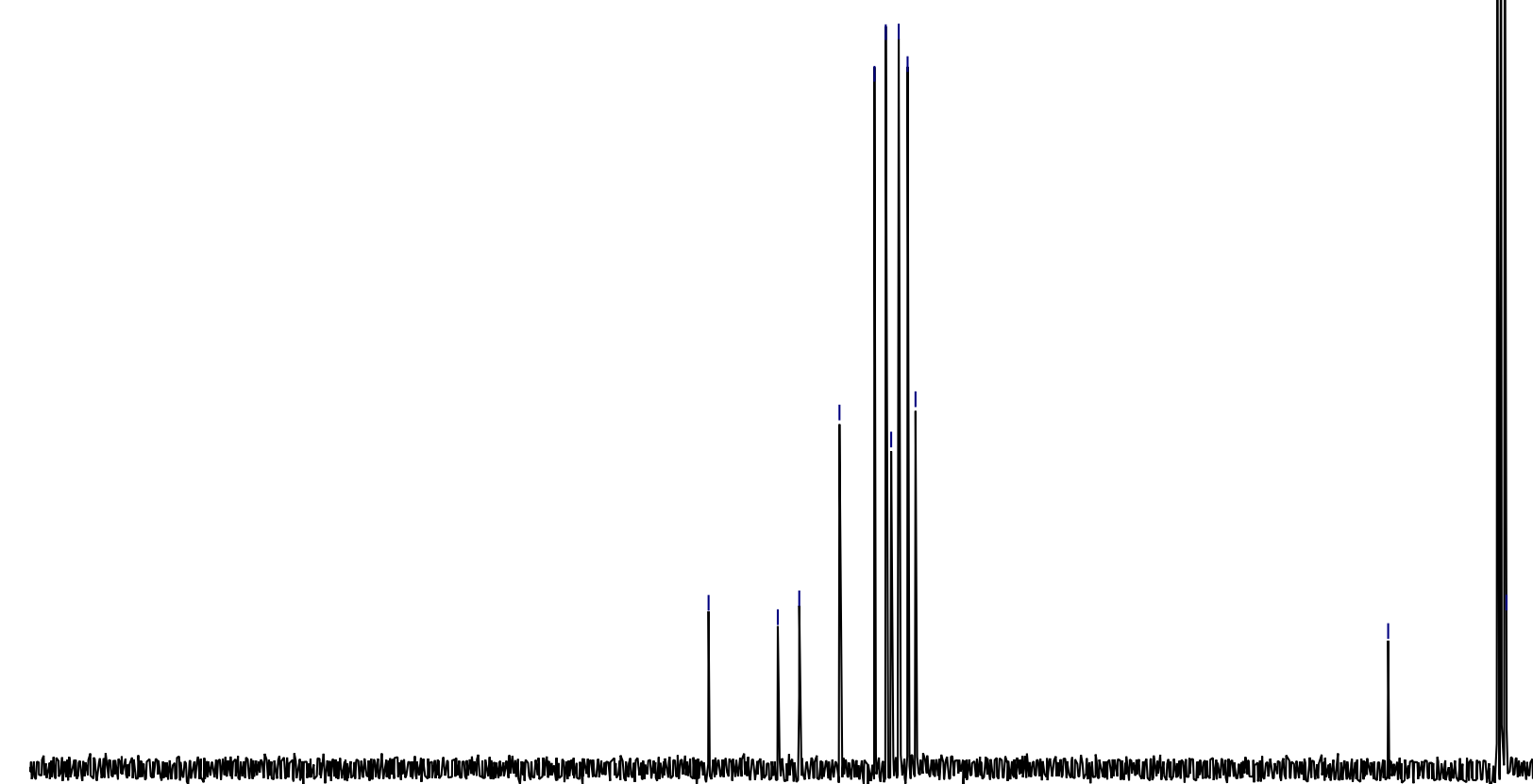

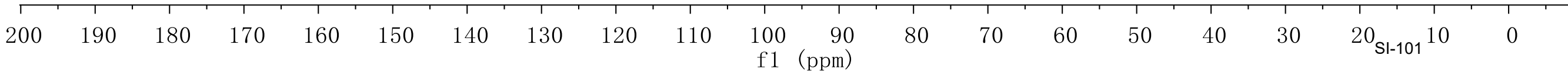




\begin{tabular}{|lr|}
\hline \multicolumn{2}{|c|}{ Parameters } \\
\multicolumn{3}{|c|}{ Parameter } & \multicolumn{1}{c|}{ Value } \\
Title & cxp-4-146-p-2-H1 \\
Solvent & cdc13 \\
Spectrometer Frequency & 399.78 \\
\hline
\end{tabular}

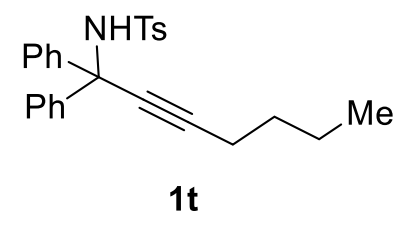

${ }^{1} \mathrm{H} \mathrm{NMR}, 400 \mathrm{MHz}, \mathrm{CDCl}_{3}$

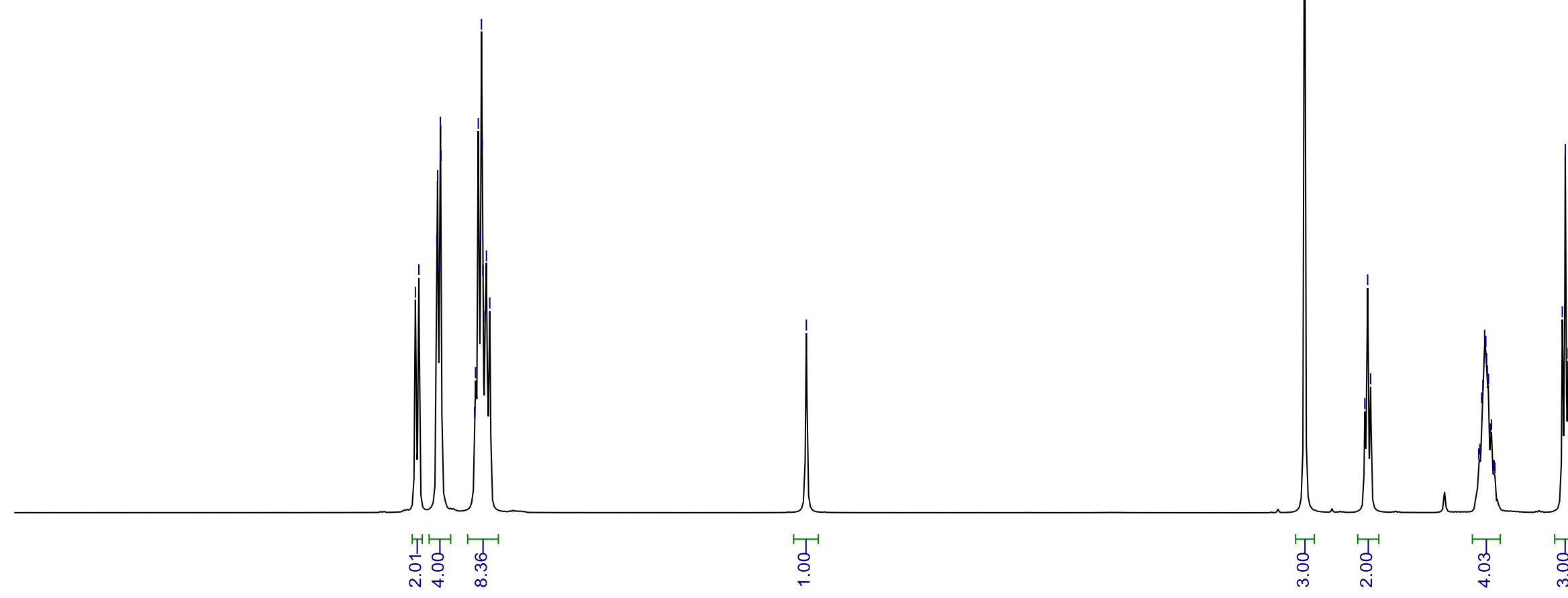

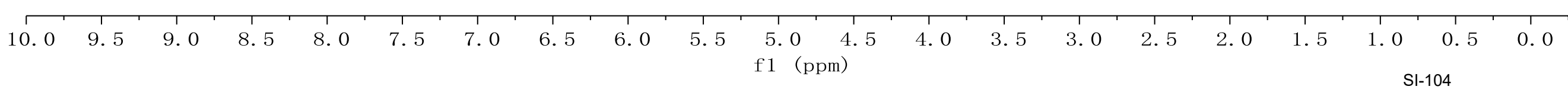



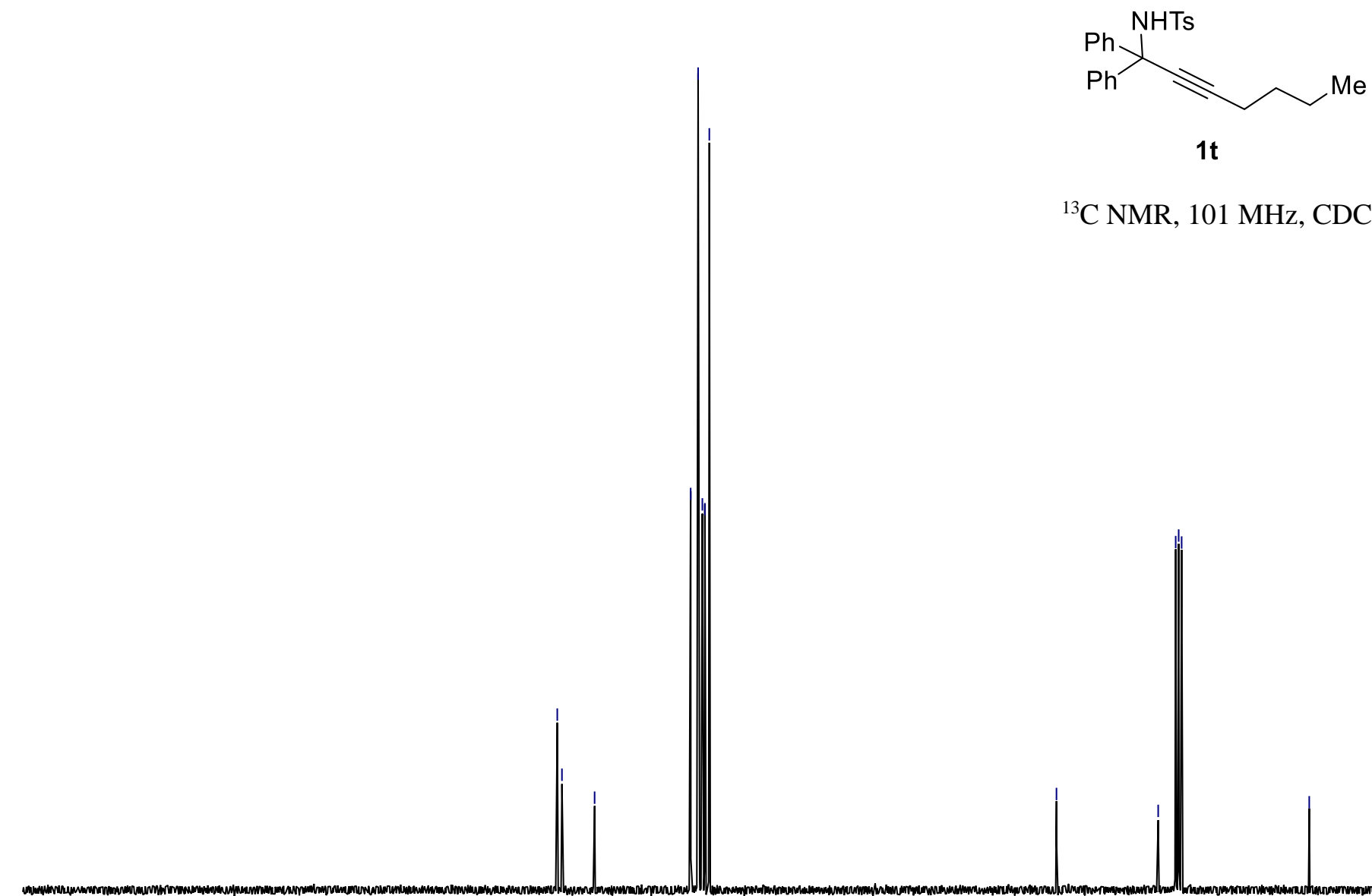

${ }^{13} \mathrm{C}$ NMR, $101 \mathrm{MHz}, \mathrm{CDCl}_{3}$

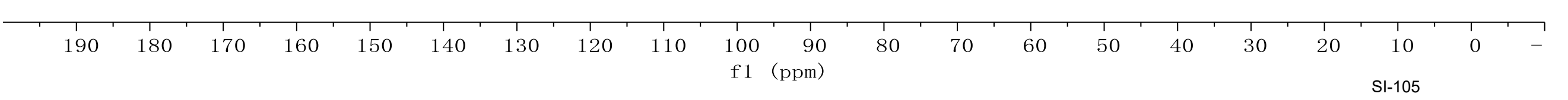




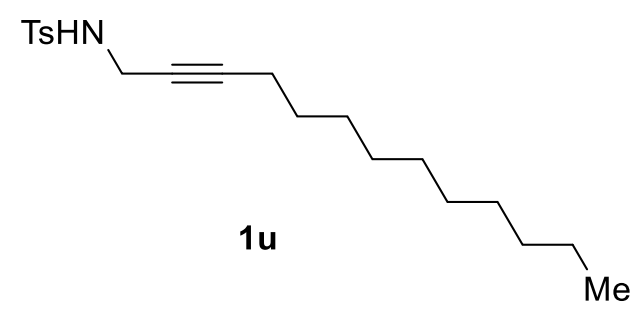

${ }^{1} \mathrm{H}$ NMR, $500 \mathrm{MHz}, \mathrm{CDCl}_{3}$

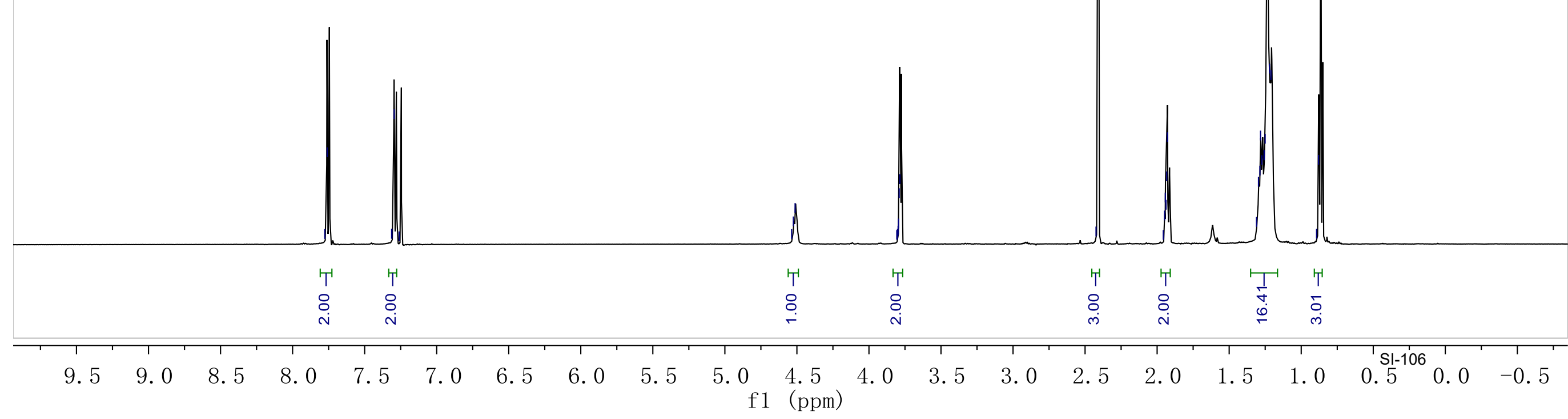


TsHN

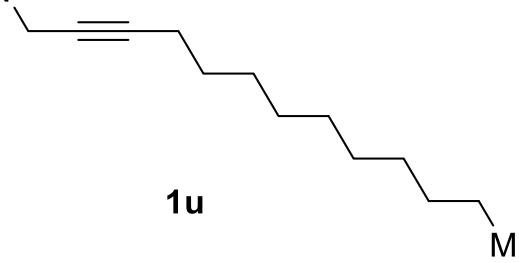

${ }^{13} \mathrm{C} \mathrm{NMR}, 126 \mathrm{MHz}, \mathrm{CDCl}_{3}$

\begin{tabular}{|c|c|c|c|c|c|c|c|c|c|c|c|c|c|c|c|c|c|c|}
\hline$T$ & $T$ & 1 & 1 & $T$ & 1 & $T$ & 7 & $T$ & 1 & $T$ & $T$ & $T$ & 1 & $T$ & $T$ & 1 & $\mid$ Sl-107 $^{\prime}$ & 1 \\
\hline 190 & 180 & 170 & 160 & 150 & 140 & 130 & 120 & 110 & $\begin{array}{l}100 \\
\mathrm{f} 1\end{array}$ & & 80 & 70 & 60 & 50 & 40 & 30 & $20 \quad 10$ & 0 \\
\hline
\end{tabular}




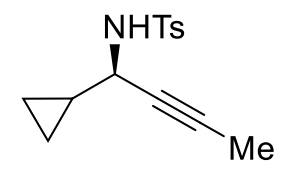

1v

${ }^{1} \mathrm{H} \mathrm{NMR}, 600 \mathrm{MHz}, \mathrm{CDCl}_{3}$

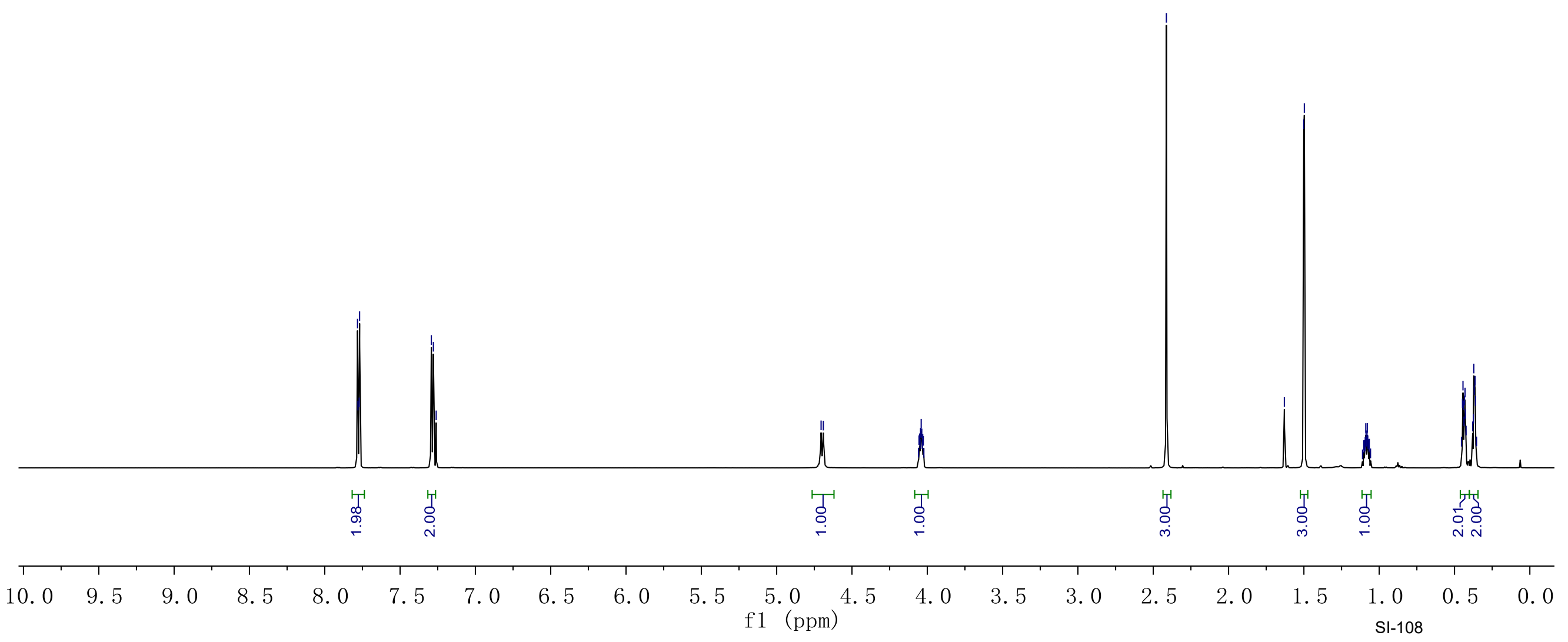



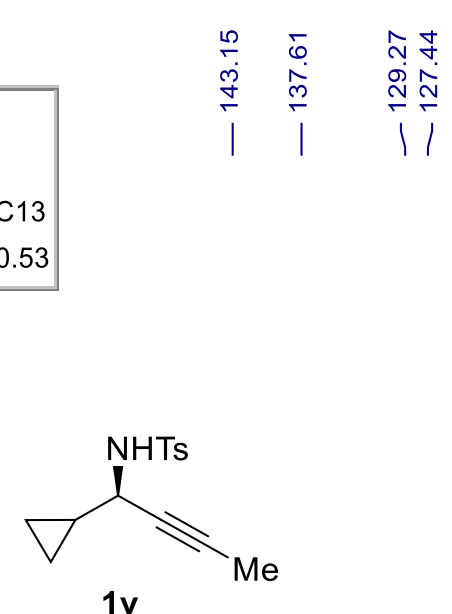

${ }^{13} \mathrm{C}$ NMR, $101 \mathrm{MHz}, \mathrm{CDCl}_{3}$

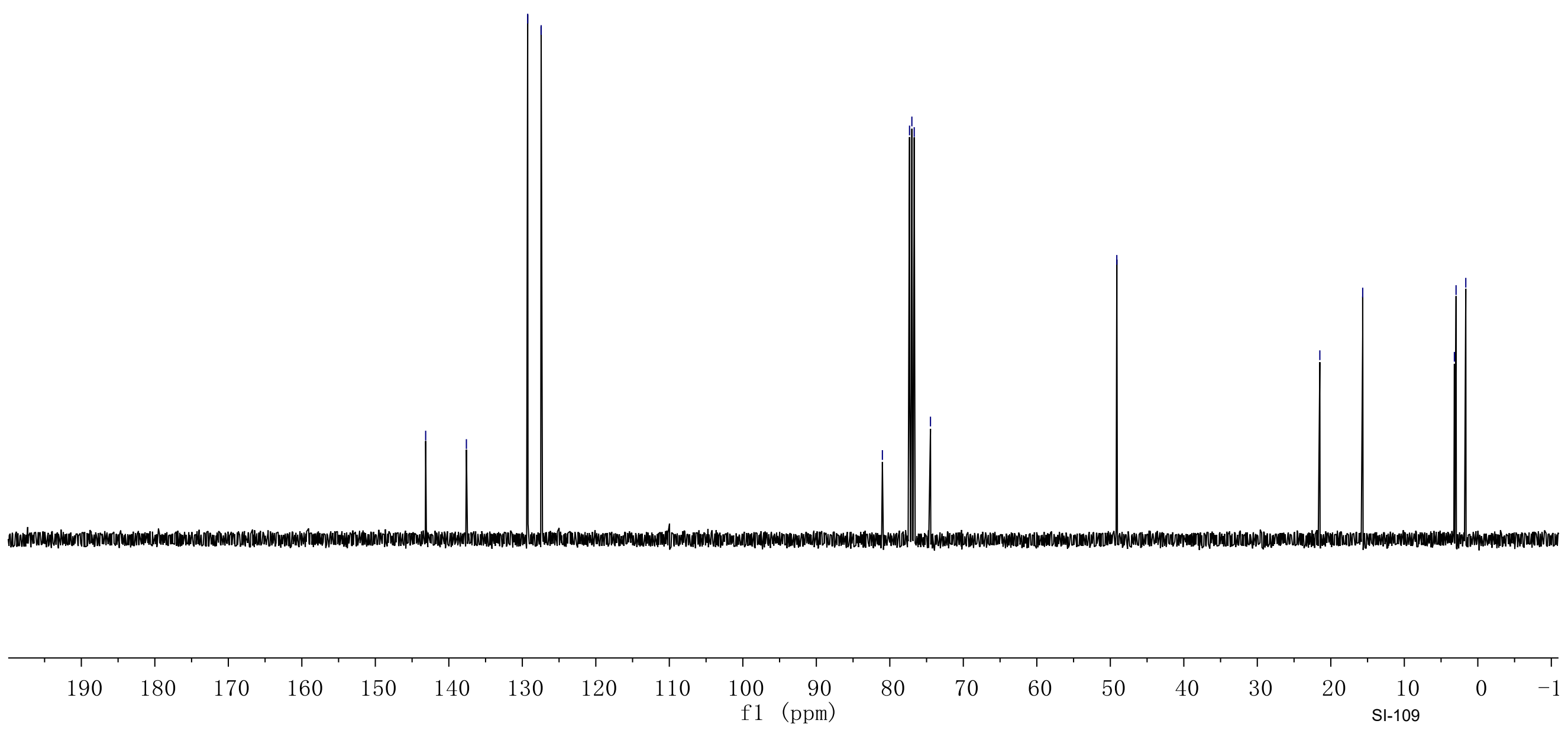




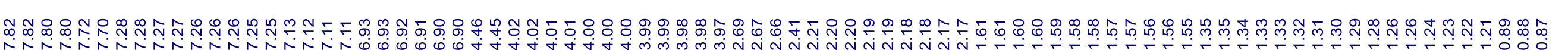

\begin{tabular}{ll}
\multicolumn{1}{c}{ Parameter } & \multicolumn{1}{c|}{ Value } \\
Title & cxp-6-235-p.1.fid \\
Solvent & $\mathrm{CDCl} 3$ \\
Experiment & $1 \mathrm{D}$ \\
Spectrometer Frequency & 500.15 \\
Nucleus & $1 \mathrm{H}$
\end{tabular}

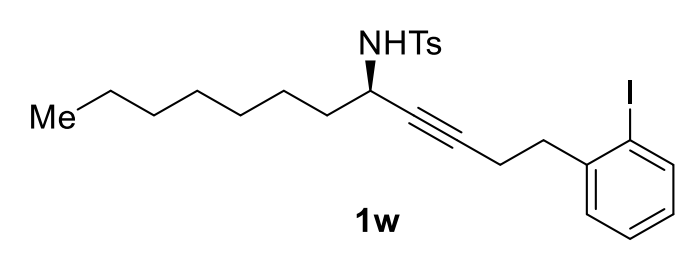

${ }^{1} \mathrm{H} \mathrm{NMR}, 500 \mathrm{MHz}, \mathrm{CDCl}_{3}$

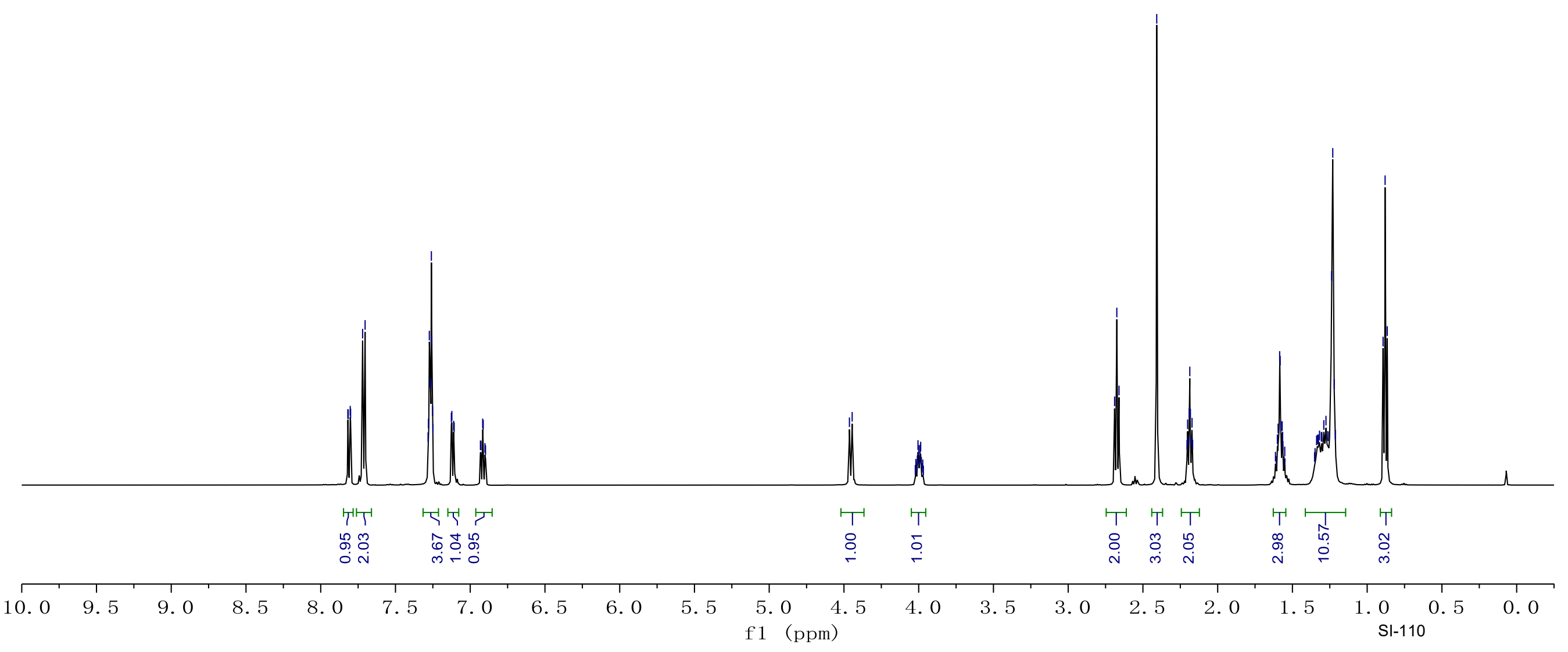


Experiment

$1 \mathrm{D}$

Spectrometer Frequency 125.78

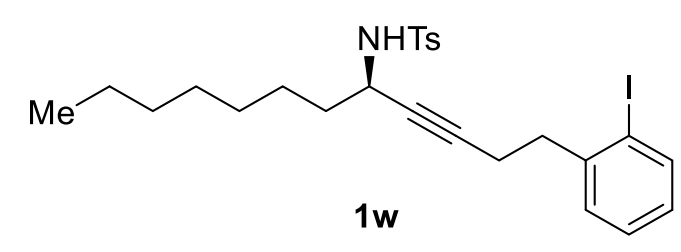

${ }^{13} \mathrm{C} \mathrm{NMR}, 126 \mathrm{MHz}, \mathrm{CDCl}_{3}$
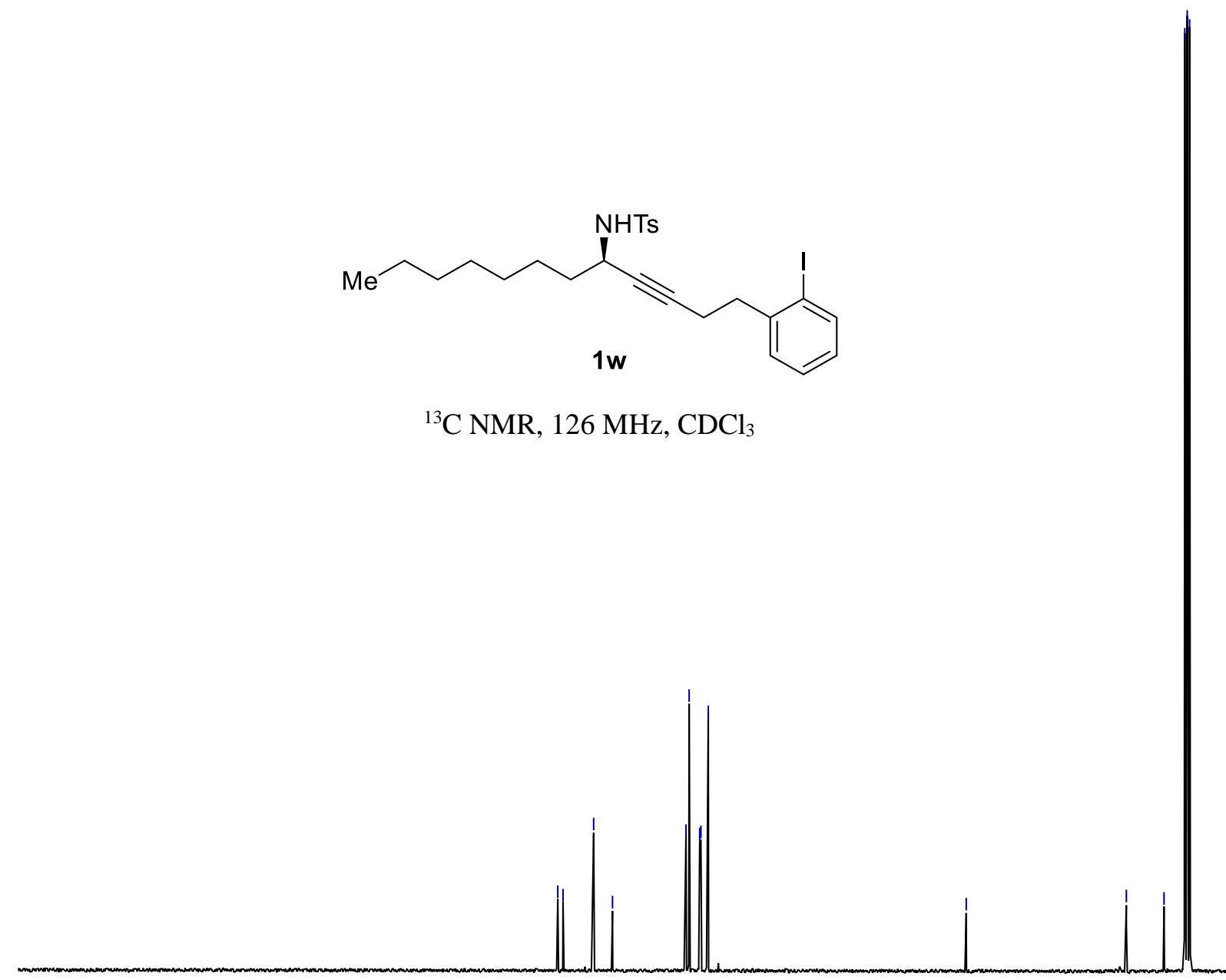

\section{0}




\begin{tabular}{|lr|}
\hline \multicolumn{2}{|c|}{ Parameters } \\
Title & \multicolumn{1}{c|}{ Value } \\
Solvent & $\mathrm{cdp}-4-301-3-\mathrm{p}-\mathrm{H} 1$ \\
Spectrometer 3 \\
\hline
\end{tabular}

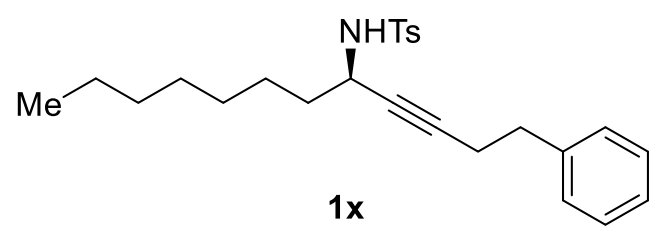

${ }^{1} \mathrm{H} \mathrm{NMR}, 500 \mathrm{MHz}, \mathrm{CDCl}_{3}$

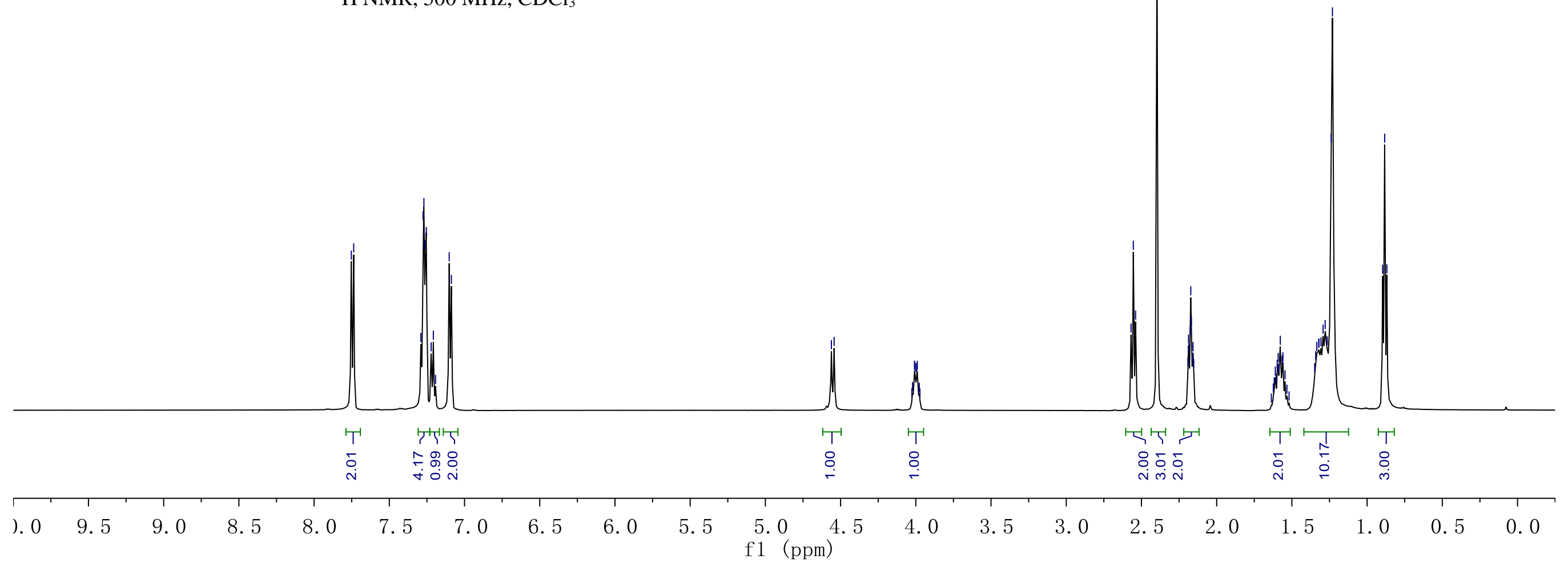




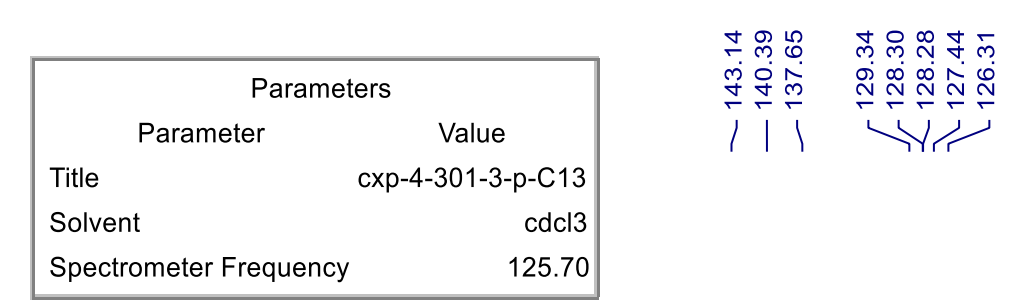

Spectrometer Frequency

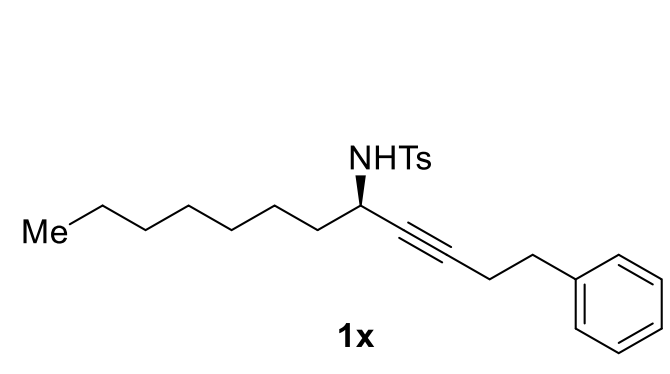

${ }^{13} \mathrm{C} \mathrm{NMR}, 126 \mathrm{MHz}, \mathrm{CDCl}_{3}$

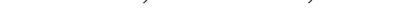

\begin{tabular}{|c|c|c|c|c|c|c|c|c|c|c|c|c|c|c|c|c|c|c|c|c|}
\hline 190 & 180 & 170 & 160 & 150 & 140 & 130 & 120 & 110 & $\begin{array}{r}100 \\
\mathrm{f} 1\end{array}$ & $\begin{array}{r}90 \\
(\mathrm{ppm})\end{array}$ & 80 & 70 & 60 & 50 & 40 & 30 & 20 & 10 & 0 & - \\
\hline
\end{tabular}




\begin{tabular}{|c|c|}
\hline \multicolumn{2}{|c|}{ Parameters } \\
\hline Parameter & Value \\
\hline Title & cxp-3-188-p-H1 \\
\hline Spectrometer Frequency & 599.64 \\
\hline
\end{tabular}

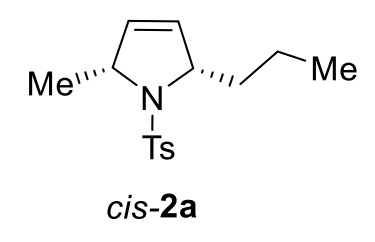

${ }^{1} \mathrm{H} \mathrm{NMR}, 600 \mathrm{MHz}, \mathrm{CDCl}_{3}$

d.r. $=97 / 3$

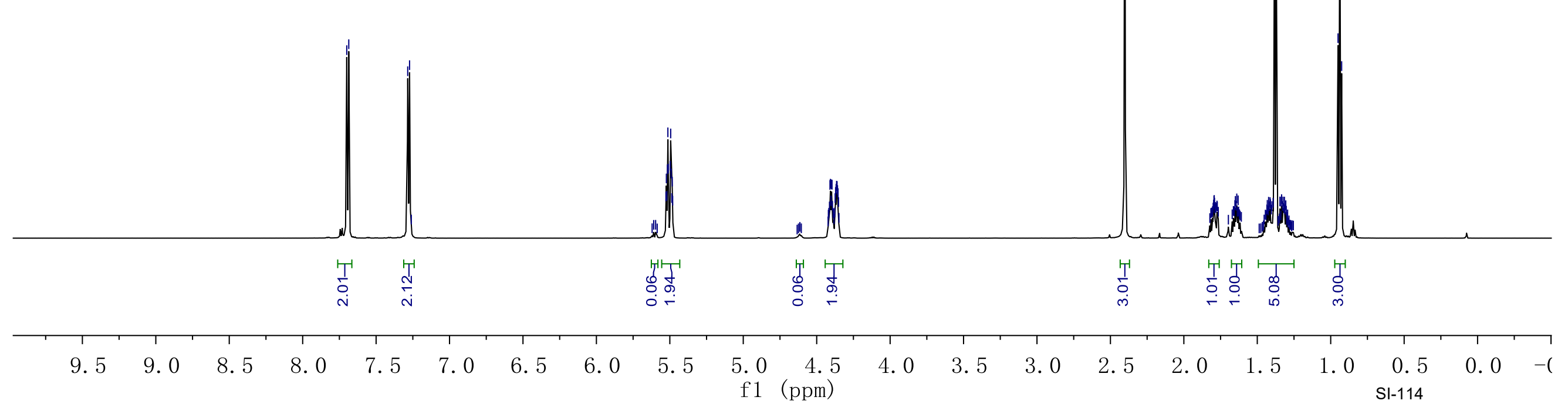




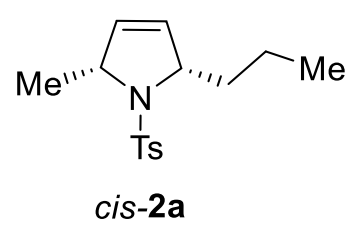

${ }^{13} \mathrm{C} \mathrm{NMR}, 126 \mathrm{MHz}, \mathrm{CDCl}_{3}$
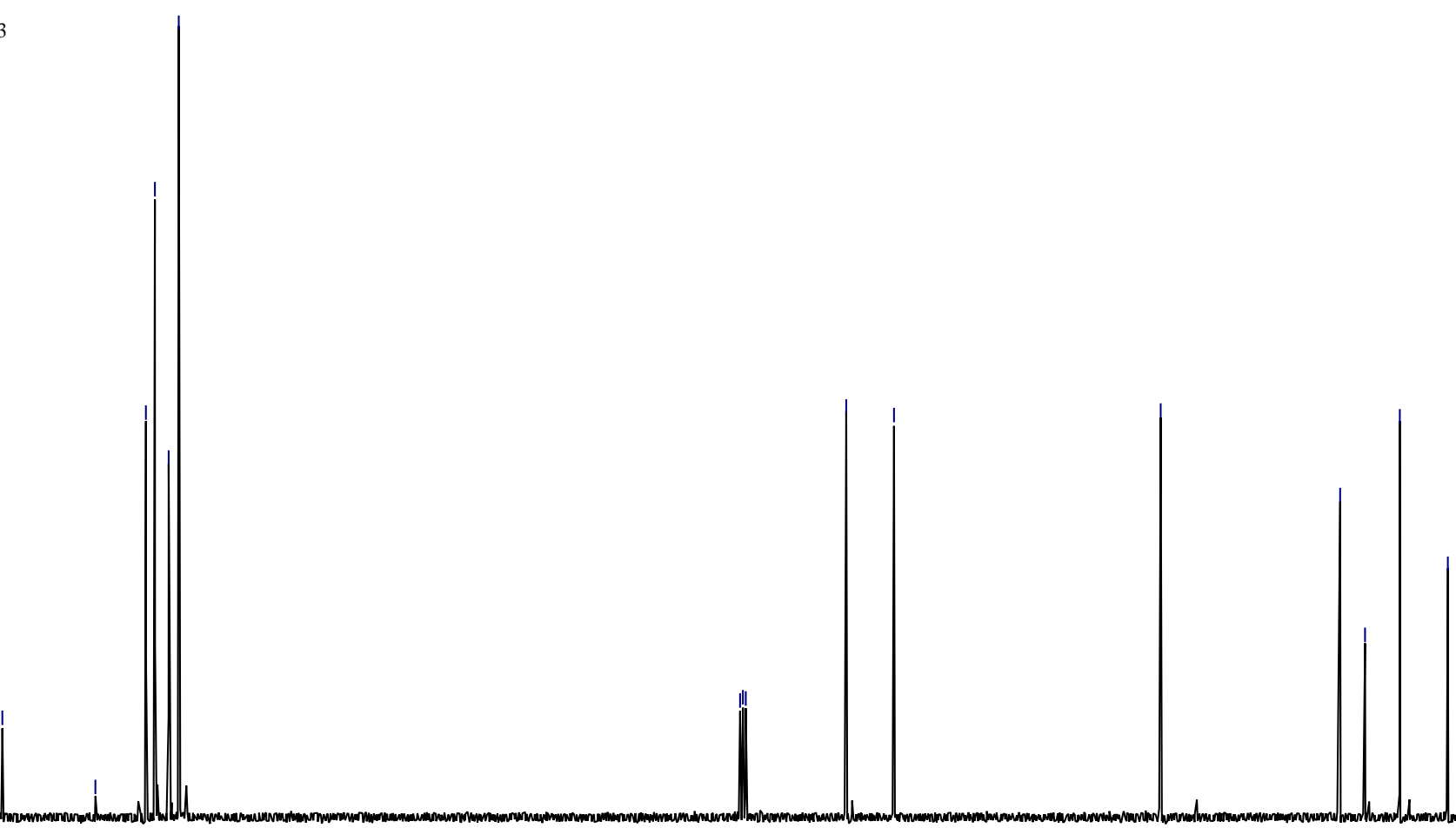

\begin{tabular}{|c|c|c|c|c|c|c|c|c|c|c|c|c|c|c|c|c|c|}
\hline 20 & 190 & 180 & 170 & $\begin{array}{l}1 \\
160\end{array}$ & 150 & 140 & 130 & 120 & 110 & $\begin{array}{l}100 \\
100 \\
f 1 \quad(p p m)\end{array}$ & 90 & 80 & 70 & 6 & 40 & 30 & $\begin{array}{cc}1 & 1 \\
20 & 10\end{array}$ \\
\hline
\end{tabular}




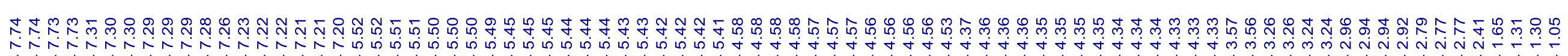

\section{Parameters \\ Parameter}

Title

Value

Spectrometer Frequency cxp-3-191-p-H1

599.64

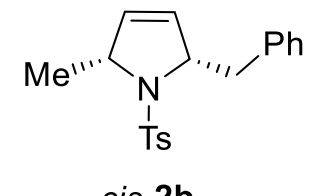

cis-2b

${ }^{1} \mathrm{H}$ NMR, $600 \mathrm{MHz}, \mathrm{CDCl}_{3}$

$$
\text { d. } r .=96 / 4
$$
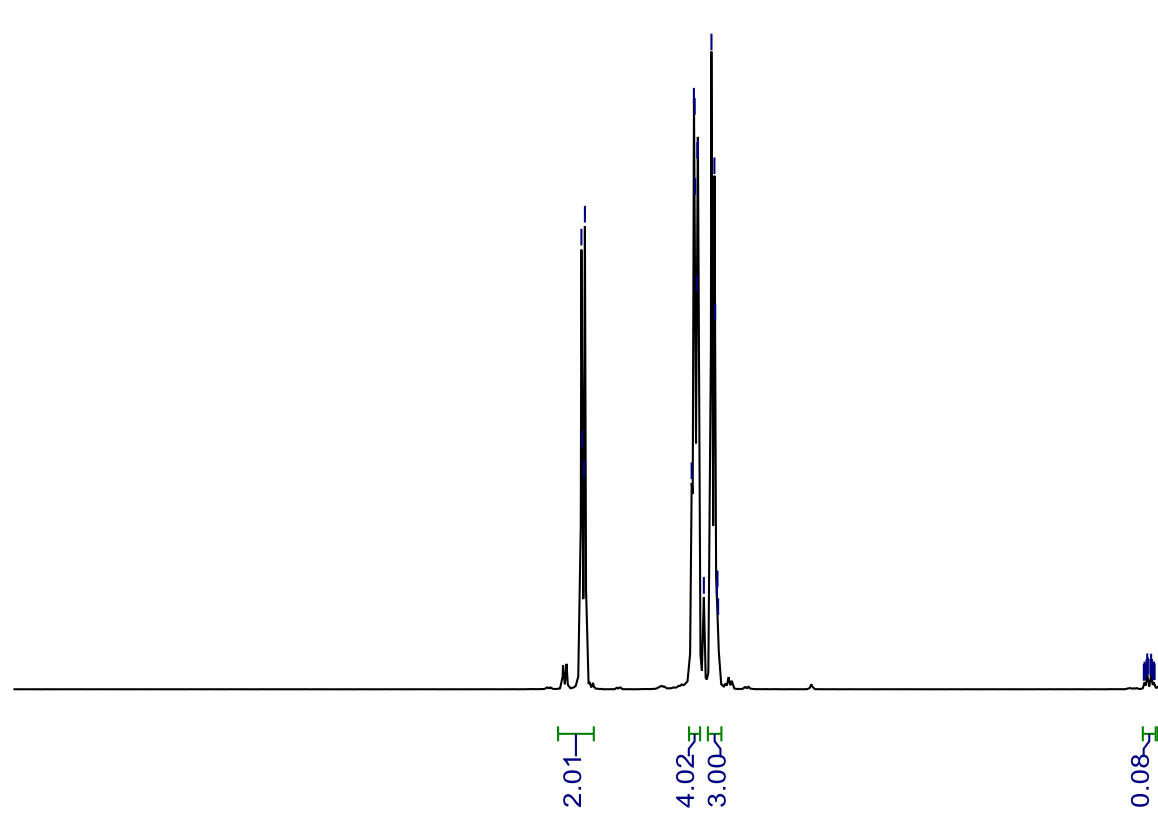

9.59 .0

8. 5

8. 0

7. 5

7. 0

6.5

6. 0

5.5

5. 0

(ppm)

4. 0

3.5

2.5

2.0

1.5

1. $\mathrm{Sl}_{-116} 0.5$

0.0 


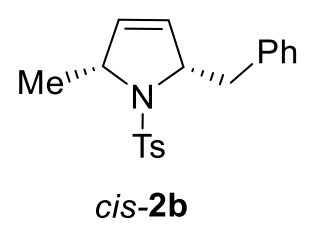

${ }^{13} \mathrm{C} \mathrm{NMR,} 151 \mathrm{MHz}, \mathrm{CDCl}_{3}$

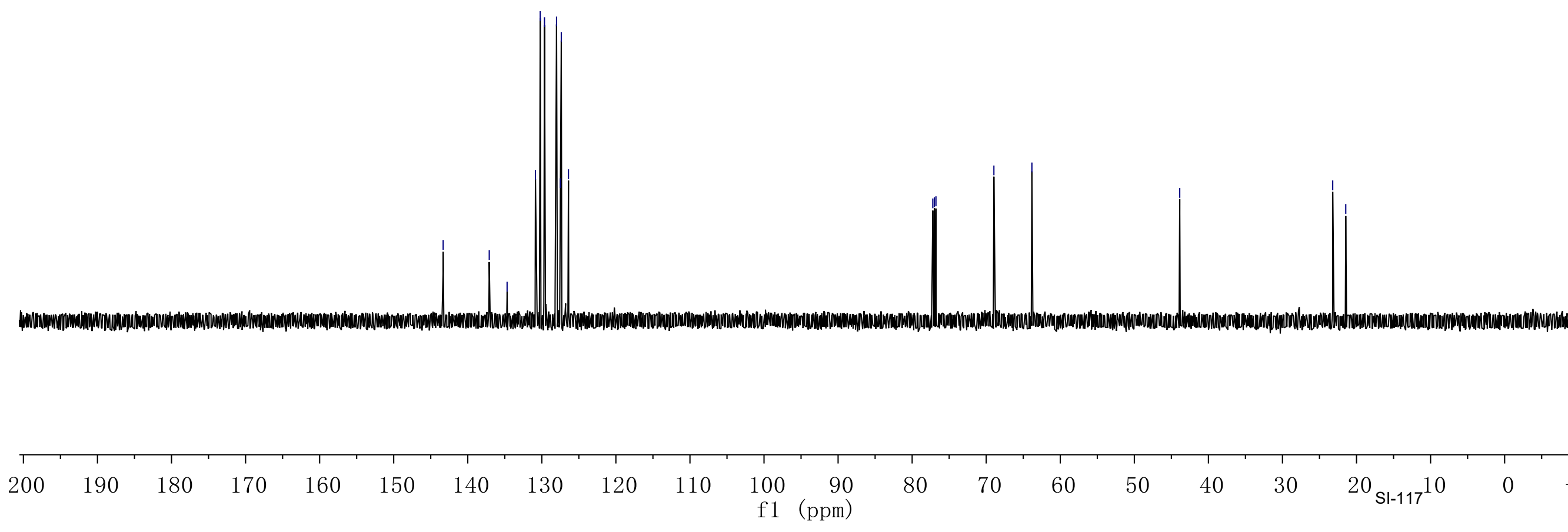




\begin{tabular}{|lrr|}
\hline \multicolumn{3}{|c|}{ Parameters } \\
Title & Parameter & \multicolumn{1}{c|}{ Value } \\
Spectrometer Frequency & cxp-3-192-p-H1 \\
\hline
\end{tabular}

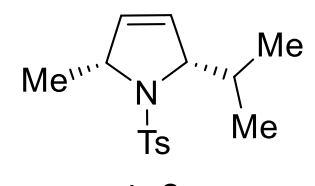

cis-2c

${ }^{1} \mathrm{H} \mathrm{NMR}, 600 \mathrm{MHz}, \mathrm{CDCl}_{3}$

$$
\text { d.r. }=98 / 2
$$
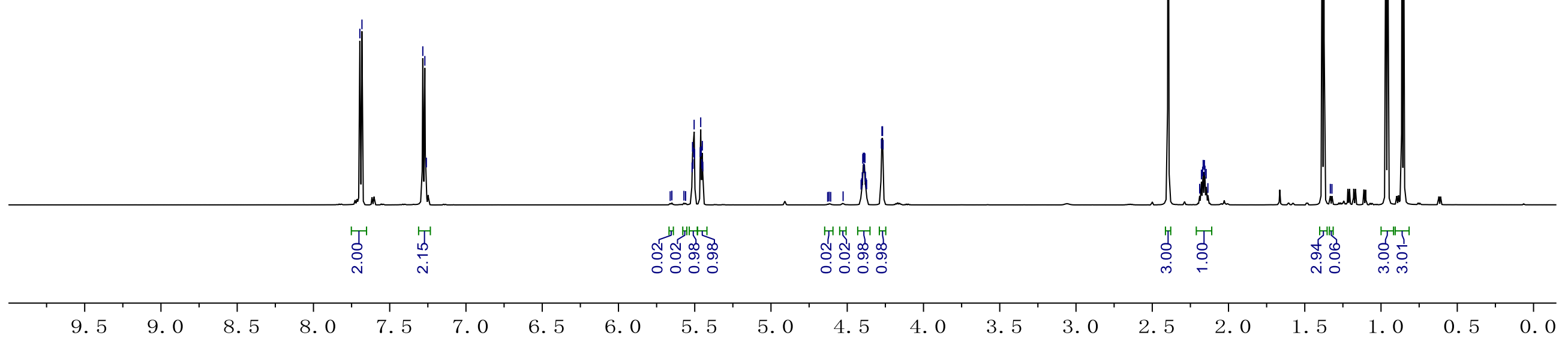

8. 5

8. 0

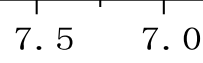

6.5

6. 0

5. 5

$5.0 \quad 4.5$
f1 (ppm)

4. $0 \quad 3.5$

3. 0

2.5

2. 0

1.5

1. 0

0. 5 0.0 


$$
\mathrm{Me}_{\substack{\prime \prime \prime \\ \text { cis-2c }}}
$$

${ }^{13} \mathrm{C} \mathrm{NMR}, 151 \mathrm{MHz}, \mathrm{CDCl}_{3}$

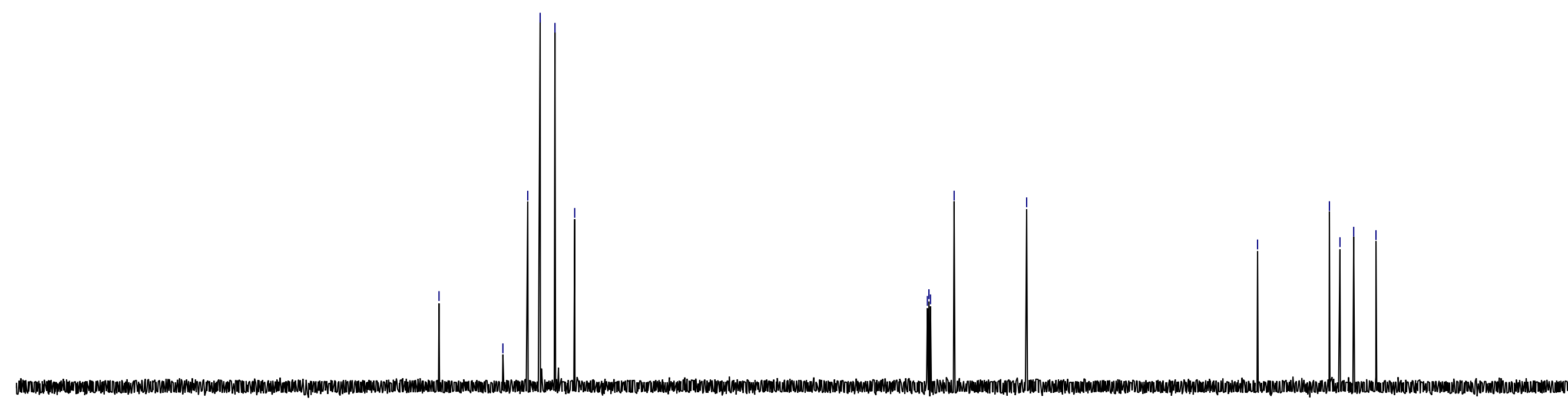

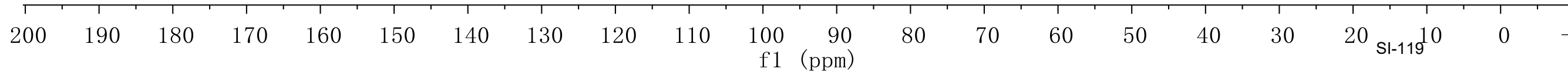




\begin{tabular}{|c|c|}
\hline \multicolumn{2}{|c|}{ Parameters } \\
\hline Parameter & Value \\
\hline Title & cxp-3-193-p-H1 \\
\hline Spectrometer Frequency & 599.64 \\
\hline
\end{tabular}

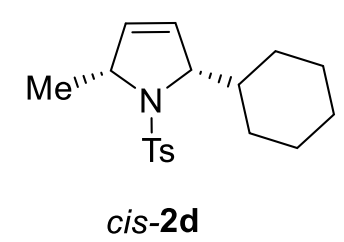

${ }^{1} \mathrm{H} \mathrm{NMR}, 600 \mathrm{MHz}, \mathrm{CDCl}_{3}$

d.r. $=98 / 2$

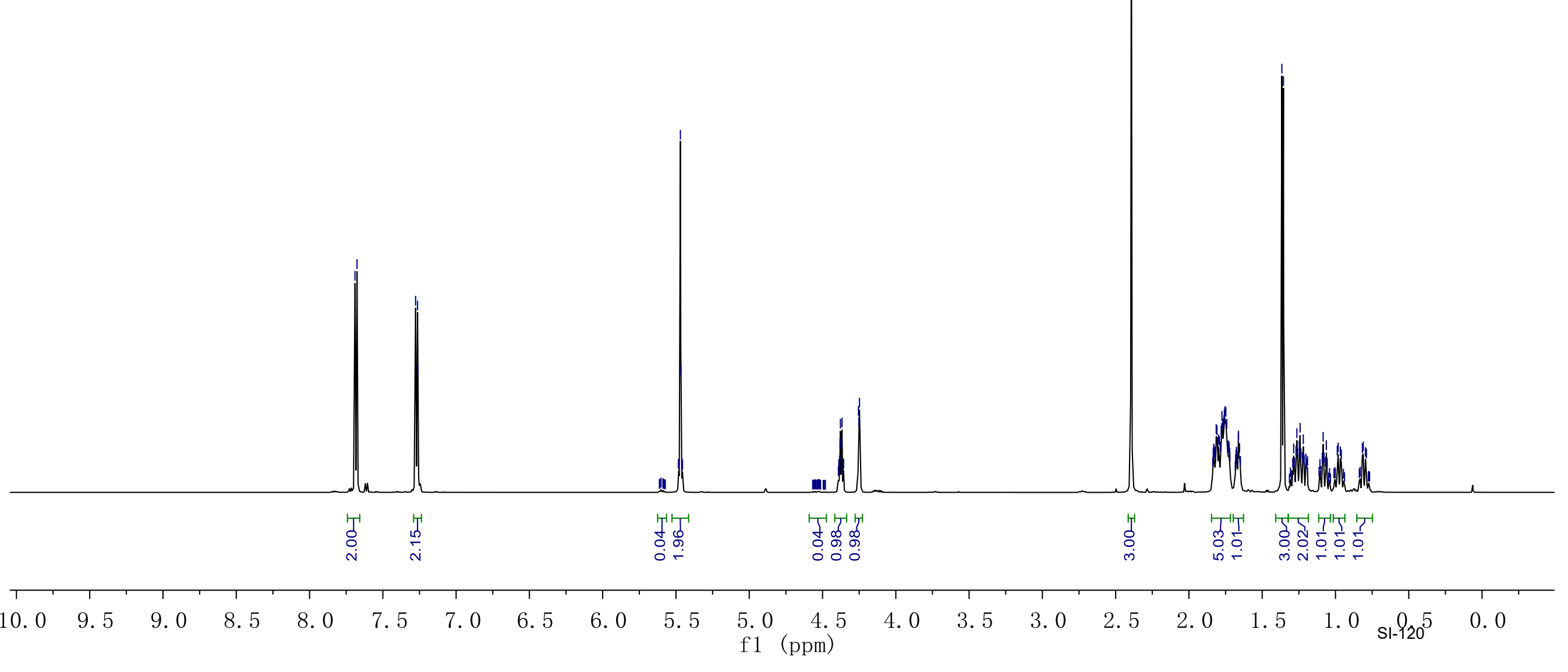




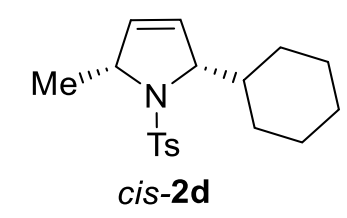

${ }^{13} \mathrm{C} \mathrm{NMR,} 101 \mathrm{MHz}, \mathrm{CDCl}_{3}$

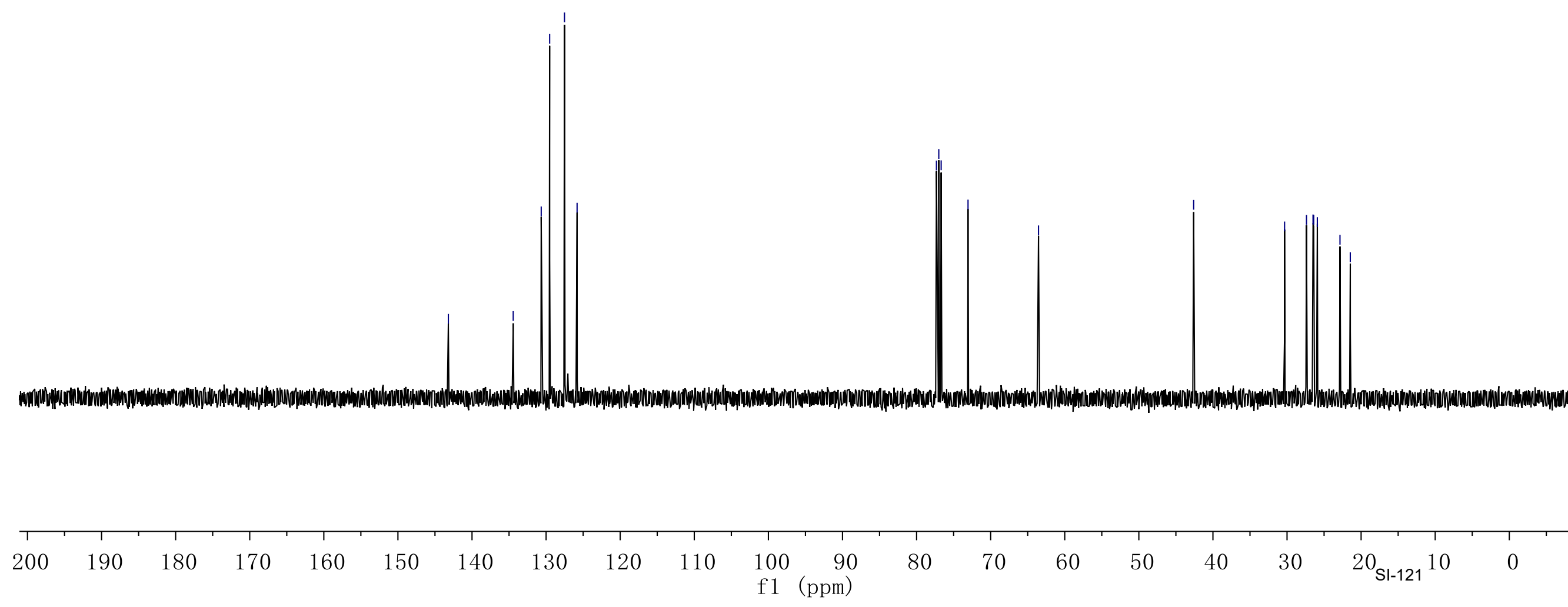




\begin{tabular}{|lr|}
\hline \multicolumn{3}{|c|}{ Parameters } \\
\hline \multicolumn{3}{|c|}{ Parameter } & \multicolumn{1}{c|}{ Value } \\
Title & cxp-3-197-p-H1 \\
Spectrometer Frequency & 599.64 \\
\hline
\end{tabular}<smiles>[3H]N1[C@H](C)C=C[C@H]1CCCl</smiles>

${ }^{1} \mathrm{H}$ NMR, $600 \mathrm{MHz}, \mathrm{CDCl}_{3}$

$$
\text { d.r. }=98 / 2
$$

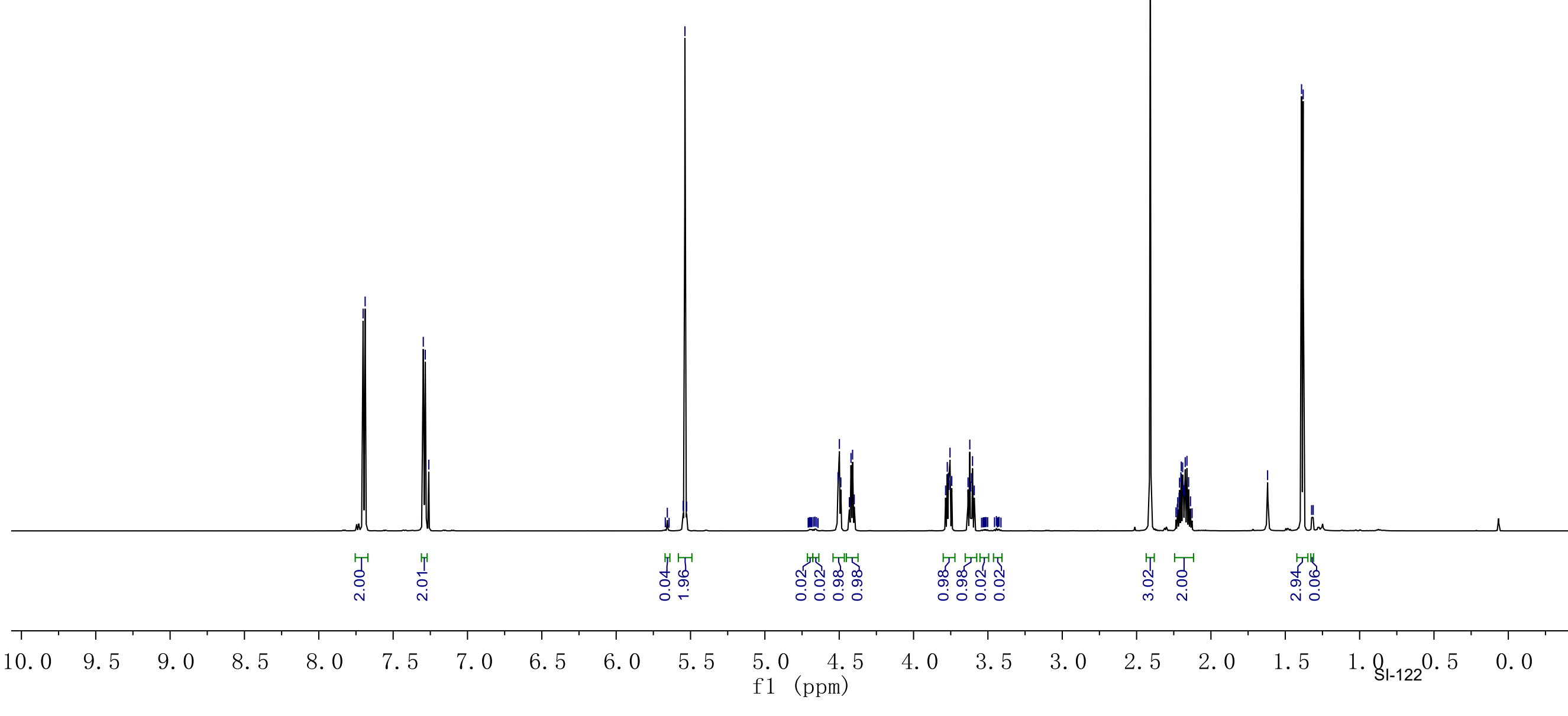




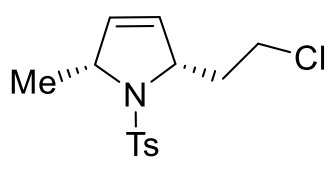

$$
\begin{aligned}
& \text { cis-2e }
\end{aligned}
$$

${ }^{13} \mathrm{C}$ NMR, $101 \mathrm{MHz}, \mathrm{CDCl}_{3}$

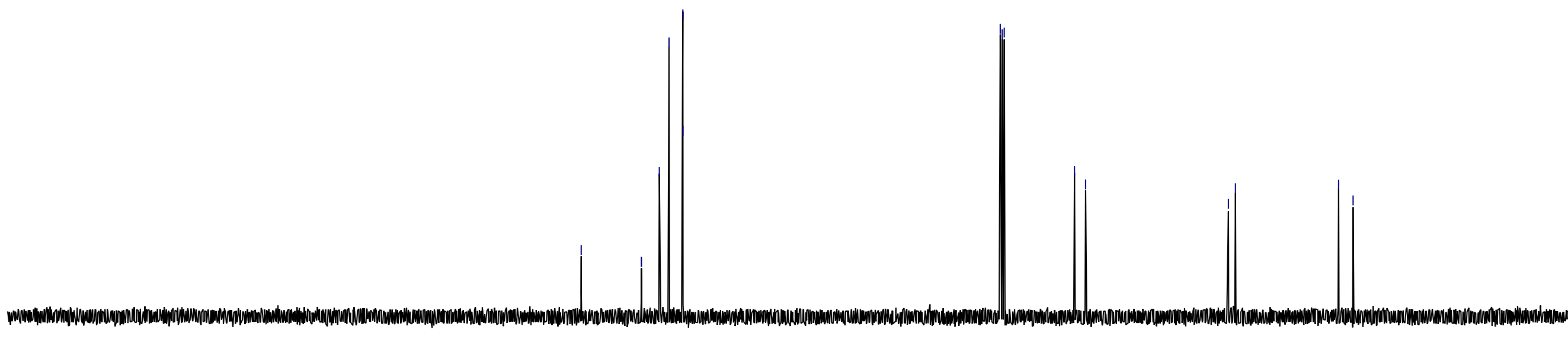

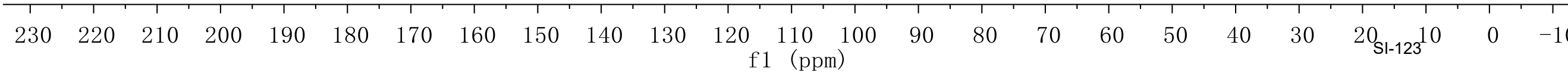




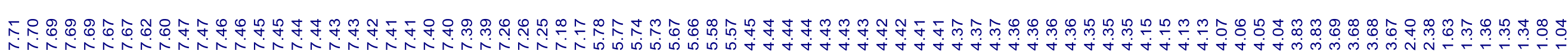

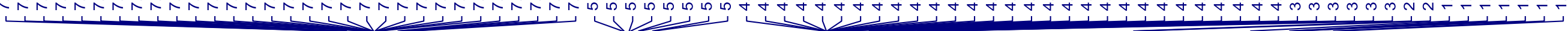

\begin{tabular}{|lr|}
\hline \multicolumn{3}{|c|}{ Parameters } \\
Parameter & \multicolumn{1}{c|}{ Value } \\
Title & cxp-3-206-p-H1 \\
Spectrometer Frequency & 599.64 \\
\hline
\end{tabular}

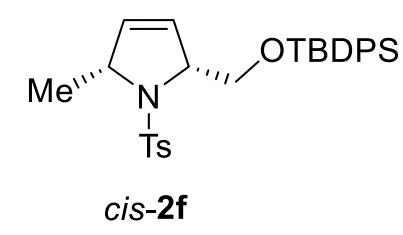

${ }^{1} \mathrm{H} \mathrm{NMR}, 600 \mathrm{MHz}, \mathrm{CDCl}_{3}$

d.r. $=94 / 6$

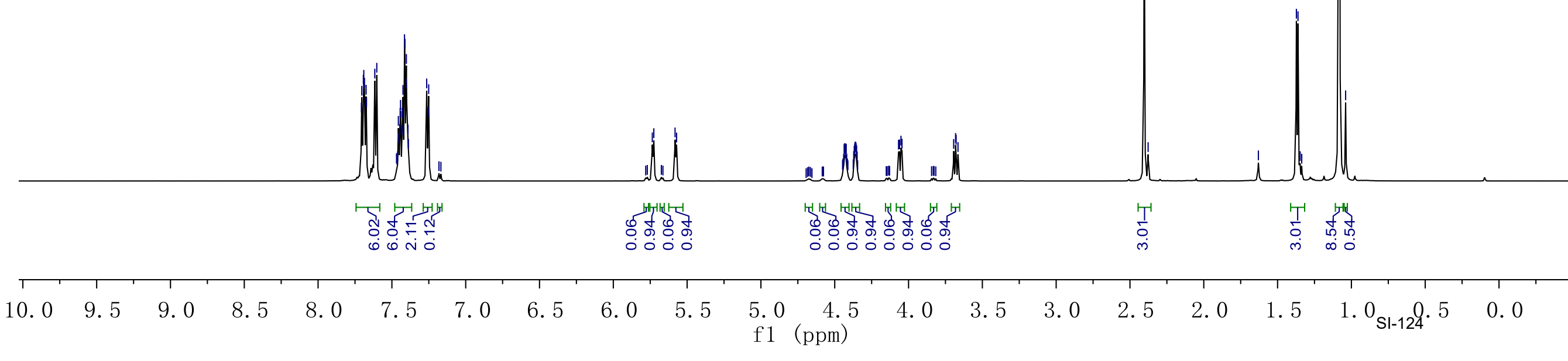


Spectrometer Frequency 100.53

$$
\begin{aligned}
& \mathrm{Me}^{\prime \prime \prime} \prod_{\substack{\mathrm{N} \\
1}} \prod_{\text {Ts }} \text { OTBDPS } \\
& \text { cis-2f }
\end{aligned}
$$

${ }^{13} \mathrm{C}$ NMR, $101 \mathrm{MHz}, \mathrm{CDCl}_{3}$

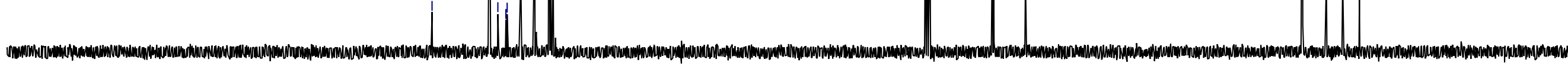

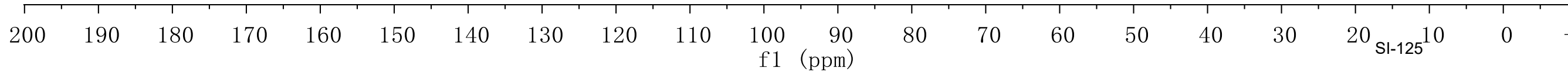




\begin{tabular}{|lr|}
\hline \multicolumn{2}{|c|}{ Parameters } \\
Title & \multicolumn{1}{c|}{ Value } \\
Solvent & cxp-4-142-p-2-H1 \\
Spectrometer Frequency & cdc13 \\
\hline
\end{tabular}

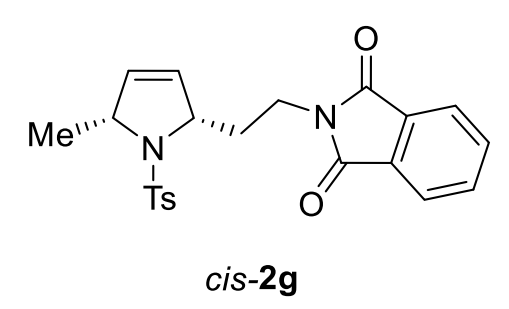

${ }^{1} \mathrm{H}$ NMR, $500 \mathrm{MHz}, \mathrm{CDCl}_{3}$

d. $r .=96 / 4$

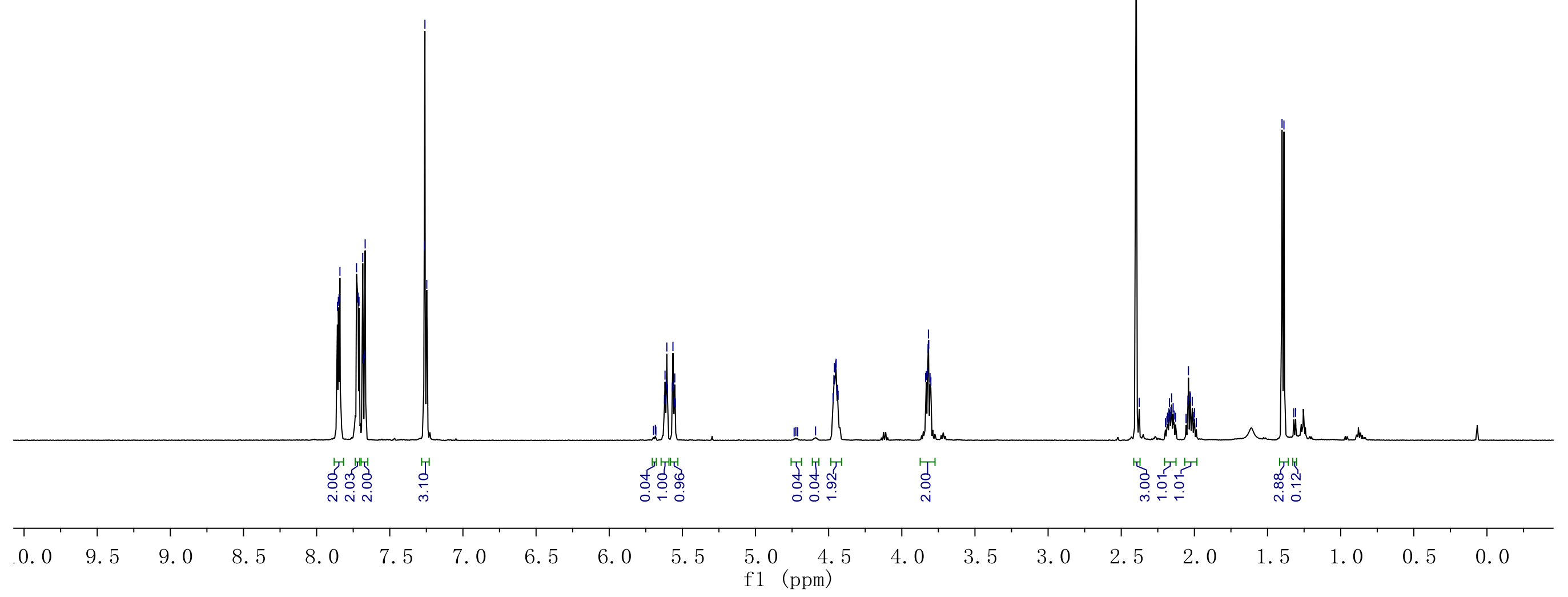




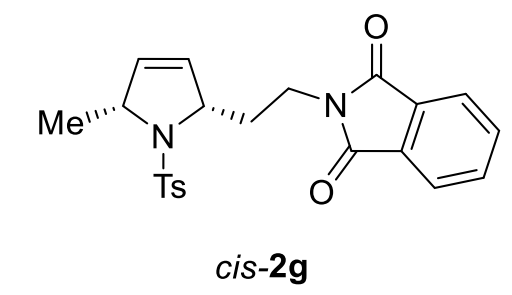

${ }^{13} \mathrm{C} \mathrm{NMR}, 126 \mathrm{MHz}, \mathrm{CDCl}_{3}$

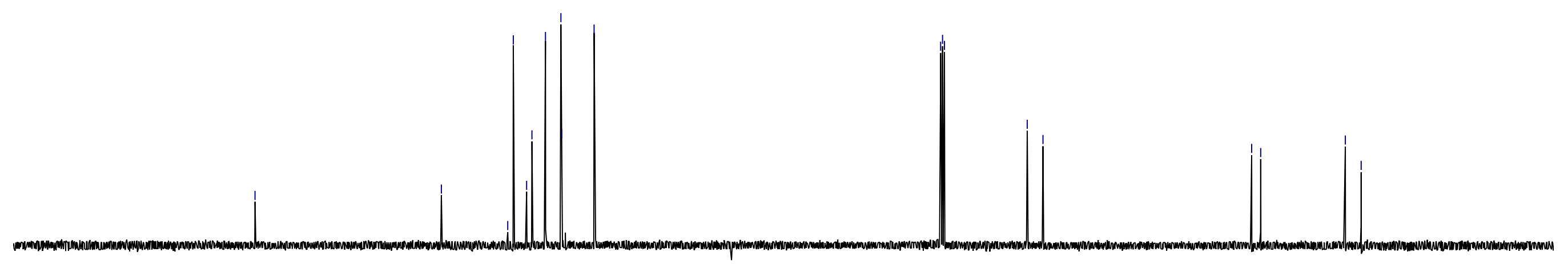

\begin{tabular}{|c|c|c|c|c|c|c|c|c|c|c|c|c|c|c|c|c|c|c|c|c|}
\hline 00 & 190 & 180 & 170 & 160 & 150 & 140 & 130 & 120 & 110 & $\begin{array}{l}100 \\
\mathrm{f} 1 \quad(\mathrm{pp}\end{array}$ & 90 & 80 & 70 & 60 & 50 & 40 & 30 & 20 & 10 & 0 \\
\hline
\end{tabular}




\begin{tabular}{|lr|}
\hline \multicolumn{3}{|c|}{ Parameters } \\
Parameter & \multicolumn{1}{c|}{ Value } \\
Title & cxp-3-218-p-H1 \\
Spectrometer Frequency & 599.64 \\
\hline
\end{tabular}

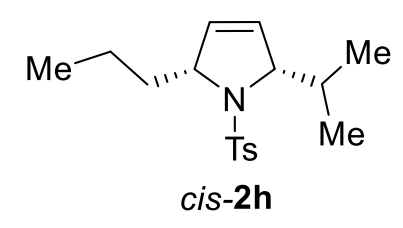

${ }^{1} \mathrm{H} \mathrm{NMR}, 600 \mathrm{MHz}, \mathrm{CDCl}_{3}$

d.r. $>50 / 1$

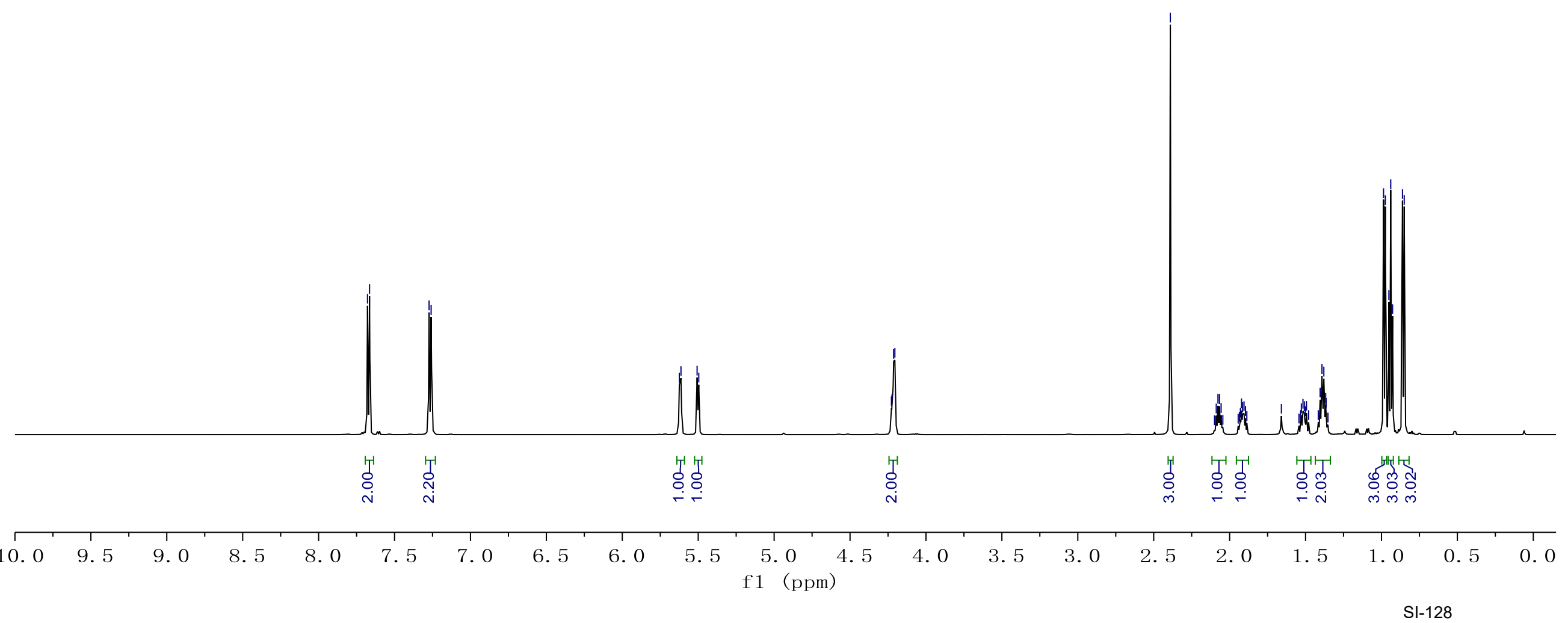




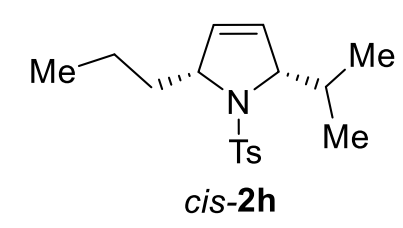

${ }^{13} \mathrm{C} \mathrm{NMR}, 151 \mathrm{MHz}, \mathrm{CDCl}_{3}$

d.r. $>50 / 1$
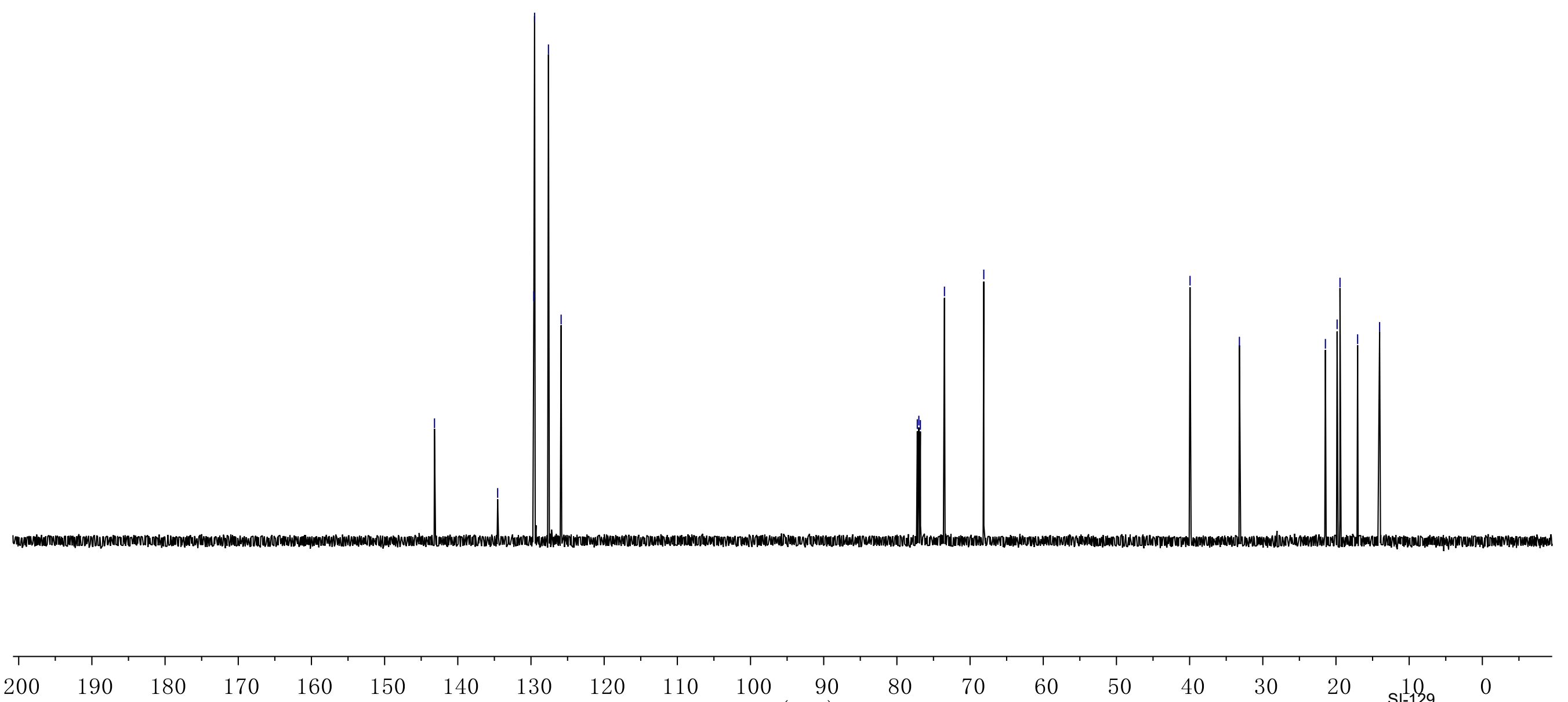

140

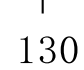

120

110

$\begin{array}{lr}100 & 90 \\ f 1 & (\mathrm{ppm})\end{array}$

80

70

60

50

40

$30 \quad 20$

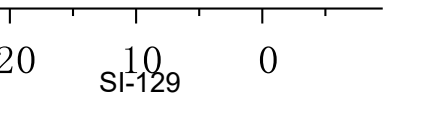




\begin{tabular}{|c|c|}
\hline \multicolumn{2}{|c|}{ Parameters } \\
\hline Parameter & Value \\
\hline Title & cxp-3-219-p-H1 \\
\hline Spectrometer Frequenc & 599.63 \\
\hline
\end{tabular}
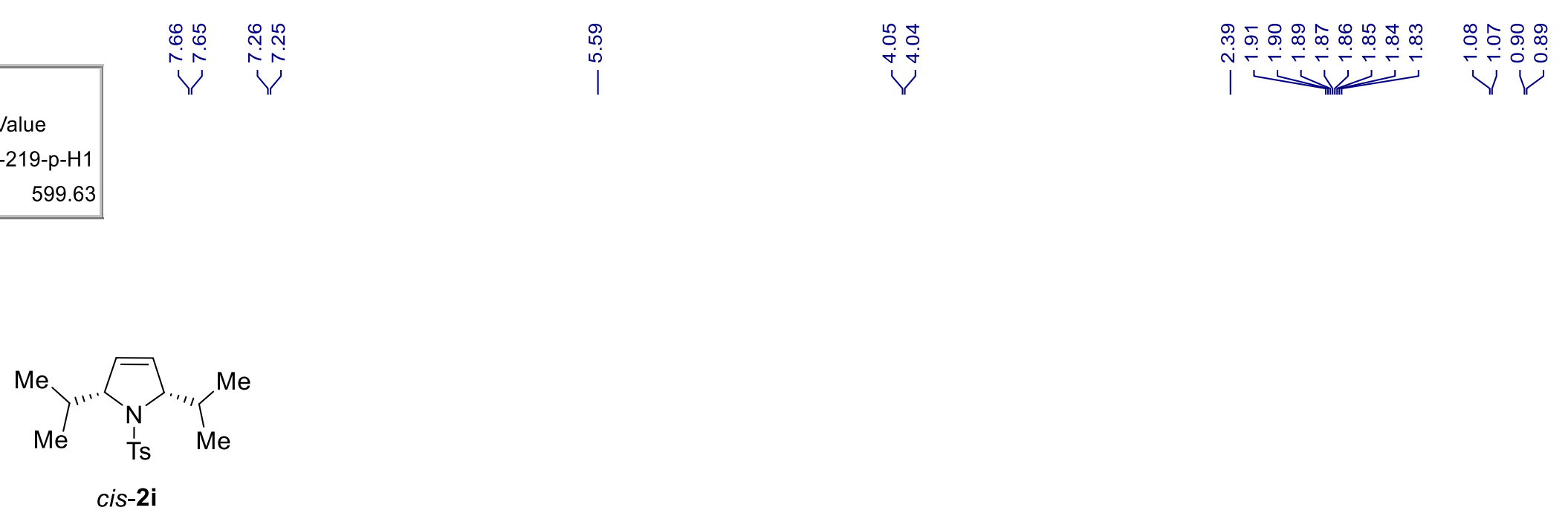

${ }^{1} \mathrm{H} \mathrm{NMR}, 600 \mathrm{MHz}, \mathrm{CDCl}_{3}$

d.r. $>50 / 1$

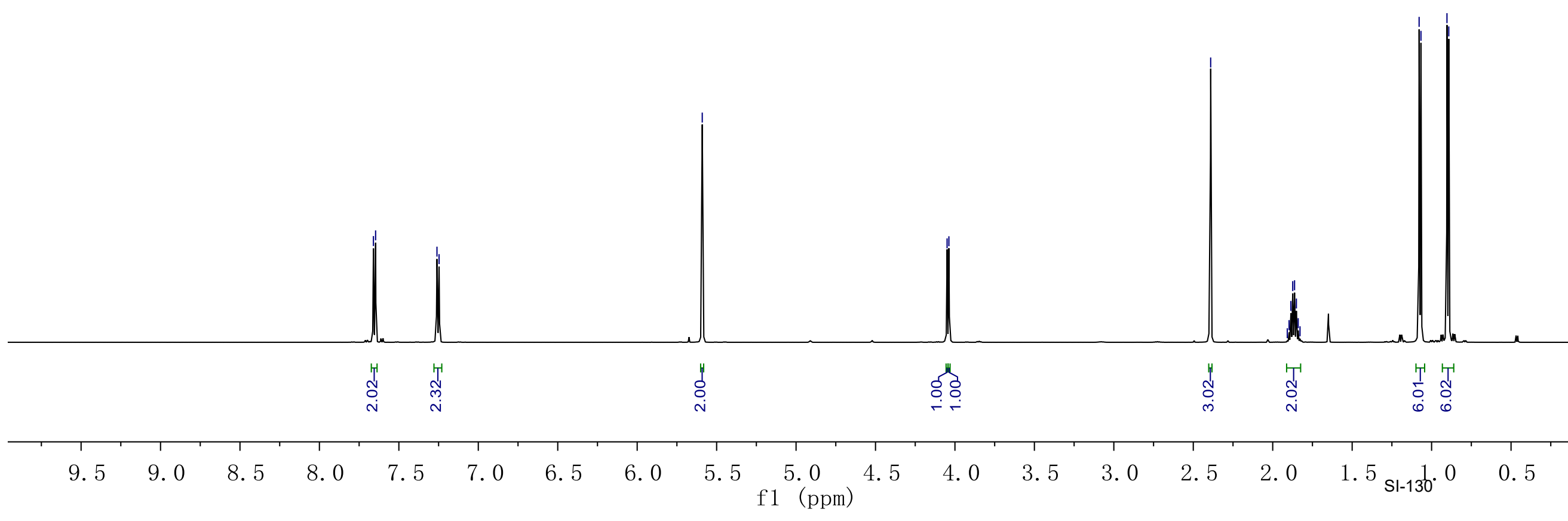




\begin{tabular}{|c|c|}
\hline \multicolumn{2}{|c|}{ Parameters } \\
\hline Parameter & Value \\
\hline Title & cxp-3-219-p-C13 \\
\hline Spectrometer Frequency & 100.53 \\
\hline
\end{tabular}

Spectrometer Frequency 100.53

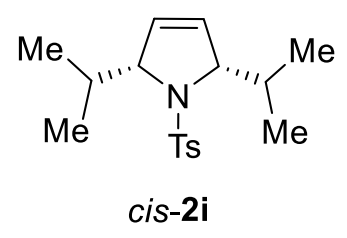

${ }^{13} \mathrm{C} \mathrm{NMR,} 101 \mathrm{MHz}, \mathrm{CDCl}_{3}$

d.r. $>50 / 1$

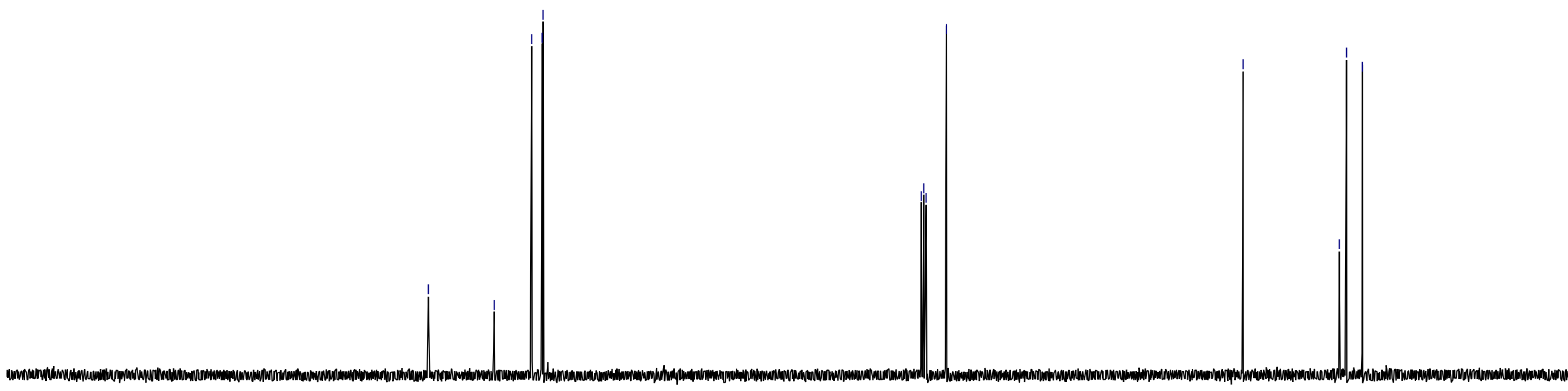

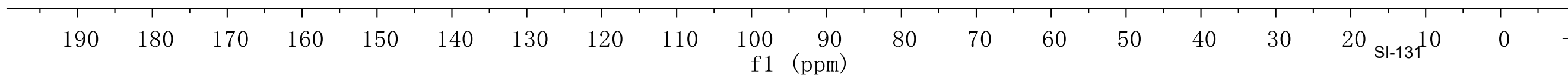




\begin{tabular}{|c|c|}
\hline \multicolumn{2}{|c|}{ Parameters } \\
\hline Parameter & Value \\
\hline Title & cxp-3-214-p-H1 \\
\hline Spectrometer Frequency & 599.64 \\
\hline
\end{tabular}

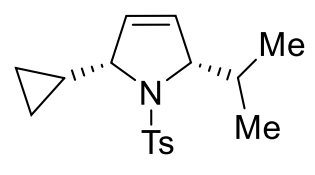

cis-2j

${ }^{1} \mathrm{H} \mathrm{NMR}, 600 \mathrm{MHz}, \mathrm{CDCl}_{3}$

d.r. $>50 / 1$

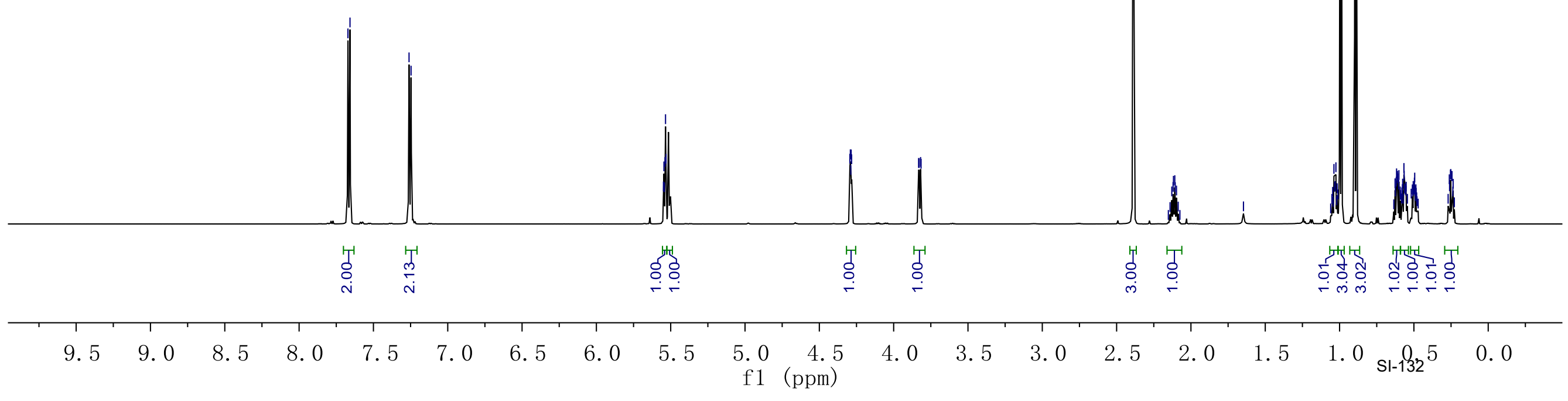




\begin{tabular}{|lr|}
\hline \multicolumn{3}{|c|}{ Parameters } \\
Title & \multicolumn{1}{c|}{ Value } \\
Spectrometer & cxp-3-214-p-C13 \\
\hline
\end{tabular}

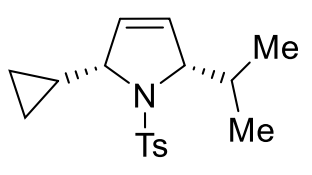

$c i s-\mathbf{2 j}$

${ }^{13} \mathrm{C}$ NMR, $101 \mathrm{MHz}, \mathrm{CDCl}_{3}$

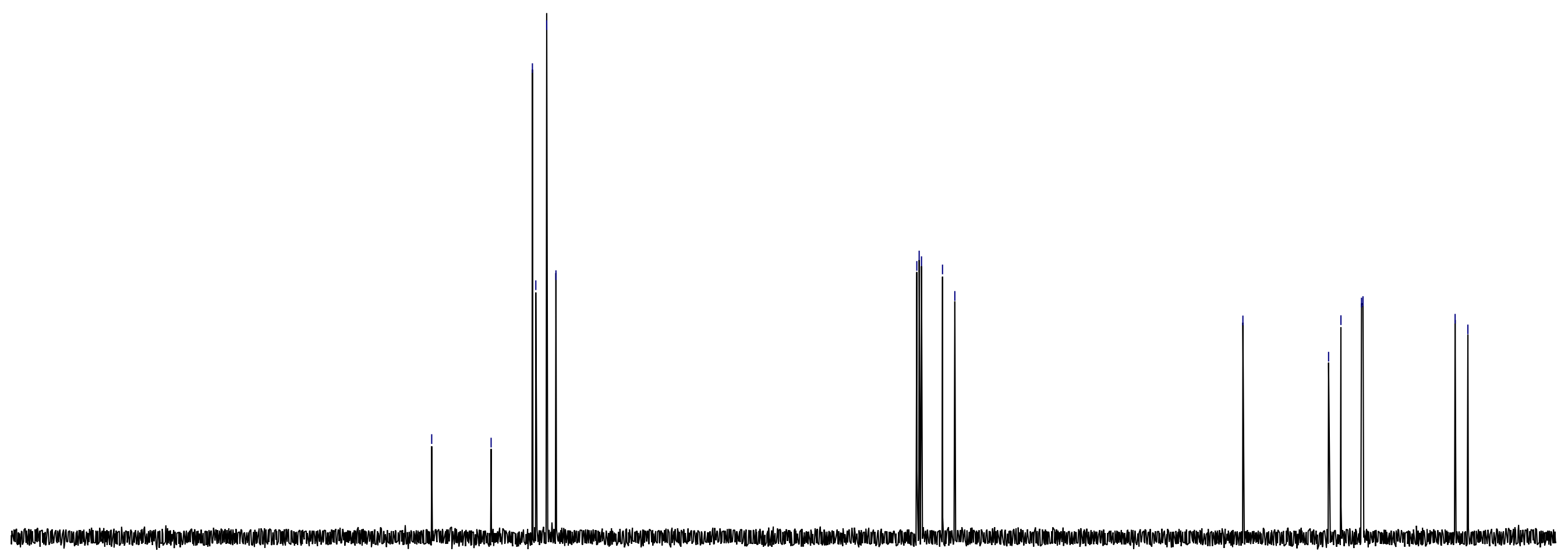

\begin{tabular}{|c|c|c|c|c|c|c|c|c|c|c|c|c|c|c|c|c|c|c|c|c|}
\hline 200 & 190 & 180 & 170 & 160 & 150 & 140 & 130 & 120 & 110 & $\begin{array}{c}100 \\
\text { f1 }\end{array}$ & $\begin{array}{r}90 \\
\text { (ppm) }\end{array}$ & 80 & 70 & 60 & 50 & 40 & 30 & 20 & SI-133 & 0 \\
\hline
\end{tabular}




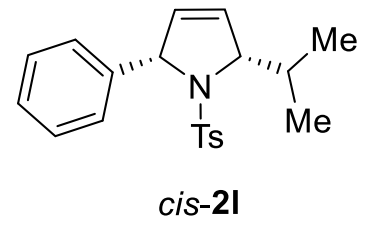

${ }^{1} \mathrm{H}$ NMR, $600 \mathrm{MHz}, \mathrm{CDCl}_{3}$

d.r. $>50 / 1$

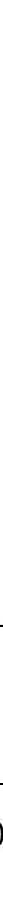




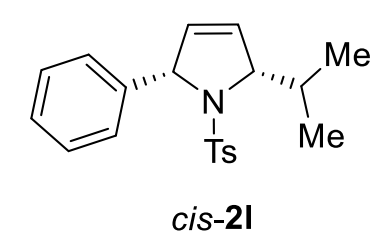

${ }^{13} \mathrm{C} \mathrm{NMR}, 151 \mathrm{MHz}, \mathrm{CDCl}_{3}$

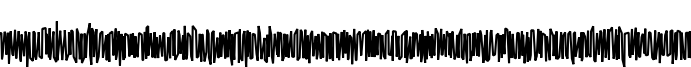

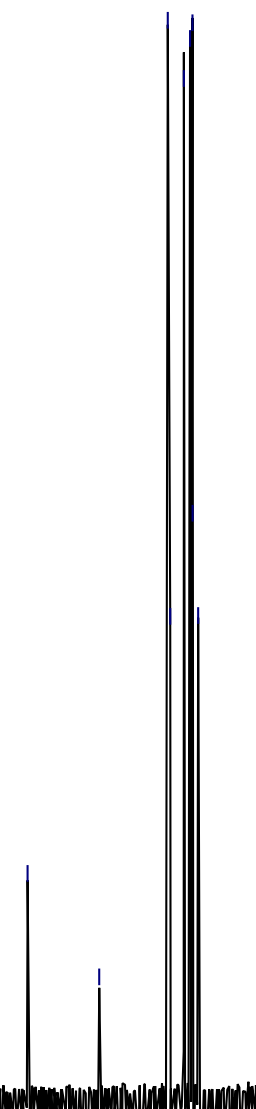




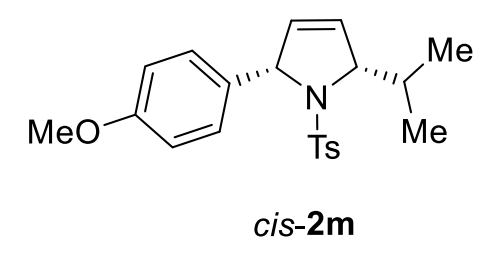

${ }^{1} \mathrm{H} \mathrm{NMR}, 600 \mathrm{MHz}, \mathrm{CDCl}_{3}$

$$
\text { d.r. }>50 / 1
$$

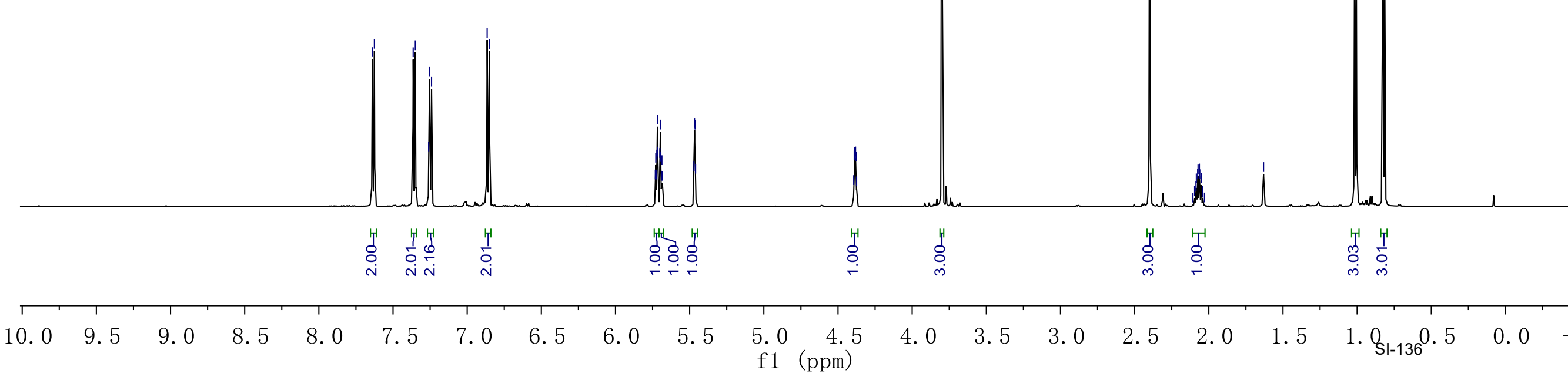




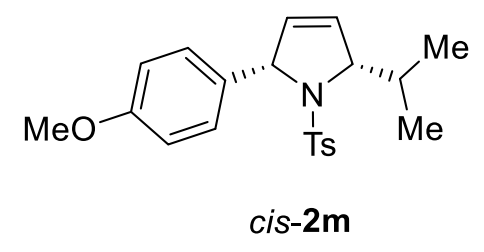

${ }^{13} \mathrm{C} \mathrm{NMR}, 151 \mathrm{MHz}, \mathrm{CDCl}_{3}$

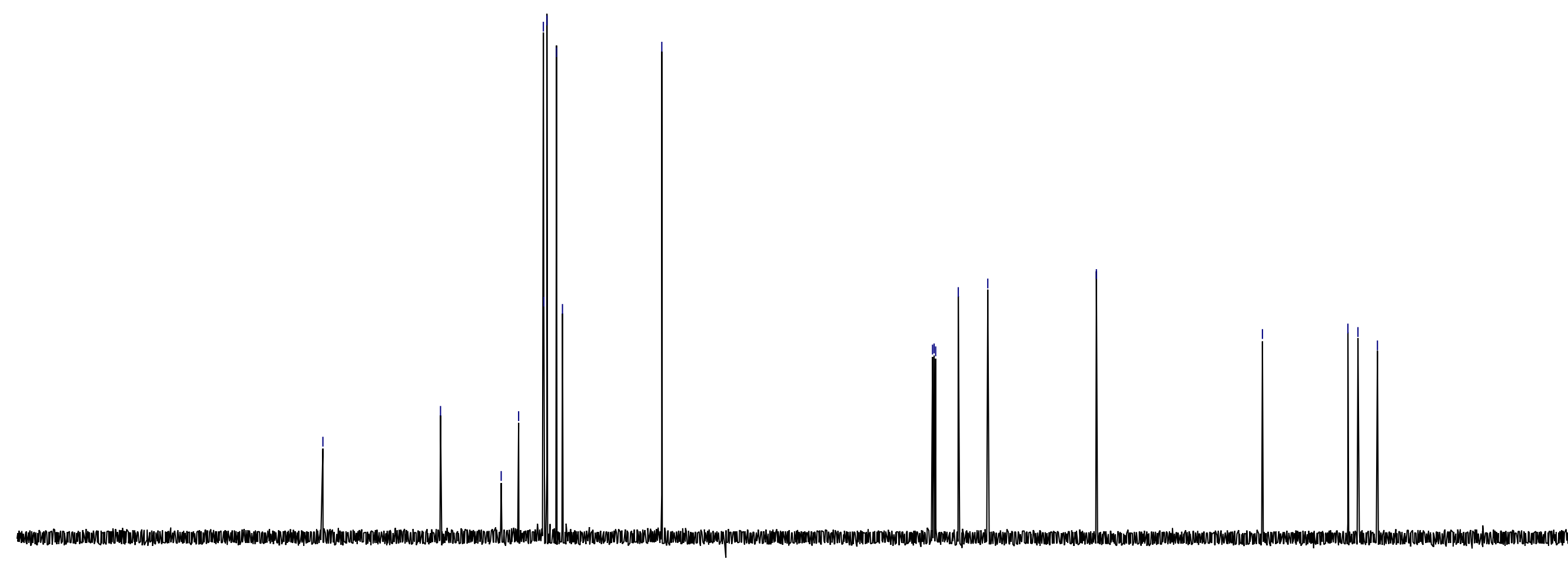

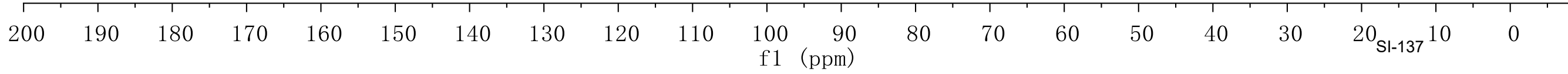




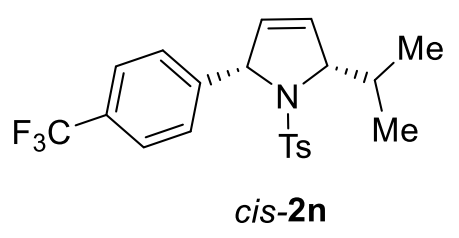

${ }^{1} \mathrm{H}$ NMR, $600 \mathrm{MHz}, \mathrm{CDCl}_{3}$

$$
\text { d.r. }>50 / 1
$$

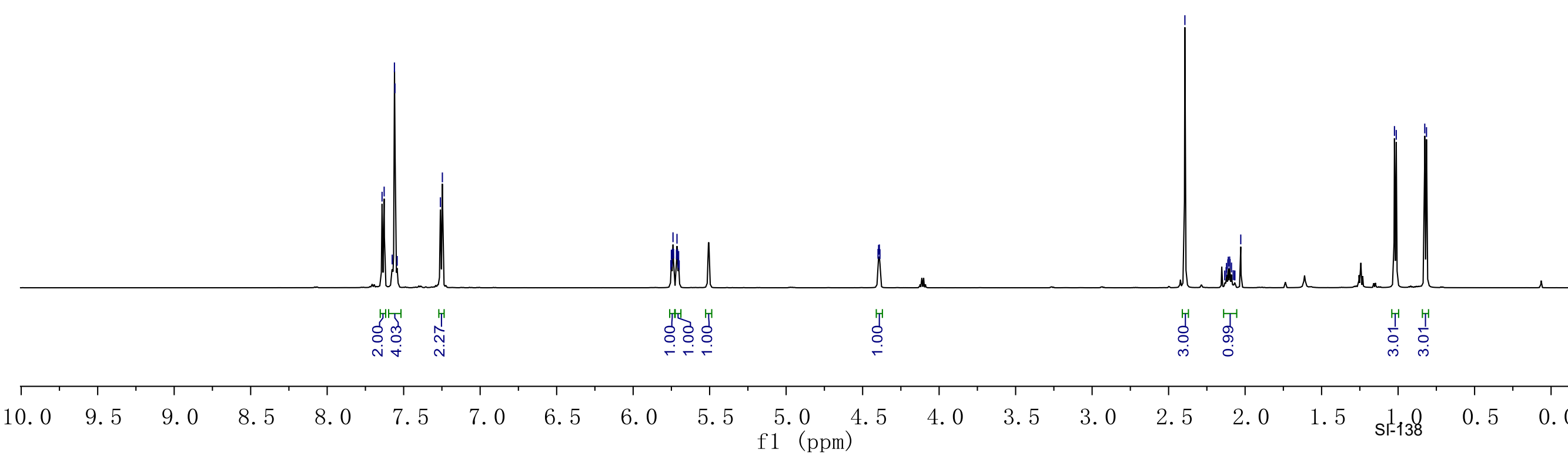




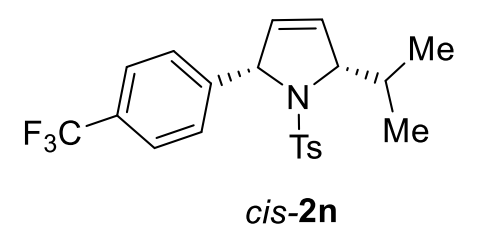

${ }^{13} \mathrm{C} \mathrm{NMR}, 101 \mathrm{MHz}, \mathrm{CDCl}_{3}$

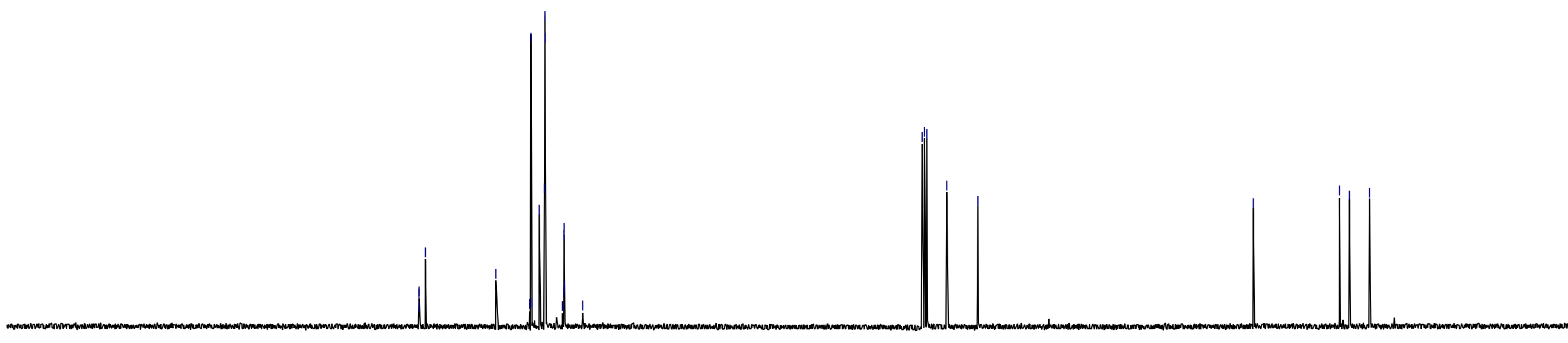

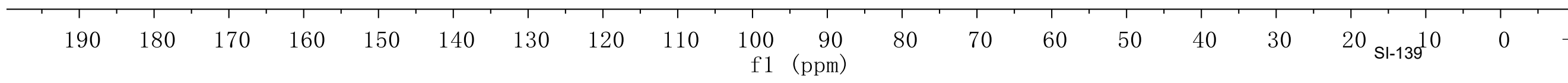




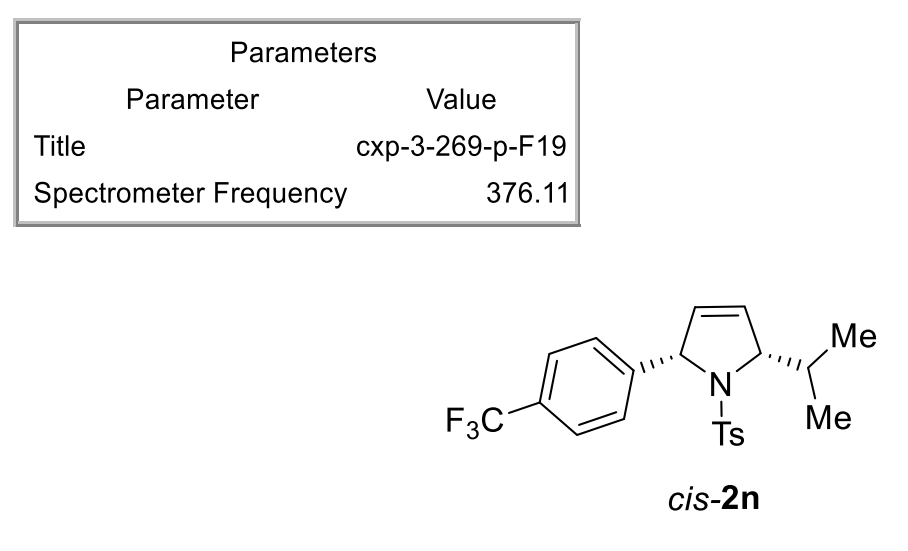

${ }^{19} \mathrm{~F}$ NMR, $377 \mathrm{MHz}, \mathrm{CDCl}_{3}$

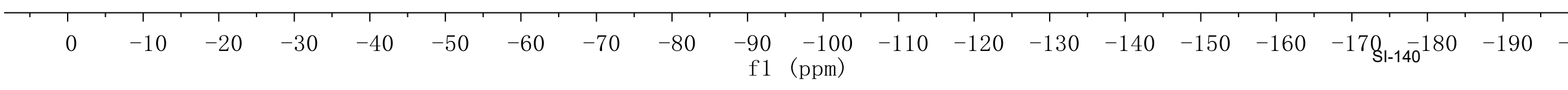




\begin{tabular}{|c|c|}
\hline \multicolumn{2}{|c|}{ Parameters } \\
\hline Parameter & Value \\
\hline Title & cxp-3-275-p-H1 \\
\hline Spectrometer Frequenc & 599.64 \\
\hline
\end{tabular}

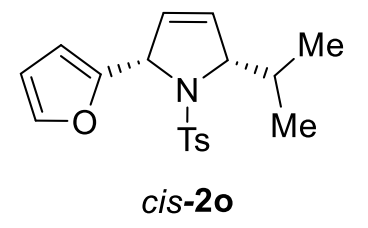

${ }^{1} \mathrm{H}$ NMR, $600 \mathrm{MHz}, \mathrm{CDCl}_{3}$

$$
\text { d.r. }=96 / 4
$$

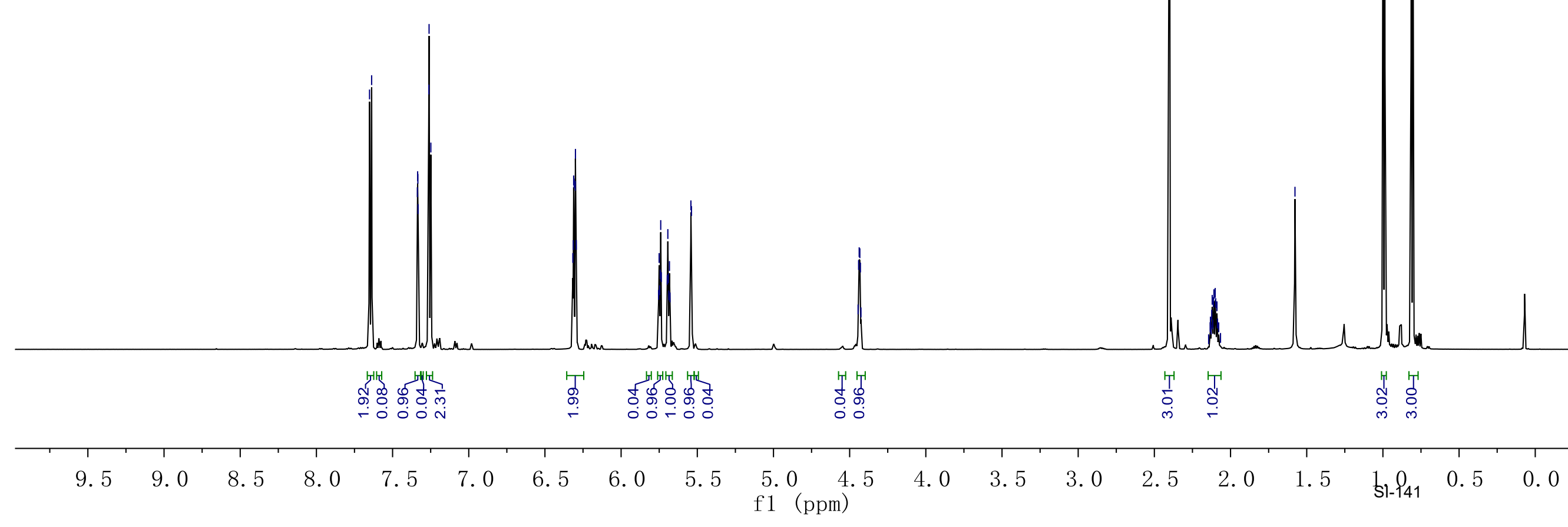




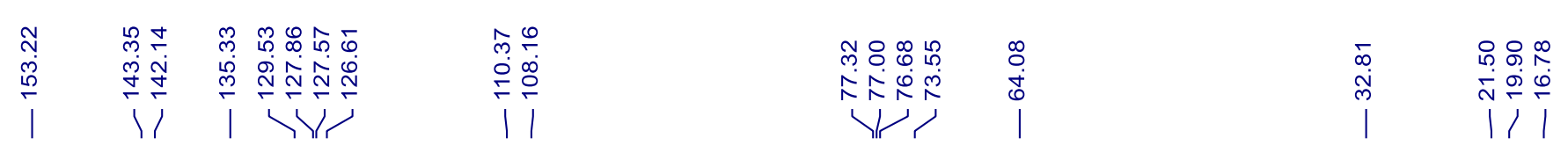

Title cxp-3-275-p-C13

Spectrometer Frequency $\quad 100.53$

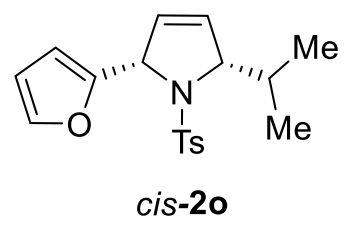

${ }^{13} \mathrm{C}$ NMR, $101 \mathrm{MHz}, \mathrm{CDCl}_{3}$

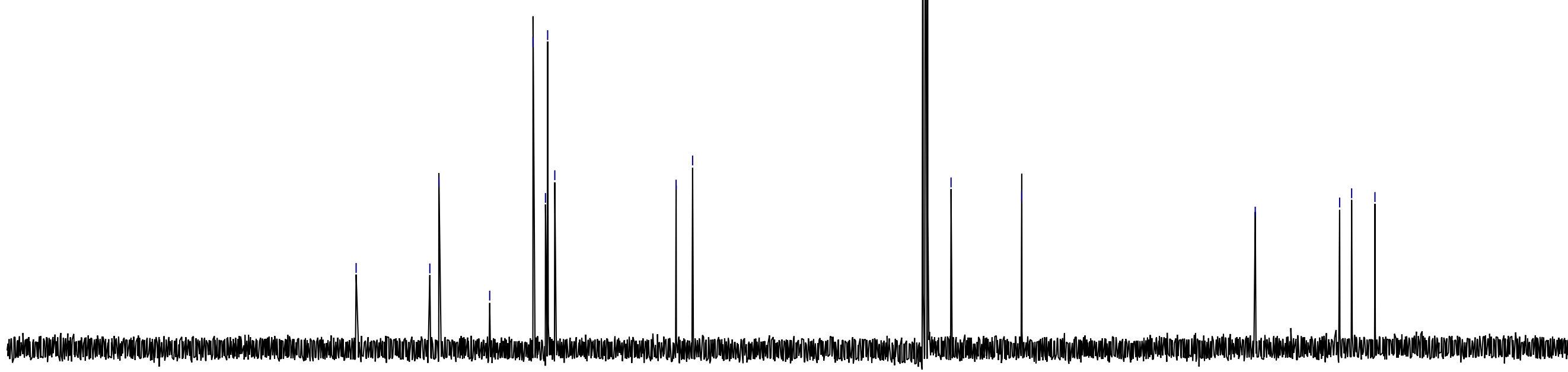




\begin{tabular}{|c|c|}
\hline \multicolumn{2}{|c|}{ Parameters } \\
\hline Parameter & Value \\
\hline Title & cxp-3-276-p-H1 \\
\hline Spectrometer Frequency & 599.64 \\
\hline
\end{tabular}

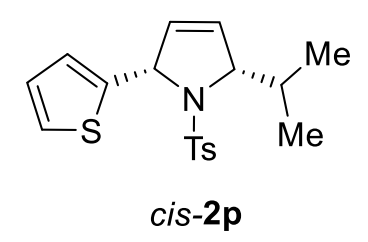

${ }^{1} \mathrm{H}$ NMR, $600 \mathrm{MHz}, \mathrm{CDCl}_{3}$

$$
\text { d.r. }>50 / 1
$$

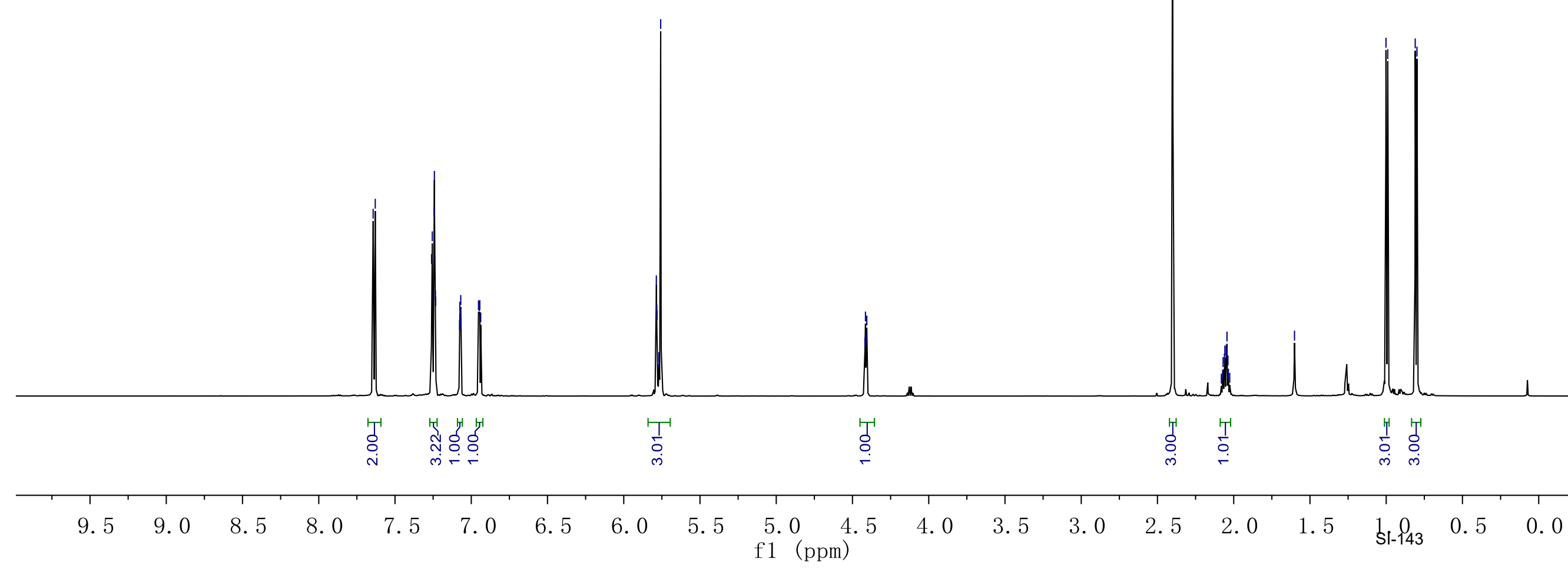




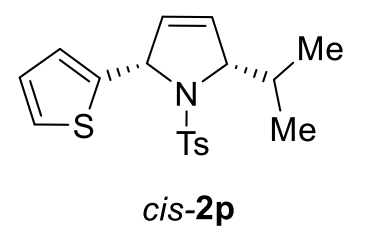

${ }^{13} \mathrm{C} \mathrm{NMR}, 101 \mathrm{MHz}, \mathrm{CDCl}_{3}$

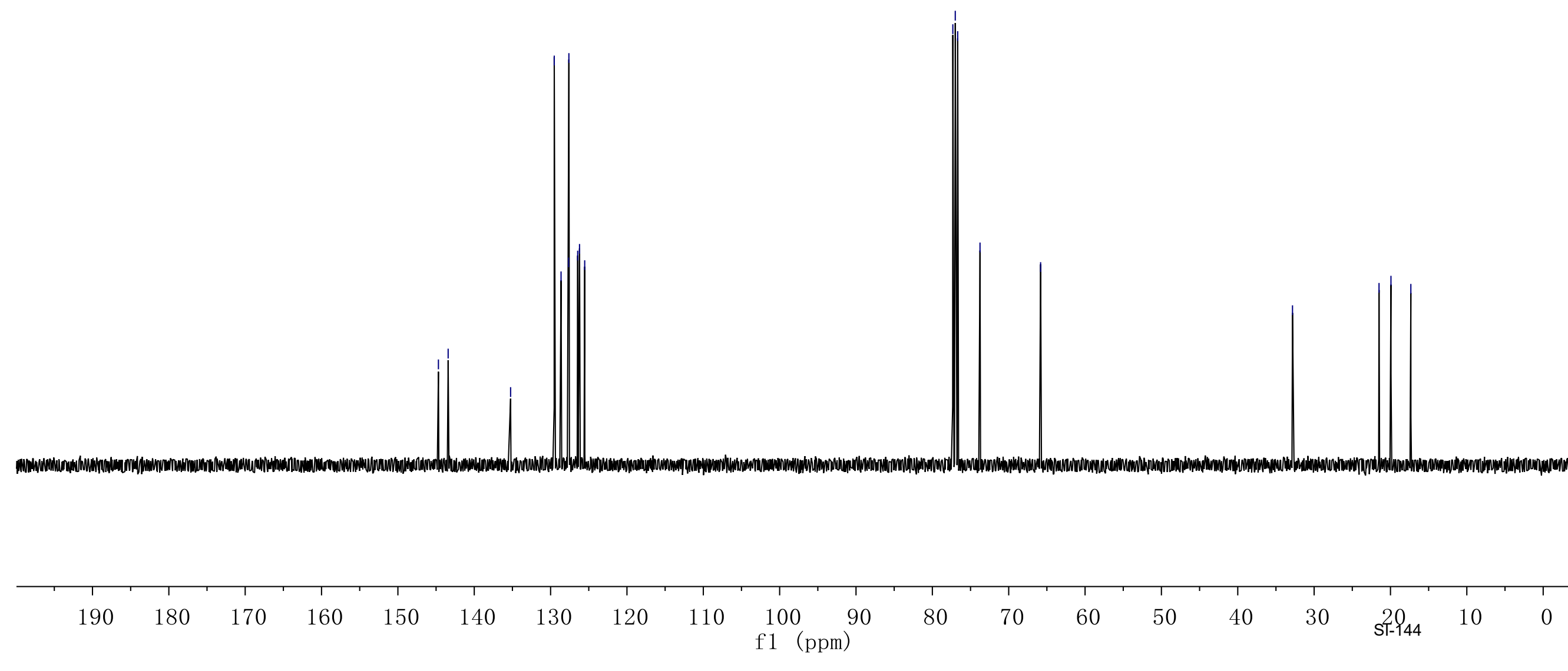




\begin{tabular}{|lr|}
\hline \multicolumn{3}{|c|}{ Parameters } \\
Title & \multicolumn{1}{c|}{ Value } \\
Spectrometer & cxp-4-3-p-H1 \\
\hline
\end{tabular}

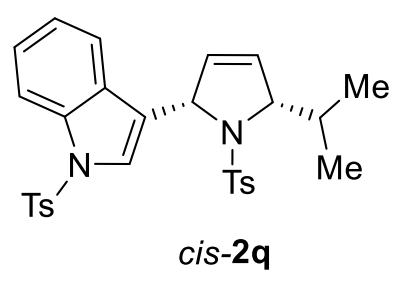

${ }^{1} \mathrm{H}$ NMR, $600 \mathrm{MHz}, \mathrm{CDCl}_{3}$

$$
\text { d.r. }>50 / 1
$$

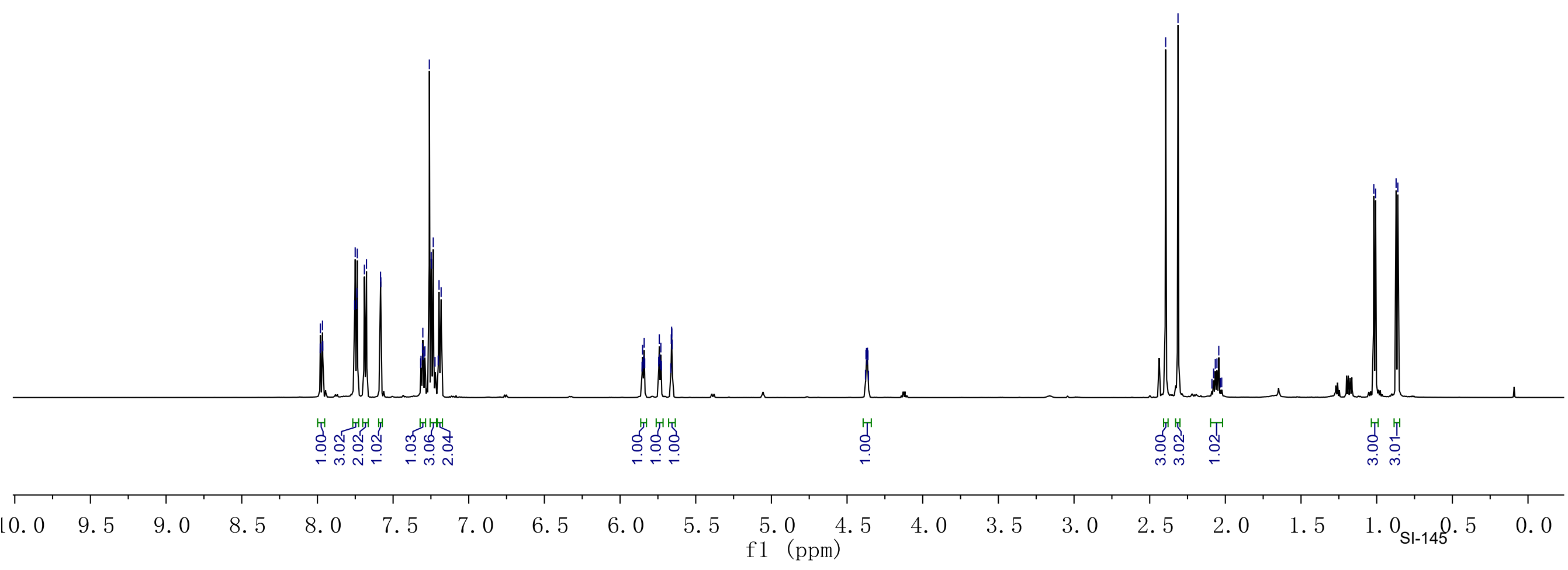




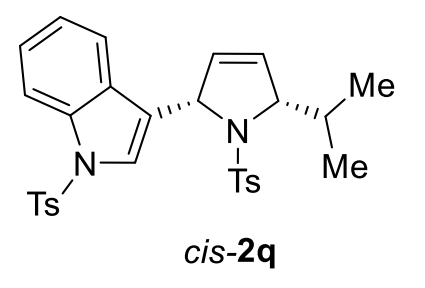

${ }^{13} \mathrm{C}$ NMR, $101 \mathrm{MHz}, \mathrm{CDCl}_{3}$

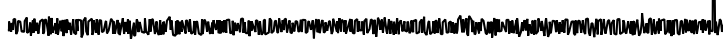

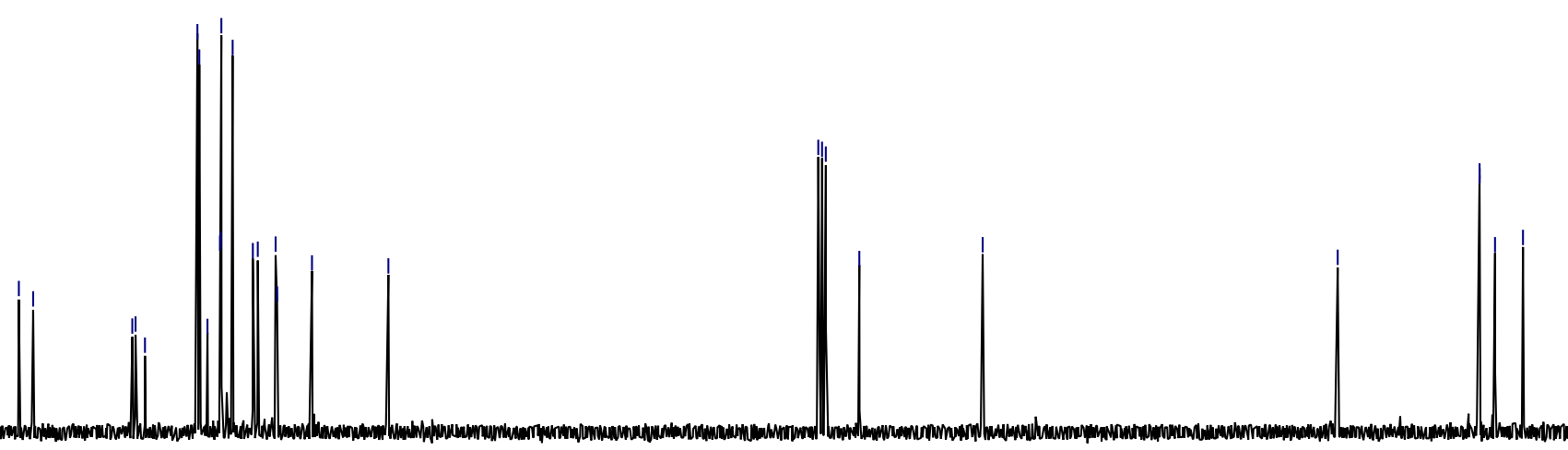

\begin{tabular}{lllllllllllllllll}
\hline 190 & 180 & 170 & 160 & 150 & 140 & 130 & 120 & 110 & $\begin{array}{l}100 \\
\mathrm{f} 1\end{array}$ (ppm) & 90 & 70 & 60 & 50 & 40 & 30 & 20
\end{tabular}




\begin{tabular}{|c|c|}
\hline \multicolumn{2}{|c|}{ Parameters } \\
\hline Parameter & Value \\
\hline Title & cxp-3-277-p-H1 \\
\hline Spectrometer Frequency & 599.64 \\
\hline
\end{tabular}

$$
\left.\underset{\text { cis-2r }}{\mathrm{Ts}_{\mathrm{T}}}\right\rangle_{\mathrm{Me}}^{\mathrm{Me}}
$$

${ }^{1} \mathrm{H} \mathrm{NMR}, 600 \mathrm{MHz}, \mathrm{CDCl}_{3}$

$$
\text { d.r. }>50 / 1
$$

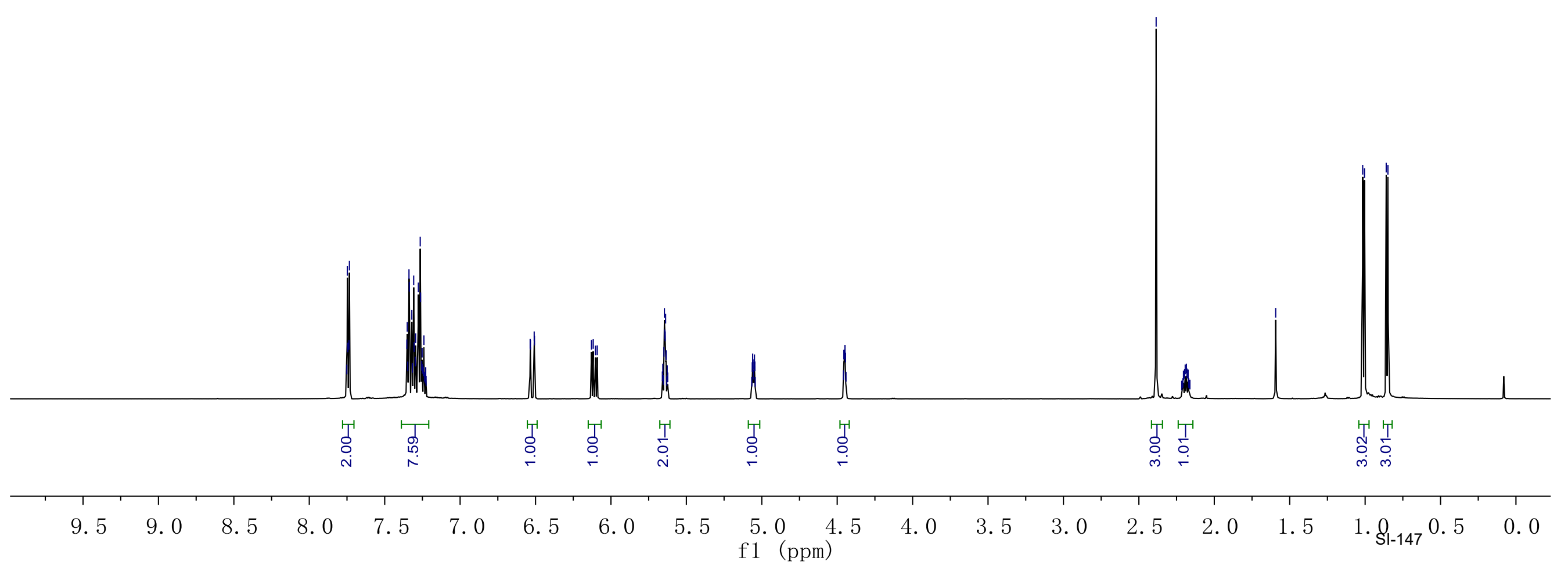


Spectrometer Frequency 100.53

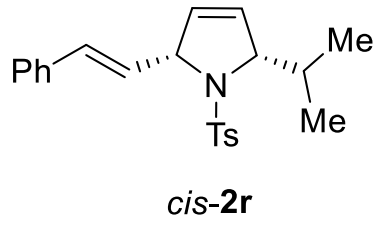

${ }^{13} \mathrm{C} \mathrm{NMR}, 101 \mathrm{MHz}, \mathrm{CDCl}_{3}$

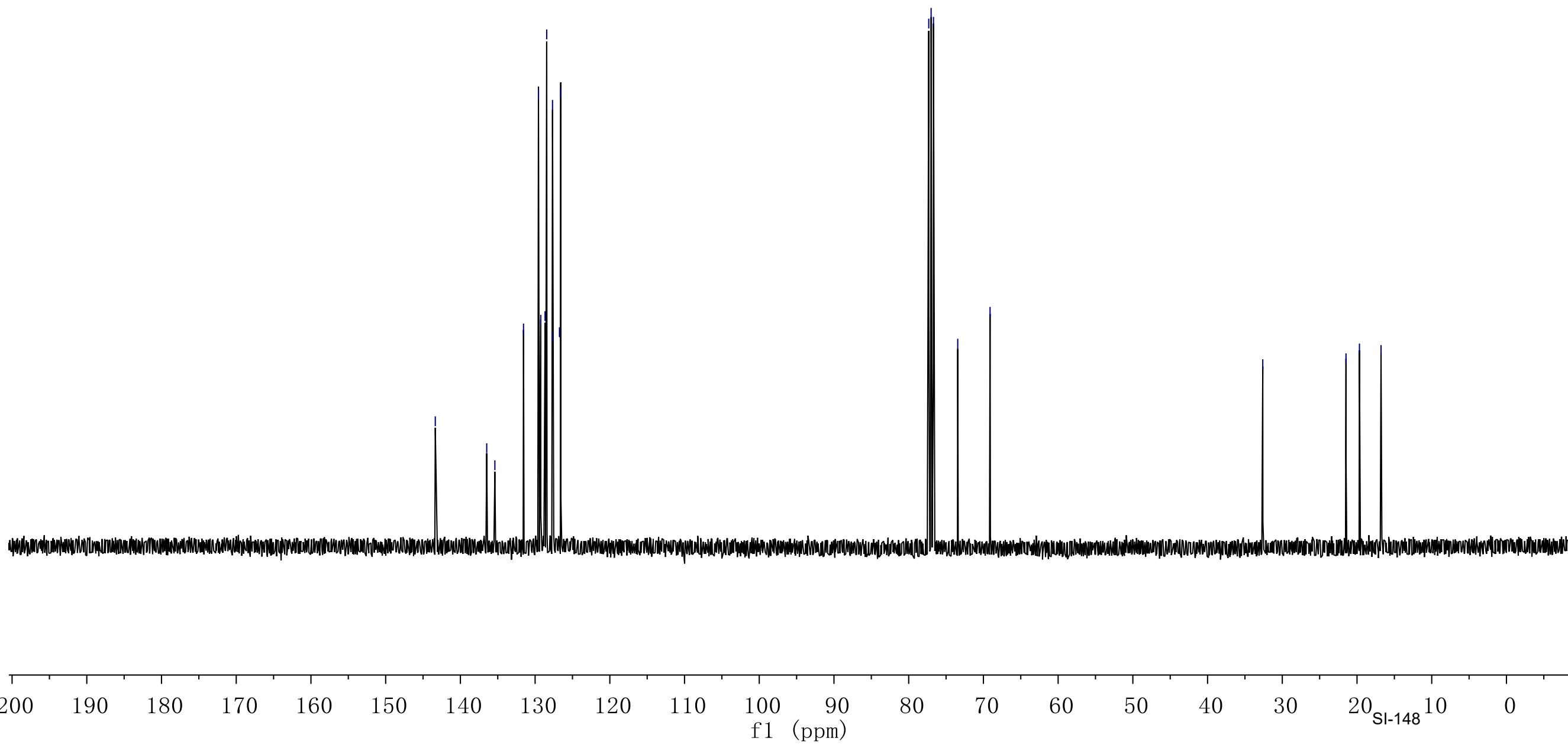




\begin{tabular}{|lr|}
\hline \multicolumn{2}{|c|}{ Parameters } \\
\multicolumn{3}{|c|}{ Parameter } & \multicolumn{1}{c|}{ Value } \\
Title & cxp-4-165-p-H1 \\
Solvent & cdcl3 \\
Spectrometer Frequency & 599.64 \\
\hline
\end{tabular}

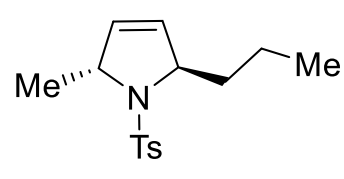

trans-2a

${ }^{1} \mathrm{H} \mathrm{NMR}, 500 \mathrm{MHz}, \mathrm{CDCl}_{3}$

d.r. $=92 / 8$

8. 0

7. 5

7. 0

6. 5

6. 0

5. 5 f1 (ppm)

3. 5

3.
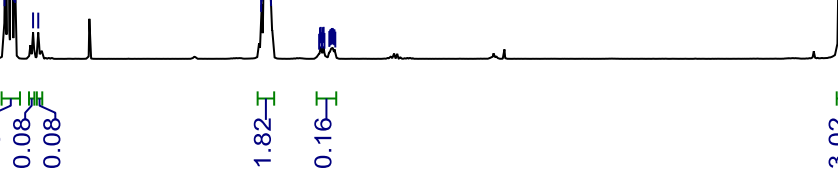

\section{离}

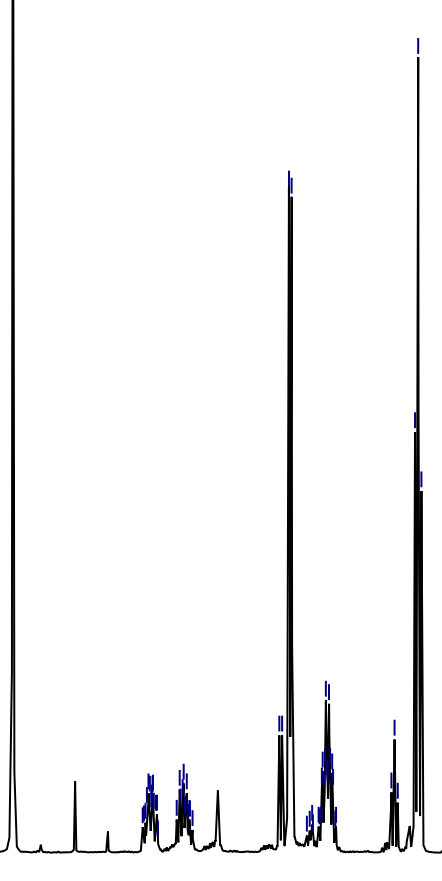

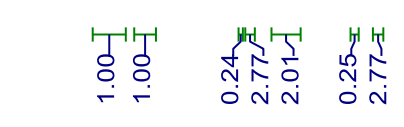




\begin{tabular}{|c|c|c|c|c|c|c|c|}
\hline \multicolumn{2}{|c|}{ Parameters } & 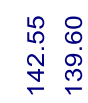 & 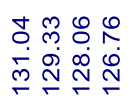 & 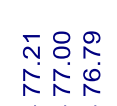 & 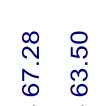 & $\begin{array}{l}g \\
\dot{g} \\
0 \\
e\end{array}$ & 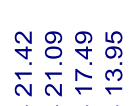 \\
\hline Parameter & Value & & $111 \%$ & 4 & | 1 & i & $1 / 1$ \\
\hline Title & cxp-4-165-p-C13-1 & & & & & & \\
\hline Solvent & $\mathrm{cdcl} 3$ & & & & & & \\
\hline Spectrometer Frequenc & 150.79 & & & & & & \\
\hline
\end{tabular}

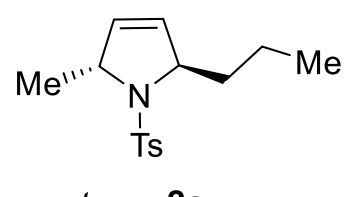

trans-2a

${ }^{13} \mathrm{C} \mathrm{NMR,} 151 \mathrm{MHz}, \mathrm{CDCl}_{3}$

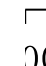

00

190

$180 \quad 170$

160

150

140

$130 \quad 120$

110

100

f1 (ppm)
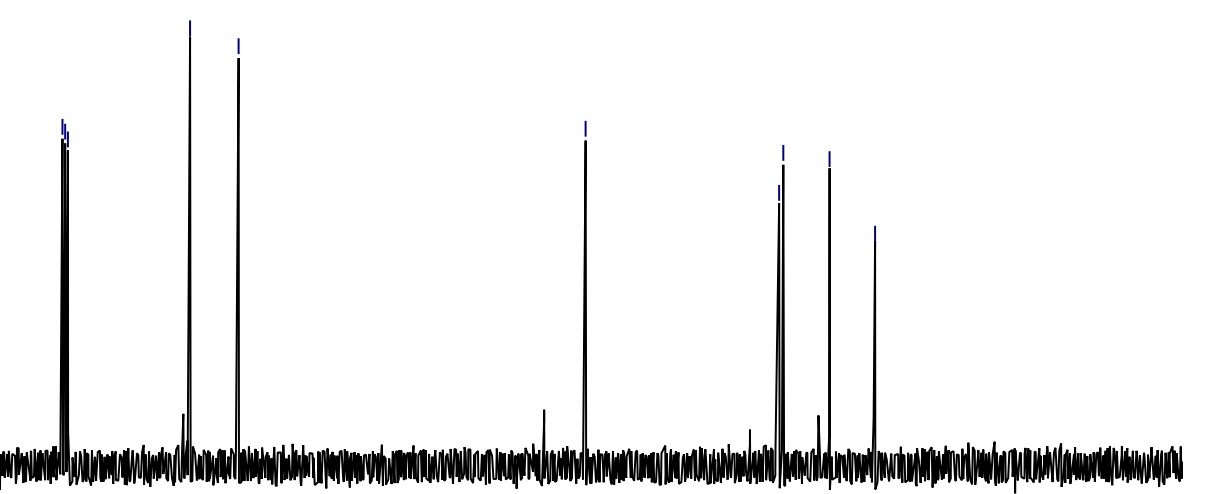


\begin{tabular}{|ll|}
\hline \multicolumn{1}{|c|}{ Parameter } & \multicolumn{1}{c|}{ Value } \\
Title & cxp-7-89-1-H1 \\
Solvent & cdcl3 \\
Spectrometer Frequency599.64 \\
Nucleus & $1 \mathrm{H}$ \\
\hline
\end{tabular}

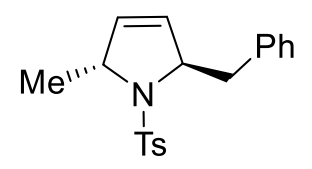

trans-2b

${ }^{1} \mathrm{H}$ NMR, $600 \mathrm{MHz}, \mathrm{CDCl}_{3}$

d.r. $=84 / 16$

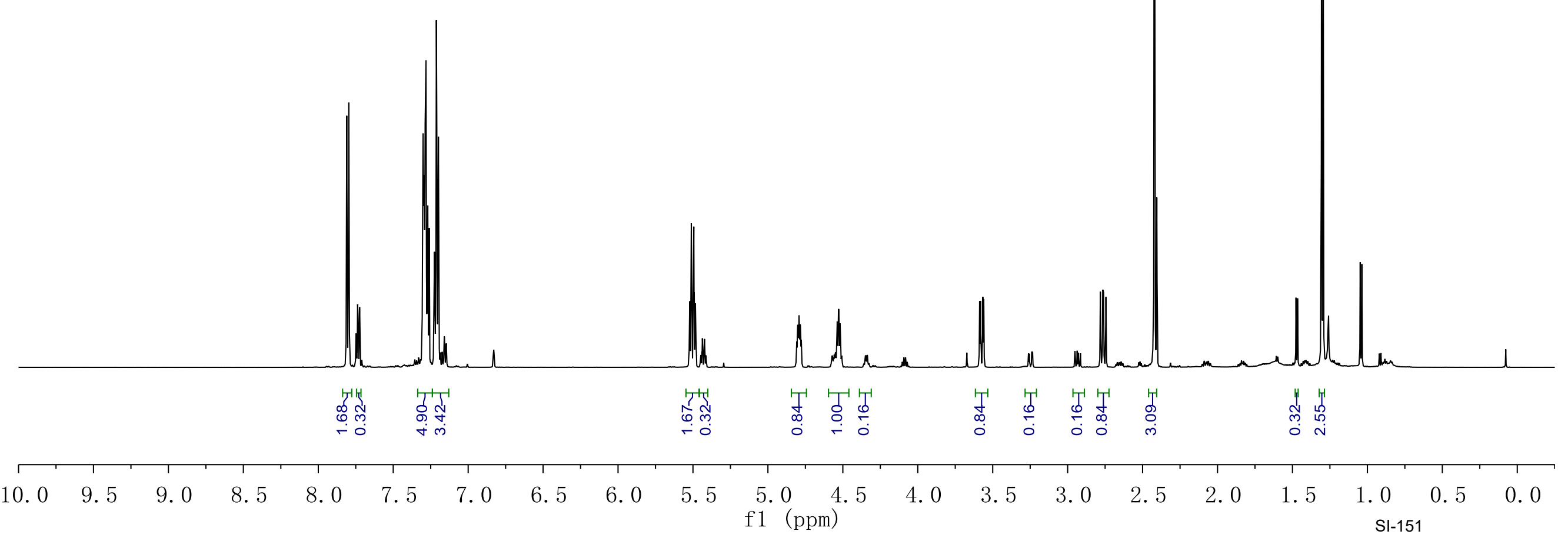




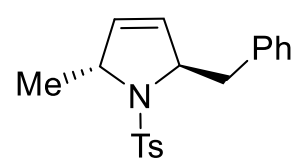

trans-2b

${ }^{13} \mathrm{C} \mathrm{NMR}, 126 \mathrm{MHz}, \mathrm{CDCl}_{3}$

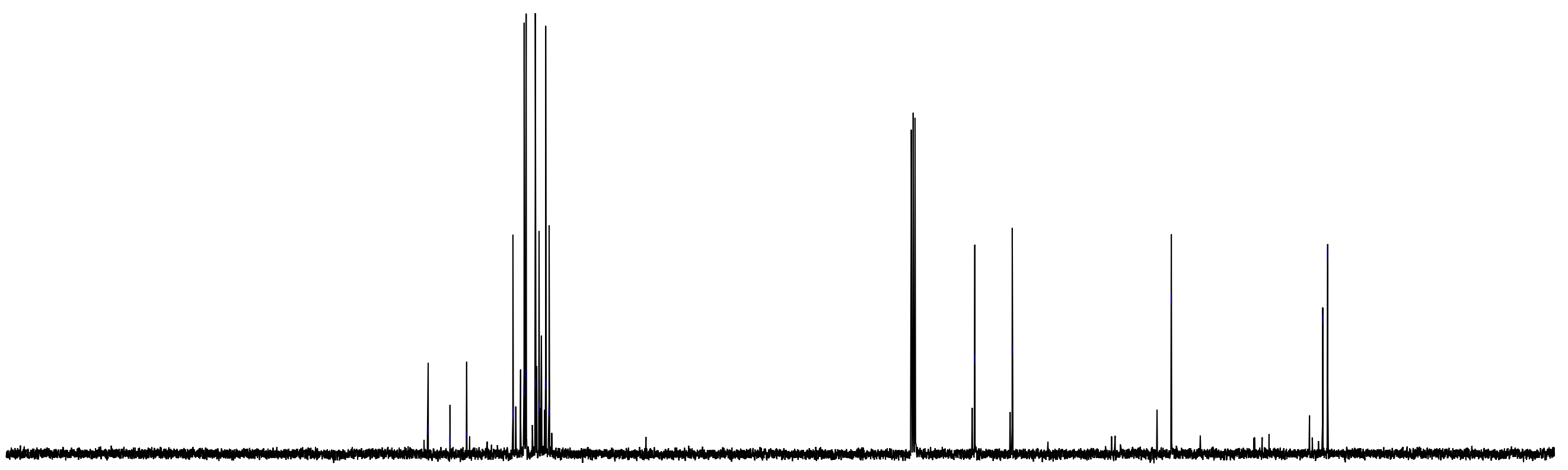

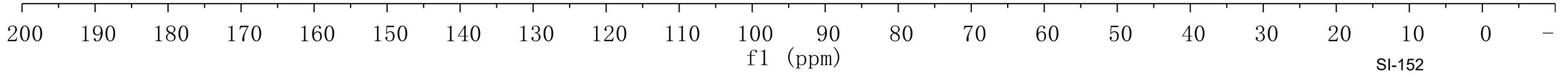




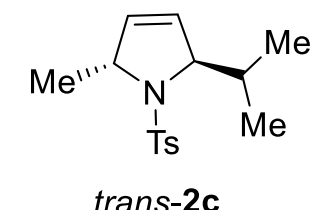

${ }^{1} \mathrm{H} \mathrm{NMR}, 500 \mathrm{MHz}, \mathrm{CDCl}_{3}$

$$
\text { d. } r .=85 / 15
$$

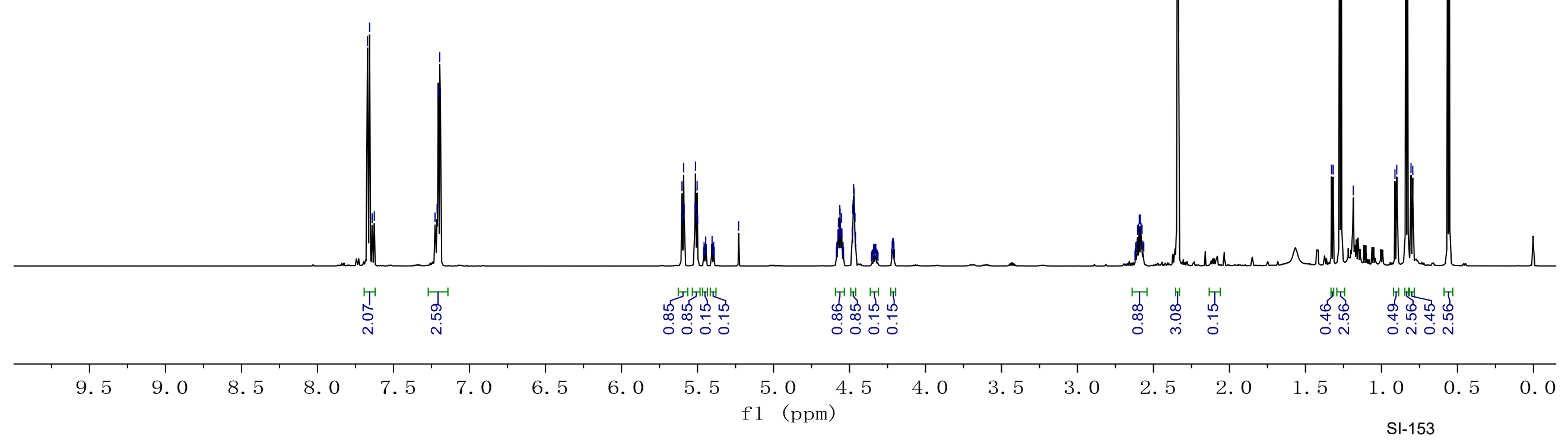




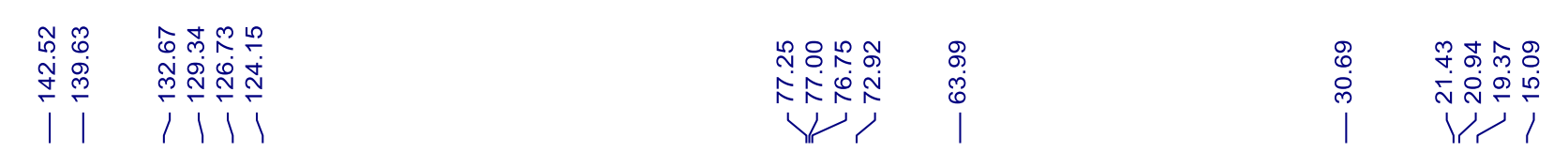

Solvent cdcl3

Spectrometer Frequency 125.70

Nucleus $13 \mathrm{C}$
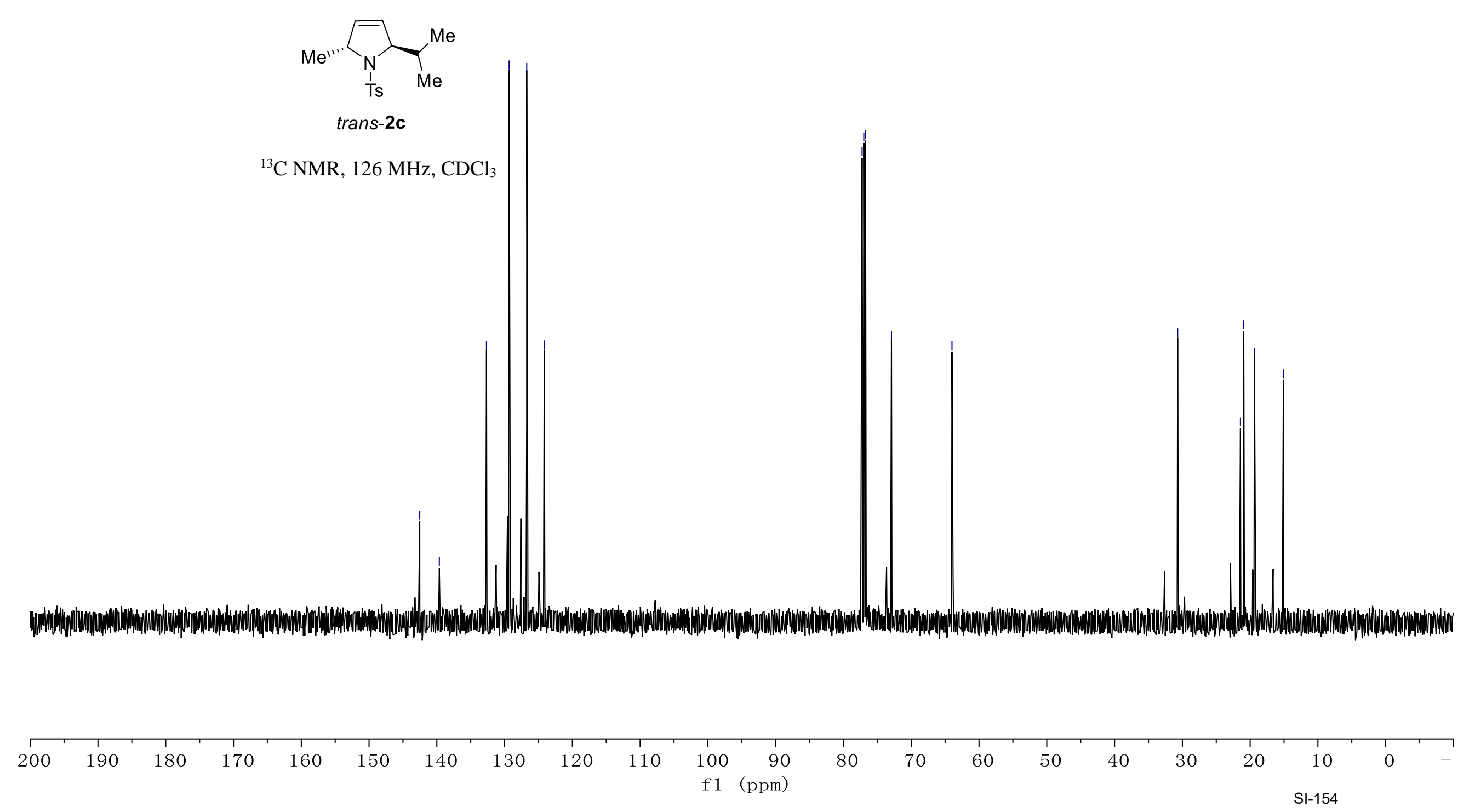


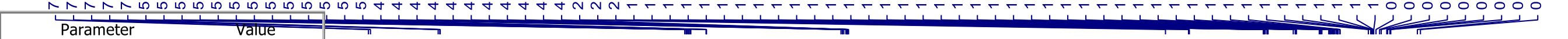
Title Solvent cxp-7-109-p-2-H1

Spectrometer Frequency

Nucleus $1 \mathrm{H}$

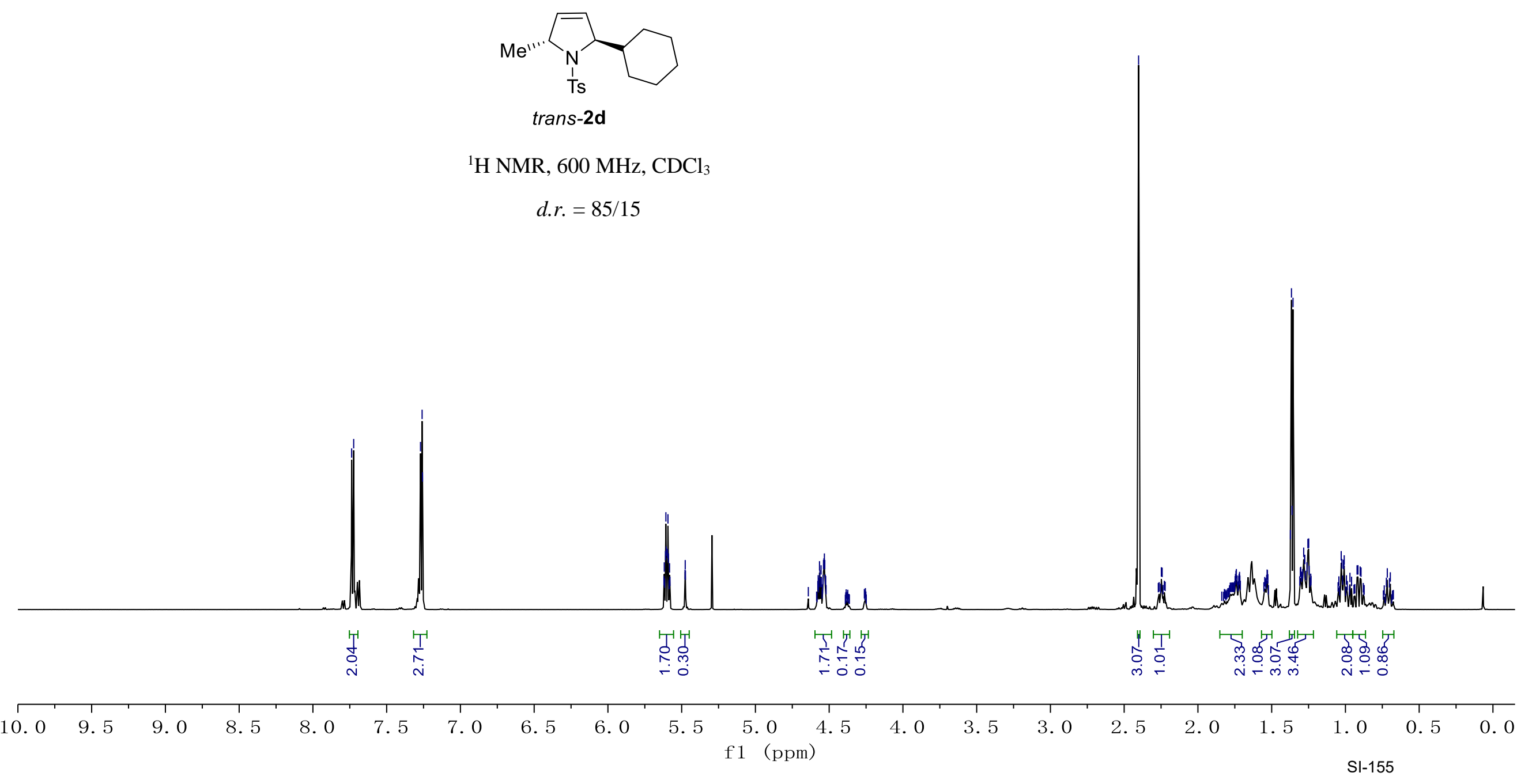




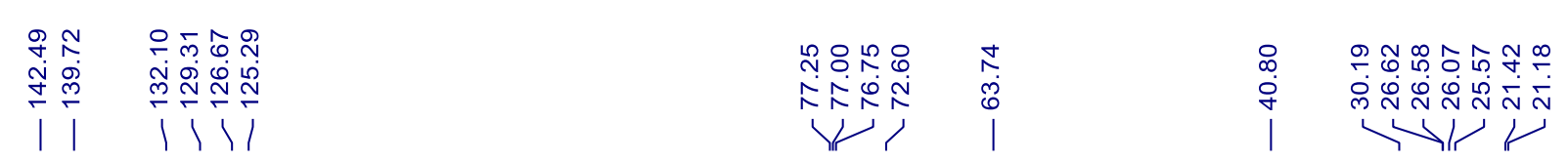

Solvent $\quad$ cdcl3

Spectrometer Frequency 125.70

Nucleus $13 \mathrm{C}$

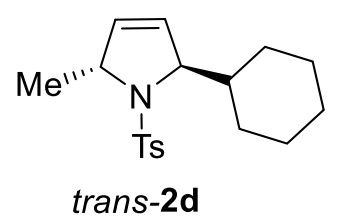

${ }^{13} \mathrm{C} \mathrm{NMR}, 126 \mathrm{MHz}, \mathrm{CDCl}_{3}$

$$
\text { d.r. }=85 / 15
$$

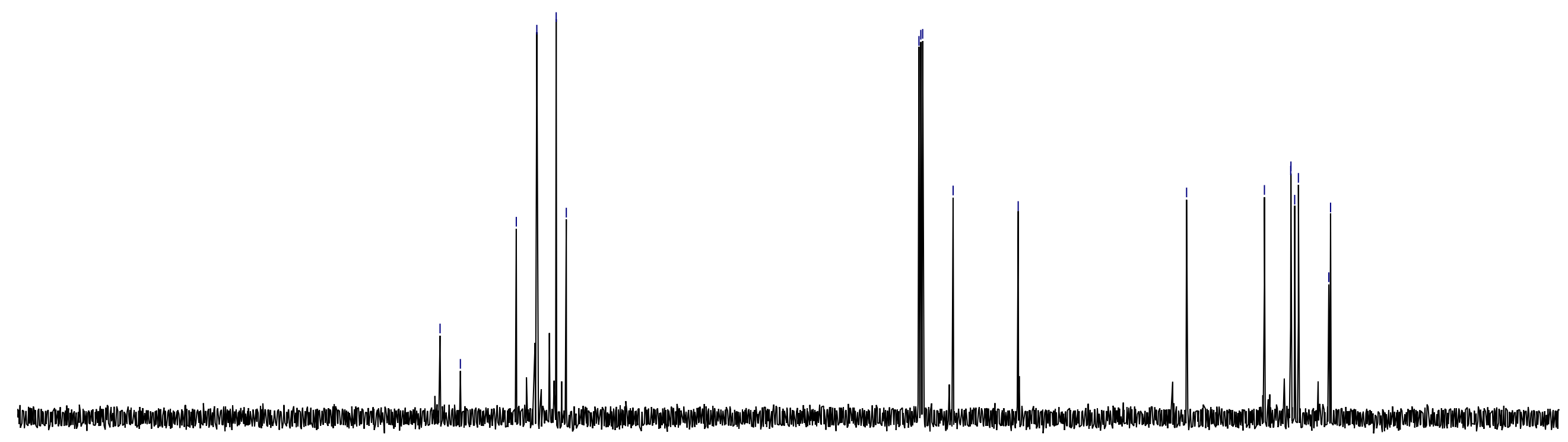

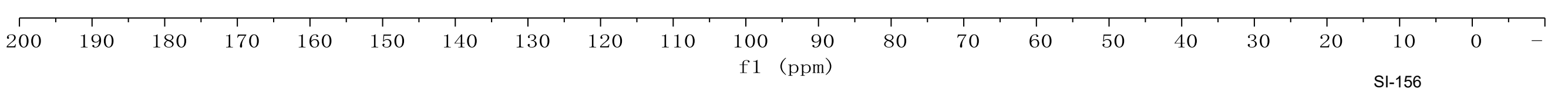




\begin{tabular}{|lc|}
\hline \multicolumn{1}{|c|}{ Parameter } & \multicolumn{1}{c|}{ Value } \\
Title & cxp-7-91-1-p-H1 (1) \\
Solvent & cdcl3 \\
Spectrometer Frequency599.64 & \\
Nucleus & $1 \mathrm{H}$ \\
\hline
\end{tabular}

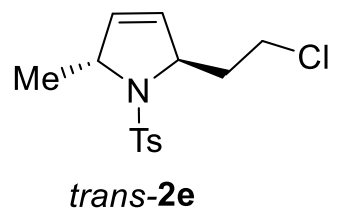

${ }^{1} \mathrm{H} \mathrm{NMR}, 600 \mathrm{MHz}, \mathrm{CDCl}_{3}$

$$
\text { d.r. }=86 / 14
$$

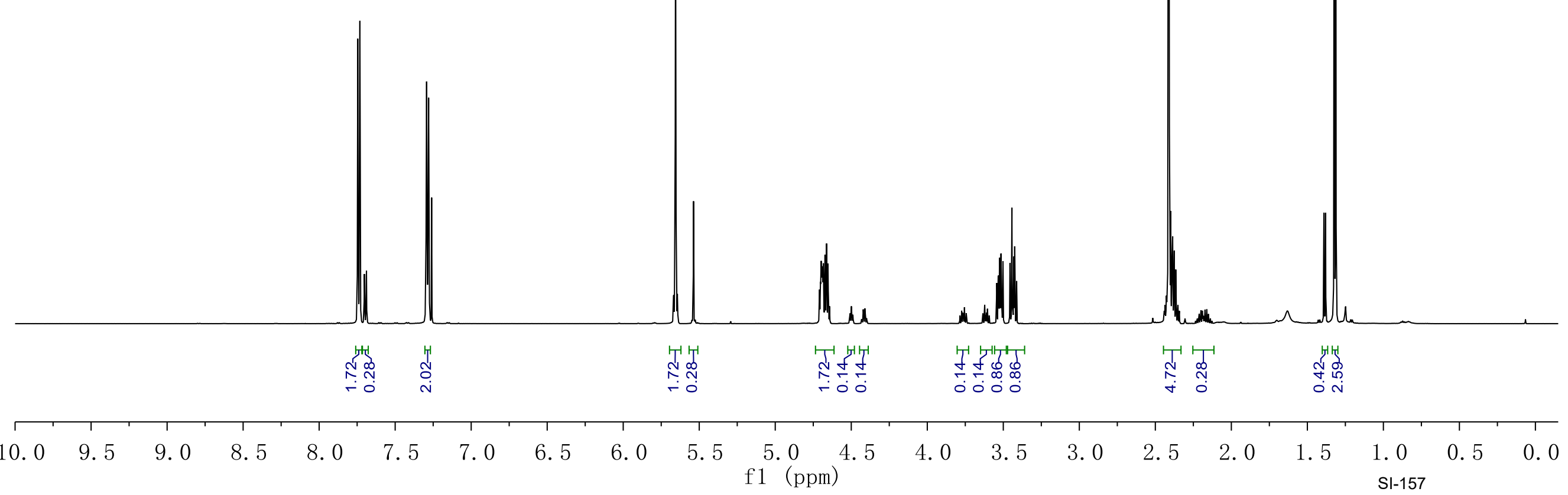




\begin{tabular}{|ll|}
\hline \multicolumn{1}{|c|}{ Parameter } & \multicolumn{1}{c|}{ Value } \\
Title & cxp-7-91-1.1.fid \\
Solvent & CDCl3 \\
Experiment & 1D \\
Spectrometer Frequency125.78
\end{tabular}

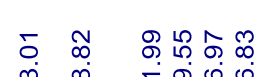

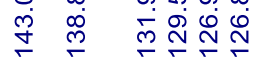

$111 \%$

Spectrometer Frequency125.78

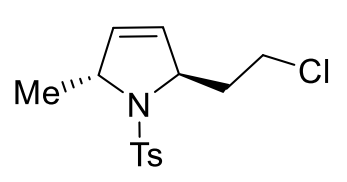

trans-2e

${ }^{13} \mathrm{C} \mathrm{NMR}, 126 \mathrm{MHz}, \mathrm{CDCl}_{3}$

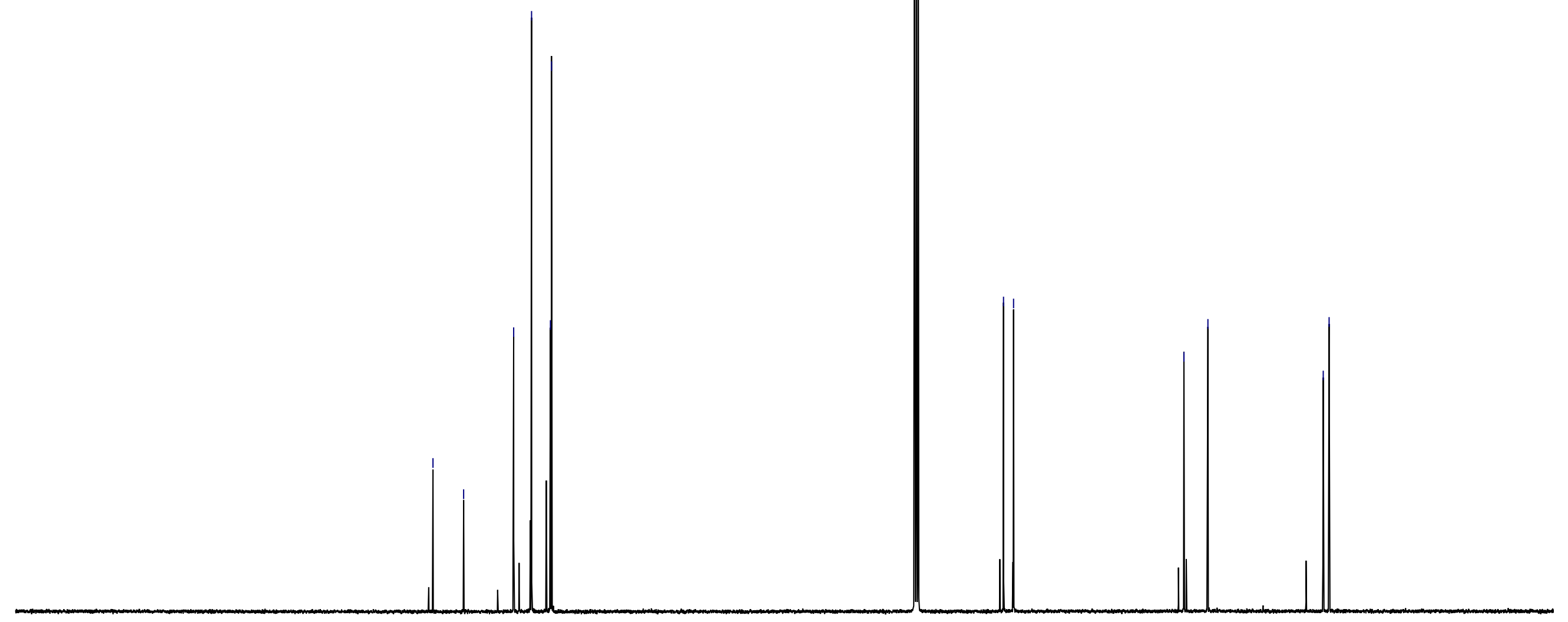

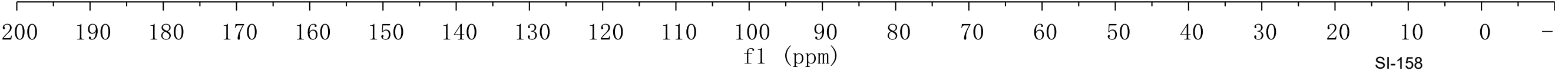




\begin{tabular}{|lr|}
\hline \multicolumn{2}{|c|}{ Parameters } \\
Parameter & \multicolumn{1}{c|}{ Value } \\
Title & cxp-4-135-3-p-H1 \\
Solvent & cdcl3 \\
Spectrometer Frequency & 499.85 \\
\hline
\end{tabular}

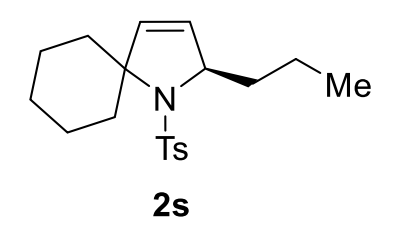

${ }^{1} \mathrm{H} \mathrm{NMR}, 500 \mathrm{MHz}, \mathrm{CDCl}_{3}$

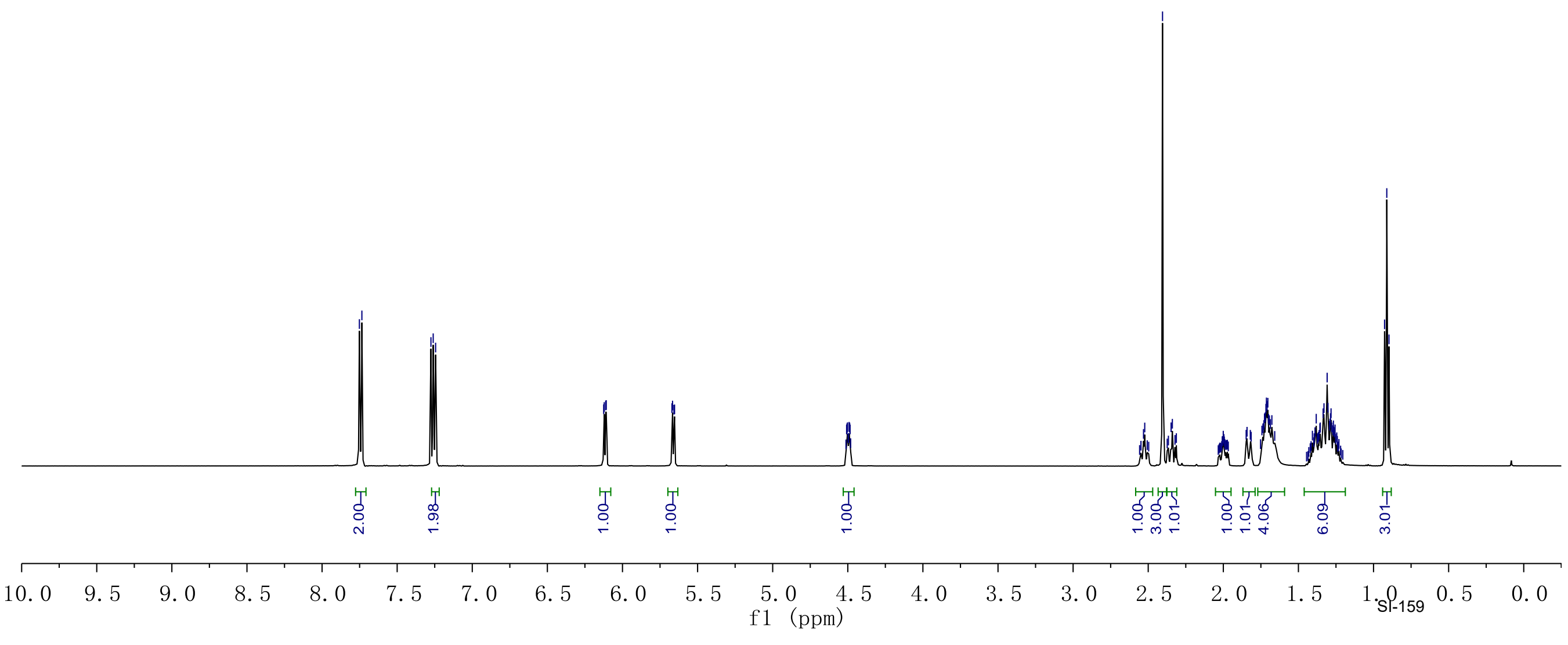




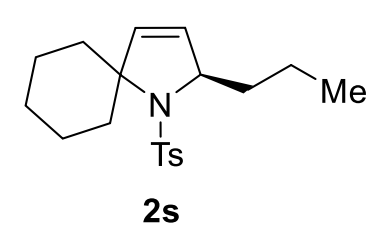

${ }^{13} \mathrm{C} \mathrm{NMR,} 126 \mathrm{MHz}, \mathrm{CDCl}_{3}$
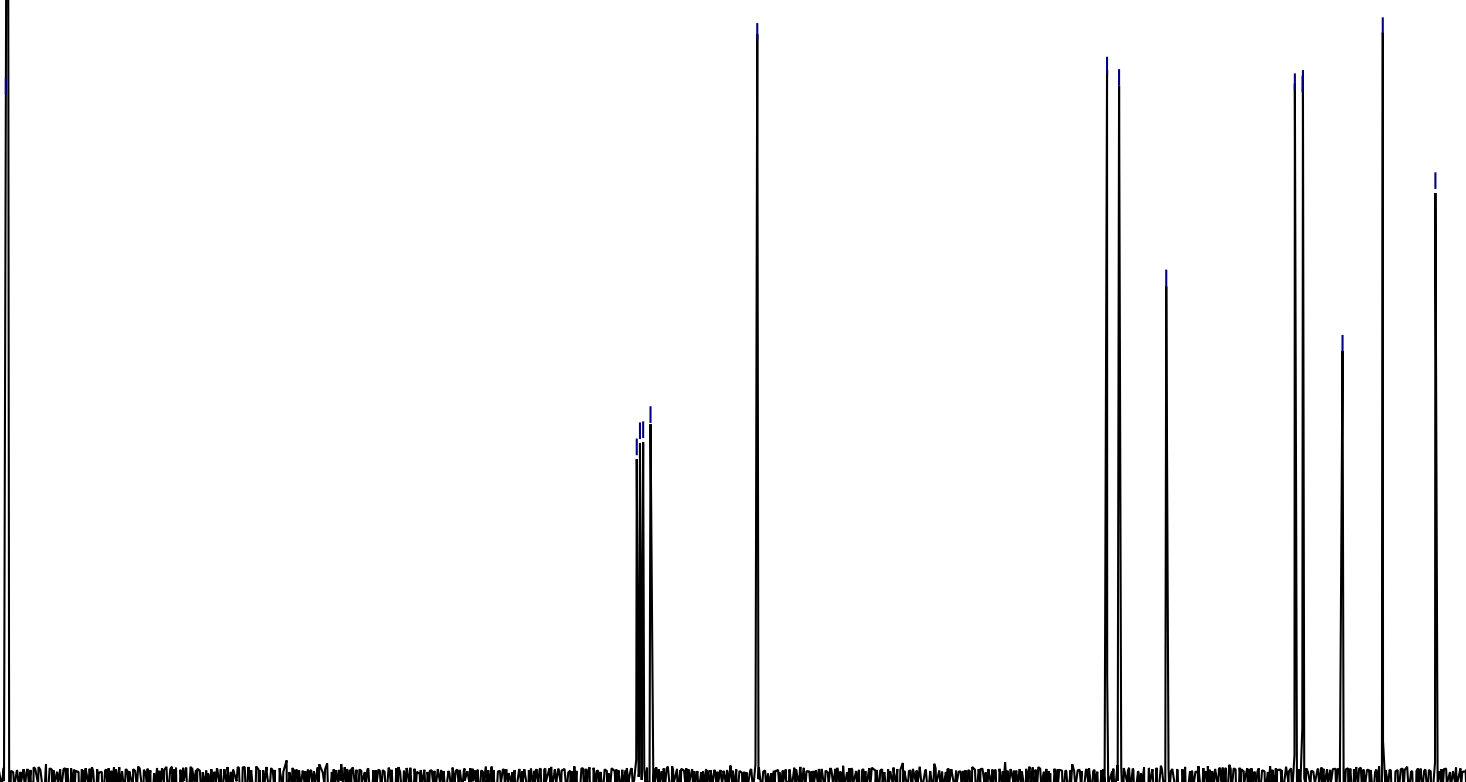

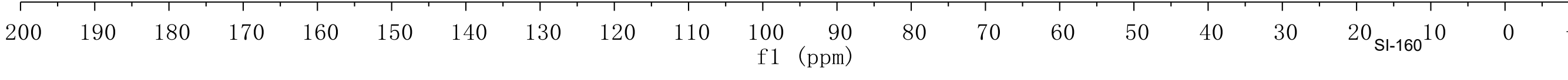


Parameters

Parameter

Title

Value

Spectrometer Frequency $\quad 399.78$

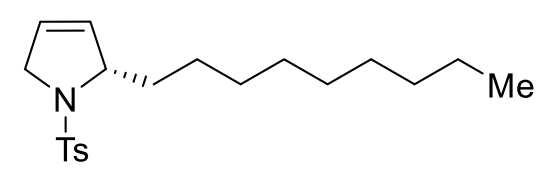

$2 u$

${ }^{1} \mathrm{H} \mathrm{NMR}, 400 \mathrm{MHz}, \mathrm{CDCl}_{3}$

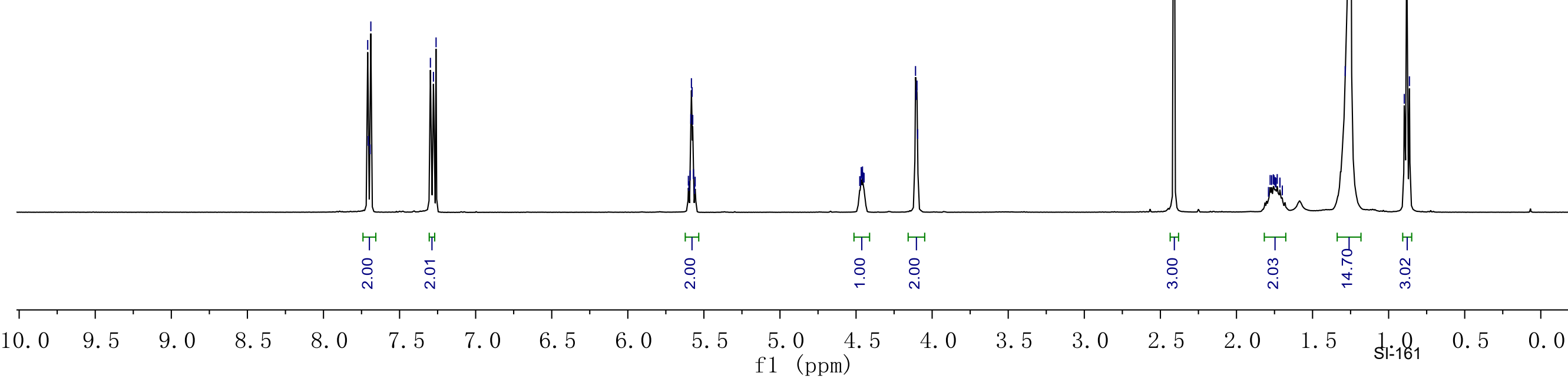




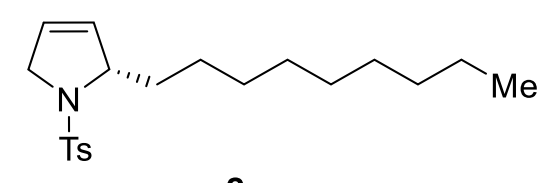

$2 u$

${ }^{13} \mathrm{C} \mathrm{NMR,} 101 \mathrm{MHz}, \mathrm{CDCl}_{3}$

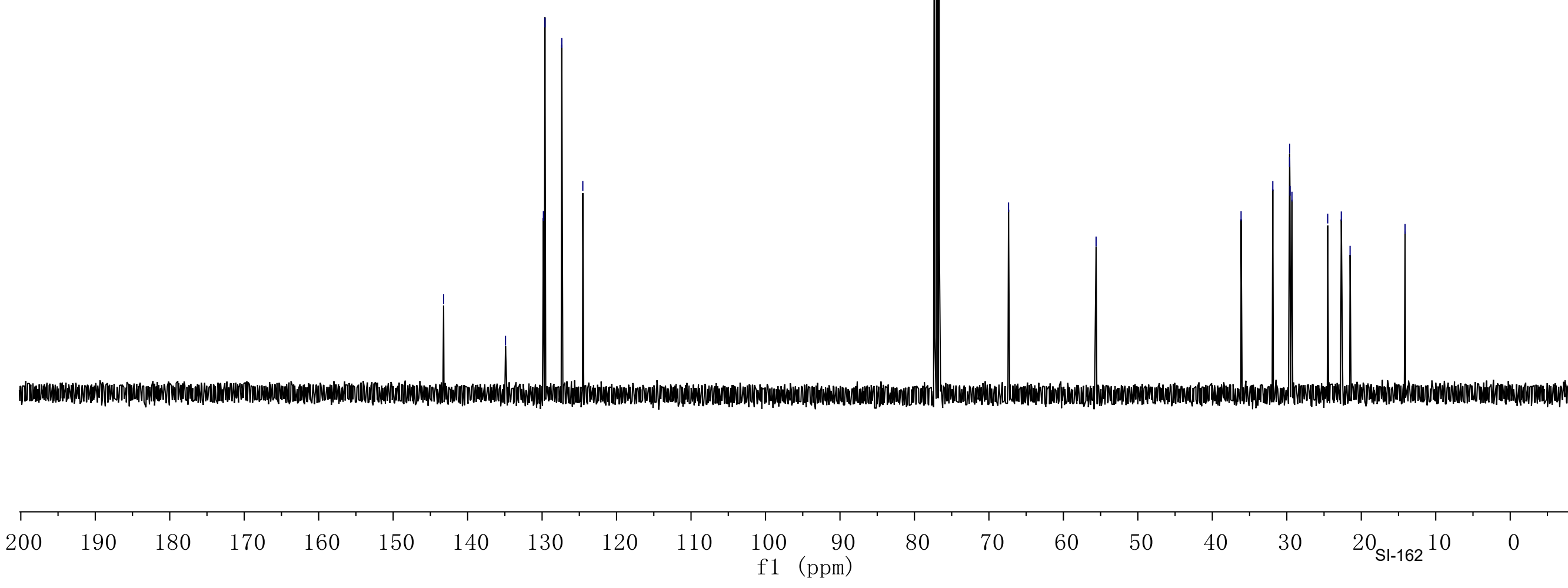




\begin{tabular}{|lr|}
\hline \multicolumn{3}{|c|}{ Parameters } \\
Parameter & \multicolumn{1}{c|}{ Value } \\
Title & cxp-3-270-p-H1 \\
Spectrometer Frequency & 599.64 \\
\hline
\end{tabular}

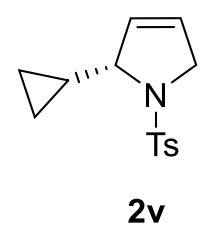

${ }^{1} \mathrm{H} \mathrm{NMR}, 600 \mathrm{MHz}, \mathrm{CDCl}_{3}$

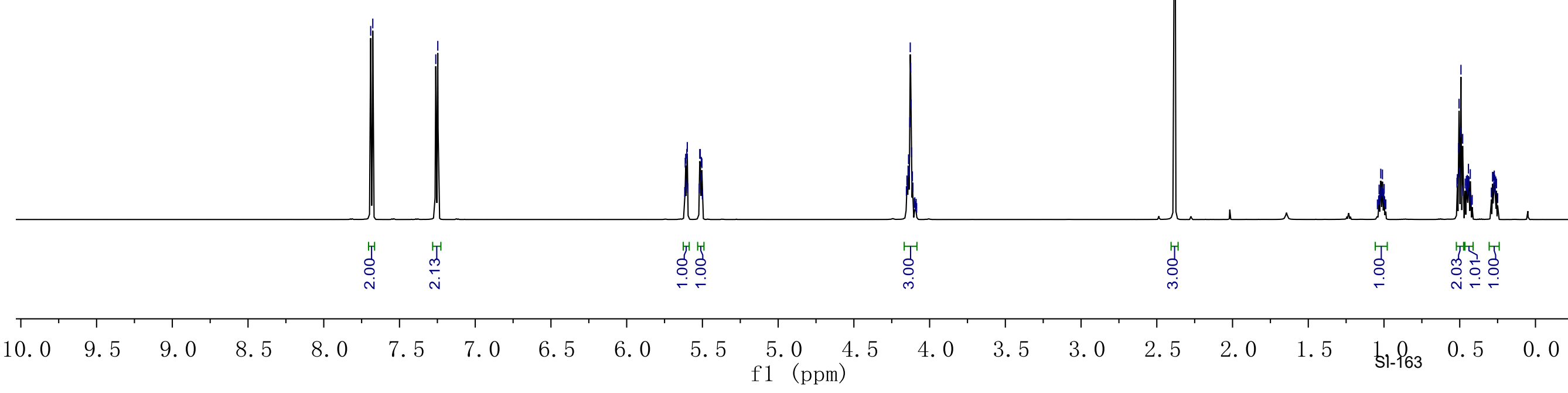




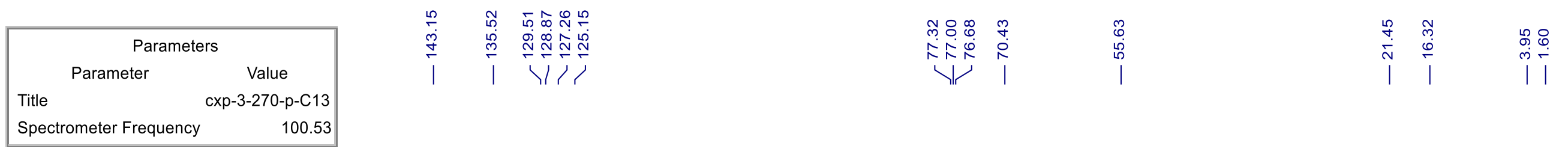

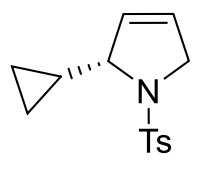

2v

${ }^{13} \mathrm{C} \mathrm{NMR}, 101 \mathrm{MHz}, \mathrm{CDCl}_{3}$

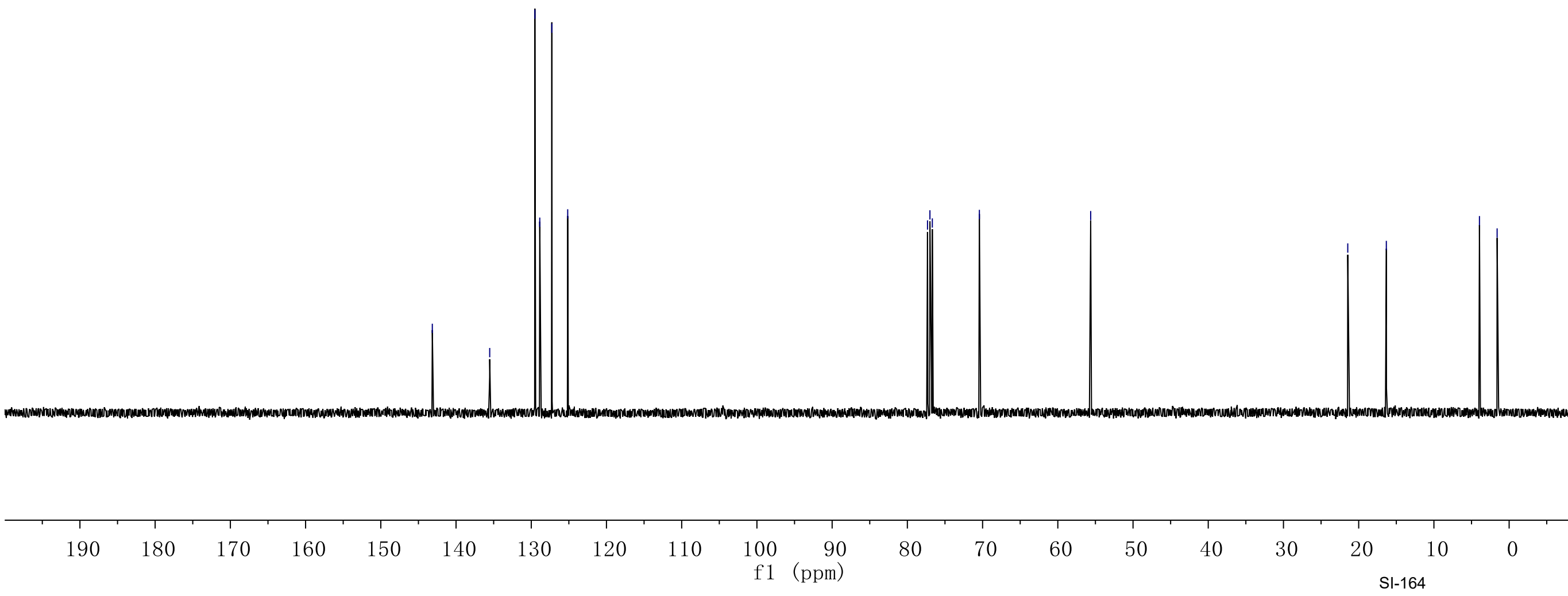




\begin{tabular}{|ll|}
\hline \multicolumn{1}{|c|}{ Parameter } & \multicolumn{1}{c|}{ Value } \\
Title & cxp-6-240-p-H1 \\
Solvent & cdcl3 \\
Spectrometer Frequency & 499.85 \\
Nucleus & $1 \mathrm{H}$ \\
\hline
\end{tabular}

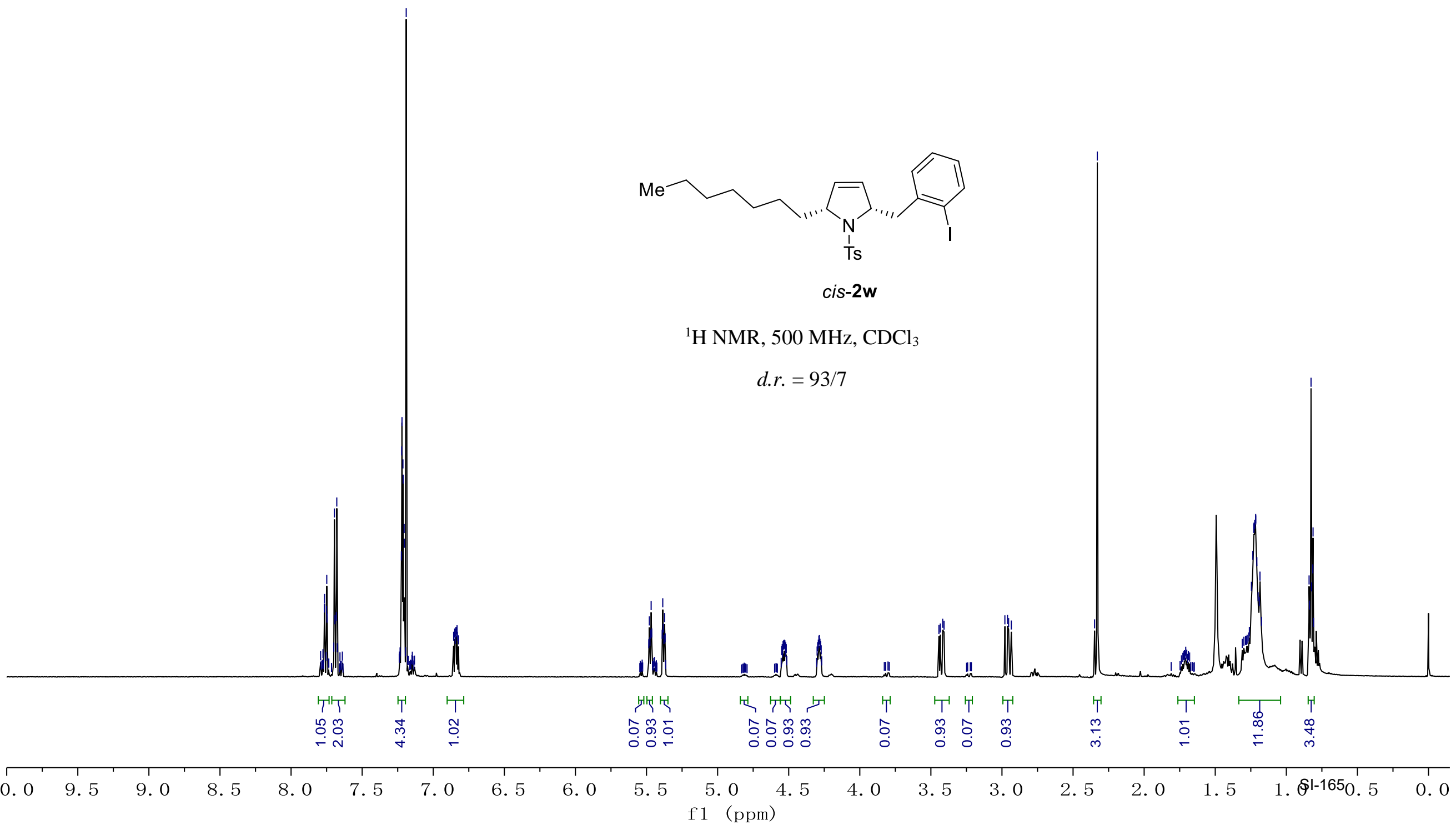


Spectrometer Frequency 100.53

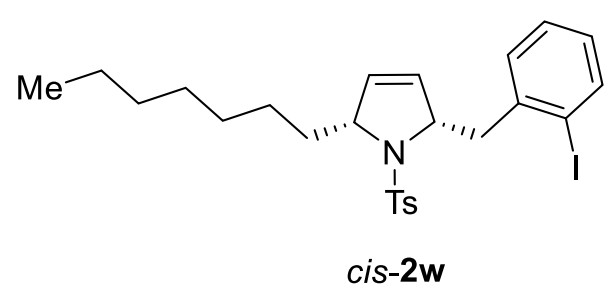

${ }^{13} \mathrm{C}$ NMR, $101 \mathrm{MHz}, \mathrm{CDCl}_{3}$

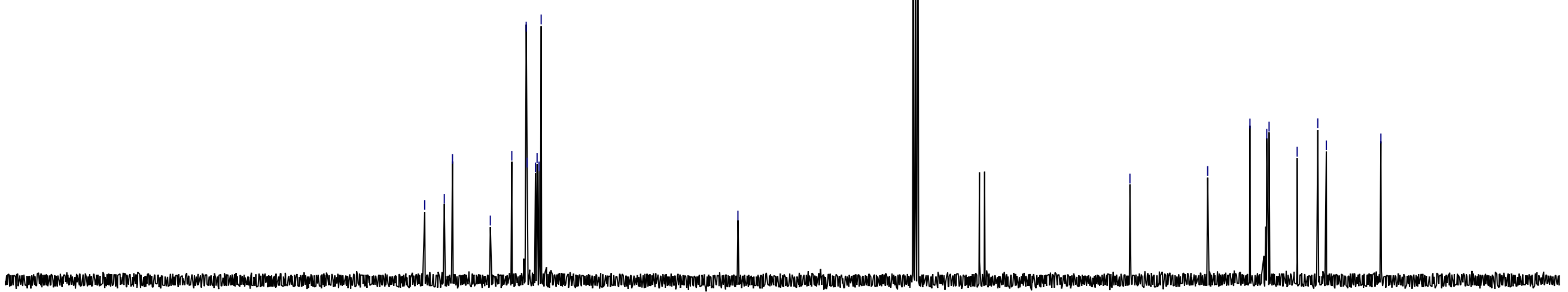

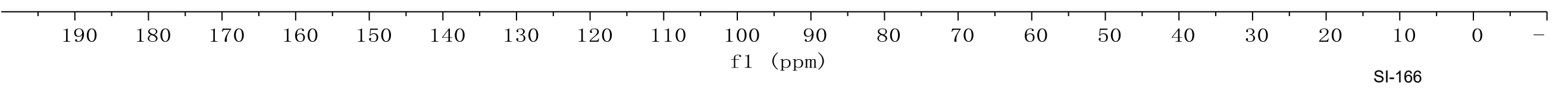




\begin{tabular}{|c|c|}
\hline Parameter & Value \\
\hline Title & cxp-7-78-p-H1 \\
\hline Solvent & $\mathrm{cdcl} 3$ \\
\hline \multicolumn{2}{|c|}{ Spectrometer Frequency599.64 } \\
\hline Nucleus & $1 \mathrm{H}$ \\
\hline
\end{tabular}

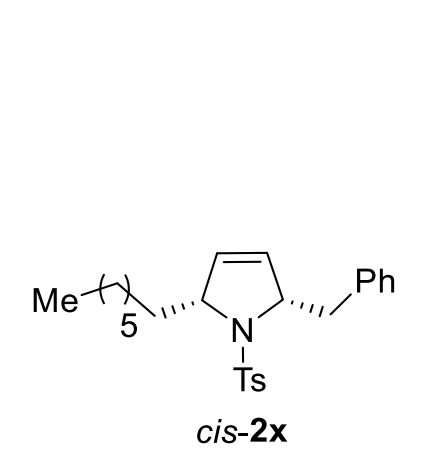

${ }^{1} \mathrm{H} \mathrm{NMR}, 600 \mathrm{MHz}, \mathrm{CDCl}_{3}$

$$
\text { d.r. }=93 / 7
$$

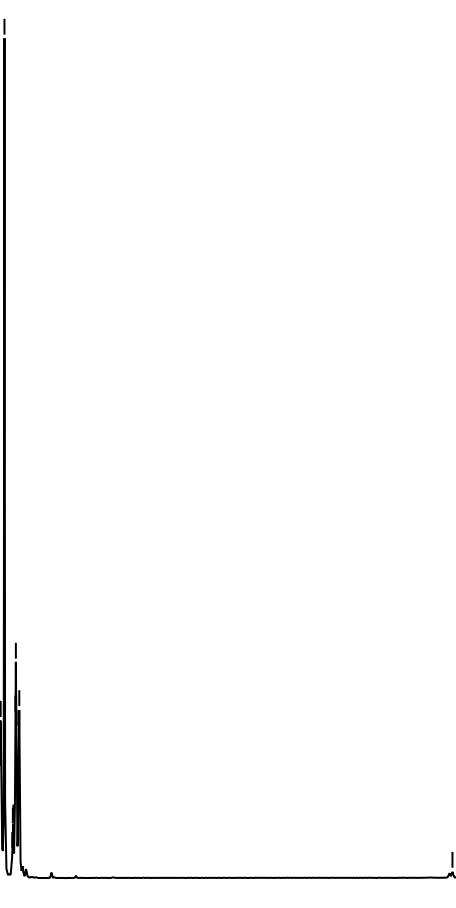

\begin{tabular}{|c|c|c|c|c|c|c|c|c|c|c|c|c|c|c|c|c|c|c|c|c|c|c|}
\hline & & & & & & 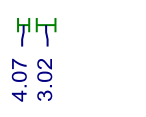 & & & 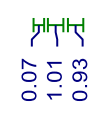 & $\begin{array}{l}1 T \\
\hat{0} \\
0\end{array}$ & $\begin{array}{l}\text { T' } \\
\stackrel{\circ}{\circ}\end{array}$ & $\begin{array}{l}\text { 'T } \\
\infty \\
\stackrel{0}{0} \\
0\end{array}$ & $\begin{array}{l}\text { T' } \\
\hat{0} \\
0\end{array}$ & $\begin{array}{l}T^{\top} \\
\infty \\
0 \\
0 \\
0\end{array}$ & $\begin{array}{l}T \\
\top \\
\infty \\
0 \\
0\end{array}$ & $\begin{array}{ll}T^{\prime} & T \\
\hat{o} & \bar{\rho} \\
0 & \end{array}$ & & $\begin{array}{l}\text { 'T } \\
\stackrel{0}{0} \\
\stackrel{8}{-}\end{array}$ & $\stackrel{\longmapsto}{\stackrel{1}{\rightleftarrows}}$ & $\begin{array}{l}\text { 'T } \\
\tilde{N} \\
\stackrel{\sim}{\infty}\end{array}$ & & \\
\hline 3.0 & 9.5 & 9.0 & 8.5 & 8.0 & 7.5 & 7.0 & 6.5 & 6.0 & 5.5 & $\begin{array}{l}5.0 \\
\mathrm{f1}(\mathrm{ppm})\end{array}$ & 4.5 & 4.0 & & 3.5 & 3.0 & 2.5 & 2.0 & 1.5 & & .0 & 0.5 & 0.0 \\
\hline
\end{tabular}


Solvent $\quad \mathrm{cdcl} 3$

Spectrometer Frequency 125.70

Nucleus

$13 \mathrm{C}$

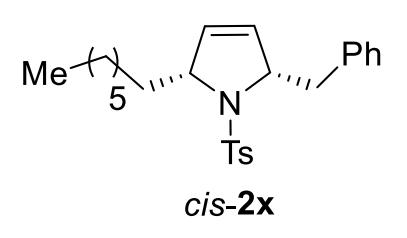

${ }^{13} \mathrm{C} \mathrm{NMR}, 126 \mathrm{MHz}, \mathrm{CDCl}_{3}$

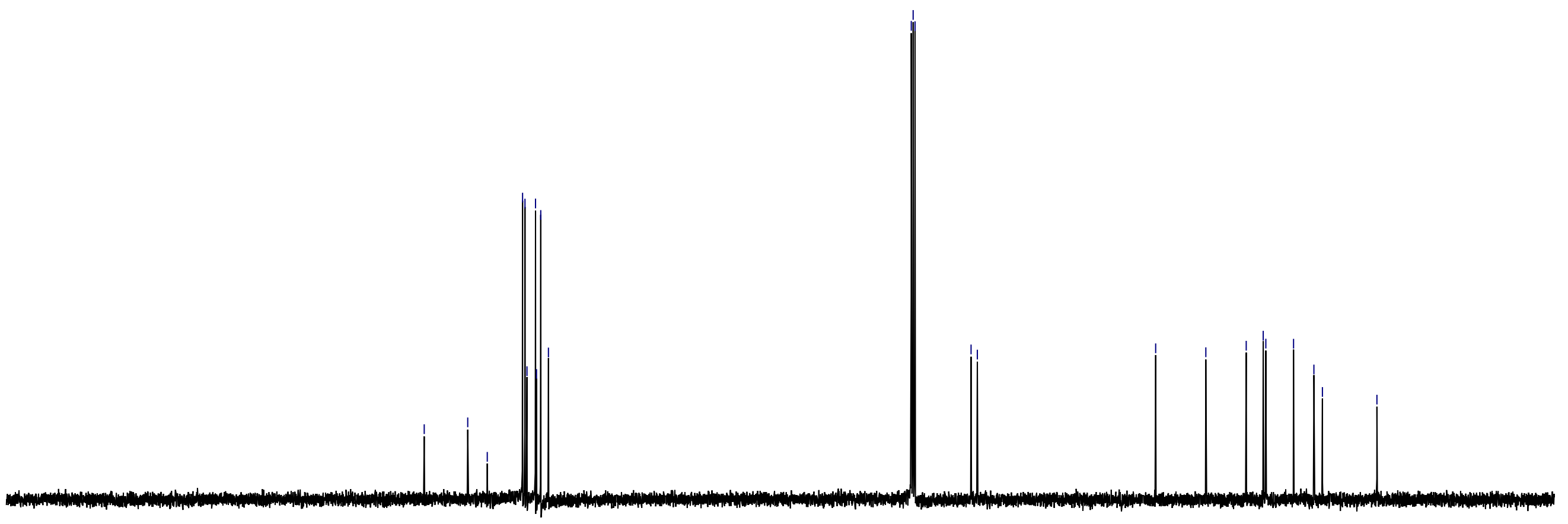

\begin{tabular}{|c|c|c|c|c|c|c|c|c|c|c|c|c|c|c|c|c|c|c|c|}
\hline $200 \quad 190$ & 180 & 170 & 160 & 150 & 140 & 130 & 120 & 110 & $\begin{array}{c}100 \\
\mathrm{f} 1\end{array}$ & $\begin{array}{r}90 \\
(\mathrm{ppm})\end{array}$ & 80 & 70 & 60 & 50 & 40 & 30 & 20 & $\begin{array}{r}10 \\
\text { SI-168 }\end{array}$ & 0 \\
\hline
\end{tabular}




\begin{tabular}{|ll|}
\hline \multicolumn{1}{|c|}{ Parameter } & \multicolumn{1}{c|}{ Value } \\
Title & cxp-7-81-2-p-H1 \\
Solvent & cdc13 \\
Spectrometer Frequency599.64 \\
\hline
\end{tabular}
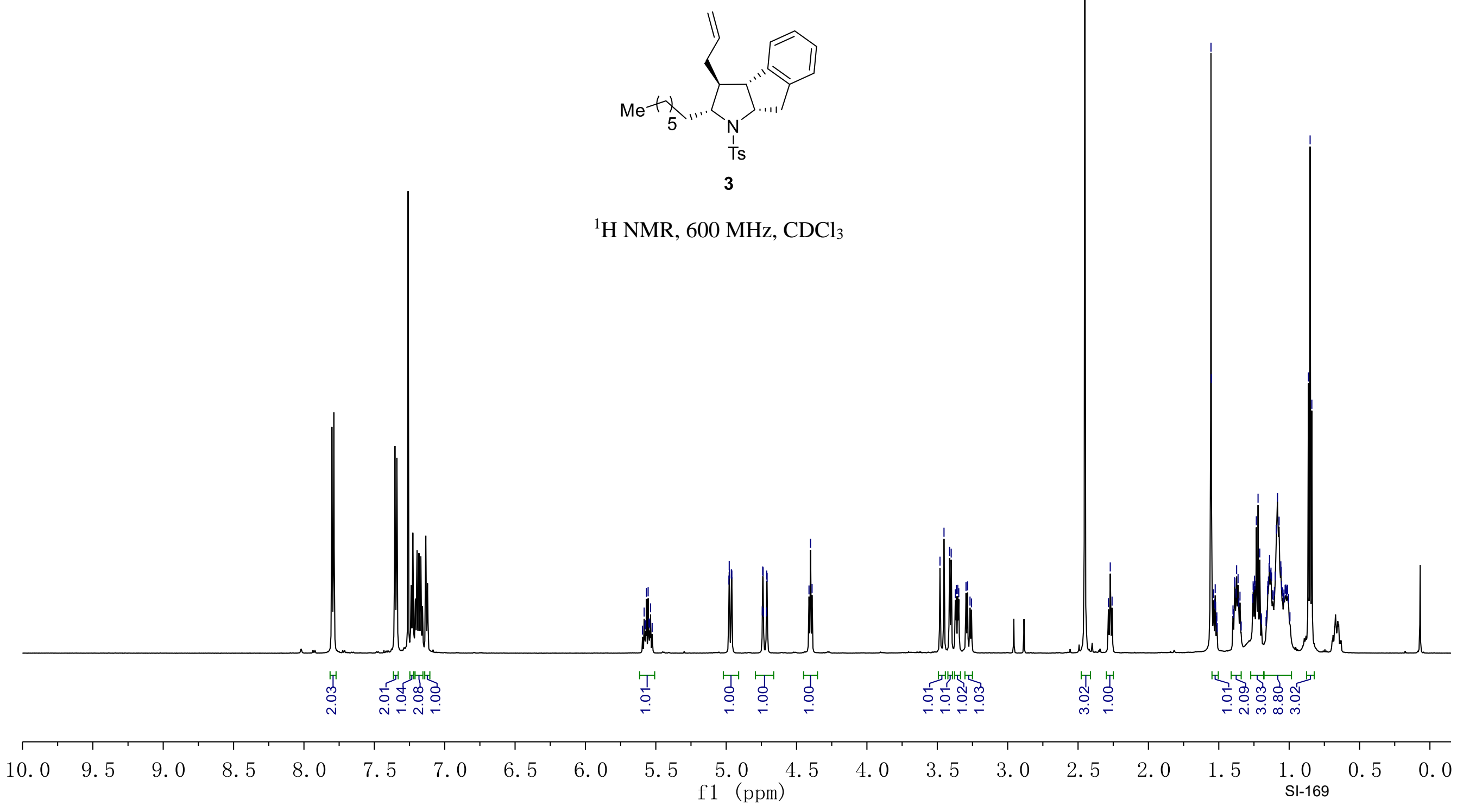


\begin{tabular}{|lc|}
\hline \multicolumn{1}{|c|}{ Parameter } & Value \\
Title & cxp-7-81-2-p-C13 \\
Solvent & cdcl3 \\
Spectrometer Frequency125.70 \\
\hline
\end{tabular}

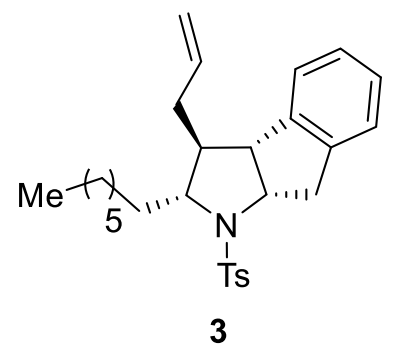

${ }^{13} \mathrm{C} \mathrm{NMR}, 126 \mathrm{MHz}, \mathrm{CDCl}_{3}$
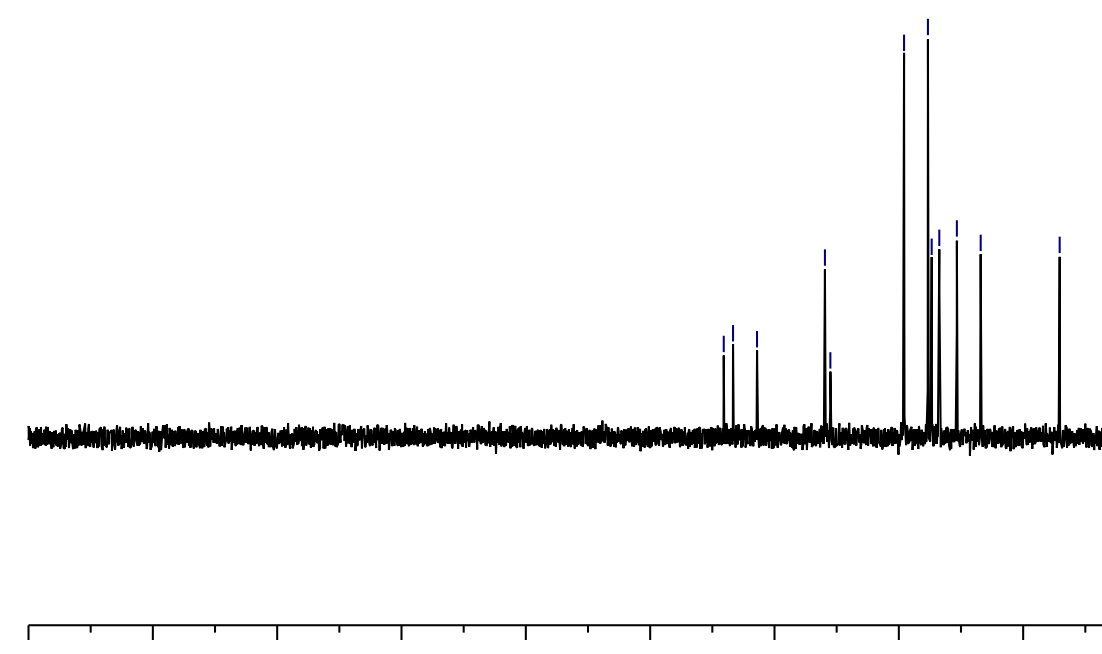


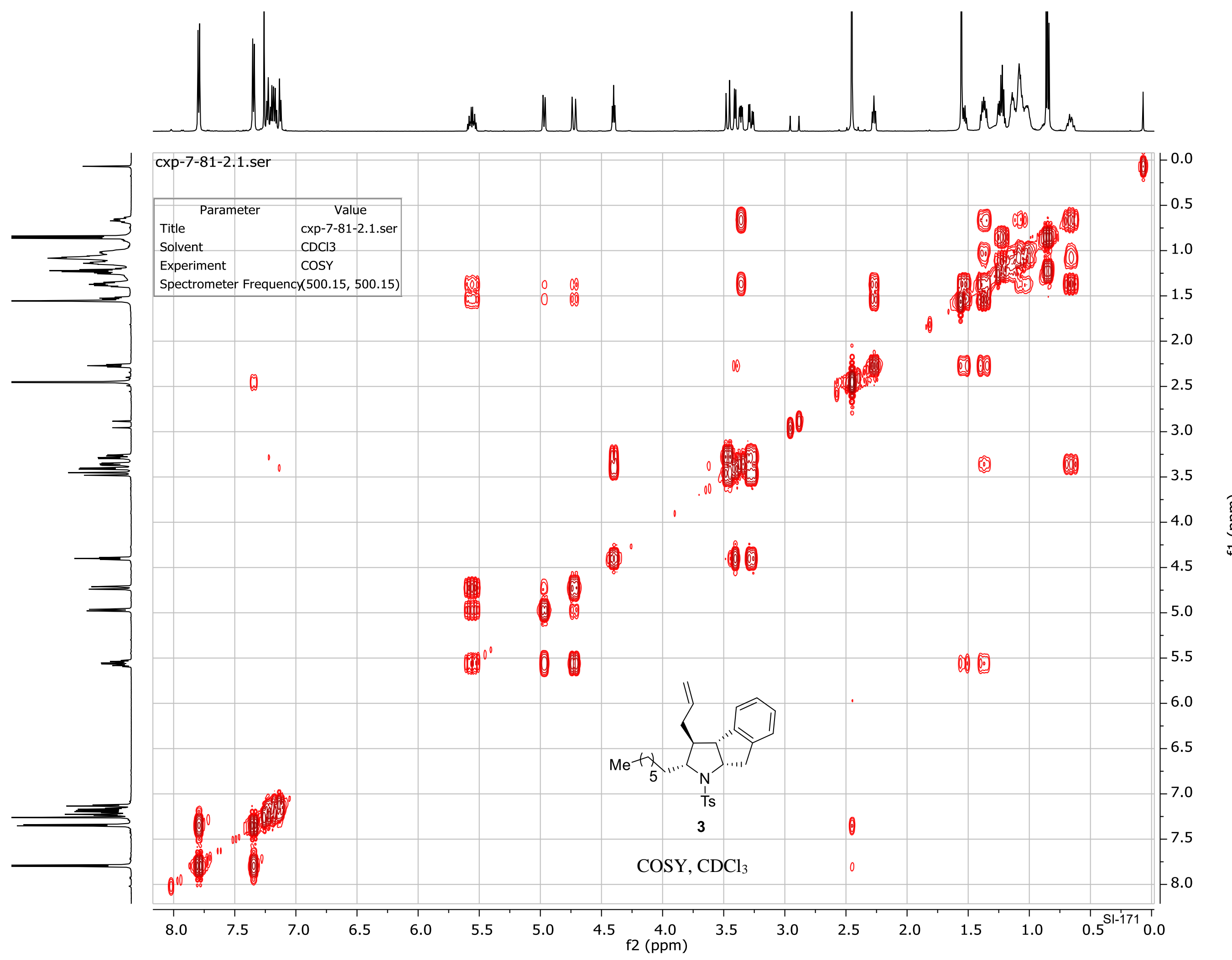




\begin{tabular}{|ll|}
\hline \multicolumn{1}{|c|}{ Parameter } & \multicolumn{1}{c|}{ Value } \\
Title & cxp-6-241-2-3-2.1.fid \\
Solvent & $\mathrm{CDCl3}$ \\
Spectrometer Frequency & 500.15 \\
Nucleus & $1 \mathrm{H}$ \\
\hline
\end{tabular}

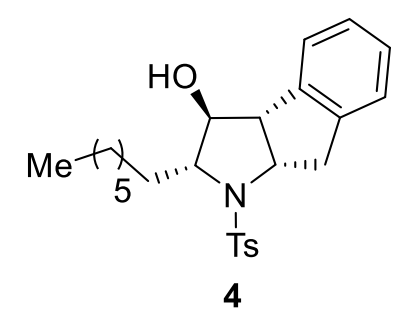

${ }^{1} \mathrm{H}$ NMR, $500 \mathrm{MHz}, \mathrm{CDCl}_{3}$

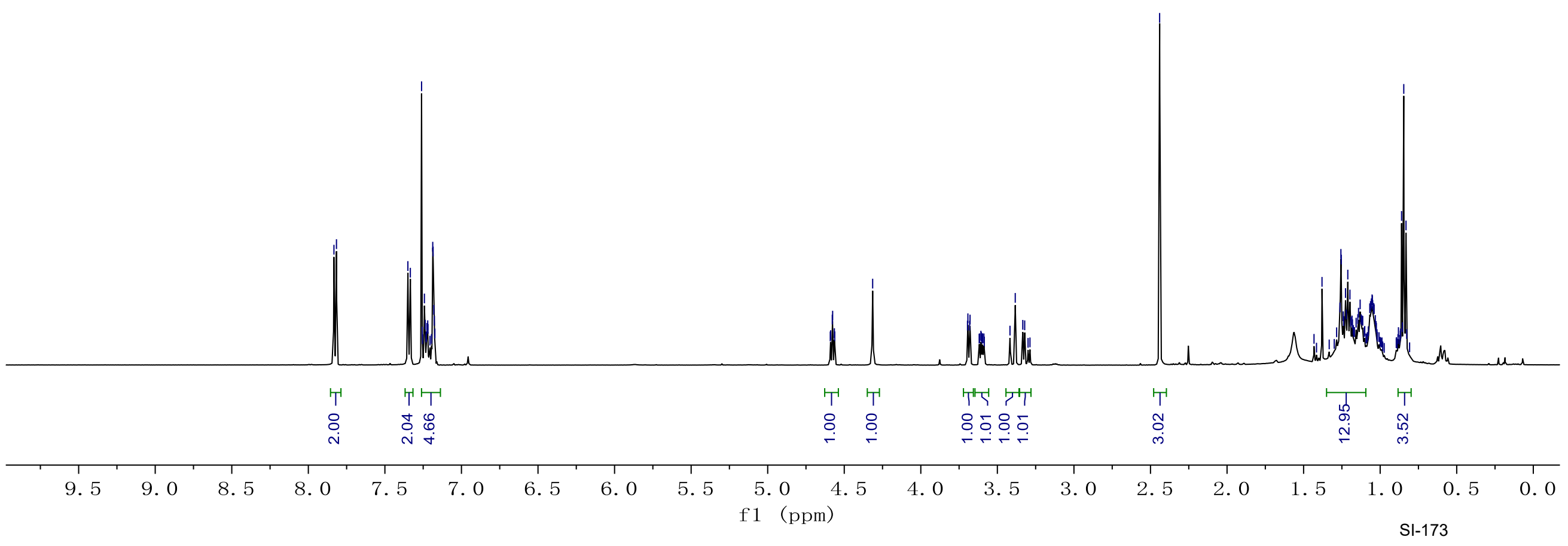


Spectrometer Frequency 125.78

Nucleus

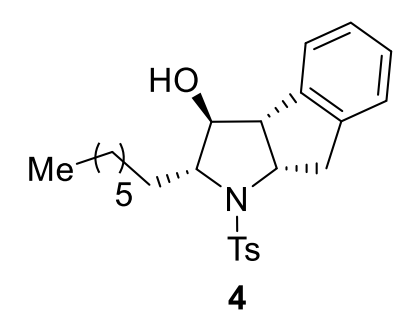

${ }^{13} \mathrm{C} \mathrm{NMR}, 126 \mathrm{MHz}, \mathrm{CDCl}_{3}$

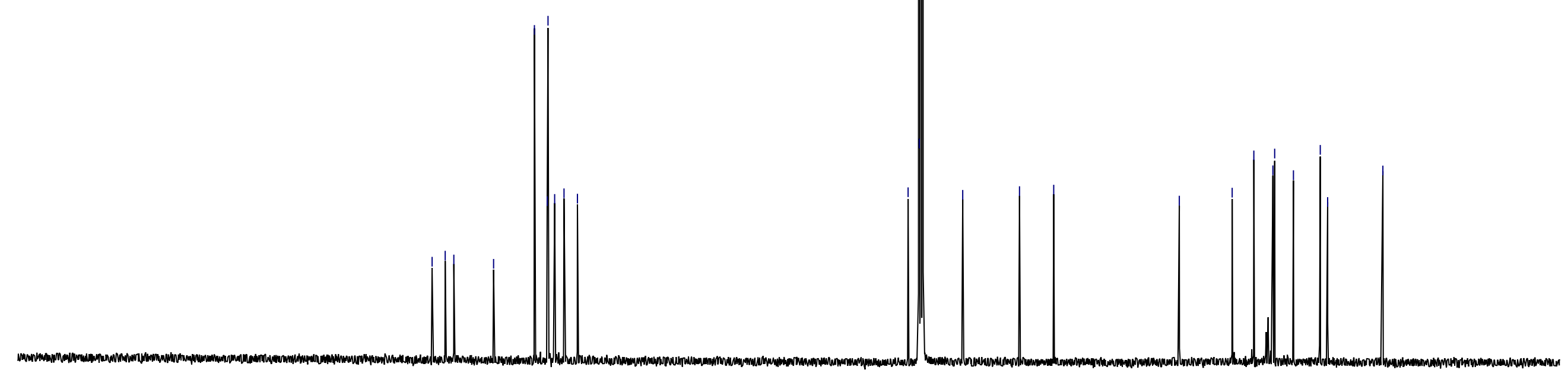




\begin{tabular}{|ll|}
\hline \multicolumn{1}{|c|}{ Parameter } & \multicolumn{1}{c|}{ Value } \\
Title & cxp-7-74-p-H1 \\
Solvent & cdcl3 \\
Spectrometer Frequency599.64 \\
\hline
\end{tabular}

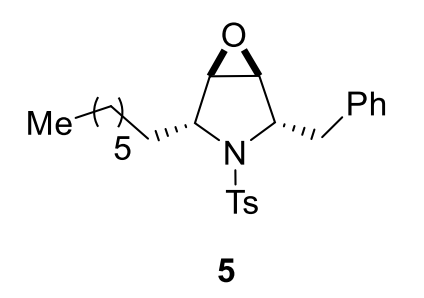

${ }^{1} \mathrm{H} \mathrm{NMR}, 600 \mathrm{MHz}, \mathrm{CDCl}_{3}$

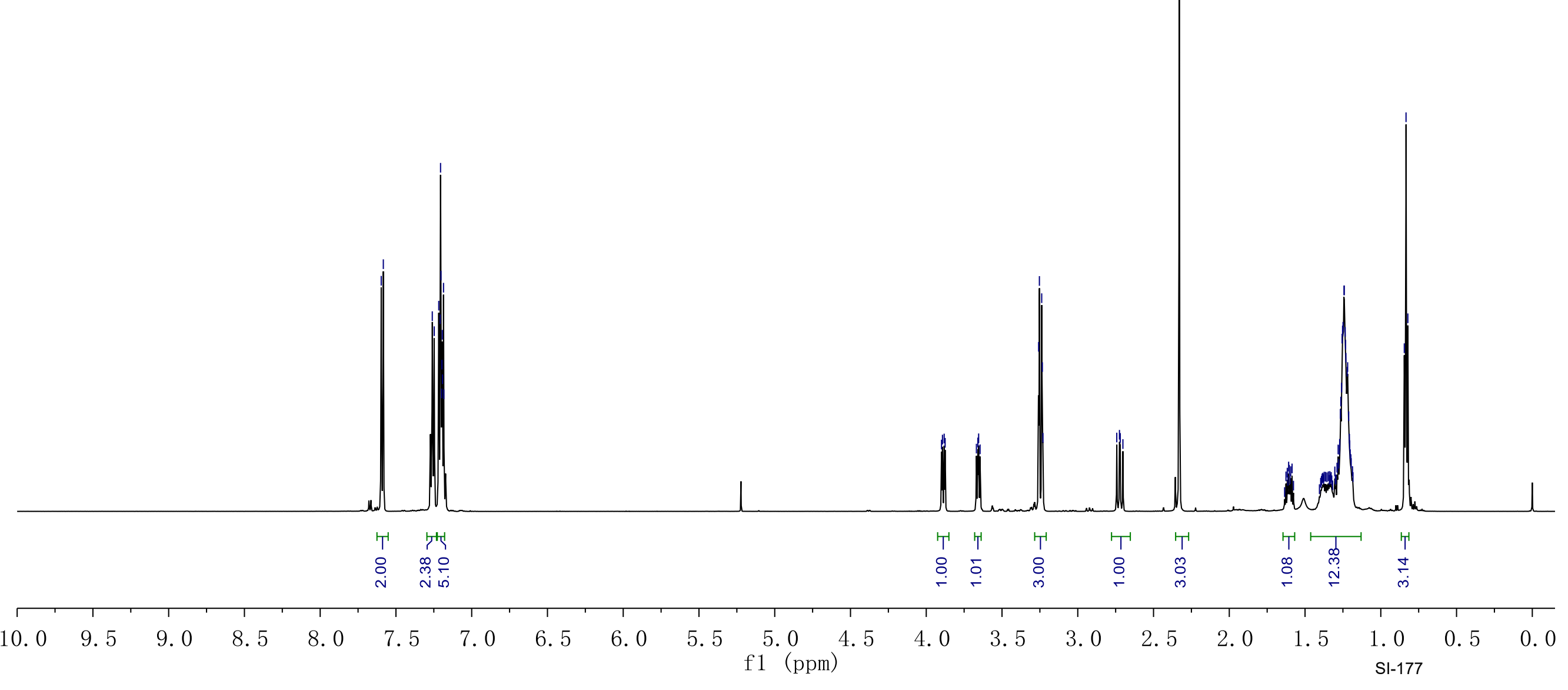




\begin{tabular}{|lc|}
\hline \multicolumn{1}{|c|}{ Parameter } & Value \\
Title & cxp-7-74-p.3.fid \\
Solvent & $\mathrm{CDCl3}$ \\
Spectrometer Frequency 100.62 \\
Nucleus & $13 \mathrm{C}$
\end{tabular}

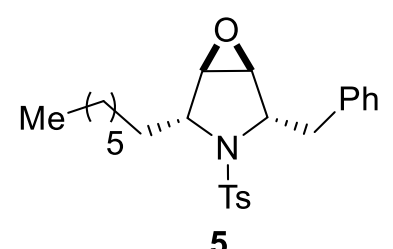

${ }^{13} \mathrm{C}$ NMR, $101 \mathrm{MHz}, \mathrm{CDCl}_{3}$

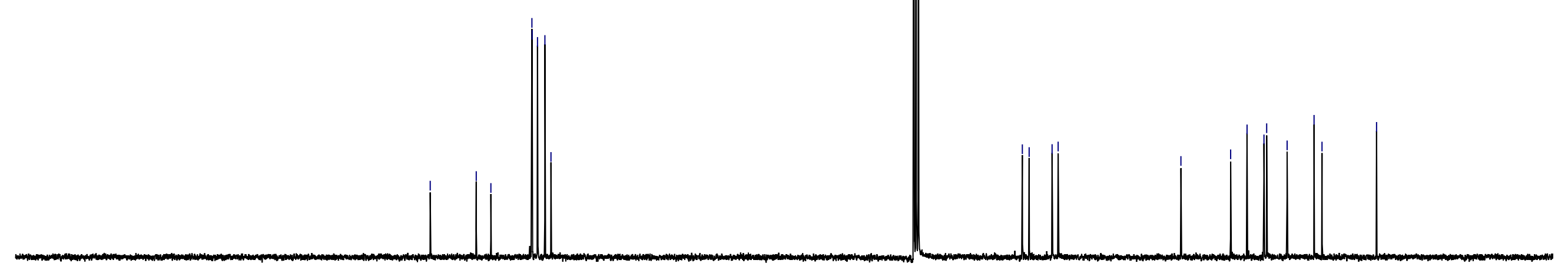

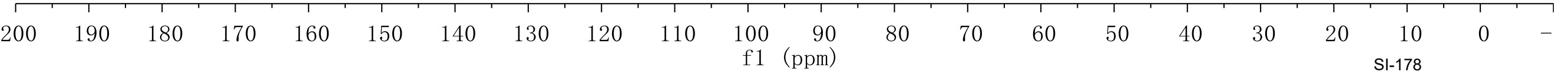




\begin{tabular}{|lc|}
\hline \multicolumn{1}{|c|}{ Parameter } & \multicolumn{1}{c|}{ Value } \\
Title & cxp-7-88-p-H1 \\
Solvent & cdcl3 \\
Spectrometer Frequency599.64 \\
\hline
\end{tabular}

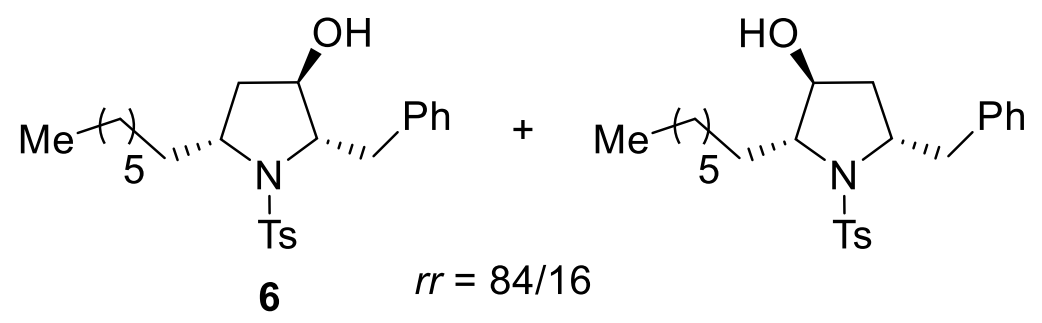

${ }^{1} \mathrm{H} \mathrm{NMR}, 600 \mathrm{MHz}, \mathrm{CDCl}_{3}$

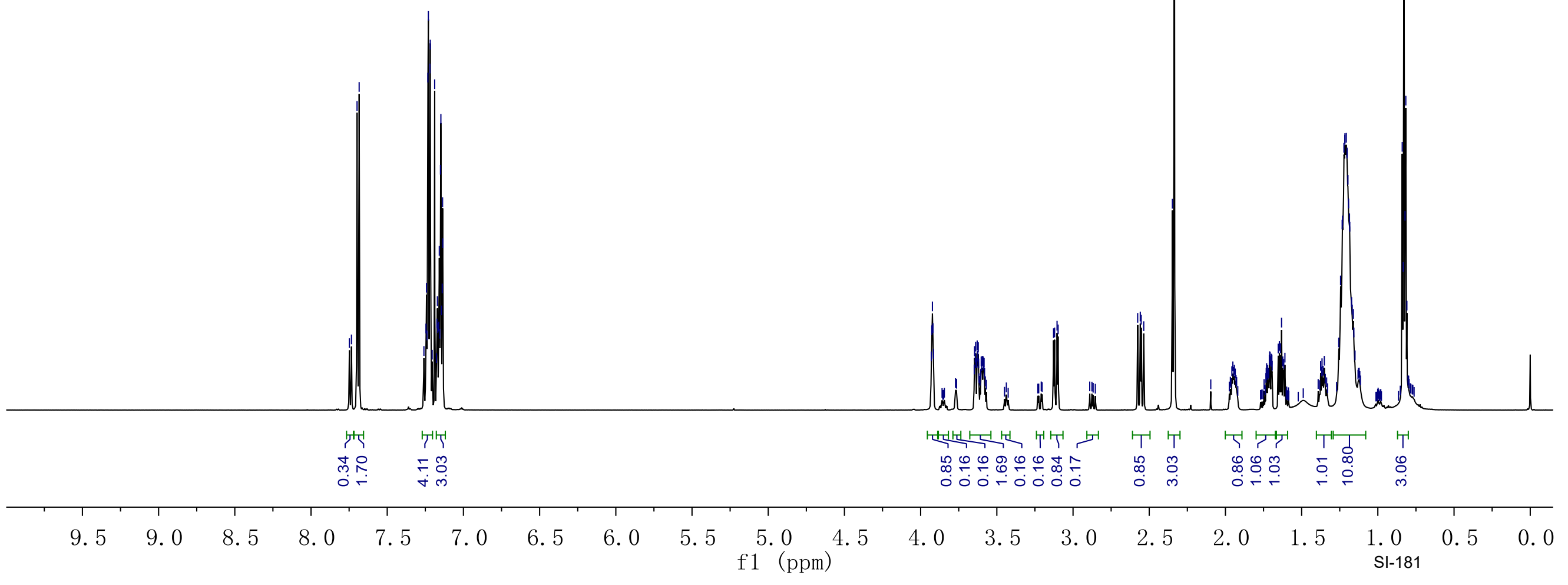




\begin{tabular}{|lc|}
\hline \multicolumn{1}{|c|}{ Parameter } & \multicolumn{1}{c|}{ Value } \\
Title & Cxp-7-88.1.fid \\
Solvent & CDCl3 \\
Spectrometer Frequency125.78
\end{tabular}

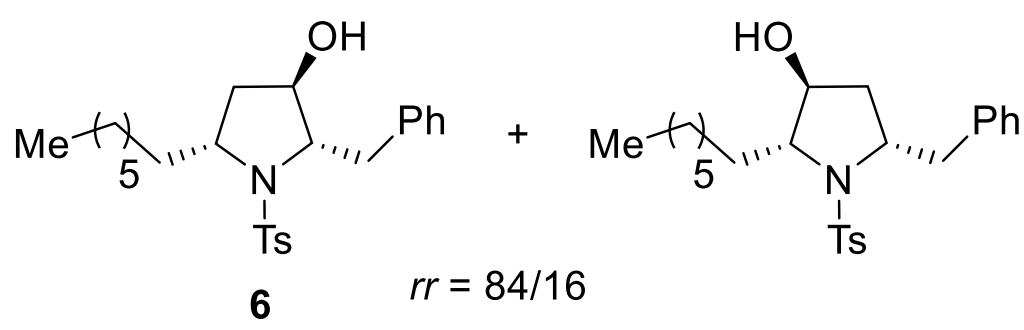

${ }^{13} \mathrm{C} \mathrm{NMR}, 126 \mathrm{MHz}, \mathrm{CDCl}_{3}$
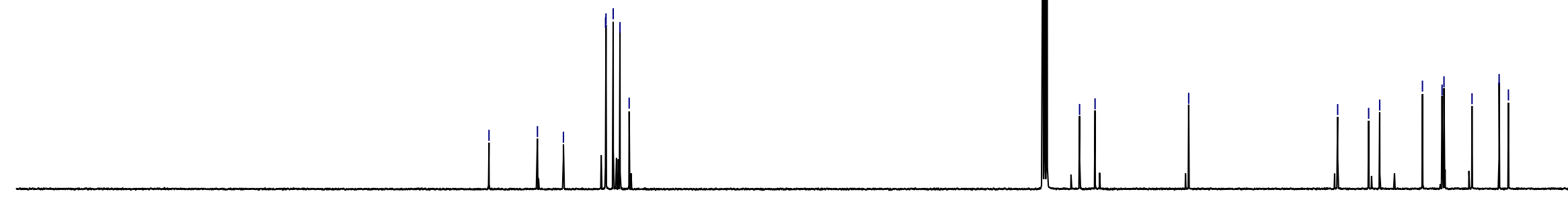

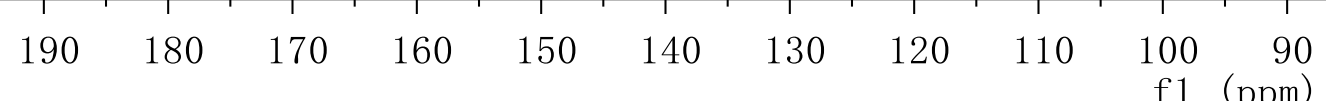

80

70

60

50

40

30

20

10 


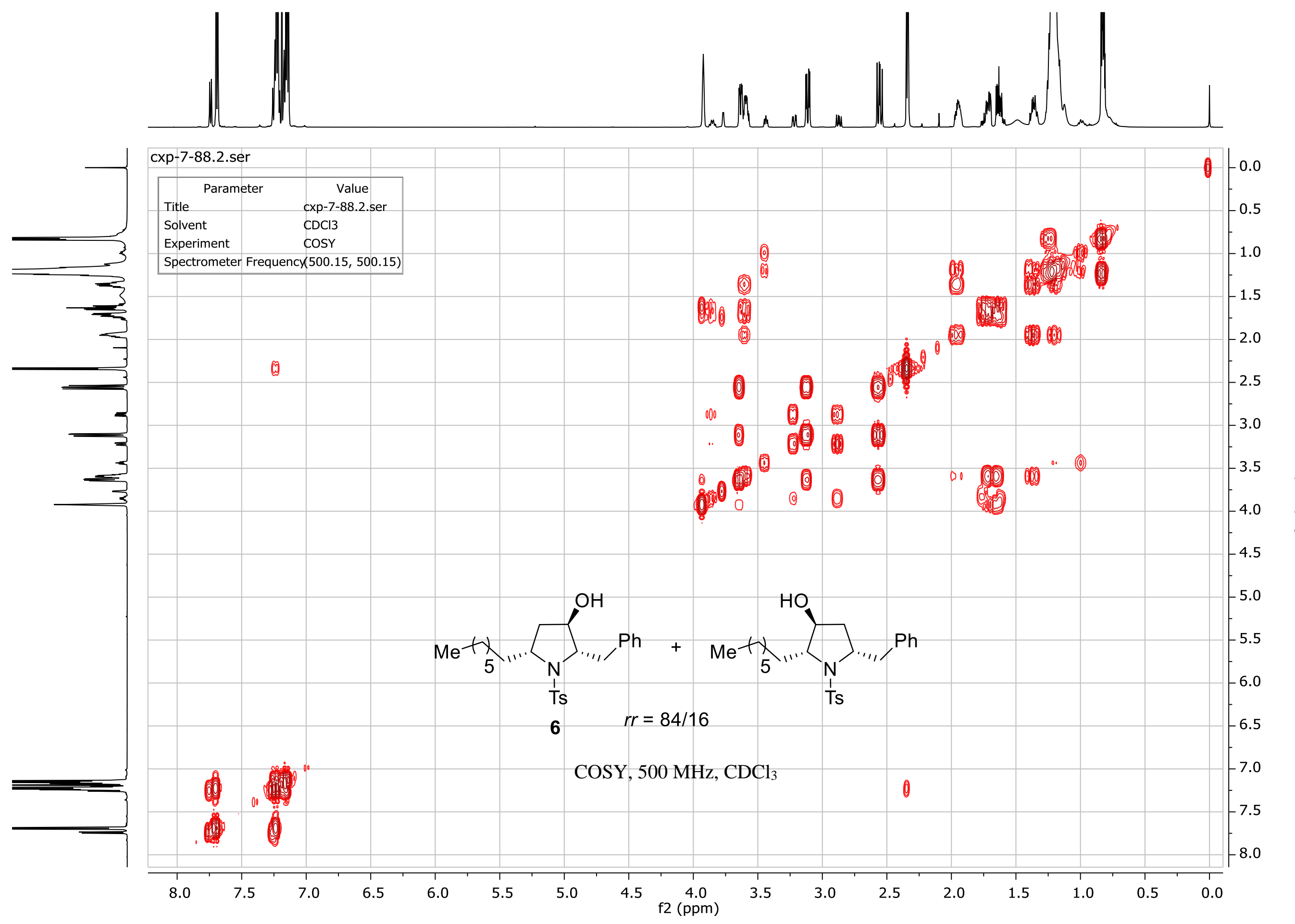




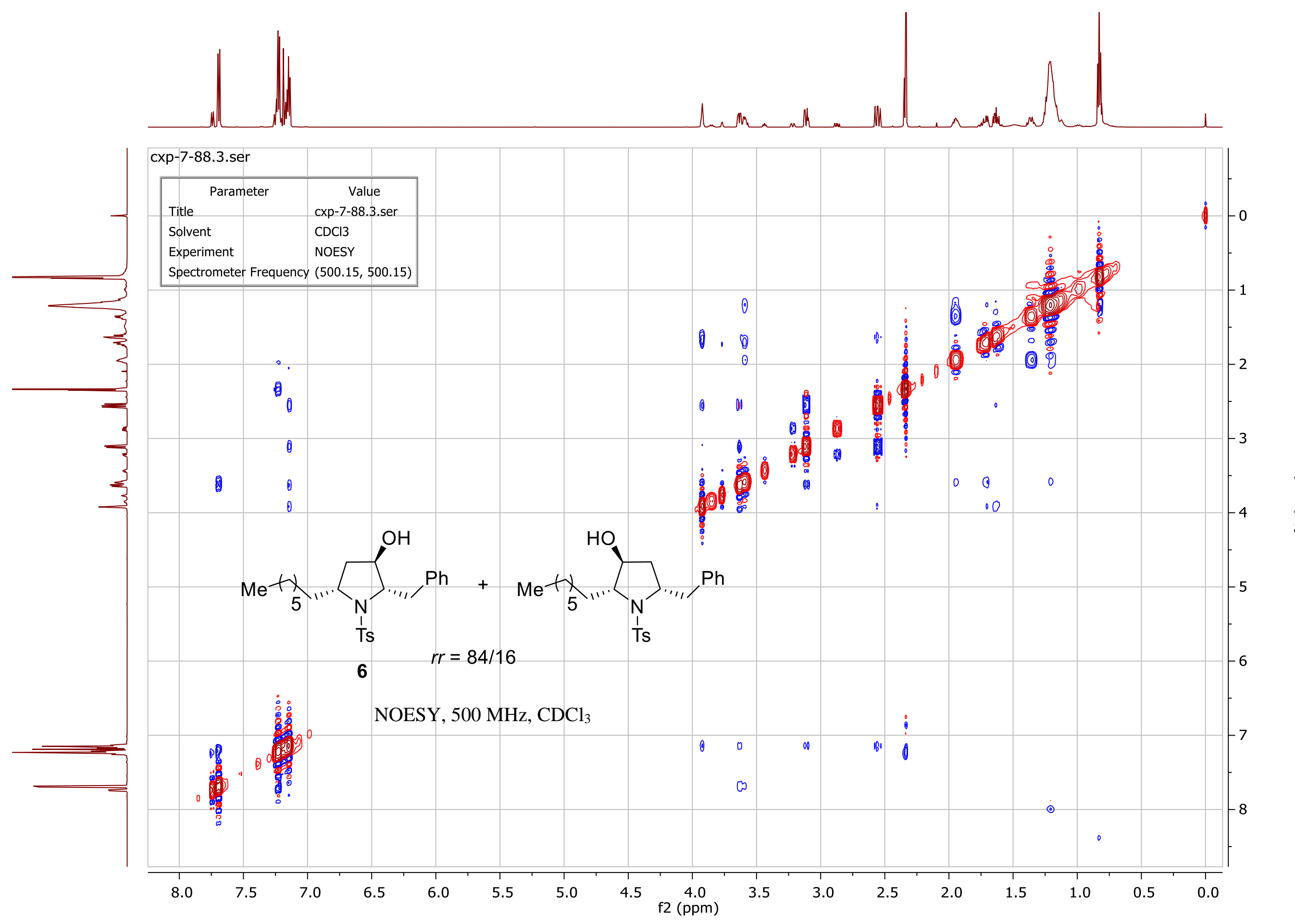




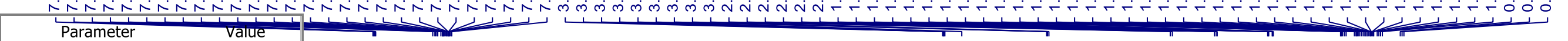

\section{Title}

cxp-7-92-p-H1

Solvent $\mathrm{cdcl} 3$

Spectrometer Frequency 599.64

Nucleus

$1 \mathrm{H}$

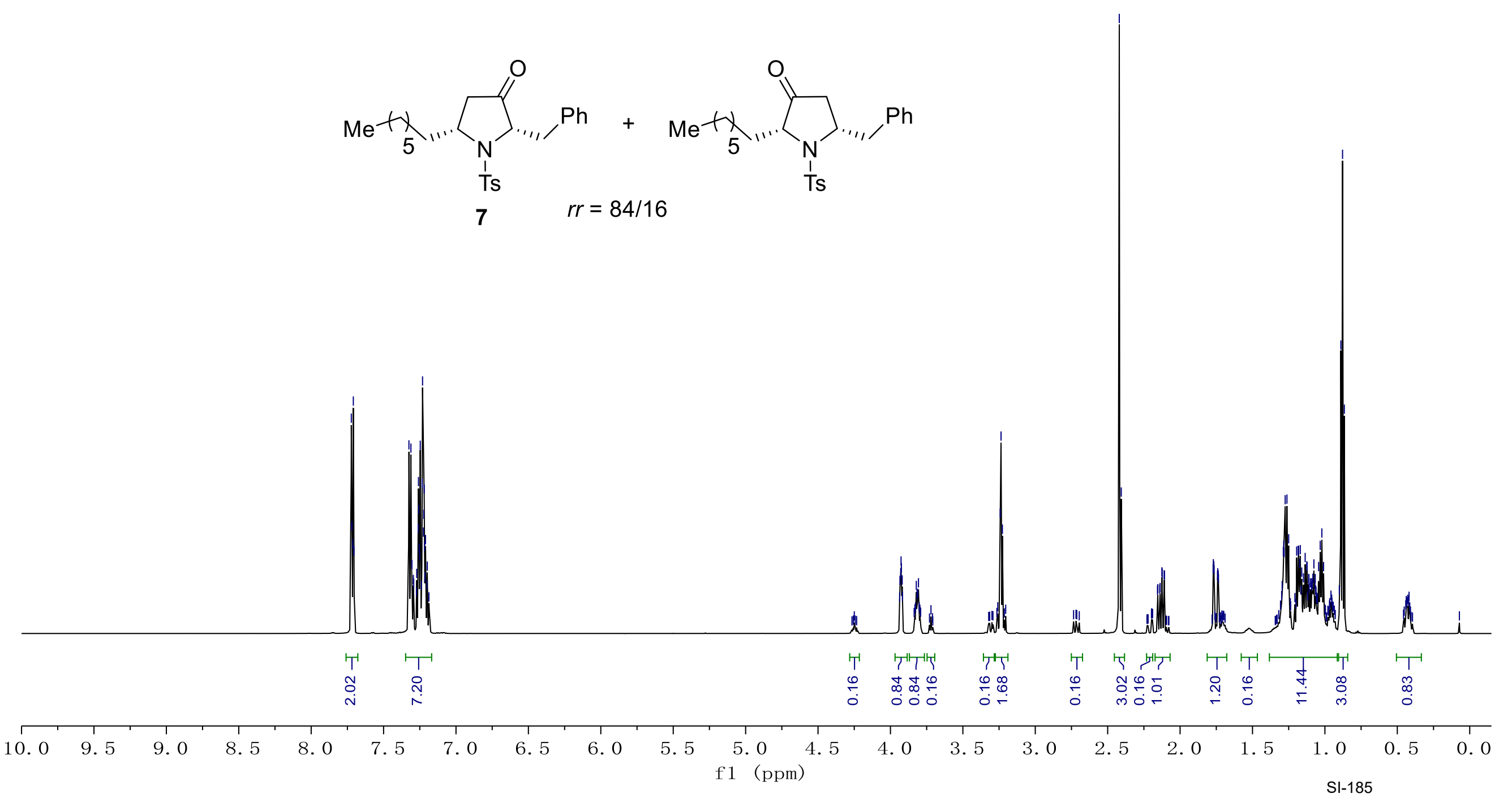




\section{Title}

cxp-7-92-p-H1 (1).fid.1.fid

Solvent

Experiment

$\mathrm{CDCl} 3$

Spectrometer Frequency 125.78

Nucleus

$13 \mathrm{C}$
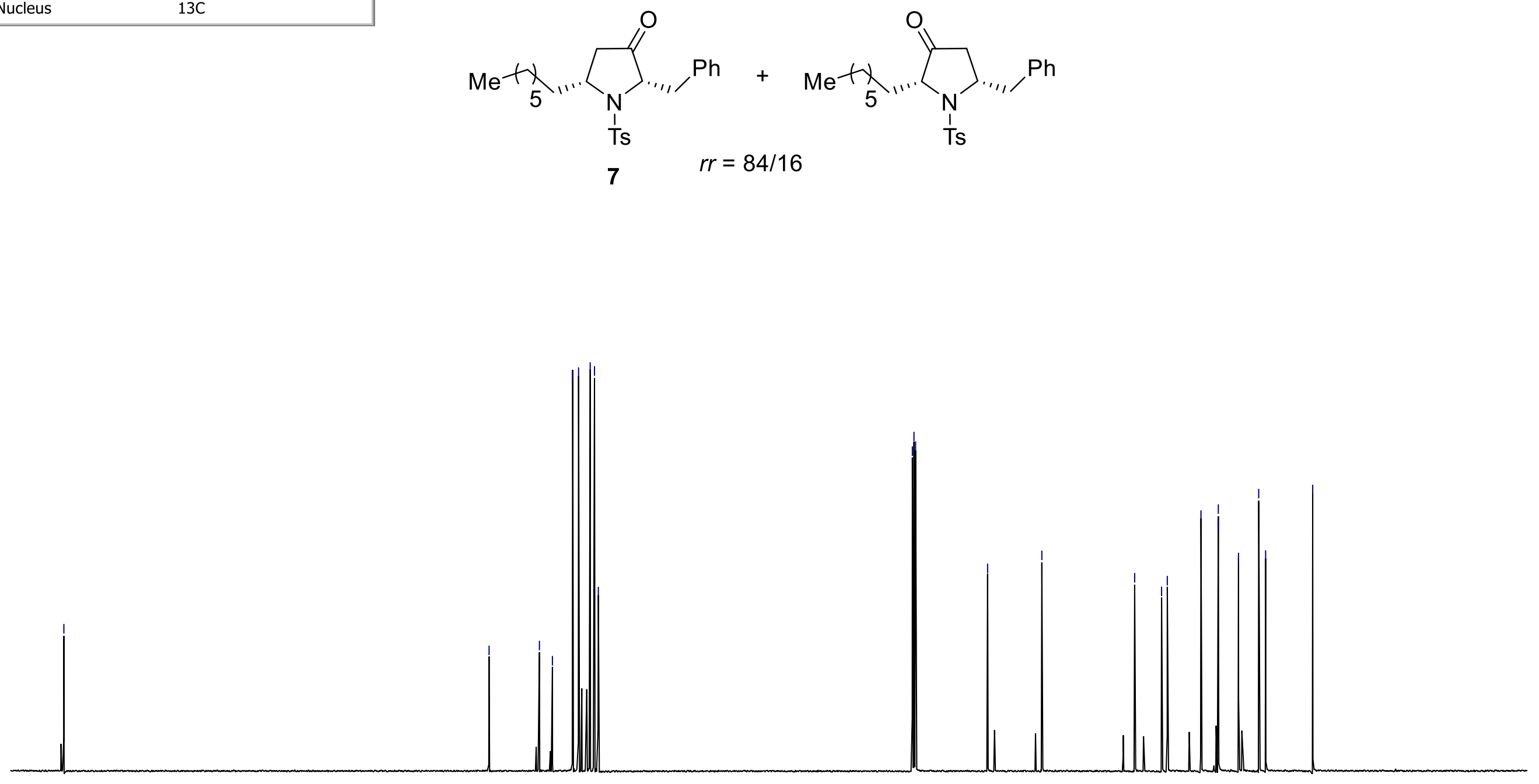

210

200

190180

170

160

150

140

130

120

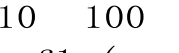

f1 (ppm)

80

70

60

50

40

30

20

10 SI-186 


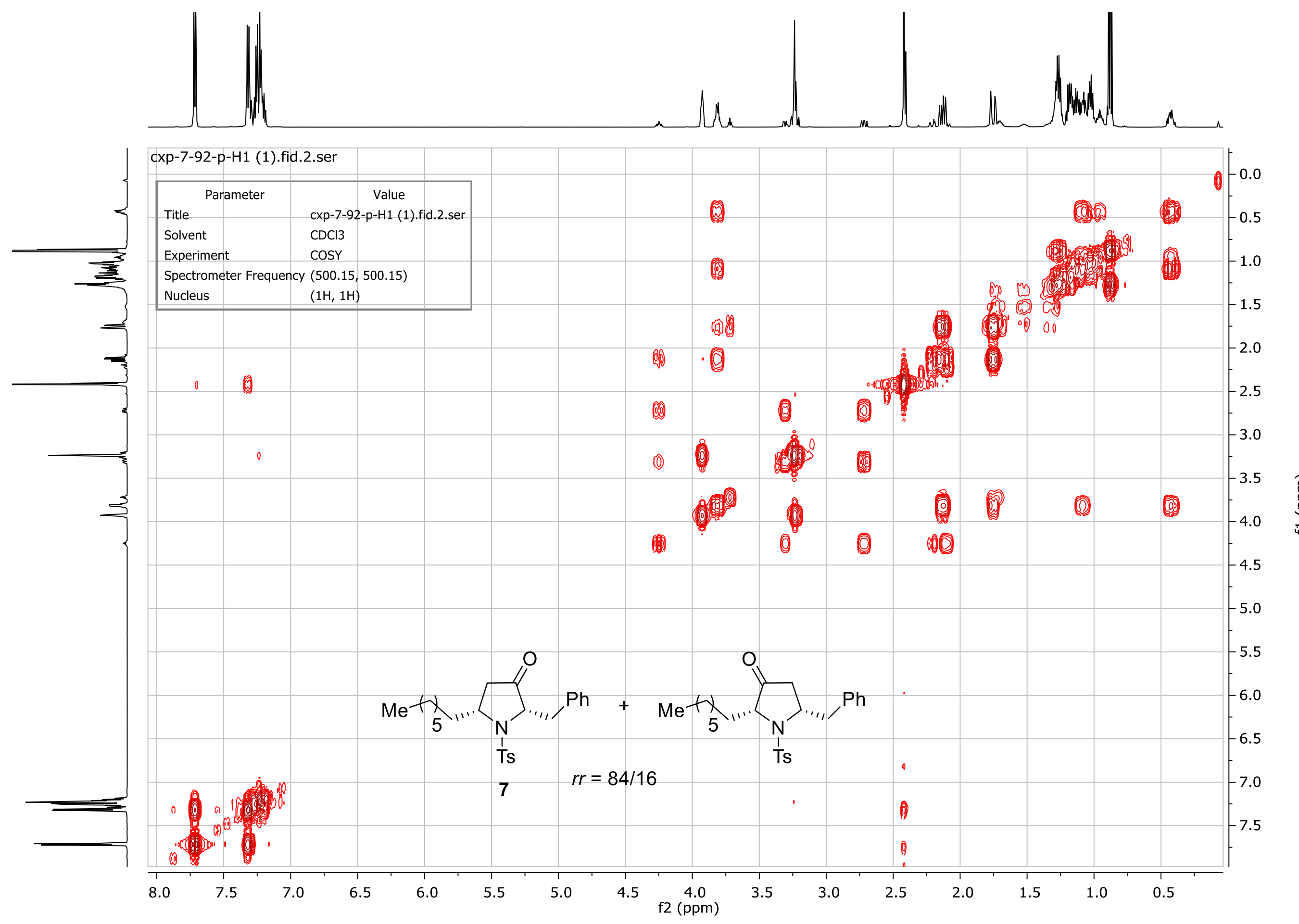

